UNIVERSIDADE DE SÃO PAULO

FACULDADE DE FILOSOFIA, LETRAS E CIÊNCIAS HUMANAS

DEPARTAMENTO DE LETRAS CLÁSSICAS E VERNÁCULAS

PROGRAMA DE PÓS-GRADUAÇÃO EM LITERATURA BRASILEIRA

À procura de objetos gritantes: um estudo da narrativa de Clarice Lispector

Joelma Santana Siqueira

São Paulo

2008 
UNIVERSIDADE DE SÃO PAULO

FACULDADE DE FILOSOFIA, LETRAS E CIÊNCIAS HUMANAS

DEPARTAMENTO DE LETRAS CLÁSSICAS E VERNÁCULAS

PROGRAMA DE PÓS-GRADUAÇÃO EM LITERATURA BRASILEIRA

\section{À procura de objetos gritantes: um estudo da narrativa de Clarice} Lispector

Joelma Santana Siqueira

Tese apresentada ao Programa de Pós-Graduação em Literatura Brasileira do Departamento de Letras Clássicas e Vernáculas da Faculdade de Filosofia, Letras e Ciências Humanas da Universidade de São Paulo, para obtenção do título de Doutor em Letras.

Orientador: Prof. Dr. José Miguel Wisnik.

São Paulo

2008 
Para meus pais:

Feliciano (em memória) e Ana Maria. 


\section{AGRADECIMENTOS}

Ao professor José Miguel Wisnik, pela orientação generosa, que nos permitiu ver e ouvir juntos a narrativa clariciana.

Ao colegiado do Departamento de Letras da Universidade Federal de Viçosa, pelo apoio e pela aprovação da licença que possibilitou o período de dedicação exclusiva à pesquisa.

À Pró-Reitoria de Pesquisa e Pós-Graduação da Universidade Federal de Viçosa, em especial, às funcionárias Margarida e Suely, pelo serviço eficaz e atencioso.

À Fundação Arthur Bernardes, pela bolsa que viabilizou minha permanência na cidade de São Paulo durante o período de dedicação exclusiva à pesquisa.

Aos professores Jaime Ginzburg e João Adolfo Hansen, pela leitura atenta do relatório de qualificação, da qual decorreram sugestões importantes para o andamento da pesquisa.

À Fundação Casa de Rui Barbosa, pelo atendimento prestado aos pesquisadores do Arquivo-Museu de Literatura Brasileira.

Ao professor Cyro del Nero, pela conversa agradável sobre seu trabalho de ilustração para a obra Laços de família.

Aos funcionários do Programa de Pós-Graduação em Literatura Brasileira da Faculdade de Filosofia, Letras e Ciências Humanas da Universidade de São Paulo, pelo atendimento eficaz.

Ao professor Rodrigo Naves, que em seu curso livre encontrou um modo honesto de compartilhar sua visão sobre as artes.

À Maria Rita Marinho, da Fundação Bienal de São Paulo, pelo atendimento ágil e atencioso.

Aos amigos com quem compartilhei dúvidas e idéias referentes à realização do trabalho:

Elaine Cavalcante Gomes, Elaine Cristina Cintra, Luiz Fernando Reis, Joelice, Júlio Galharte, Keila Málaque e Alice Jham. E aos amigos que me dedicaram apoios imprescindíveis: Karine Siqueira, Ivana Rossi, João Sandim, Ceila Málaque, Christianne Rochebois, Elisa Lopes, Cristiane Cataldi e Nazaré Molica.

Ao amigo Jorge de Lima, por seu inestimável trabalho de revisão e formatação.

Ao Cacado e às nossas famílias, pelo cuidado de todo dia. 


\section{RESUMO}

O presente trabalho detém-se na leitura de textos da escritora Clarice Lispector produzidos nos anos 1940, 1950 e 1960: Perto do coração selvagem, contos de Laços de família e textos e contos de A legião estrangeira. Com a finalidade de investigar inter-relações entre literatura e outras artes na obra da escritora, o corpus foi confrontado com textos sobre as fontes e tradições da arte moderna, trabalhos críticos sobre a arte moderna no Brasil e estudos sobre o espaço moderno. A partir do conceito de "espaço polissensorial", proposto por Pierre Francastel, e do conceito de "espaço em obra", proposto por Alberto Tassinari, buscamos discutir homologias estruturais entre $\mathrm{o}$ espaço da narrativa clariciana e o espaço da pintura moderna. Os dois conceitos se relacionam a duas funções complementares que pensamos existir nas narrativas estudadas: a figuração e a exposição. Pela primeira, a narrativa apresenta personagens, ações, acontecimentos, eventos etc; e pela segunda, apresenta sinais do fazer. O pintor Wassily Kandinsky escreveu que o artista criador busca na aproximação com a música, a mais imaterial de todas as artes, um modo de exprimir com seus próprios meios sem que a imitação seja um fim em si. Trata-se de um aspecto observável na narradora de Perto do coração selvagem, por isso procuramos discutir de que modo a música, aludida muitas vezes na narrativa, relaciona-se com a estrutura do romance.

\section{PALAVRAS-CHAVE:}

Literatura e outras artes; Arte moderna; Narrativa moderna; Espaço moderno; Clarice Lispector. 


\begin{abstract}
This work is focused on readings of Clarice Lispector's writings produced in the 1940s, 1950s and 1960s: the novel Perto do coração selvagem, short stories in Laços de familia and texts and short stories in A legião estrangeira. Aiming at investigating the inter relations between literature and other forms of art, the writer's work corpus was confronted with texts on modern art's sources and traditions, Brazilian modern art critique and modern space studies. Based on the concepts of "polysensorial space" proposed by Pierre Francastel, and "space at work", proposed by Alberto Tassinari, structural homologies were studied between Ms. Lispector's narrative space and that of modern painting. The two concepts are related to two complementary functions which we believe exist in the narratives analyzed: figuration and exposition. The former introduces characters, actions, events, etc...in the narrative; the latter presents signs of acting. The painter Wassily Kandinsky wrote that the artist seeks to find in music, the most immaterial among the arts, a form of self-expression, without imitation being an end in itself. Since this is an aspect observed in the narrator of Perto do coração selvagem, we have attempted to discuss in which ways music, often alluded to in the narrative, is related to the novel's structure.
\end{abstract}

\title{
KEYWORDS:
}

Literature and other arts; Modern art; Modern narrative; Modern space; Clarice Lispector. 


\section{LISTA DE ILUSTRAÇÕES}

Santa Rosa - Ilustração do conto "O jantar" ............................................. 11

Cyro del Nero - Ilustração do conto "O jantar"................................................... 12

0

Cyro del Nero - Ilustração do conto "Devaneio e embriaguez duma rapariga".. 14

Pablo Picasso $\quad$ - Nu arrumando o cabelo.......................................................... 14

Pablo Picasso $\quad$ - Mulher com leque................................................................. 15

Paul Klee

- Paisagem com pássaros amarelos. 


\section{LISTA DE ABREVIAÇÕES}

$\begin{array}{ll}\text { PCS } & \text { Perto do coração selvagem. } \\ \text { LF } & \text { Laços de Famillia. } \\ \text { ME } & \text { A Maçã no escuro. } \\ \text { PSGH } & \text { A paixão segundo G.H. } \\ \text { LE } & \text { A legião estrangeira. } \\ \text { AV } & \text { Água Viva } . \\ \text { OEN } & \text { Onde estivestes de noite? } \\ \text { S } & \text { Seleta. } \\ \text { SV } & \text { Um sopro de vida. } \\ \text { DM } & \text { A descoberta do mundo. } \\ \text { OE } & \text { Outros escritos. } \\ \text { E } & \text { Entrevistas. }\end{array}$




\section{SUMÁRIO}

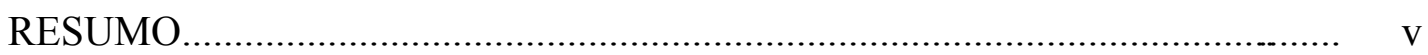

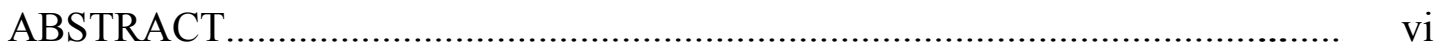

LISTA DE ILUSTRAÇÕES...................................................................... vii

LISTA DE ABREVIAÇÕES.................................................................... viii

INTRODUÇÃ O ................................................................................ 10

1. A LITERATURA E OUTRAS ARTES NA MODERNIDADE........................ 28

2. O ESPAÇO NA ARTE MODERNA............................................................. 48

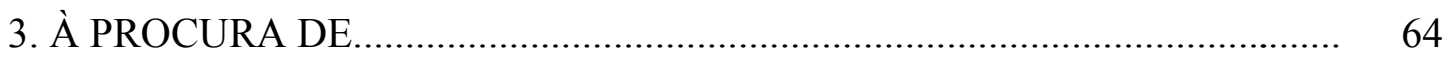

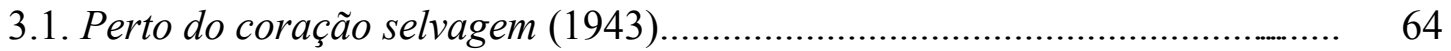

3.2. Laços de família (1960).................................................................................... 107

3.2.1. "O jantar" ............................................................................................... 113

3.2.2. "Devaneio e embriaguez duma rapariga"............................................... 131

3.3. A legião estrangeira (1964).................................................................... 156

3.3.1. "Fundo de gaveta"............................................................................. 159

3.3.2. "Gastão Manoel Henrique”......................................................................... 160

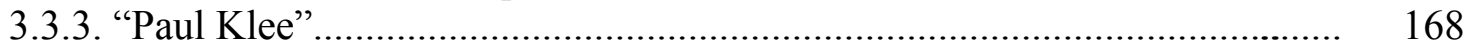

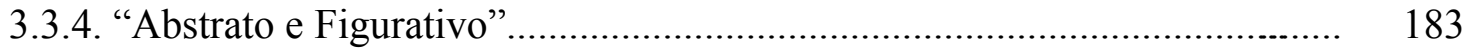

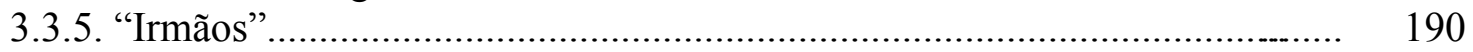

3.3.6. "Uma porta abstrata".............................................................................. 195

3.3.7. "Os desastres de Sofia"............................................................................. 201

3.3.6. "O ovo e a galinha"'.............................................................................. 209

CONSIDERAÇÕES FINAIS......................................................................... 225

REFERÊNCIA BIBLIOGRÁFICA................................................................. 227

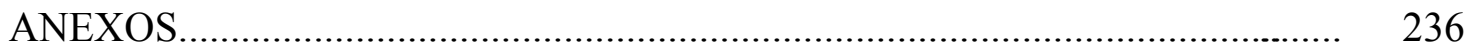




\section{INTRODUÇÃO}

Em O drama da linguagem, Benedito Nunes (1989, p.15) revê textos publicados sob o título Leitura de Clarice Lispector (1973) e realiza, a partir da análise da temática existencial e das variações do ponto de vista do sujeito-narrador e do próprio discurso literário, uma leitura global da obra da escritora ${ }^{1}$. Como hipótese de trabalho, propõe que os escritos de Clarice Lispector, "com a unidade múltipla que os distinguem, constituem as partes dispersas de um conjunto narrativo único". Observa que os contos da autora "seguem o mesmo eixo mimético dos romances, assente na consciência individual como limiar originário do relacionamento entre o sujeito narrador e a realidade", e ressalta que “certas diferenciações específicas quanto à história propriamente dita e ao esquema do discurso narrativo, resultam, como no romance, do ponto de vista assumido pelo sujeito narrador em relação ao personagem" (p.83-4). Na análise da variação do ponto de vista do sujeito-narrador, dois conceitos estudados por Nunes se destacam: o de monocentrismo da forma, que em relação aos romances Perto do coração selvagem e $O$ lustre diz respeito à observação de que o "eu narrador subsidia a reflexão das personagens, mas delas se retrai a todo custo, evitando assumir a identificação latente ao aparato monologal da narrativa"; e o de drama da linguagem, que em relação ao romance $A$ maçã no escuro diz respeito à observação de que "o eu narrador vem colar-se ao lado da personagem, apresentando-se no cenário comum que ambos ocupam: a representação épica das ações pouco ou quase nada se distingue da reflexão dominante, que narra meditando e especulando". Os dois conceitos são retomados no capítulo "O movimento da escritura", que data de 1972, e permitem ao crítico sintetizar análises anteriores, observando que no romance $A$ paixão segundo G.H., o primeiro da autora com ponto de vista na primeira pessoa, "o monologismo da forma reaparece, dessa vez porém identificando, sem disfarce possível, o sujeito que se faz personagem, e que manifesta, cruamente, a sua persona, a sua máscara de escritor" (p.151). Nesse sentido, Nunes considerou que em $A$ paixão segundo G.H. a autora expunha a ficcionista problematizando a forma narrativa e, com isso, revelava-se,

afinal, o personagem único que as diferentes personagens de Clarice Lispector configuram. Sabemos agora que todos exerciam uma função provisória de

\footnotetext{
${ }^{1}$ São estudadas por Nunes as obras Perto do coração selvagem, O lustre, A cidade sitiada, A maçã no escuro, A paixão segundo GH, Uma aprendizagem ou o livro dos prazeres, Água viva, A hora da estrela, Um sopro de vida, Laços de família, A legião estrangeira e Felicidade clandestina.
} 
suplência. A verdade de Joana, de Virgínia, de Lucrécia Neves, de Martim e de G.H. é a verdade do escritor, a quem pertence a paixão da existência e da linguagem que lhes tinha sido delegada (NUNES, 1969, p.151).

No presente trabalho, recuperaremos aspectos das leituras de Nunes sobre os narradores claricianos, observando que, por se colocarem próximos à consciência das personagens e refletirem também sobre a matéria narrada, seus narradores podem ser vistos como personagens escritores. $\mathrm{Na}$ medida em que pensam como artistas, semelhantemente a Benedito Nunes, entendemos que seus narradores são um só. Ao realizar a leitura do corpus, tivemos como objetivo investigar a consciência reflexiva dos narradores claricianos que aludem ao modo como eles e as personagens vêem, pensam, imaginam, escutam o mundo, permitindo-nos discutir relações entre a narrativa da escritora e outras artes.

Atendendo à sugestão de Carlos Mendes de Sousa (2000, p.45), em Clarice Lispector: figuras da escrita, de que "qualquer leitura que pretenda delinear uma trajetória na obra de Clarice Lispector e nela encontrar linhas de coerência deve justamente começar por se deter no primeiro livro", posto que "embrionariamente aí se encontrava tudo o que de marcante viria a singularizar a obra da escritora", nosso corpus é constituído pelo romance Perto do coração selvagem (1943); contos de Laços de família (1960) - "O jantar" e "Devaneio e embriaguez duma rapariga"; e textos e contos de A legião estrangeira (1964) - "Gastão Manoel Henrique", "Paul Klee", "Abstrato e figurativo", "Irmãos", "Uma porta abstrata", "Os desastres de Sofia" e "O ovo e a galinha".

A presença da expressão "objetos gritantes" em nosso título revela que fomos seduzidos pelo título inicial que recebeu a obra de Clarice Lispector posteriormente intitulada Água viva $(1973)^{2}$. Porém, é preciso esclarecer que nossa procura por “objetos gritantes" pretende realizar um estudo que leve em consideração as tensões entre formalização e representação presentes na narrativa clariciana - e não significar que a narrativa reproduz por meio da linguagem uma realidade facilmente reconhecível.

Propomos que as discussões críticas sobre as fontes da arte moderna e sobre a arte moderna no Brasil têm muito a contribuir para as leituras da obra clariciana.

\footnotetext{
${ }^{2}$ A obra Água viva (1973), antes de ser publicada, como informa Nádia Gotlib (1995), recebeu o título Atrás do pensamento: monólogo com a vida e, posteriormente, Objeto gritante.
} 
Alberto Tassinari (2001, p.17), autor de $O$ espaço moderno, que será discutido mais detalhadamente no segundo capítulo do presente trabalho, considera que há dois momentos na arte moderna: a fase de formação e a fase de desdobramento. Na fase de formação, a arte moderna ainda não pode ser pensada como formadora de uma espacialidade nova, pois seu espaço é naturalista e antinaturalista no sentido de que "a arte moderna formou-se tanto a partir quanto contra o naturalismo de matriz renascentista que a precedeu". Contribui para entendermos este aspecto a observação do crítico de que uma compreensão por negação do espaço da arte moderna sempre foi possível como sendo não perspectivo. $\mathrm{Na}$ fase de desdobramento, a arte moderna, chamada contemporânea, revolucionou o naturalismo, eliminando o que havia de prémoderno na arte moderna. Deu-se a depuração dos elementos espaciais não modernos que persistiam na fase de formação. Nesta segunda fase, a superfície da pintura assume a inteireza de um anteparo, ocorre a junção entre a obra e o espaço do mundo em comum, mas isso não significa que a obra contemporânea transforma o mundo em arte, pois, como observou Tassinari, ao contrário, ela solicita o espaço do mundo em comum para nele se instaurar como arte.

Concordando com os dois momentos da arte moderna estudados por Tassinari, leremos textos de Clarice Lispector produzidos nos anos 1940, 1950 e 1960 preocupados em perceber como sua escritura se relaciona com as fontes e tradições da arte moderna da fase de formação. Consideramos que desde seu primeiro romance, sua narrativa, como a de outros escritores modernos, é o equivalente literário daquilo que os artistas plásticos realizam com seus próprios meios e técnicas artísticas. Explicitamente, porém, é sobretudo na segunda parte de A legião estrangeira (1964), o "Fundo de gaveta", que questões importantes sobre arte moderna comparecem em textos que dialogam com trabalhos de artistas modernos, como "Gastão Manoel Henrique" e "Paul Klee", e textos que apresentam reflexões sobre o figurativo, o abstrato e a arte concreta, como "Abstrato e Figurativo", "Irmãos" e "Uma porta abstrata". Ao lermos estes textos, pretendemos investigar como as reflexões de Clarice Lispector sobre a arte moderna se relacionam com suas narrativas, com as fontes da arte moderna e com o que foi discutido sobre a arte moderna no Brasil dos anos 1950 e 1960. Justificam a escolha desse período os seguintes fatos: em 1951, ocorreu a I Bienal de São Paulo, evento de cuja importância para a arte moderna brasileira os críticos são unânimes em apontar; a escritora Clarice Lispector voltou a residir definitivamente no Brasil em 1959 e visitou o país em 1951 e em 1954; o período compreendido entre as duas décadas é de intensa pesquisa nas artes 
visuais brasileiras e coincide com o período de elaboração dos textos que compõem as obras Laços de família e A legião estrangeira, com exceção do conto "O jantar", de Laços de família, que foi escrito em 1943 e publicado pela primeira vez em 1946.

Sobre a arte brasileira no contexto dos anos 1950, no Catálogo da Exposição de Artistas Brasileiros do Museu de Arte Moderna do Rio de Janeiro, ocorrida em 1952, Mário Pedrosa (2004, p.243), ao observar a influência deixada nos jovens artistas brasileiros pela I Bienal de São Paulo, escreveu que aqui, como em toda parte, o movimento artístico estava vivendo de uma primeira polêmica entre figurativistas e abstracionistas e de uma segunda divisão, que se adicionava à outra como uma segunda hipoteca: "a separação dos realistas e super-realistas, dos que se agarram à realidade e os que a transpõem poeticamente". Os isolados se achavam entre os últimos, "os transfiguradores da realidade". Destacando que, para os realistas, a arte "é um nobre instrumento de educação", e "para os outros, no entanto, a realidade é sobretudo de ordem interior, e a arte serve para liberar o homem, erguê-lo acima do cotidiano", Pedrosa observava que, no Brasil, o choque se complicava com um novo elemento introduzido na querela entre abstracionistas, figurativistas realistas e figurativistas superrealistas: o nacionalismo artístico. Porém, acrescentando que mais fecundo do que discutir o assunto abstratamente era realizá-lo artisticamente, apontava que os artistas brasileiros mais atuais se arregimentavam

sob os mais diversos ramos do abstracionismo; de um lado a grande filiação dos que provém de Klee, o grande artista que conciliou a poesia e a abstração, o lirismo e a forma, o super-realismo com a transcendência plástica. De outro, os construtores, que se originam do ritmo plástico severo de Mondrian e tentam, na esteira de Max Bill e outros, dar ao mundo moderno o seu estilo definitivo e universal (PEDROSA, 2004, p. 243)

Além desses dois grupos, importa observar que o autor identificava como "também atuais, mas de um ponto de vista menos puramente plástico, os que introduziram nesse campo os conflitos sociais predominantes na nossa época" (p.243).

No catálogo da I Bienal de São Paulo, Heins Keller (1951), autor da apresentação dos artistas suíço, reclamou a ausência de Klee nesta Bienal ao observar que, da maneira pela qual estava organizada, a seção suíça dava um apanhado da contribuição da Suíça 
ao desenvolvimento da arte moderna, mas não um quadro da criação artística moderna no país, pois faltava, por exemplo, Paul Klee, Le Corbusier e Alberto Giacometti.

As obras de Klee, no entanto, não tardaram a visitar o país. Em janeiro de 1953, Mário Pedrosa publicou na Tribuna da Imprensa o artigo "Klee, o ponto de partida", informando que entre os nomes de maior significação do salão do Museu de Arte Moderna estava o de Paul Klee, com dois desenhos-aquarelas. Em dezembro do mesmo ano, a II Bienal de São Paulo, com 40 países representados e 16 salas retrospectivas, mostrava ao público 65 obras de Klee.

O texto "Paul Klee", de Clarice Lispector, faz menção ao quadro Paysage aux oiseaux jaunes (1923) deste pintor. Observa-se que além do destaque dado ao pintor nesses anos 1950 no Brasil, a escritora Clarice Lispector residiu de 1946 a 1949 em Berna, cidade onde Klee nasceu e viveu os últimos anos de sua vida.

Na passagem dos anos 1950 aos anos 1960, no Brasil, um exemplo de como a arte moderna era apresentada a um público mais amplo encontra-se nos artigos publicados no Suplemento Dominical do Jornal do Brasil, entre março de 1959 e outubro de 1960, por Ferreira Gullar (1999, p.10), compondo uma série de textos sobre "Cubismo", "Futurismo", "Movimentos russos", "Neoplasticismo", "Bauhaus", "Arte concreta" e “Arte neoconcreta". Este suplemento, de acordo com Roberto Pontual (1973, p.39), atuou "como porta-voz e difusor, entre 1957 e 1961, das pesquisas mais novas no campo das artes em geral, no Brasil e no estrangeiro". No prefácio da obra Etapas da arte contemporânea: do cubismo à arte neoconcreta, que reuniu posteriormente os artigos, Ferreira Gullar informou que pretendeu, "de um lado, imprimir um cunho didático à página de artes plásticas que mantinha naquele suplemento e, de outro, realizar uma espécie de nova leitura dos movimentos artísticos de caráter construtivo a partir da visão neoconcreta".

Como outros críticos, Ferreira Gullar (1999, p.232), no artigo "Arte concreta no Brasil”, publicado no referido suplemento, enfatizou a importância da I Bienal de São Paulo para a arte moderna brasileira ao ressaltar que, por volta de 1951, surgiram as primeiras manifestações de arte concreta no país, não como resultado natural da evolução da moderna pintura brasileira e sim como reação que se justificava pela permanência e valorização de uma arte conservadora entre nós. $\mathrm{O}$ impulso para os novos foi dado pela I Bienal do Museu de Arte Moderna de São Paulo, inaugurada em outubro de 1951, "proporcionando aos artistas e críticos brasileiros o conhecimento das 
obras abstratas ou concretas de Sofia Taeuber-Arp, Max Bill, Richard P. Lohse, Walter Bodmer, Oskar Dalvit, Leo Leuppi e outros, que integravam a representação suíça".

O segundo objetivo pretendido por Ferreira Gullar com a publicação dos artigos no Suplemento Dominical - realizar uma nova leitura dos movimentos artísticos de caráter construtivo a partir da visão neoconcreta - diz respeito à sua compreensão da arte moderna mais atual, exemplificada primeiramente no artigo "Lygia Clark - uma experiência radical", publicado no Jornal do Brasil, em 1958. Neste artigo, Ferreira Gullar, atento à eliminação da moldura e à relação da pintura com o espaço real nas obras de Lygia Clark, já ressaltava importantes observações que se relacionam com sua visão neoconcreta. Por exemplo, considerando que pintar, para Lygia Clark, não é mais trabalhar a partir de um espaço preexistente, tratou seus quadros como "objetos vivos, ambíguos":

Não existe mais para esta artista qualquer separação entre espaço e obra, entre espaço material - a tela - e o espaço virtual futuro - a obra. Porque o 'quadro' (a tela) não preexiste ao ato de pintar, porque Lygia Clark constrói simultaneamente o quadro como objeto e como expressão, ela trabalha diretamente sobre o espaço real e o transforma sur le champ. Daí porque seus quadros são esses objetos vivos, ambíguos, acionados pelo movimento constante de uma metamorfose espacial que, nem bem se faz, já se refaz: absorve, transforma e devolve o espaço, incessantemente (GULLAR, 1999, p.270).

Mas, a visão neoconcreta de Ferreira Gullar e dos artistas do grupo ficou esclarecida no "Manifesto neoconcreto", lançado durante a I Exposição Neoconcreta", de março de 1959:

Não concebemos a obra de arte como 'máquina' nem como ‘objeto', mas como um quase-corpus, isto é, um ser cuja realidade não se esgota nas relações exteriores de seus elementos; um ser que, decomponível em partes pela análise, só se dá plenamente à abordagem direta, fenomenológica. Acreditamos que a obra de arte

\footnotetext{
${ }^{3}$ De acordo com Gullar (1999, p.244), "sete artistas participaram da I Exposição Neoconcreta, que reuniu trabalhos de pintura, escultura, gravura, poesia e prosa. Estes artistas são: Almicar de Castro (escultor), Ferreira Gullar (poeta), Franz Weissmann (escultor), Lygia Clark (pintora), Lygia Pape (gravadora), Reynaldo Jardim (poeta) e Theon Spanúdis (poeta). Mais tarde, integraram-se ao movimento Willys de Castro, Hércules Barsotti, Décio Vieira, Hélio Oiticica, Osmar Dilon, Roberto Pontual, Carlos Fernando Fortes de Almeida e Cláudio Melo e Souza".
} 
supera o mecanismo sobre o qual repousa, não por alguma virtude extraterrena: supera-o por transcender essas relações mecânicas (que a Gestalt objetiva) e por criar para si uma significação tácita (M. Ponty) que emerge pela primeira vez. Se estivéssemos que buscar uma símile para a obra de arte, não o poderíamos encontrar, portanto, nem na máquina nem no objeto tomados objetivamente, mas, com S. Langer e W. Wleidlé, nos organismos vivos. Essa comparação, entretanto, ainda não bastaria para expressar a realidade específica do organismo estético (GULLAR, 1999, p.285-6).

Observa-se no texto acima a recusa da concepção de "objeto" para se referir à arte atual, no entanto, foi no texto "Teoria do não-objeto", também publicado no suplemento do Jornal do Brasil em 1959, que Ferreira Gullar (1999, p.289-90) explicou o sentido do nome não-objeto em arte: o não-objeto não é um antiobjeto, mas um “objeto especial em que se pretende realizada a síntese das experiências sensoriais e mentais: um corpo transparente ao conhecimento fenomenológico, integralmente perceptível, que se dá à percepção sem deixar resto. Uma pura aparência". Traçando rapidamente o percurso que a pintura moderna realizou até chegar ao não-objeto, explicou também por que, na visão neoconcreta, a pintura não-figurativa de Mondrian e Malevitch ainda não é um nãoobjeto: "nos quadros de Mondrian e Malevitch permanece a oposição da figura geométrica sobre um fundo metafórico, de representação" (p. 297). Para Gullar, a arte contemporânea só em alguns casos ultrapassou o problema da representação: os contrarelevos de Tatlin, as arquiteturas suprematistas de Malevitch, que "estão fora das definições do que seja pintura, escultura, arquitetura", e os trabalhos do grupo neoconcreto. O nome não-objeto resulta da seguinte compreensão: "uma arte realmente não-representativa repele as noções acadêmicas de gênero artístico. $\mathrm{O}$ próprio conceito de arte vacila, se não o tomamos na acepção fundamental de experiência primeira" (p. 298-9).

Para os neoconcretos, a discussão do não-objeto em arte envolvia mais do que a eliminação da representação de objetos reconhecíveis, ou a abstração geométrica, pois consideraram imprescindível o abandono do suporte tradicional da pintura - a superfície plana da tela. Uma síntese de suas idéias encontra-se na passagem abaixo, extraída do artigo "Poéticas políticas: as artes plásticas entre o golpe de 64 e o AI-5", de Artur Freitas: 
O neoconcretismo, dissidência carioca do movimento concreto desde 1959, aglutina à sua volta as principais produções e discussões do período. $\mathrm{O}$ espaço da pintura parece tender a derramar-se pelo espaço do mundo real. A relação figurafundo, o uso da moldura na pintura e inclusive a própria separação tradicional entre pintura e escultura, tudo é revisto e parece perder o sentido. Ao rigor gestaltista e semiótico do concretismo - sobretudo o paulista defendido pelos irmãos Campos e Décio Pignatari - os neoconcretos respondem com a consideração simbólica do corpo, com a subjetividade fenomenológica de Merleau-Ponty e com o último projeto de reintegração da arte à vida. Os últimos resquícios da espacialidade profunda e metafórica pretendem-se eliminados. A arte parece pronta a participar do cotidiano que the rodeia. A representação, enquanto arranjos de elementos sobre um fundo simbólico, é substituída pela simples presença corpórea da obra, o que não é pouco à compreensão da arte no Brasil ou em qualquer lugar. Surgem os Relevos espaciais, de Hélio Oiticica, o Livro da criação, de Lygia Pape, e os Casulos e os Bichos de Lygia Clark, objetos simplesmente apresentados à experiência e independentes da tradicional tarefa de mediação simbólica; ou ainda, nas palavras de Ferreira Gullar, autênticos não-objetos oferecidos à percepção (FREITAS, 2004, p.66-7).

Adotando as duas fases da arte moderna estudadas por Alberto Tassinari e observando que a visão neoconcreta sobre o não-objeto em arte se aplica à arte moderna da fase de desdobramento, à arte contemporânea brasileira, pensamos que há na poética de Clarice Lispector uma passagem do moderno ao contemporâneo em correspondência com as artes plásticas. Na fase moderna, foco do presente trabalho, situamos as obras anteriores a Água viva, propondo que suas narrativas sejam pensadas como obras em que se pode observar a representação do acontecimento, porém, mais do narrá-lo, o narrador clariciano alude à sensação que o envolveu. Chamamos de "objetos gritantes" aos figurativos sutis e nuançados de sua escritura, pois transcendem a mera aparência exterior da realidade e confundem-se com o que se chama muitas vezes de abstrato. Uma compreensão deste figurativo pode ser verificada no pequeno texto "Abstrato e figurativo", no qual Clarice Lispector define o abstrato como "o figurativo de uma realidade mais delicada e mais difícil, menos visível a olho nu”. Aspecto semelhante sobre o figurativo menos visível a olho nú pode ser observado nos Diários de Paul Klee (1990, p.415) quando lemos o pintor escrever que, após desbravar seu caminho pelo 
mundo da forma, sentia-se capaz de voltar a ser ilustrador de idéias: "Então, passei a não ver mais a arte como abstrata. Restou apenas a abstração da transitoriedade. $O$ objeto continuava sendo o mundo, ainda que não este mundo visível".

Um paralelo desse figurativo na pintura brasileira do período pode ser buscado na obra de Alfredo Volpi, pintor de quem Roberto Pontual (1973, p.42) escreveu que "sobretudo nas décadas de 1950 e 1960, constitui caso especial de diálogo entre o figurativo e o abstrato". Pontual considera que o que melhor parece caracterizar o pintor "é seu propósito de reconstruir a realidade exterior, fundindo a fonte popular de base com processos não-intelectualizados de refinamento formal, de modo a reencontrar a autonomia do olhar que, ao ver o mundo, logo o refaz" (p.61). O pintor Alfredo Volpi foi, inclusive, comparado a Paul Klee, por exemplo, por Rodrigo Naves (1996, p.180), ao escrever que, "sem falar das evidentes afinidades poéticas, vemos em ambos a vontade de deixar à mostra a gênese dos trabalhos, e a resistência a uma definição formal que vede a perspectiva de novos arranjos combinatórios".

Clarice Lispector voltou a residir no Brasil em 1959, nesse período, os contos de Laços de família já tinham sido escritos e alguns contos e textos de A legião estrangeira vieram a público pela primeira vez na revista Senhor entre 1960 e 1961. A obra Água viva, por sua vez, foi publicada em 1973 e, como informou Nádia Gotlib (1995), trabalhada pela autora nos três anos anteriores. De acordo com a biógrafa Teresa Cristina Montero Ferreira (1999, p.255), autora de Eu sou uma pergunta: uma biografia de Clarice Lispector (1999), a idéia para a publicação desta obra surgiu após o jornalista e poeta Álvaro Pacheco, fundador da editora Artenova, sugerir a Clarice Lispector "escrever um livro 'abstrato":

Foi então que ela começou a juntar anotações feitas há muitos anos, alguns trechos inclusive publicados em sua coluna no JB [Jornal do Brasil], para compor um livro. Em julho de 1971, concluiu Atrás do pensamento: monólogo com a vida. Um livro completamente diferente do que havia escrito até então. Nesse mesmo mês recebeu a visita do professor Alexandrino Severino, a quem confiou os originais do novo livro para que fosse traduzido para o inglês (FERREIRA, 1999, p.255).

Alguns textos de Clarice Lispector publicados no Jornal do Brasil de agosto de 1967 a dezembro de 1973 reaparecem em Água viva. Perguntada sobre este aspecto durante seu depoimento ao Museu da Imagem e do Som, do Rio de Janeiro, a escritora 
respondeu: "eu estava escrevendo o livro e detestava fazer crônicas, então, eu aproveitava e publicava. E não eram crônicas, eram textos que eu publicava" (OE, p. 148). Em Água viva reaparecem textos do "Fundo de gaveta" modificados, a exemplo do texto "Gastão Manoel Henrique", também publicado no catálogo de uma exposição do pintor homônimo do título. A obra não foi traduzida por Alexandrino Severino. De acordo com Gotlib, em entrevista, Clarice Lispector declarou:

Esse livrinho tinha 280 páginas; eu fui cortando - cortando e torturando - durante três anos. Eu não sabia o que fazer mais. Eu estava desesperada. Tinha outro nome. Era tudo diferente... [...] Era Objeto gritante, mas não tem função mais. Eu prefiro Água viva, coisa que borbulha. Na fonte. [...] O Álvaro interrompeu a impressão de vários livros para pegar Água viva, e nos fins de agosto a obra já estava nas livrarias (LISPECTOR, Apud GOTLIB, 1995, p.410).

Importa percebermos neste depoimento da escritora sua consciência de que, com as alterações realizadas, o título Objeto gritante passou a não ter mais função. Como epígrafe, Água viva apresenta as seguintes palavras de Michel Seuphor:

Tinha que existir uma pintura totalmente livre da dependência da figura - o objeto - que, como a música, não ilustra coisa alguma, não conta uma história e não lança um mito. Tal pintura contenta-se com evocar os reinos incomunicáveis do espírito, onde o sonho se torna pensamento, onde o traço se torna existência.

Ferreira Gullar (1999, 150), no primeiro artigo dedicado ao estudo do Neoplasticismo, informou que Michel Seuphor foi o principal historiador deste movimento tido como "primeira tentativa de encontrar a síntese da nova linguagem plástica não-figurativa”, proposta, pioneiramente, direta ou indiretamente pelo cubismo e pelo futurismo.

Entendemos que Água viva (1973) inaugura uma segunda fase na obra da escritora, mais condizente com a arte moderna da fase de desdobramento, ou arte contemporânea, conforme conceituação de Alberto Tassinari. Sinalizamos que as leituras desta obra têm muito a ganhar com as discussões em torno da arte contemporânea, especialmente no que diz respeito às discussões empreendidas pelos artistas e críticos brasileiros a respeito das experiências concretas e neoconcretas. 
A permanência da expressão "objetos gritantes" em nosso título se justifica também pela observação de que nosso primeiro contato com as narrativas de Clarice Lispector deixou em nós a impressão de uma escritura que, antes de dizer algo que pudéssemos compreender, atraia-nos simplesmente por nos remeter a seus aspectos visuais e auditivos. A expressão "objetos gritantes" aponta para nossa disposição, desde essas primeiras leituras, para ver, ouvir, sentir - imagens, sons e silêncios em seus textos. Nesse sentido, Jean-François Lyotard (1979), em Discours, figure, obra de 1971, observou que o símbolo verdadeiro dá o que pensar, porém, antes, se dá a ver, e considerou que o surpreendente não é que dê o que pensar, afinal, uma vez que existe a linguagem, todo objeto depende de um significar. O enigma é que esteja por 'ver', que se mantenha incessantemente sensível, que haja uma reserva de 'vistas', ou um intramundo que seja uma reserva de 'visões', e qualquer discurso se esgote antes de seu fim. Algo próximo desta passagem de Lyotard pode ser observado no texto "Literatura de vanguarda no Brasil", de Clarice Lispector, proferido como palestra pela primeira vez no Texas, em 1963, e depois em diversos lugares do nosso país. Como Lyotard, as palavras da escritora nos fazem pensar na arte como um por "ver", "ouvir", "sentir", “experimentar" que subsiste ao tema:

Um 'tema', sim, pode preexistir, e dele se pode falar antes, durante e depois da coisa propriamente dita; mas o fundo-forma é a coisa propriamente dita, e do fundo-forma só se sabe do ler, ver, ouvir, experimentar. Eu me propus: tema, e a coisa escrita; tema, e a coisa pintada; tema, e a música; tema, e viver (OE, p.98).

Nossa procura por objetos gritantes, na medida do possível, é uma tentativa de ver, ouvir, sentir, experimentar a narrativa clariciana.

Observando também a sugestão de Michel Butor (1974, p.232) quanto à necessidade de, na modernidade, colocarmos "em novos termos o problema da relação da literatura com as outras artes concernentes ao ouvido ou ao olho, à música e à pintura", faz parte dos nossos objetivos ler o romance Perto do coração selvagem procurando perceber como a presença auditiva, a existência das personagens e a estrutura da narrativa se relacionam entre si.

Michel Butor (1969, p.15), em um pequeno ensaio sobre o romance moderno de James Joyce, escreveu que o autor de Finnegans Wake, ficando cada vez mais cego à medida que elaborava a obra, "se tornou cada vez mais sensível à natureza sonora do 
material que empregava e ao íntimo parentesco que liga o romance não apenas à poesia como também à música". Excetuando a deficiência visual que afetou James Joyce, consideramos que as palavras de Butor sobre a sensibilidade do escritor em relação à natureza auditiva da linguagem e ao parentesco entre romance, poesia e música se aplicam também à autora de Perto do coração selvagem.

Sobre a relação da literatura com a pintura propomos investigar homologias formais e estruturais entre os procedimentos da escritora e o de certos pintores modernos.

Pensando o romance $A$ maçã no escuro, de Clarice Lispector, terminado em 1954 e publicado em 1961, Gilda de Melo e Souza (1989, p.81) escreveu palavras válidas também para as narrativas que estudaremos neste trabalho, ao ressaltar que o desejo da autora "é transmitir ao leitor a sensação de estar presente no momento em que acontece o que acontece", podendo ser chamada de "romancista do instante".

A ênfase na sensação e no instante pode ser observada também na pintura moderna. Em 1952, o pintor Francis Bacon observou que "um quadro deve ser a recriação de um acontecimento, e não a ilustração de um objeto: mas não há tensão no quadro a menos que se lute com o objeto". A imaginação real, para este pintor, "é a busca da técnica para capturar o objeto num dado momento", mas ressalta: "a técnica e o objeto tornam-se então inseparáveis. O objeto é a técnica e a técnica é o objeto. A arte reside na luta contínua para nos aproximarmos do lado sensorial dos objetos" ${ }^{\text {.4 }}$

Estudando a pintura de Francis Bacon, Gilles Deleuze (2005, p.42) considerou que o fio que liga Bacon a Cézanne é "pintar la sensación, o, como dice Bacon com palabras muy próximas a las de Cézanne, registrar el hecho". Ao perceber que Bacon elimina o sensacional na Figura, Deleuze entendeu o sentido da seguinte fórmula do pintor: "he querido pintar el grito antes que el horror" (p.45).

A luta do artista assim percebida por Bacon e discutida por Deleuze é semelhante à luta pela expressão observada na narrativa de Clarice Lispector. Em algumas passagens de nosso trabalho, voltaremos a esta aproximação, mas esclarecemos que em nossa discussão das homologias estruturais entre narrativa e pintura, optamos pelo estudo do espaço moderno, trabalhando com duas concepções de espaço na narrativa clariciana: o espaço como ambiência onde se localizam os personagens; e o espaço da escritura como um espaço plástico que se assemelha à extensão da superfície de uma

\footnotetext{
${ }^{4}$ De acordo com Chipp (1988, p.633), “declaração de 1952, extraída de uma entrevista publicada em Time (Nova York), 1952 ".
} 
tela, neste caso, a folha na qual o texto é exposto. As duas concepções de espaço relacionam-se com duas funções complementares que pensamos existir nas narrativas claricianas aqui estudadas: a figuração e a exposição. Pela primeira, a narrativa deixa ver personagens, ações, acontecimentos, espaços, eventos etc; e, pela segunda, expõe sinais do fazer 5 .

Sobre o espaço como ambiência, Benedito Nunes (1969, p.114) considerou que, no universo da romancista Clarice Lispector, "o ambiente é Espaço, e o Espaço meio de inserção da existência”. As paisagens naturais e urbanas não têm importância em si mesmas, apenas "exteriorizam, integralmente, em cada caso, o ser-no-mundo da existência humana", daí, como ressalta, "a inevitável abstração de particularidades locais, de dados sociais, e, por fim, dos elementos objetivos da realidade". Esta concepção de espaço nos permite encontrar analogias com o espaço polissensorial da pintura moderna estudado por Pierre Francastel em Pintura e sociedade.

Carlos Mendes de Sousa (2000, p.347), como ele mesmo escreveu, "procurando delimitar uma designação operatória para indicar o texto que deixa aparecer as fissuras, as costuras, os próprios restos incorporados, designação que reenviará também para o domínio da metadiscursividade e para o âmbito da enunciação que reflete o próprio fazer", utilizou a expressão "texto exposto" para a narrativa de Clarice Lispector. Ao estudarmos o espaço da escritura como um espaço plástico, recorreremos ao conceito de "espaço em obra" estudado por Alberto Tassinari (2001), pois, como foi dito por este autor a respeito da pintura moderna, a narrativa clariciana também nos dá algo pronto que pode ser visto como ainda se fazendo.

A obra Água viva começa justamente com o enunciador explicitando sua liberdade em face da categoria de gênero narrativo:

É com alegria tão profunda. É uma tal aleluia. Aleluia, grito eu, aleluia que se funde com o mais escuro uivo humano da dor de separação mas é grito de felicidade diabólica. Porque ninguém me prende mais. Continuo com capacidade de raciocínio - já estudei matemática que é a loucura do raciocínio - mas agora quero o plasma - quero me alimentar da placenta (AV, p.9).

$[\ldots]$

\footnotetext{
${ }^{5}$ A elaboração dessas duas funções se deve em parte à observação de João Adolfo Hansen feita no decorrer do exame de qualificação da tese, ao nos propor pensar que os textos narrativos de Clarice Lispector têm duas funções complementares, a figuração, em que aparecem coisas e estados de coisas, personagens, ações, eventos etc., e a avaliação, feita como um ponto de vista autoral evidenciado na forma dos atos de enunciação.
} 
Que mal porém tem eu me afastar da lógica? Estou lidando com a matéria-prima. Estou atrás do que fica atrás do pensamento. Inútil querer me classificar: eu simplesmente escapulo não deixando. Gênero não me pega mais" (AV, p.12-3).

César Mota Teixeira (2001), em sua dissertação de mestrado, realizou uma leitura analítico-interpretativa de Água viva e concluiu que, na obra clariciana, Água viva representa a culminância do que foi iniciado em Perto do coração selvagem. Para o crítico, a narradora-pintora da obra "se lança no registro de cada vivência no aqui-agora da enunciação", e com isso,

a moldura ficcional ou mimética do texto se vê tomada pelo 'discurso do escritor no ato mesmo de escrever' (o que vem a compensar o esvaziamento ou a rarefação épica da narrativa). Em outras palavras, AV propõe-se deliberadamente como uma obra de 'destruição ficcional' (... 'gênero não me pega mais' ...AV. p.13) na qual a mimesis de personagens ou de ações cede lugar à fala da narradora no 'momento presente' da luta pela expressão (TEIXEIRA, 2001, p.208).

Considerando que no primeiro romance da escritora, ao lado da mimesis de personagens e de ações, já se observava a "fala da narradora no momento presente da luta pela expressão", ou seja, a figuração e a exposição, propostas no presente trabalho como funções complementares na narrativa clariciana, podemos ressaltar que a culminância realizada em Água viva diz respeito à observação de que a figuração cedeu lugar à exposição do ponto de vista da narradora-artista.

A narradora-pintora de Água viva, muitas vezes, alude à pintura e à música. Este aspecto justifica a atenção que o texto tem recebido dos críticos quando se trata do tema literatura e outras artes na obra de Clarice Lispector, porém, a fortuna crítica da autora também tem estudado a relação da narrativa com as outras artes em outros textos, observando, com freqüência, os aspectos sensitivos de sua escritura.

A ênfase no olhar presente em sua narrativa já foi destacada por diferentes críticos. Amareles Guimarães Hill (1976), por exemplo, sobre Perto do coração selvagem, escreveu:

quem fala são os objetos, a luz do dia e as folhas das árvores. O mundo flui no habitual, cada objeto diz de si o que é. O quotidiano passado pelo homem ocupado 
em 'cuidar da vida' é a matéria descoberta pela romancista. Ela descama o habitual e deixa à mostra as camadas ocultas do óbvio (HILL, 1976, p.139).

O procedimento de Clarice Lispector assim descrito é comparável ao dos novos romancistas franceses em relação à fixação do ambiente, pois Leyla Perrone-Moisés (1966, p.22), estudando o novo romance francês, entre outras características, destacou a apreensão do mundo pelo sentido da visão, observando que, na fixação de ambientes, "o olhar do romancista se movimenta como uma câmera, registrando implacavelmente tudo o que cai sob seu olho, o grande, o pequeno, o significativo, o insignificante, e não como o olhar humano que seleciona e só vê realmente o que lhe interessa". Uma aproximação entre a narrativa de Clarice Lispector e a dos novos romancistas pode ser verificada no estudo de Regina Pontieri (2001, p.18) ${ }^{6}$ sobre o olhar na narrativa clariciana ao escrever que é possível estabelecer "uma aproximação entre o olhar fenomenológico de Clarice e o dos novos-romancistas franceses, cujas propostas de renovação novelesca apareciam na década seguinte à da permanência de Clarice em Berna". Sobre $A$ cidade sitiada, de Clarice Lispector, e $O$ Ciúme, de Robbe-Grillet, sem deixar de ressaltar as respectivas particularidades, considera que há semelhanças técnicas e, em ambos, o olhar que apenas "enfatiza o estar-aí das coisas” (p.19).

Olga de Sá (1979, p.328), primeira estudiosa a realizar um estudo da fortuna crítica da obra de Clarice Lispector, apontou a epifania como um procedimento básico da escritura clariciana que a desloca para o sensível. Segundo Sá, a escritura de Clarice Lispector "orienta-se para o pólo da sensibilidade e se coagula em superícones, reforçados por paronomásias, sinestesias, anagramas, aliterações”. Ao ressaltar que a metáfora, "como signo em relação a seu objeto, é considerada por Pierce um hipo-ícone ou um ícone "degenerado"”, explica: “o ícone é um signo que retrata, imita seu objeto, vale dizer que tem pelo menos um traço em comum com ele. Por exemplo: uma fotografia". E, sendo assim, concluiu: "Ora, a escritura de Clarice Lispector aspira a ser uma fotografia, uma pintura, vibração do som, que se ouve com as mãos" (p.330).

Recentemente, muitos trabalhos acadêmicos investigaram mais detidamente relações entre narrativa e outras artes na obra de Clarice Lispector ${ }^{7}$. Duas observações podem ter relação com esse fato: nas últimas obras da escritora, é freqüente a recorrência

\footnotetext{
${ }^{6}$ Trata-se da obra Clarice Lispector: uma poética do olhar. Regina Pontieri (2001, p.32-5) realiza uma leitura do romance $A$ cidade sitiada "contra o pano de fundo de outras obras" de Clarice Lispector. A parte analítica do trabalho começa com a leitura do capítulo "A tia", do romance Perto do coração selvagem e, na conclusão, o texto "O ovo e a galinha" é abordado "como fecho das reflexões sobre o tema "ver o outro" (p.32-5).
} 
explícita às outras artes; e, nos anos 1970, ela também exerceu a pintura. No que tange à segunda observação, Nádia Battella Gotlib escreveu:

Foi por volta de 1975, durante uns dois ou três meses que Clarice se dedicou à pintura, como um mero passatempo. No decorrer desse ano e do seguinte, pintou dezesseis quadros. Essa atividade mostra coerência com os fragmentos que escreve nessa época e que, depois, irão compor o universo da personagem de $U m$ sopro de vida (GOTLIB, 1995, p.477).

Ao propor um paralelo entre as duas atividades realizadas por Clarice Lispector nos anos 1970, Gotlib considerou que, na escrita, Clarice Lispector apresenta uma tendência para cada vez mais se deslocar do figurativo; e que, na pintura, detêm-se "em cores e linhas, com manchas fortes, em construção que indica inquietação e turbulência interior" (p.477).

Podemos falar em explicitação interna (por parte da personagem) e externa (por parte da escritora) do desejo de pintura. A primeira pode ser observada, por exemplo, em um texto dos anos 1950, o conto "Devaneio e embriaguez duma rapariga", no qual a "sensibilidade artística" é requerida pela protagonista dona-de-casa que se reconhece como alguém que "sempre fora pelas obras d'arte". Na explicitação externa, além de Clarice ter exercido a pintura, vale observar, junto com Lúcia Helena Vianna (1998, p. 52-3), que o interesse da escritora por outras linguagens artísticas "também se revela nas entrevistas reunidas no livro De corpo inteiro, nas quais dialoga com simplicidade com Djanira, Carlos Scliar, Bruno Giorgi, Iberê Camargo, Oscar Niemeyer”. A este livro, vem reunir-se um mais recente intitulado Entrevistas - Clarice Lispector (2007), que traz quatro seções divididas de acordo com a área de atuação dos entrevistados: "Literatura", "Música", "Artes cênicas" e "Esportes". No que tange às artes plásticas, foram acrescentadas as entrevistas feitas com Carybé, Mário Cravo, Augusto Rodrigues, Fayga Ostrower e Maria Bonomi (que Clarice Lispector conheceu quando ainda morava em Washington e de quem se tornou amiga).

\footnotetext{
${ }^{7}$ Por exemplo, as seguintes dissertações e teses defendidas na Universidade de São Paulo: Clarice Lispector: figuras da escrita, no capítulo "Do desenho, da escultura e da pintura", tese de Carlos Mendes de Sousa (2000); A poética do instante: uma leitura de Água viva, de Clarice Lispector, dissertação de César Mota Teixeira (2001); Um olhar estrangeiro sobre a obra de Clarice Lispector - leitura e recepção da autora na França e no Canadá (Quebec), no capítulo "A música e a pintura: a linguagem como prisão e outras formas de transcendências", tese de Lúcia Peixoto Cherem (2003); e Retratos em Clarice Lispector: literatura, pintura e fotografia, tese de Ricardo Iannace (2004).
} 
Uma aproximação entre os aspectos pictóricos da obra clariciana e as possíveis leituras realizadas pela escritora foi ressaltada por Carlos Mendes de Sousa (2000, p.277) ao considerar que "um vastíssimo suporte de leituras, feitas sobretudo nos anos em que Clarice esteve fora do país, sustenta uma extraordinária base de apoio ao modo como ela se encontrou nas intuições e inspirações". No capítulo dedicado ao estudo da pintura na narrativa da escritora, Sousa lembra que, em 1945, o pintor Giorgio De Chirico retratou Clarice Lispector e ressalta que as referências do âmbito pictórico são visíveis sobretudo em Água viva e Um sopro de vida, mas pode-se encontrar em alguns textos reenvios (especialmente do plano vocabular) que provêm do universo das artes plásticas, a exemplo do título "Esboço da cidade", de um dos capítulos de A cidade sitiada. Após observar que talvez seja possível inferir algo acerca da influência do pintor Giorgio De Chirico sobre Clarice Lispector, aproxima algumas descrições presentes no romance $A$ cidade sitiada de algumas pinturas De Chirico. Como ressaltou, em sua interpretação das esculturas gregas e das figuras mitológicas convocadas a partir do texto de $A$ cidade sitiada pensa "igualmente na presença dessas figuras no mundo do pintor italiano - a atualidade de um universo onde se encontra a memória do mundo clássico em forma de reconstruções cenográficas" (p.288).

Sousa considerou também que as traduções e textos da escritora que tratam de arte mostram o interesse de Clarice Lispector pelas artes plásticas, especialmente, pela pintura, e propõe que embora possa haver fundamento nas reservas a textos que acolhem o nome de Clarice Lispector como tradutora, a exemplo de Luzes acesas, de Bella Chagall, ou de O retrato de Dorian Gray, de Oscar Wilde, não se deve "deixar de refletir sobre a possível interferência (alguma contaminação?) desses textos e sobre a influência que terão exercido na feitura da obra" (p.287).

Com o presente trabalho, esperamos contribuir para a discussão sobre a narrativa da escritora Clarice Lispector e outras artes, tema que já tem espaço reservado em sua fortuna crítica. Para tanto, o trabalho está dividido em três capítulos: no primeiro, partindo de uma discussão sobre o Ut pictura poesis, focalizamos a comparação entre as artes na modernidade, valendo-nos, inclusive, de dois textos de Clarice Lispector sobre sua escritura ("Romance" e "Escrever, humildade, técnica", ambos da obra A legião estrangeira); no segundo, realizamos um estudo sobre o espaço plástico que nos auxilia na compreensão da arte moderna e na discussão das homologias estruturais entre o espaço da narrativa clariciana e o espaço da pintura moderna; no terceiro, dedicamo-nos à leitura do romance Perto do coração selvagem (1943); dos contos "O jantar" e 
"Devaneio e embriaguez duma rapariga", de Laços de família (1960); dos textos “Gastão Manoel Henrique”, "Paul Klee”, “Abstrato e figurativo”, "Irmãos”, "Uma porta abstrata", e dos contos "Os desastres de Sofia" e "O ovo e a galinha", de A legião estrangeira (1964). 


\section{A LITERATURA E OUTRAS ARTES NA MODERNIDADE}

No texto "O paralelo das artes", Jacqueline Lichtenstein (2005, p.9-10) destacou que, a partir do Renascimento, a maioria das pessoas que escreve sobre pintura se dedica à comparação entre as artes de duas maneiras: uma mais genérica, aproximando as artes conforme estas se relacionam ao sentido da visão ou ao sentido da audição, inserida "numa longa tradição que, segundo Platão, remontaria a Simônides de Ceos, e que nos foi transmitida através da formulação feita por Horácio, no século I, em sua Epístola aos Pisãos" e tomou a forma de uma comparação entre a pintura e a poesia "Ut pictura poesis", "um poema é como um quadro"; e a outra, restrita às relações entre a pintura e a escultura, diz respeito ao problema do paragone, primeiramente formulado, nos termos novos do humanismo, por Leon Battista Alberti. A autora considera que, embora diferentes em muitos pontos, as duas comparações estão relacionadas, pois "o paragone só adquire verdadeiramente sentido no interior da problemática geral do Ut pictura poesis, na medida em que a condição atribuída à pintura, em relação à poesia, determina a condição atribuída à escultura, em relação à pintura".

De acordo com a autora, com o Ut pictura poesis, Horácio "comparava a poesia à pintura, fazendo desta última o termo referencial da comparação", criando "um privilégio em favor das artes da imagem, com as quais são relacionadas as artes da linguagem". Os teóricos do Renascimento inverteram o sentido da frase para "a pintura é como a poesia, o quadro é como um poema". Longe de um simples erro de tradução, a inversão "foi um dos meios - e certamente um dos mais importantes - que iriam permitir à pintura gozar de um reconhecimento até então reservado às artes da linguagem" (p.11). O Ut pictura poesis funcionou como "a peça essencial de um imenso empreendimento de legitimação social e teórica da pintura", atividade anteriormente denunciada por Platão como prática ilusória e sofística e, na Idade Média, vinculada ao trabalho puramente manual. Desse modo, "na medida em que a linguagem goza precisamente, desde a Antigüidade, do privilégio de ser ao mesmo tempo a ordem do discurso e da razão", a ligação constitutiva entre as duas artes serviu ao propósito de estabelecer que a pintura "provém da idéia, e não da matéria; do intelecto, e não da sensibilidade; da teoria, e não da prática". A mudança, porém, alterou não apenas o estatuto da pintura, mas também impôs a esta "as categorias da poética e da retórica, como a invenção ou a disposição, concedendo-lhe a mesma finalidade que Aristóteles 
atribuía à poesia dramática: a de contar a história” (p.12). No século XVII ainda se dirá que "o pintor deve saber "narrar com o pincel"”. Pintar, na concepção de pintura narrativa, consiste "em transpor uma seqüência narrativa, e portanto temporal, para o espaço de visibilidade que é o quadro; em descobrir os meios de representar fielmente uma história respeitando certo número de exigências próprias à composição pictórica”. Esta concepção de pintura de história, que assinalou a um só tempo o triunfo do $U t$ pictura poesis e da estética da imitação,

seria, a partir de então e durante séculos, considerada como a mais alta expressão da arte de pintar. Na realidade, contribuiria com o testemunho irrecusável da nobreza da pintura na medida em que pressupunha, tanto no pintor como no espectador, um conhecimento íntimo da literatura profana ou sagrada e da tradição interpretativa. Demonstrara que a Pintura e a Poesia são efetivamente irmãs unidas por múltiplas relações. Os pintores tomariam seus temas da literatura, transformando a narrativa em quadros, e os escritores celebrariam os pintores em seus textos revelando a significação, por vezes obscuras, dessas telas (LICHTENSTEIN, 2005, p.13).

A comparação, com freqüência, assume uma forma de controvérsia, pois envolve duas questões: a hierarquia entre as artes e a especificidade das artes. Ainda como observou Lichtenstein, dizer que a pintura é poesia muda é ocultar sua especificidade, já que a submete às artes da linguagem. Além disso, em nome da defesa da especificidade das artes, pode-se questionar a própria comparação. Em vista disso, no século XVIII, Gotthold Ephraïm Lessing (1998, p.211) recusou o paralelo entre as artes do visível e as do discurso, ressaltando, entre outras observações, que "a seqüência temporal é o âmbito do poeta, assim como o espaço é o âmbito do artista"; e, no século XIX, Charles Baudelaire, opondo-se à comparação em favor da aproximação dos sentimentos que as artes despertam no observador, considerou que

buscar a poesia na concepção de um quadro de maneira pré-concebida é o mais seguro erro de não a encontrar. Ela deve surgir sem que o artista perceba. É o resultado da própria pintura, pois ela repousa na alma do espectador e o gênio consiste em despertá-la. A pintura só é interessante pela cor e pela forma; sua 
semelhança com a poesia só se dá na medida em que esta última desperta no leitor idéias pictóricas (BAUDELAIRE, 2005, p.106-7).

A partir da metade do século XVIII discute-se bastante a questão do tema na pintura. A esse respeito, analisando as transformações do espaço plástico do Romantismo ao Impressionismo, Pierre Francastel (1990, p.114) observou que, no contexto do Romantismo, “os signos simbólicos sobre os quais se esteve de acordo durante gerações perderam sua clareza; uma nova cultura, uma nova pedagogia são elaboradas", como ressaltou, "a primeira brecha introduzida pela evolução da sociedade e da técnica surge na pintura; ela não questiona o sistema figurativo; a transformação se inicia pela crise do tema".

Em outra passagem de seu estudo, Francastel, considerando que não é demais insistir na importância da batalha do tema, localizou o começo desta batalha na metade do século XVIII e traçou um breve percurso da crise do tema. No primeiro momento, "o serviço de Monumentos do rei, já percebendo uma crise cujo fim, um século mais tarde, Paul de Saint-Victor irá apenas constatar, decide exigir dos pintores quadros representando "temas históricos"”. Para o autor, esse foi "um episódio da crise que produziu, mais ou menos nessa mesma época, La Henriade e o desmoronamento da tragédia clássica”. Certa linguagem intelectual se perdeu. O público, já ampliado, não falava mais "a língua de Ovídio e dos trágicos para transpor sem esforço seus sentimentos e seus julgamentos através dos mitos elaborados e interpretados durante séculos de pedagogia humanista". Depois, veio "a crise do Neoclassicismo", quando, mais do que nunca, o formulário erudito tornou-se "um jogo de espírito e deixou de ser efetivo". Posteriormente, foi a vez da "batalha entre os fazedores de alegorias românticas, os pintores da realidade e os que cultivam o ideal"8 (p.115).

A discussão sobre o tema, como demonstrou Francastel, prosseguiu por um longo tempo. Foi por volta de 1880 que os impressionistas, "em toda uma série de obras agradáveis, nas quais se transformaram em cronistas e ilustradores de sua época",

\footnotetext{
${ }^{8}$ Sobre "os pintores que cultivam o ideal", ler, por exemplo, a introdução do capítulo "Simbolismo e outras tendências subjetivas", de Herschel B. Chipp (1988, p.45), organizador dos documentos teóricos da arte do século XX sob o título Teorias da arte moderna, onde se lê: "Os artistas que participaram dos movimentos subjetivistas de cerca de 1885-1900 podem ser agrupados apenas porque todos rejeitaram as concepções realistas da arte que havia predominado na geração anterior; estilisticamente, variavam muito. Seguindo a liderança dos poetas avançados, afastaram-se do mundo exterior para o mundo interior dos sentimentos, em busca de seus temas".
} 
fizeram "os temas contemporâneos triunfar definitivamente, se não diante do público do momento, pelo menos diante das gerações futuras" (p.116).

Sem realizar uma análise dos detalhes do conflito que, como escreveu, "lentamente, levou os artistas de um intento de rejuvenescer a pintura modernizando os temas sem modificar, por assim dizer, a morfologia de sua arte, a uma verdadeira crise da expressão", Francastel considerou que, "o romantismo deu uma grande contribuição de imagens e idéias novas, mas evitou questionar os marcos estáveis da representação plástica do espaço"; e os realistas, "em certa medida, também acreditaram que a discussão sobre o tema dominava todas as outras", porém, os que fizeram triunfar o programa de Courbert, nas palavras do autor, "os que pareciam formar a segunda geração realista",

introduziram novidades que tornaram súbito possível uma transformação tão completa das relações entre o pintor e a natureza, entre o pintor e o espectador, e que veio sortida de uma série de invenções técnicas tão revolucionárias, que se pode afirmar ter sido virada mais uma página da história das linguagens plásticas da humanidade (Ibid, p.116-7).

Apesar do elogio acima, Francastel fez questão de esclarecer que considera os impressionistas "mais precursores do que inovadores".

Em relação à crise do tema, vale observar, ainda, que, no final do século XVIII e começo do século XIX, inicia-se, e tem sido atualizada desde então, a crise da representação, que, como bem destacou Kerstin Behnke, é "uma expressão de recente cunhagem", mas

descreve a experiência do fim do século XVIII e começo do XIX de que os sistemas de representação humana, particularmente a linguagem, considerados suficientes na época clássica, já não se mostram adequados à realidade e que, desta maneira, o termo representação perde, enquanto forma de conhecimento, sua garantia universal relativa à ordem das coisas (BEHNKE, 1994, p.7).

Observando que a validez da representação como modelo universal e invariável do conhecimento é quebrada pelo desenvolvimento da consciência histórica entre 1775 e 1825, a subjetividade nascente e a historicização do saber, Behnke ressaltou: "o vínculo 
entre linguagem e pensamento é destruído e a representação não é mais a razão oculta para a ordem das coisas" (p.13).

Simplificando, poderemos dizer que se ampliou, a partir do século XVIII, a consciência de que se pode sempre saber mais sobre tudo e, conseqüentemente, sobre nós mesmo diante dos saberes todos. Behnke, citando Foucault, continua:

A condição de 'entreligar as representações ou, entre elas, os elementos de cada uma' está agora fora da representação, em um 'espaço interno', na profundidade invisível das próprias coisas tornadas históricas e reflexivas, as quais 'se enrolam em si mesmas' e que só fragmentariamente são acessíveis à representação: 'o ser mesmo do que é representado vai agora cair fora da própria representação (Ibid, p. $13)$.

Diante desse contexto, torna-se compreensível que a crítica à pintura literária ou filosófica, à pintura de história ou de idéias, à uma pintura que continua reivindicando a doutrina do Ut pictura poesis, seja um dos temas mais insistentes do discurso da modernidade, não totalmente ultrapassado, haja vista que, como interpretou Lichtenstein, um dos mais importantes críticos de arte norte-americano do século XX, Clement Greenberg, autor do artigo intitulado "Rumo a um mais novo Laoconte", publicado em 1940, mostrasse "que a questão da especificidade das artes estava no centro das discussões relativas à abstração" (p.14-5).

Em 1948, no artigo, "A crise da pintura de cavalete", Clement Greenberg (1996, p. 165) aproximou pintura e literatura a partir da observação dos procedimentos formais realizados pelos artistas modernos. Após destacar que a superfície indiferenciada na pintura, iniciada por Manet, encontrava-se na mais recente pintura, a pintura all-over, “'descentralizada', 'polifônica' que depende de uma superfície composta de elementos idênticos ou muito semelhantes que se repetem sem uma variação marcada de uma borda a outra da pintura", em outras palavras, "um tipo de pintura que prescinde, evidentemente, de princípio, meio e fim”, Greenberg propunha que se tratava de um aspecto que parecia "corresponder a algo profundamente enraizado na sensibilidade contemporânea", e tinha seu paralelo na literatura de James Joyce e Gertrude Stein. Na conclusão do artigo, ressaltando que talvez a pintura all-over responda ao sentimento de que todas as distinções hierárquicas foram exauridas e invalidadas, "de que nenhuma área ou ordem de experiência é intrinsecamente superior, em qualquer escala de valor, a 
qualquer outra área ou ordem de experiência", anunciava que o futuro da pintura de cavalete tornou-se problemático, prevendo que "ao usar essa convenção, como o fazem - e não podem deixar de fazê-lo -, artistas como Pollock estão a caminho de destruíla" (p.167).

Como exemplo de reação contemporânea à idéia moderna de especificidade entre as artes, Lichtenstein citou o texto "Do simbolismo", de André Breton, publicado em Lê surréalisme et la peinture, em 1965. Breton (2005, p.124-5) opõe-se ao uso do termo "literário" para tratar da "pintura cuja ambição seja maior do que oferecer a imagem do mundo exterior ou, na falta disso, a exigir mais em última análise do que o prazer dos olhos", pois pergunta-se: "no sentido pejorativo da expressão, pintura literária não será exatamente aquela que restringe seu horizonte a fixar aquilo que cada um de nós pode ver todos os dias [...]?". Ele distingue uma pintura “de dissertação ociosa acerca de um mundo de ninharias" de uma pintura "que se quer recriação do mundo em função da necessidade interior do artista", ressaltando: "esta pintura está para a outra assim como a poesia, em sua acepção mais elevada, está para a prosa de 'best-seller' e para a difusão jornalística" (p.125-6). Após observar que o simbolismo poético não deixou de "aumentar seu poder de irradiação", mas a pintura simbolista foi interrompida pela pintura voltada para o espetáculo externo, concluiu que, apesar disso, "as novas energias como as do surrealismo e a da 'abstração lírica' bastariam para nos assegurar que ela nunca se perdeu nas areias" (p.129).

Uma vez que pretendemos realizar leituras de narrativas da escritora Clarice Lispector produzidas por volta de 1940, 1950 e 1960, investigando relações com outras artes, atentos às observações acima sobre a crise da representação e a crise da pintura de cavalete, torna-se importante nos determos em algumas questões críticas e teóricas sobre os estudos comparativos da narrativa com outras artes na modernidade.

O crítico e escritor Michel Butor (1974, p.232), um dos novos-romancistas franceses (romancistas que logo após a Segunda Guerra Mundial foram considerados criadores de uma "nova escola" dentro do romance francês por jornalistas e críticos), no volume de ensaios intitulado Repertório, chama-nos atenção para um aspecto que reforça a comparação entre literatura e outras artes na modernidade: o de que nos encontramos "hoje em dia diante de tais transformações dos meios de comunicação que somos obrigados a colocar em novos termos o problema da relação da literatura com as outras artes concernentes ao ouvido ou ao olho, à música e à pintura”. Como ressalta, “ouvimos muitos ruídos ao mesmo tempo, o mundo moderno é mais barulhento do que 
outrora, há mais gente falando e suas vozes são multiplicadas por inúmeros aparelhos; a questão da superposição das falas reveste-se pois de uma importância cada vez maior" (p.237). A percepção da imagem e do som foi alterada pelo cinema e pela televisão, que "transformaram a relação entre aquilo que vejo e o que ouço, atraindo nossa atenção para os aspectos visuais da dicção" (p.239).

A importância do cinema para as outras artes foi bastante enfatizada pelo autor da História social da arte e da literatura, Arnold Hauser (2003, p.970), para quem o novo conceito de tempo, "cujo elemento básico é a simultaneidade e cuja natureza consiste na espacilização do elemento temporal, em nenhum gênero se expressa de maneira tão impressionante quanto na mais jovem de todas as artes, a qual data do mesmo período que a filosofia do tempo de Bergson”. Destacando a completa concordância entre os métodos técnicos do cinema e as características do novo conceito de tempo, Hauser ressaltou que "se tem a sensação de que as categorias temporais da arte moderna, como um todo, devem ter surgido do espírito de forma cinematográfica, e fica-se propenso a considerar o próprio cinema como o gênero estilisticamente mais representativo da arte contemporânea".

No que diz respeito aos aspectos metodológicos da comparação entre as artes, os teóricos René Wellek e Austin Warren, por exemplo, propunham que a comparação da literatura com as outras artes deve priorizar a análise das relações estruturais, pois consideram que

a mais discreta forma de abordarmos a comparação das várias artes consiste, obviamente, naquela que se alicerce sobre uma análise dos próprios objectos de arte e, assim, das suas relações estruturais. Nunca teremos uma perfeita história de uma arte - para não falarmos já numa história comparativa de uma arte -, a não ser que nos concentremos na análise das próprias obras e releguemos para plano secundário os estudos sobre a psicologia do leitor e do espectador, ou do autor e do artista, bem como os estudos sobre o fundo cultural e social, por mais esclarecedores que eles possam ser dos seus específicos pontos de vista (WELLEK \& WARREN, 1955, p.163).

Mário Praz (1992, p.13), no capítulo "Ut pictura poesis", primeiro de seu livro Literatura e artes visuais, a partir da apresentação de exemplos de inter-relação entre poesia e pintura decorrentes do fato de pintores aceitarem as sugestões dos poetas 
(segundo o tema de "instruções ao pintor"), ou, o contrário, poetas buscarem inspiração no trabalho dos pintores (diante do grau de prestígio alcançado pela pintura na Renascença), ou de, no século XVIII, poetas e pintores idearem assuntos contemporâneos, ressaltou: "tal tipo de inter-relação pode ser largamente ilustrado por qualquer das literaturas do Ocidente, e embora constitua, legitimamente, um capítulo do estudo global do paralelo entre as artes, de modo algum é a sua parte mais importante". Diferentemente de René Wellek e Austin Warren (1955, p.169), que recusam a idéia de um “"espírito do tempo' determinando e infiltrando-se em toda e qualquer arte”, por entenderem as atividades culturais do ser humano tomadas como um sistema global de séries que evoluem por si próprias, cada uma com um conjunto de normas que não são necessariamente idênticas às da série vizinha, Mário Praz entende que talvez "a maneira certa de se encontrar uma base firme para os paralelos entre as diversas artes" assemelhe-se àquilo que Vladimir Propp encontrou no campo dos contos de fadas:

De igual maneira, pode-se perguntar se, sem considerar os meios em que as obras de arte são realizadas, as mesmas tendências estruturais, ou tendências similares, não estariam em ação, num determinado período, no modo por que as pessoas concebem ou vêem as coisas, ou, melhor ainda, memorizam esteticamente os fatos, e se nisto não se pode eventualmente encontrar uma base para os paralelos entre as artes. Os diferentes meios de expressão corresponderiam, então, à variedade de caracteres nos contos de fadas: a proposição de que os caracteres variam, enquanto que as funções permanecem as mesmas, encontraria sua contrapartida em outra proposição: os meios variam, a estrutura permanece a mesma (PRAZ, 1982, p.57).

Ao incluir o modo pelo qual as pessoas concebem ou vêem as coisas, ou melhor, memorizam esteticamente os fatos em um determinado período, a abordagem de Mário Praz contempla, além das relações estruturais, os contextos culturais nos quais as estruturas se inserem e, a esse respeito, vale observar algumas idéias de Claus Clüver sobre a especificidade dos estudos interartes diante dos estudos culturais. Para Clüver (1997, p.57), há dois tipos de abordagens dos estudos interartes contemporâneos, "aqueles que enfatizam os estudos de textos e de suas relações intertextuais enquanto tais e aqueles que abordam fenômenos interartes sobretudo como produtos e práticas socioculturais". Em ambos os casos, porém, como adverte, "estaremos tratando de 
questões relativas à produção e à recepção de textos, a autores e leitores, e por esta razão apenas será impossível excluir a dimensão dos contextos culturais". O risco, para o autor, está em as abordagens e interesses dos novos estudos culturais absorverem os estudos interartes, agindo como uma superdisciplina que, como informou, nos EUA e no Reino Unido, ao longo da última década, ameaça também engolfar os estudos literários e a literatura comparada. Seu texto é da década de 1990 e reflete a preocupação de alguns estudiosos da teoria da literatura diante do até então recente avanço dos estudos culturais ${ }^{9}$ nas instituições de ensino. $\mathrm{O}$ autor reconhece que os estudos interartes, determinados pelas mesmas preocupações que dominam o discurso crítico atual, devam freqüentemente coincidir com os objetivos dos estudos culturais, porém, ressalta que os vários textos que combinam ou fundem códigos semióticos diferentes requerem competência específica. Os estudos interartes, como disciplina específica, teriam como uma de suas funções a formação de leitores equipados para lidar com intertextualidade interartes.

É inegável, portanto, a necessidade do estudioso da literatura, interessado em investigar paralelos específicos com "a pintura", "o cinema", a "música" etc, complementar sua formação com estudos sobre a outra arte em foco, a fim de, lidando com os diferentes códigos semióticos, desenvolver uma metodologia de trabalho. Nesse sentido, consideramos que um excelente exemplo de aproximação entre literatura e pintura na modernidade encontra-se no artigo "A linguagem indireta e as vozes do silêncio", de Merleau-Ponty (2004, p.73), publicado originalmente em julho de 1952, na revista Les temps modernes. Ao distinguir na linguagem um uso empírico e um uso criador, o autor observa que a "palavra no sentido da linguagem empírica - isto é, a chamada oportuna de um signo preestabelecido - não o é em relação à linguagem autêntica". Nas expressões já adquiridas, "há um sentido direto, que corresponde ponto por ponto a torneios, formas, palavras instituídas. Aparentemente, não há lacuna aqui, nenhum silêncio falante". Diferentemente, o sentido das expressões que se estão realizando "é um sentido lateral ou oblíquo, que se insinua entre as palavras, é uma

\footnotetext{
${ }^{9}$ Walter Moser (1998, p.66), em artigo sobre os Estudos Literários (EL) e os Estudos Culturais (EC), propondo uma visão positiva da tensão entre ambos, esclarece: "na fase de surgimento e estabelecimento institucional dos EC, a integração pura e simples dos EL nos EC foi, de fato, sugerida muitas vezes. A formulação do título de um recente livro de Antony Easthope faz disso um programa explícito: Literary into Cultural Studies. No entanto, Easthope não é o único a propor essa relação particular, e sua formulação desse projeto está longe de ser a menos atenuada. Brantlinger segue, igualmente, a mesma linha de argumentação em apresentação dos Cultural Studies in Britain and America. Finalmente, em Eagleton, encontramos uma retórica que, tendo descoberto na teoria literária muitos defeitos e impossibilidades, acaba sugerindo a passagem dos EL aos EC.
} 
outra maneira de sacudir o aparelho da linguagem ou da narrativa para arrancar-lhe um som novo" (p.75-6). O paralelo entre literatura e pintura é proposto pelo autor a partir deste seu modo de ver a linguagem autêntica, a linguagem em sua operação de origem:

Se quisermos compreender a linguagem em sua operação de origem, teremos de fingir nunca ter falado, submetê-la a uma redução sem a qual ela nos escaparia mais uma vez, reconduzindo-nos àquilo que ela nos significa, olhá-la como os surdos olham aqueles que estão falando, comparar a arte da linguagem com as outras artes de expressão, tentar vê-la como uma dessas artes mudas. É possível que o sentido da linguagem tenha um privilégio decisivo, mas é tentando o paralelo que perceberemos aquilo que talvez o torne impossível ao final. Comecemos por compreender que há uma linguagem tácita e que a pintura fala a seu modo (MERLEAU-PONTY, 2004, p.76).

Para que este paralelo se torne mais compreensível, é preciso observar que Merleau-Ponty, partindo do fato de que os dados do sentido variam através do século, ressalta que a perspectiva clássica "é uma das maneiras inventadas pelo homem de projetar à sua frente o mundo percebido, e não o seu decalque" (p.78). Mais do que um segredo técnico para imitar uma realidade que se ofereceria igualmente a todos os homens, a perspectiva é "a invenção de um mundo dominado, possuído de parte a parte numa síntese instantânea da qual o olhar espontâneo nos dá, quando muito, o esboço ao tentar em vão manter juntas todas essas coisas que, individualmente, querem-no por inteiro". Daí, se mesmo a pintura 'objetiva' é uma criação, o autor, discordando de Malraux, considera que não "há razões para conceber a pintura moderna, por querer ser ela criação, como uma passagem para o subjetivo, uma cerimônia em glória do indivíduo" (p.80). Sua compreensão da tolerância dos pintores modernos com o inacabado relaciona-se ao modo como percebe a obra consumada: não é aquela que existe por si só como coisa, é "aquela que atinge seu espectador, convida-o a recomeçar o gesto que a criou e, pulando os intermediários, sem outro guia além do movimento da linha inventada, do traçado incorpóreo, reunir-se ao mundo silencioso do pintor, a partir daí proferido e acessível” (p.81). Na base desta compreensão está a seguinte observação: 
Já que a percepção nunca está acabada, já que as nossas perspectivas nos dão para exprimir e pensar um mundo que as engloba, as ultrapassa, e anuncia-se por signos fulgurantes como uma palavra ou arabesco, por que a expressão do mundo seria sujeita à prosa dos sentidos ou do conceito? É preciso que ela seja poesia, isto é, que desperte e reconvoque por inteiro o nosso puro poder de expressar, para além das coisas já ditas ou já vistas. A pintura moderna coloca um problema muito diferente daquele da volta ao indivíduo: o problema de saber de que modo é possível comunicar-se sem o amparo de uma Natureza preestabelecida e à qual se abriam os sentidos de todos nós, de que modo estamos entranhados no universal pelo que temos de mais pessoal (Ibid, p.82).

É, portanto, correlacionando percepção, história e expressão, como ele ressaltou, que pretende demonstrar por que é legítimo tratar a pintura como uma linguagem. Daí, ao observar que "um romance exprime tacitamente como um quadro", e que se pode "contar o tema do romance como do quadro", considera que o importante não se encontra naquilo que está dito. "O romance como relato de acontecimentos, como enunciados de idéias, teses ou conclusões, como significação manifesta ou prosaica, e o romance como operação de um estilo, significação oblíqua ou latente, encontra-se numa mera relação de homonímia" (p.111). Para Merleau-Ponty, enquanto, na pintura, o espectador não deve contar com outro guia além do movimento da linha inventada, do traçado incorpóreo a fim de "reunir-se ao mundo silencioso do pintor, a partir daí proferido e acessível", na literatura, a condição para existir a linguagem literária está em deixarmos "as palavras e todos os meios de expressão do livro se envolverem nessa auréola de significação que devem à sua disposição singular, e o escrito inteiro vire para um valor secundário onde quase assume a irradiação muda da pintura” (p.112). Em ambos os casos, Merleau-Ponty enfatiza a necessidade de percebermos a comunicação da forma.

Os textos "Romance" e "Escrever, humilde, técnica", de Clarice Lispector, publicados em A legião estrangeira, trazem reflexões sobre sua escritura e permitemnos estabelecer relações entre sua literatura e a arte moderna. No primeiro, observa-se a consciência da autora de que seu romance não se confunde com o romance "atraente", de fácil entretenimento, próximo de um tipo de pintura que Breton denominou de “dissertação ociosa acerca de um mundo de ninharias”. No segundo, a partir da reflexão 
da autora sobre sua técnica, é possível discutir relação entre seu estilo e o estilo de certos artistas plásticos modernos.

Como observou o crítico Carlos Mendes de Sousa (2000, p.294), o texto "Romance" busca "explicações às analogias de domínio pictural - a moldura e o quadro". No pequeno texto, a autora escreve sobre o romance atraente, que é diferente do seu romance, pois enuncia:

Ficaria mais atraente, se eu o tornasse mais atraente. Usando, por exemplo, algumas coisas que emolduram uma vida ou uma coisa ou romance ou um personagem. É perfeitamente lícito tornar atraente, só que há o perigo de um quadro se tornar quadro porque a moldura o fez quadro. Para ler, é claro, prefiro o atraente, me cansa menos, me arrasta mais, me delimita e me contorna. Para escrever, porém, tenho que prescindir. A experiência vale a pena, mesmo que seja apenas para quem escreveu (LE, p.139).

Um dos traços marcantes que ela destaca no romance atraente, além de aproximálo do quadro que se torna quadro apenas porque a moldura o fez quadro, é que ele “contorna quem o lê". Para discutir este aspecto, devemos observar o modo como Merleau-Ponty explicou o contorno dos objetos no texto "A dúvida de Cézanne":

O contorno dos objetos, concebido como uma linha que os delimita, não pertence ao mundo visível, mas à geometria. Se marcarmos com um traço o contorno de uma maçã, fazemos dela uma coisa, quando ele é o limite ideal em cuja direção os lados da maçã fogem em profundidade. Não marcar nenhum contorno seria retirar dos objetos sua identidade. Marcar um só seria sacrificar a profundidade, isto é, a dimensão que nos oferece a coisa, não como exposta diante de nós, mas como cheia de reservas e como uma realidade inesgotável (MERLEAU-PONTY, 2004, p.130).

$\mathrm{O}$ autor destaca o uso do contorno como procedimento que confere identidade às coisas, aprisionando-as em formas rígidas. Isso nos explica, de certo modo, a preferência pela fragmentação e pelo contorno interrompido por parte de muitos artistas modernos. 
Alberto Tassinari (2001), observando que "o contorno interrompido já se encontrava, por exemplo, na última fase de Cézanne" e que Braque e Picasso generalizaram o seu emprego durante o cubismo de 1911, analisa o contorno interrompido no quadro Telhandos em Céret (1911), de Georges Braque, e considera que

as linhas escuras de Telhados em Céret diagramam, assim, a fronteira que tanto separa um telhado do espaço exterior a ele, quanto o funde com este mesmo espaço. No limite, também os telhados acabam por se fundir uns com os outros. Daí o aspecto quase abstrato da pintura. Ou, antes, um equilíbrio entre abstração e figuração, que é correlato de um equilíbrio da fusão de coisas e espaços (TASSINARI, 2001, p.36).

Para Pierre Francastel (1990, p.170), o objetivo de Cézanne “é a descoberta dos fragmentos de natureza nos quais se exprime o interesse do pintor com relação ao mundo", e nessa nova atribuição de valores a determinados aspectos de nosso ambiente há "uma definição de novos objetos simultaneamente reais e imaginários". Desse modo, ressaltando que "a maçã será inapreensível e a montanha manejável e flexível, segundo a vontade do artista", entende que Cézanne não apenas evade-se do universo geográfico do Renascimento, mas também de

um universo mental no qual as funções recíprocas dos seres e das coisas são definidas. A arte renuncia à anedota e à história para tornar-se empirismo e panteísmo; ela escreve a história das coisas, maçãs, compoteiras, montanha; do que elas significam no tecido da vida sentimental cotidiana dos homens, para quem as possibilidades de acesso e de transformação da matéria também se modificam incessantemente (FRANCASTEL, 1990, p.170).

Neste novo universo mental, cabe observar o que escreveu o pintor Wassily Kandinsky em Do espiritual na arte (1910), concluído no ano em que pintou seu primeiro quadro abstrato, sobre os artistas buscarem na aproximação com a música os mais ricos ensinamentos: 
Para o artista criador que quer e que deve exprimir seu universo interior, a imitação, mesmo bem-sucedida, das coisas da natureza não pode ser um fim em si. E ele inveja a desenvoltura, a facilidade com que a arte mais imaterial de todas, a música, alcança esse fim. Compreende-se que ele se volte para essa arte e que se esforce, na dele, por descobrir procedimentos similares. Daí, na pintura, a atual busca do ritmo, da construção abstrata, matemática; daí também o valor que se atribui hoje à repetição dos tons coloridos, ao dinamismo da cor (KANDINSKY, 2000, p.58).

O contorno em uma obra literária pode ser observado, por exemplo, na descrição minuciosa da personagem por parte do narrador onisciente, dando ao leitor a análise de seus sentimentos e de sua aparência física, visando definir um "eu" como uma realidade esgotável. Não é isso que Clarice Lispector faz em suas narrativas. Como observou Benedito Nunes (1969, p.119), "nos romances de Clarice Lispector, o Eu, reduto da personalidade, que é a exteriorização do ser psíquico, o Eu, como base da identidade pessoal dos indivíduos, cai por terra". Constantemente desfeita e refeita, "a identidade pessoal parece mais um ideal a atingir, um produto da imaginação, uma meta a alcançar, do que um dado real".

O romance atraente, que contorna quem o lê, na descrição de Clarice Lispector, assemelha-se ao romance como mero relato de acontecimentos, ou, nas palavras de Lukács (2000, p.73), “à caricatura do romance”, descrita após destacar que apenas o romance possui uma caricatura que lhe é quase idêntica em todos os aspectos não essenciais da forma: "a leitura de entretenimento, que indica todas as características exteriores do romance, mas que em sua essência não se vincula a nada e em nada se baseia, carecendo com isso de todo o sentido".

É por oposição ao romance atraente que Clarice Lispector nos permite propor o paralelo entre seu romance e a pintura moderna que apreende da música o emprego de seus meios. Sobre sua narrativa, podemos dizer o mesmo que Clemente Greenberg observou da pintura de superfície indiferenciada: prescinde de princípio, meio e fim, e, como a pintura, parece responder ao sentimento de que as distinções hierárquicas foram exauridas e invalidadas, de que nenhuma experiência é intrinsecamente superior à outra. Daí, na obra clariciana, observarmos tantas vezes a circularidade da forma e a importância que cada passagem, cada frase, cada palavra tem igualmente na narrativa. 
No início do texto "Escrever, humildade, técnica", Clarice Lispector se refere a seu 'estilo', que, como informa, "já foi chamado de várias coisas, menos do que realmente e apenas é: uma procura humilde". O texto parece um quebra-cabeça de palavras, desarrumado e incompleto, pois começa do seguinte modo: "Essa incapacidade de atingir, de entender, é que faz com que eu, por instinto de ...de quê? Procure um modo de falar que me leve mais depressa ao entendimento". A incapacidade, longe de se reduzir a um empecilho, conduz o sujeito à procura. A autora informa que nunca teve "um só problema de expressão, meu problema é muito mais grave: é o de concepção". Sobre a palavra humildade, esclarece que a está empregando "no sentido cristão (como ideal a poder ser alcançado ou não)", "humildade que vem da plena consciência de se ser realmente incapaz", "humildade como técnica". Há uma passagem interessante que deve ser citada antes de continuarmos:

Virgem Maria, até eu mesma me assustei com minha falta de pudor; mas é que não é. Humildade como técnica é o seguinte: só se aproximando com humildade da coisa é que ela não escapa totalmente. Descobri este tipo de humildade, o que não deixa de ser uma forma engraçada de orgulho (LE, p.144. Grifo nosso).

Observando que apenas se aproximando humildemente da coisa ela não escapa totalmente, arriscamos um entendimento para a técnica da escritora: um método de escrever que integra ao momento do trabalho artístico o instante do ato perceptivo. A técnica, conjunto de conhecimentos de aplicação prática, descrita como humildade e para uso de um sujeito do fazer que se sabe "realmente incapaz", é uma técnica diferente ("é que não é"): por meio dela, a escritora põe em prática a aproximação aos poucos e obtém expressões acabadas da percepção inacabada.

Esta técnica assemelha-se à do pintor Francis Bacon, que também enfatiza a importância do instante em que o objeto é percebido, considera que a técnica e o objeto se confundem e entende que a arte reside na luta do artista para se aproximar do lado sensorial dos objetos. Igualmente, esta técnica assemelha-se ao modo como o crítico Rodrigo Naves (1996, p.183) percebe o esforço formalizador de Volpi ao considerar que o pintor "persegue uma espécie de sabedoria em ato, em que inexiste separação ou precedência entre teoria e prática, pois ambos são momentos de uma mesma atividade reflexionante, avessa ao dualismo sujeito-objeto". 
Alberto Tassinari (2004, p145), no esboço de leitura para o texto "A dúvida de Cézanne", de Merleau-Ponty, observou que na principal obra deste autor, Fenomenologia da percepção, “a percepção é compreendida como um 'acesso à verdade'. A verdade, entretanto, não nos dá nunca o acabado. Uma verdade acabada seria a paralisia do presente, a situação em que me encontro, tanto fonte de meus acertos quando de meus erros". Considerando que o inacabado da percepção permite a junção de alguns temas das duas obras de Merleau-Ponty, Tassinari observou que os dois textos, ao final, falam da liberdade. "E a liberdade, como a verdade, também nunca está pronta". Sendo assim, reflete: se é uma liberdade a busca de Cézanne, "o que há de incompletude e insatisfação nessa realização já não será só falha ou dúvida, mas também certeza de que aquilo que nos aparece ao mesmo tempo nos escapa".

O estilo moderno parece resultar desta espécie de humildade que é a um só tempo dúvida e certeza. Nesse sentido, na entrevista de Alberto Giacometti a André Parinaud, em 1962, o escultor também expõe sua luta para conseguir realizar aquilo que a todo instante lhe escapa:

Compreendi aos poucos a realidade de um certo fenômeno que chamamos escultura. Quando olho o copo, de sua cor, de sua forma, de sua luz só me chega a cada olhada uma coisa pequenina muito difícil de determinar, que pode se traduzir por um traço minúsculo, uma pequena mancha; cada vez que olho o copo ele parece se refazer, isto é, sua realidade se torna duvidosa, ou parcial... A gente o vê como se ele desaparecesse... ressurgisse... desaparecesse... ressurgisse...isto é, ele se encontra realmente sempre entre o ser e o não-ser. E é isso que se quer copiar... Todo o procedimento dos artistas modernos está nessa vontade de apreender, de possuir algo que foge constantemente. Eles querem possuir a sensação que têm da realidade, mais que a própria realidade. De toda maneira não se pode possuir tudo... O que se poderia possuir seria apenas a aparência. Da realidade só fica a aparência. Se um personagem está a dois metros de distância - ou a dez - não posso mais reconduzi-lo à verdade da realidade positiva. Se estou no terraço de um café e vejo pessoas andando na outra calçada, vejo-as minúsculas. Seu tamanho natural não existe mais! (GIACOMETTI, Apud PARINAUD, 1992, p. 75). 
Esta consciência da impossibilidade de exprimir a transitoriedade das coisas foi observada por Leyla Perrone-Moisés (1966, p.20) em relação aos "novos-romancistas" ao destacar que eles entendem o campo do romance como o campo dos possíveis, ressaltando que, "no campo da expressão, o reconhecimento das várias camadas do real e das possibilidades infinitas do tempo romanesco leva-os a uma atitude de humildade quanto à possibilidade de conhecer e de exprimir".

Erich Auerbach (2004), ao realizar o estudo da mimesis na literatura ocidental, em trabalho publicado originalmente em 1946, no capítulo dedicado à narrativa de Virginia Woolf, observou que muitas formas estilísticas (erlebte Rede, stream of consciousness ou monologue intérieur) empregadas pelos escritores para reproduzir o conteúdo da consciência das personagens foram empregadas muito antes na literatura, mas, ressaltou a diferença na intenção artística, acrescentando que, ao lado destas formas,

há outras possibilidades, sintaticamente quase inconcebíveis, de fazer com que se confunda ou até, que desapareça totalmente, a impressão de uma realidade objetiva, dominada perfeitamente pelo escritor; possibilidades que não residem no campo do formal, mas na tonalidade e no contexto do conteudístico (AUERBACH, 2004, p.482).

O exemplo dado pelo teórico é o da dúvida deixada na narrativa pelo escritor que coloca a si próprio como quem duvida, "interroga e procura, como se a verdade acerca da sua personagem não lhe fosse mais bem conhecida do que às suas próprias personagens ou ao leitor". O que está em questão é "a posição do escritor diante da realidade do mundo que representa", diferente da posição dos autores que, anteriormente, "interpretavam as ações, as situações e os caracteres das suas personagens com segurança objetiva".

Para que duvide da matéria narrada, o narrador, muitas vezes, revela-se como personagem da história e permite que a narrativa deixe de ser a história de uma personagem, de um acontecimento, etc, para ser a história da escritura, exigindo do leitor um olhar que veja além da representação. Uma narrativa dessa qualidade requererá ainda mais do leitor uma percepção da forma artística que não se confunda com a percepção da realidade vivida. Nesse sentido, Ortega y Gasset, observando que a percepção da forma artística requer acomodação diferente em nosso aparelho receptor, sobre a nova inspiração dos artistas modernos, considerou que 
aparentemente tão estravagante, volta a tocar, pelo menos num ponto, o caminho real da arte. Porque esse caminho se chama 'vontade de estilo'. Pois bem: estilizar é deformar o real, desrealizar. Estilização implica desumanização. E vice-versa, não há outra maneira de desumanizar além de estilizar. O realismo, ao contrário, convidando o artista a seguir docilmente a forma das coisas, convida-o a não ter estilo (ORTEGA y GASSET, 2005, p.47).

A concepção de desumanização na arte se torna mais clara quando Ortega explica que a propensão humana é fruto de nossa tendência natural de esquecer que há sempre uma absoluta distância entre a idéia e a coisa, confundindo a realidade com a idéia, "tomando esta de boa-fé pela própria coisa". A propensão nativa humana diz respeito ao fato de que "nosso prurido vital de realismo nos faz cair numa ingênua idealização do real" (p.64).

Um exemplo do modo como o escritor moderno entende o sentido da estilização pode ser observado nas palavras de Michel Butor (1974, p.11), ao ressaltar que "a busca de novas formas romanescas cujo poder de integração seja maior representa pois um triplo papel com relação à consciência que temos do real: de denúncia, de exploração e de adaptação". Sobre os romancistas que recusaram este trabalho, acrescenta:

não transtornando os hábitos, não exigindo de seu leitor nenhum esforço particular, não o obrigando a essa volta sobre si mesmo, a esse questionamento de posições há muito adquiridas, têm certamente um êxito mais fácil, mas torna-se cúmplice deste profundo mal-estar, desta noite em que nos debatemos. Ele torna ainda mais rígidos os reflexos da consciência, mais difícil seu despertar, contribui para a sua asfixia, tanto que, mesmo se ele tiver intenções generosas, sua obra é finalmente um veneno (BUTOR, 1974, p.12).

Mais uma vez, observamos que não é o caso da escritora Clarice Lispector, pois sua obra, como ressaltou Benedito Nunes (1989), "se reveste de uma importância exemplar - e conseqüentemente de um valor indiscutível - como paradigma do esvaziamento que se produziu na ficção contemporânea". Reportando-se ao ensaio "Posição do narrador no romance moderno", de Theodor W. Adorno, o crítico acrescentou: 
Temendo cair na 'mentira' da narração, o ficcionista dos nossos dias, que passou a desconfiar de si mesmo, e que procura opor às significações objetivas o fluxo da linguagem, também esvaziou o próprio objeto da ficção. Será impossível narrar sem questionar a forma da narrativa e o sentido mesmo da realidade. A obra de Clarice Lispector, que se desliga do mito e se volta sobre si mesma, participa desse esvaziamento do romanesco na literatura contemporânea (NUNES, 1989, p. $154)$.

Além da dúvida sobre a matéria narrada que os narradores explicitam, um outro modo de transtornar os hábitos dos leitores está em romper com a sucessão temporal. Nesse sentido, Auerbach (2004, p.497) observou que a narrativa de Virginia Woolf, ao "enfatizar o acontecimento qualquer, não aproveitá-lo a serviço de um contexto planejado da ação, mas em si mesmo", tornou "visível algo de totalmente novo e elementar: precisamente, a pletora de realidade e profundidade vital de qualquer instante ao qual nos entregamos sem preconceito".

Anatol Rosenfeld (1996, p.83), também atento ao tempo na narrativa em sua reflexão sobre o romance moderno, observou o que ocorre na estrutura da narrativa quando se leva em consideração a riqueza do instante. Partindo da observação de que o homem não vive apenas "no tempo", mas é tempo, um tempo não cronológico, pois a nossa consciência "não passa por uma sucessão de momentos neutros como o ponteiro de um relógio", e que cada instante é rico de possibilidades e expectativas, destacou que a narração torna-se "padrão plano em cujas linhas se funde, como simultaneidade, a distensão temporal". A tentativa de reproduzir este fluxo da consciência leva à radicalização do monólogo interior, pois,

o narrador, no afã de representar 'a realidade como tal' e não aquela realidade lógica e bem comportada do narrador tradicional, procura superar a perspectiva tradicional, submergindo na própria corrente psíquica da personagem ou tomando qualquer posição que lhe parece menos fictícia que as tradicionais 'ilusionistas' (ROSENFELD, 1996, p.84).

A hipótese de Rosenfeld é de que a eliminação da perspectiva linear na arte moderna é um fenômeno da pintura análogo ao fenômeno da eliminação da sucessão 
temporal ocorrido na narrativa, denominado "dissolução da cronologia", relacionado às dissoluções da motivação causal, do enredo e da personagem. Ao considerar que a perspectiva central "cria a ilusão do espaço tridimensional, projetando o mundo a partir de uma consciência individual", ressaltou que o mundo visto em relação a esta consciência é constituído a partir dela e relativizado, "mas esta relatividade reveste-se da ilusão do absoluto. Um mundo relativo é apresentado como se fosse absoluto. É uma visão antropocêntrica do mundo, referida à consciência humana que lhe impõe leis e óptica subjetiva" (p.78). A eliminação da "perspectiva ilusionista", associada à visão de mundo desenvolvida a partir do Renascimento (impossível na Idade Média, pois dependeu da reviravolta coperniciana seguida de outra anunciada pela filosofia moderna de Kant) é a expressão de um sentimento de vida ou de uma atitude espiritual que renegam ou pelo menos põe em dúvida a visão Renascentista. Na nova época, com todos os valores em transição e com uma realidade que não é mais "um mundo explicado", exigem-se adaptações estéticas capazes de encerrar esta situação na estrutura da obra. $\mathrm{Na}$ análise de Rosenfeld, essas adaptações estão relacionadas, na pintura, à eliminação da perspectiva linear e, na narrativa, às dissoluções do tempo, espaço e personagem.

No artigo "Fenomenologia do olhar", Alfredo Bosi (1988, p.80) situou o solo da nossa contemporaneidade na crise das certezas que se inicia, de certo modo, com o criticismo de Kant e marca a passagem da "Era das luzes para a era da suspeita", quando também tem lugar o pensamento de Marx, de Kierkegaard, de Nietzsche, de Freud, de Max Weber, de Heidegger, de Sartre: "um olhar que já não absolutiza o cogito, porque o situa no interior de uma existência finita e vulnerável, mas sempre inquieta, interrogante". Eis um dos mais importantes aspectos do contexto cultural da modernidade que encontra adaptações estéticas nas estruturas das obras modernas, permitindo-nos observar que, correlacionando percepção, história e expressão, é possível tratar a pintura como linguagem, como propôs Merleau-Ponty, e, conseqüentemente, comparar literatura e outras artes, sentido que, na condição de leitores, aproximamo-nos um pouco mais do fenômeno artístico. 


\section{O ESPAÇO NA ARTE MODERNA}

Pierre Francastel (1990, p.38-9), retomando aspectos do relativismo da perspectiva, discutidos anteriormente por Erwin Panofsky ${ }^{10}$, observa que "não vemos com apenas um olhar nem a natureza, nem as obras de arte", que a detalhamos, que "a unidade não está nem na tela plástica fixa nem na tela móvel do cinema, está em nosso espírito". Destacando alguns dos procedimentos usados pelo artista renascentista para representar "a profundidade, o espaço infinito do mundo tornado, enfim, uma realidade acessível e penetrável ao espírito humano", revela o engano de considerar que o Renascimento "nasceu do espetáculo da natureza fielmente (?) interpretada". Como exemplo, ressaltou: "Uccello e Piero não foram para o campo com suas caixas de tintas nas costas. Eles combinaram, em seus ateliês, métodos de conciliação da nova geometria com os procedimentos habituais da pintura para reproduzir espetáculos familiares de sua época". E, nesse sentido,

cada época, cada homem traz consigo a possibilidade, não de perceber um mundo eternamente dado, mas de formar sistemas que repousam em determinado inventário limitado de suas ações e dos conhecimentos humanos, comuns em dado momento a agrupamentos de indivíduos mais ou menos amplos. Todo espaço tem uma significação ao mesmo tempo individual e social, pois de outro modo seria incomunicável (FRANCASTEL, 1990, p.42).

O trabalho de Francastel intitula-se Pintura e sociedade e foi publicado pela primeira vez em 1951. Após discutir o nascimento do espaço plástico renascentista, o autor estuda a lenta elaboração do espaço plástico moderno que se deu a partir da destruição do espaço renascentista iniciada no Impressionismo. O espaço, como ressalta,

\footnotetext{
${ }^{10}$ Em A perspectiva como forma simbólica, de 1927, Erwin Panofsky (1993, p.34) escreveu: "Em certo sentido, a perspectiva muda o espaço psicofisiológico em espaço matemático. Renega as diferenças entre a parte da frente e a de trás, a direita e a esquerda, entre os corpos e o espaço que entre eles medeia (o espaço 'vazio'), e assim sendo, a soma de todas as partes do espaço e todos os seus conteúdos são congregados num 'quantum continuum' único. Deixa no esquecimento o facto de vermos não com um olho imóvel, mas com dois olhos, em movimento constante, que geram um campo de visão esferoidal. Não toma em consideração a diferença imensa que há entre a 'imagem visual', psicologicamente condicionada, através da qual tomamos consciência do mundo visível, e a 'imagem da retina', condicionada mecanicamente, que se imprime no olho físico".
} 
não é uma realidade em si, da qual somente a representação é variável segundo as épocas. O espaço é a própria experiência do homem. É tão-só porque séculos de convenção habituaram-nos a aceitar determinados signos expressivos utilizados na educação, com o fio de desenvolver simultaneamente nossas faculdades matemáticas e nossas faculdades visuais, que nos parece evidente que determinada perspectiva euclidiana fornece-nos, de modo espontâneo, a ilusão perfeita de realidade (Ibid, p.24).

Mesmo reconhecendo que o sistema ilusionista do Renascimento ainda satisfaz "a determinados hábitos intelectuais muito cômodos ao espírito", Francastel demonstra que “os inventores da representação perspectiva do espaço são criadores de ilusão e não imitadores, mais ou menos hábeis, do real"; o espaço renascentista "é uma mistura de geometria e de figuração simbólica onde o saber técnico está a serviço de crenças individuais e coletivas" (p.109).

Detendo-se na posterior destruição deste espaço plástico, Francastel considerou que foram os artistas impressionistas que introduziram novidades que viabilizaram a lenta elaboração de uma nova linguagem, reconhecendo, porém, a contribuição que os artistas românticos e realistas deram para a inovação dos temas. Para ele, o Impressionismo iniciante proporcionou "um novo estilo de figurar o espaço, mas não uma nova forma de vê-lo", posto que tornou possível a integração de novos elementos do espaço sensível, mas não subverteu "o sistema figurativo, nem tampouco a distância psíquica" (p.124). E a condição necessária para o surgimento de uma nova linguagem, de acordo com o autor, está justamente na mudança da distância psíquica. Por isso, observa que, enquanto no espaço Renascentista a preocupação dominante "tinha sido o inventário dos lugares e dos gestos de certa sociedade humana caminhado nas estradas da terra", na nova fase, "o fundamental é descobrir os segredos da vida. Percebeu-se que o mais misterioso é o que está mais perto, que o mais extenso espaço é o espírito humano e as relações do corpo com o espírito" (p.129). Nesse momento,

achou-se de novo mudada a célebre distância psíquica em função da qual as civilizações se diferenciam. O maior atrativo não são as aparências, os espetáculos, são os mecanismos. O homem queria desmontar todos os brinquedos. Logo perceberá que seu olho, no qual depositara tanta confiança, era incapaz de revelar-lhe de modo natural a posição dos membros de um cavalo em galope. Os 
grandes mistérios da natureza logo deixaram de ser conjuntos e longes para se tornarem em detalhes, e os mais próximos, finalmente, os que dizem respeito não ao objeto da sensação mas à sensação em si mesma, apreendida, por assim dizer, em estado bruto do órgão da percepção (Ibid, p.130).

À visão do Renascimento, “visão cúbica”, “distanciada do mundo”, Francastel opõe a visão moderna, "visão dirigida para a descoberta de um segredo nos detalhes".

Como destacamos, Pintura e sociedade foi publicado pela primeira vez em 1951. Seu autor nos alerta que a lenta elaboração de uma nova linguagem plástica, que começou no Impressionismo, continuava sob seus olhos. Focalizando o período do último meio século como um bloco, ou seja, sem uma abordagem detida em cada um dos diversos movimentos modernos, por contemporâneos, designava os artistas que partiram de Cézanne, Van Gogh e Gauguin e, por meio da observação da herança destes artistas para os mais novos, entendia que, "em certo sentido, a história do último meio século é a história da descoberta pelo grande público do balanço do impressionismo" (p. 192).

Uma das dificuldades da pesquisa de Francastel, como ele mesmo destacou, resultava do fato de que "na obra dos mais ousados, encontram-se partes que fatalmente pertencem à tradição, como existem na obra de Cézanne, de Van Gogh e de Gauguin numerosas obras que pertencem ao ideal impressionista", levando-o a considerar que ainda não se tinha chegado à fase de fixação do estilo. A esse respeito, posteriormente, o crítico Alberto Tassinari (2001, p.18), observando que "a arte moderna não possui estilos de época, como também não é ela própria um estilo de época", considerou que a variedade de movimentos artísticos lhe foi decisiva. Talvez a maior dificuldade de Francastel estivesse na contemporaneidade entre ele e seu objeto de estudo. Ele próprio ressaltou estar consciente de que julgava coisas que lhe eram muito próximas. Isso, porém, não o impediu de estudar a destruição do espaço renascentista (a partir da observação da permanência de elementos pertencentes aos 'gabaritos renascentistas" ${ }^{11}$ ao lado de outros inovadores) e a elaboração de uma nova linguagem (a partir da observação de que os tais gabaritos foram substituídos por uma figuração psicofisiológica). Em um dos exemplos abordados, Três árvores, de Estève, em suas palavras, "um excelente exemplo de notação figurada de uma sensação poli-sensorial

\footnotetext{
${ }^{11}$ Por exemplo, o da perspectiva linear e o do foco único de luz.
} 
[sic]", observou que, embora a técnica utilizada não estivesse tão distante da veduta quanto parecia à primeira vista,

o sistema de coordenação não repousa na quadriculação da tela de fundo, e sim em ligações emotivas e associações interiores. Além disso, as séries de sensações registradas não pertencem, em sua totalidade, à visão global do universo dotado $a$ priori de coordenadas regulares. A coerência só existe no plano da visão interior, em vez de se realizar no plano da matéria plástica. Portanto, pode-se de fato falar de uma nova ordem figurativa (Ibid, p.228).

Porém, duvidando se seu exemplo, no futuro, servirá de modelo para a arte de amanhã, ressaltou que ficava-lhe reconhecido por ter-lhe "revelado a possibilidade de construir um espaço baseado numa coordenação de imagens interiores e não mais na coordenação necessária dos fragmentos do objeto", pois, "o espaço do Renascimento também é feito de fragmentos diferenciais associados num sistema arbitrário - incluídos numa rede euclidiana, sujeita às regras únicas da terceira dimensão óptica projetada numa superfície plana". O que lhe parece incontestável é que a pintura contemporânea “já nos mostrou claramente a possibilidade material de introduzir, na figuração plástica imóvel, valores imaginativos e associativos de um novo tipo e já nos fez compreender em que consistiu o verdadeiro parti pris do Renascimento" (p.228). Sendo assim, considerou que com o despontar de um novo sistema de relações entre o percebido e o significado, baseado em outras estruturas permanente do espírito, o Renascimento estava indubitavelmente morto. "Daí em diante, caminhamos no sentido de um espaço dotado das dimensões poli-sensoriais [sic] de nossas experiências íntimas” (p.229). Atribuindo um lugar proeminente às especulações sobre os espaços curvos entre "as reflexões que permitiram que esse novo sistema de visualização baseado em associações inéditas de imagens se critalizasse um pouco", outro exemplo abordado foi $A$ dança, de Matisse. Discutindo-a, ressaltou que

a figuração do espaço deixa de ser uma descrição pitoresca e decorativa para se tornar um registro de gestos ou de ações elementares e de sensações experimentadas no plano da consciência, em função do acordo entre os diferentes sentidos [...]. Figuração espacial moderna, figuração espacial baseada na análise 
de reflexos, figuração psicofisiológica e não mais óptica no sentido euclidiano do termo (Ibid, p.231).

A importante contribuição do trabalho de Francastel para o estudo do espaço plástico foi destacada pelo crítico brasileiro Alberto Tassinari (2001, p.17) em O espaço moderno $^{12}$, ao considerar que "o projeto mais importante de uma compreensão positiva do espaço da arte moderna, apesar de suas conclusões tateantes, talvez tenha sido o de Francastel em Peinture et Société, de 1950”. Em seu trabalho, Tassinari avança na elaboração de um conceito para o espaço moderno, recusando o fim da arte moderna apregoado pelo debate em torno do pós-modernismo, conquanto reconhecendo a contribuição deste como “instância de debate". Para ele há dois momentos na arte moderna: a fase de formação e a fase de desdobramento ${ }^{13}$. Na fase de formação, a arte moderna ainda não pode ser pensada como formadora de uma espacialidade nova, pois seu espaço é naturalista e antinaturalista. $\mathrm{Na}$ fase de desdobramento, a arte moderna, chamada contemporânea, revolucionou o naturalismo, eliminando o que havia de prémoderno na arte moderna. Historicamente, o autor situa o começo da arte moderna por volta de 1870 e seu fim, ou o início da arte contemporânea, nos anos em torno de 1955. A distinção entre as fases é explicitada a partir da observação de que duas imagens célebres do Renascimento - a de que uma pintura "apresenta as formas das coisas vistas num plano tal como se fosse um vidro transparente" e a de que "deixa ver o que o pintor quis pintar através das margens retangulares da pintura como se elas delimitassem uma janela aberta" - não mais comparecem na fase de desdobramento. O primeiro exemplo analisado é a pintura Fool's Hause (1962), de Jasper Johns, ressaltando que nela "as coisas são vistas sobre um plano, não através dele - e não é um plano transparente, mas opaco. O que o pintor quer ou quis pintar também não é visto como se através de uma janela aberta, mas como se estivesse numa parede". Sendo assim, "se a imagem de uma pintura perspectiva é o vidro transparente de uma janela, o de uma pintura moderna é o anteparo" (p.29), mas, apenas quando a pintura moderna sempre toma a inteireza de sua

\footnotetext{
${ }^{12}$ Resultado de sua pesquisa de doutorado, defendida em 1997, no Departamento de Filosofia da Universidade de São Paulo.

${ }^{13}$ Francastel, após estudar o espaço renascentista, também estuda dois momentos da arte moderna: a fase de destruição do espaço plástico renascentista e a fase de elaboração de uma nova linguagem. No que tange a essas duas fases, se pensamos seu trabalho em relação ao de Tassinari, poderemos dizer que as duas fases estudadas por Francastel dizem respeito apenas à fase de formação da arte moderna estudada pelo crítico brasileiro.
} 
superfície à maneira de um anteparo, para Tassinari, a partir de $1955^{14}$, é possível então dizer que "ela já se encontra formada, que já está em sua fase de desdobramento, e o naturalismo, por sua vez, completamente destruído". A fase de formação é exemplificada com a pintura de Cézanne. Sobre o quadro do pintor A ponte de Maincy (1879-80), Tassinari escreveu: “Em parte ela é o vidro transparente através do qual se vêem as coisas. Em parte ela obstaculiza tal transparência pela trama das pinceladas". $\mathrm{Na}$ fase de formação, o plano da pintura, parte transparente, parte opaco, "é também em parte naturalista e em parte sua destruição" (p.30).

No artigo "As fontes da arte moderna", Giulio Carlo Argan (1987, p.49-50) considerou que "o movimento moderno na arte européia começou quando se percebeu que o Impressionismo mudou radicalmente as premissas, as condições e as finalidades do trabalho artístico". O novo objetivo reivindicado para o artista é o de "traduzir na obra de arte a sensação visual imediata, independentemente, e mesmo em oposição, de toda noção convencional da estrutura do espaço e da forma dos objetos". O valor da sensação é, por sua vez, um fato absoluto e autônomo, no qual o artista realiza "uma condição de plena autenticidade do ser, atinge na renúncia a qualquer noção habitual um estado de liberdade total, fornece o exemplo daquela que deve ser a figura ideal do homem moderno, livre de preconceitos e pronto para a experiência direta do real".

A par do valor da sensação na pintura moderna, Argan (1992, p.76), em Arte moderna, originalmente editado em 1970, considerou que, como o espaço construtivo da nova arquitetura de ferro, o espaço pictórico dos impressionistas "se determina pela relação entre seus elementos constitutivos".

Tassinari (2001), depois de tratar das duas fases da arte moderna; da generalização que os cubistas fizeram do emprego do contorno interrompido, que já se encontrava na última fase de Cézanne; da invenção da colagem; e da escultura moderna, define o espaço moderno do seguinte modo:

O espaço moderno, mais que um espaço de colagem ou um espaço manuseável, é um espaço em obra, assim como é dito de uma casa em construção que ela está em obras. Por meio da locução 'em obra', um espaço em obra possui um significado assemelhado, com a diferença de que uma obra de arte moderna, na

\footnotetext{
${ }^{14}$ Apesar desta data, Tassinari (2001, p.125-6) não deixa de ressaltar que há pinturas mais atuais "que possuem um espaço mais parecido com o da fase de formação da arte moderna" e que é principalmente em algumas pinturas figurativas contemporâneas que seu conceito de espaço em obra já formado "não se aplica bem", porém, ressalta: "A mudança nunca se dá para todos os artistas de um só golpe. A arte contemporânea não chega a ter cinqüenta anos”.
} 
grande maioria dos casos, não é algo incompleto, inacabado, mas algo pronto que pode ser visto como ainda se fazendo (TASSINARI, 2001, p.48-9).

O conceito elaborado pelo crítico, como ele mesmo destacou, "surge como um território do fazer, onde o feito pode mostrar-se ainda como que se fazendo", em intensidades crescentes da fase de formação para a fase de desdobramento, o que é compreensível, uma vez que, como esclarece, na fase de desdobramento, "um espaço em obra assume, para a pintura, a figura de um anteparo sobre o fundo do espaço do mundo em comum e, para a escultura, a de uma comunicação entre o corpo da obra e o espaço do mundo em comum" (p.51).

Articulando identidade e diferença no conceito do espaço em obra da arte moderna e da arte contemporânea, Tassinari assegura a continuação da arte moderna e, ao mesmo tempo, evita o equívoco entre ambas. Além disso, o conceito parece atender a uma reivindicação implícita à própria arte moderna - a de autonomia da pintura, enfatizada quando Maurice Denis, em 1890, no artigo "Definition du Neotraditionnisme", escreveu: "Lembrar que um quadro - antes de ser um cavalo de guerra, uma mulher nua ou uma anedota qualquer - é essencialmente uma superfície plana recoberta de cores combinadas numa dada ordem"15.

Herbert Read (s/d, p.15), no primeiro capítulo do livro A filosofia da arte moderna, arrolou diferentes aspectos que indiretamente relacionam-se com a arte do período moderno: o declínio do mecenato privado; o papel da crítica da arte na formação do gosto do público e a conseqüente dependência dos meios de publicidade por parte do artista; o progresso científico e industrial, que lançou produtos acessórios, teorias e invenções que influenciaram diretamente o significado técnico e social da arte. A influência mais significativa e permanente no desenvolvimento da arte apontada pelo crítico, porém, foi a invenção da fotografia e dos métodos fotográficos de reprodução que, entre outros efeitos, resultou na "distinção clara entre ilustração e interpretação", que tem implícita a distinção entre imagem e símbolo, "fundamental para compreender o movimento moderno em arte".

Ao discutir o sentido do termo "realidade" como "uma daquelas convenções que variam de época para época e são determinadas pela forma total de vida", em relação ao

\footnotetext{
${ }^{15}$ De acordo com Chipp (1988, p.90), “publicado originalmente em Art et Critique (Paris), 23 e 30 de agosto de 1890".
} 
presente - como informa em nota explicativa no final do livro, o ensaio foi originalmente escrito em 1949 -, observou:

atingiu-se um estado de relativismo na filosofia em que é possível afirmar que realidade é de facto subjetividade; isto significa que o indivíduo não tem outra escolha a não ser construir sua própria realidade, mesmo que isso pareça arbitrário e 'absurdo'. Esta é a posição dos existencialistas, e corresponde a uma posição no mundo da arte que requer uma decisão idêntica. A interpretação (ou mesmo 'imitação') da realidade era uma função válida do artista enquanto se considerou que a realidade geral e básica existia e só esperava a sua revelação. Desaparecido o sentido de segurança (o que equivale a dizer: destruído pela análise científica), a filosofia e a arte são leilões públicos nos quais a realidade mais aceitável é suscetível do mais alto preço (READ, s/d, p.18-9).

Discutindo a relação do artista com a natureza ao longo do tempo, Read considerou que o momento de surgimento do Impressionismo foi um corte total com o passado; o desenvolvimento de novas ciências teve sua aplicação na arte; a arte moderna é a continuação da linha científica do século XIX, mas, com o primeiro quadro cubista de Picasso, ocorreu um novo movimento, que se desdobra em dois: o cubismo analítico, que perpetua a atitude científica, a análise da estrutura da natureza, e o cubismo sintético, que, com Juan Gris, sugere que a obra de arte comece por uma realidade estética, ou seja, "por um modelo no espaço bidimensional da moldura do quadro". Nesse momento, "a origem da obra de arte deixa de ser a Natureza para ser a Idéia - algo de conceptual, de geométrico, de arquitectónico” (p.83). Nas palavras do autor,

Finalmente apareceram os artistas que disseram: Porquê [sic] a preocupação de introduzir elementos representativos na arte? Porque [sic] não deixar a estrutura geométrica ou arquitectónica falar por si, em termos de pura forma e cor? E começaram a pintar quadros e a esculpir materiais de acordo com estes princípios. Assim nasceu um novo tipo de arte chamada abstracta, construtivista, neoplástica e outros tantos nomes, mas todas estas variedades de arte abstracta concordam em repudiar uma noção de Arte de algum modo ligada à Natureza (Ibid, p.83). 
Observando que entre esses artistas há os que "nada têm a ver com a Natureza, simplesmente"; e os "que tentam representar o que é mais fundamental à Natureza nomeadamente as leis da harmonia inerentes à estrutura física do próprio Universo", Read considera que as teorias da arte, nos dois extremos deste desenvolvimento, "acentuam a liberdade do artista - o artista não é um escravo da Natureza, nem da ciência da Natureza. O seu espírito é livre - livre para exprimir-se não a si próprio (porque isso seria ainda uma forma de escravatura), mas uma visão nova [...]" (p.83).

Herschel Browning Chipp (1988, p.313), na introdução do capítulo "Neoplasticismo e construtivismo: arte abstrata e não-objetiva", do livro Teorias da arte moderna, entende "a idéia de que a pintura devia ser uma entidade absoluta, sem qualquer relação com os objetos do mundo visível e compor-se de formas totalmente abstratas que tinham sua origem na mente humana" como uma das conseqüências decorrentes da destruição cubista dos modos convencionais de representação. Porém,

nesses termos, a pintura tornava-se quase o oposto do cubismo analítico, que criara seu vocabulário decompondo as formas dos objetos naturais em configurações abstratas ou semi-abstratas, para reconstituí-las depois numa disposição dinâmica que, no entanto, ainda tinha ligações com os objetos originais. Essa pintura referia-se antes aos universais do que aos particulares, e por isso apelava sobretudo para a mente e só secundariamente recorria aos sentidos (CHIPP, 1988, p.313).

Para Argan (1992, p.302), no entanto, mesmo na fase inicial do cubismo analítico, "a finalidade era transformar o quadro numa forma-objeto que possuísse uma realidade própria e autônoma e uma função específica própria. Diante do quadro não é mais necessário perguntar o que ele representa, mas como funciona”. Nem mesmo perguntarse quem o pintou era importante, pois "a pergunta pressupõe o preconceito de que ela representa o mundo interior, a individualidade do artista". Observando que Picasso e Braque adotaram como 'motivos' objetos cuja forma é bem conhecida, considerou que a ênfase estava no mecanismo do quadro:

sua ação será tanto mais eficaz quanto menos identificáveis forem os objetos do quadro e maior for o choque do espectador desprovido: a quem afinal pretende-se ensinar a considerar a forma como parte integrante da realidade do objeto, 
fundamental tanto para seu conhecimento quanto para seu emprego. A tinta, já não sendo um meio de representação, mas possuindo uma realidade objetual por si só, como essência do quadro, apresenta-se em sua qualidade material, não raro misturada com areia para que se torne mais sólida; e a tinta é espalhada no quadro como se aplica um reboco, eliminando qualquer virtuosismo do toque e qualquer brilho da superfície. O espaço do quadro, enquanto espaço real, é capaz de acolher elementos retirados diretamente da realidade; uma das inovações técnicas mais sensacionais é, de fato, aplicação de pedaços de papel, de tecido etc. (collage). É uma maneira drástica de destruir o preconceito de que a superfície do quadro era um plano para além do qual se distinguia a invenção de um conhecimento: a pintura, a partir de agora, é a construção cromática sobre o suporte de uma superfície (ARGAN, 1992, p.303-5).

Voltando ao trabalho de Francastel (1990, p.38), observamos que, para este estudioso da arte, nem mesmo o artista renascentista foi um escravo da natureza, pois entendeu a pintura do seguinte modo: “o que está na tela plástica não é nem o real, nem o pensado, é um signo, isto é, um sistema de linhas e de manchas intermediárias que permite o intérprete, que deixa o artista atrair a atenção do espectador para um ponto do espetáculo eternamente móvel do universo". As artes representativas não traduziram o mundo, elas "sempre traduziram, em termos que elas pretendiam originais, idéias e aspectos de seu tempo. A diferença começa no capítulo referente aos meios e técnicas significativos" (p.115). O cubismo, "a primeira tentativa comum de expressão renovada do espaço plástico no século XX", é, a um só tempo, "realismo e representação arbitrária do mundo" (p.184-5). Com esta consciência, Francastel considera que Cézanne foi o pintor que conseguiu transferir "o problema do plano em que o tinham deixado os impressionistas - explorar o mundo através da análise ardente de todas as sensações - para aquele onde ainda se encontra colocado: substituir o antigo sistema de relações espaciais por um novo" (p.168). Detendo-se na obra "O castelo negro" (1904), de Cézanne, observou que ao invés de ter ocorrido a supressão do tema na pintura, deuse uma transferência:

O castelo negro é vagamente cúbico, mas não tem nada a ver com as casas que se escalonam nas telas clássicas. Não se trata mais de uma casa nem mesmo na acepção de Poussin ou de David. Não se trata mais de evocar a rua de uma cidade 
inserida nas malhas clássicas da perspectiva linear, nem muito menos de colocá-la como contexto de uma ação fictícia cujo sentido só há de surgir com facilidade para quem leu Ovídio ou Homero nos colégios humanistas [...]. O extraordinário é que nós também vemos esse Castelo negro e que ele desempenha um papel em nossas imaginações. Situamo-lo em um espaço simultaneamente concreto e imaginário. Entretanto ele representa também para nós uma alusão a alguns de nossos desejos ou de nossos objetos de orgulho (FRANCASTEL, 1990, p.169).

Francastel considera que "Cézanne criou nessa obra um objeto determinado em relação a certa civilização", impossível falar dela "com um banto ou um contemporâneo de Lourenço de Médici”, mas os que se escandalizam com ela entram no jogo tanto quanto os seus admiradores. "Mais uma vez, um signo nasceu em função de uma experiência técnica combinada com a experiência humana”, e, desta vez, o castelo se tornou elemento significativo "fora de qualquer anedota tradicional" (p.169).

Reconhecendo, porém, que no seu estudo dedicou pouco espaço a uma discussão sobre a arte abstrata, Francastel justifica sua atitude com a observação de que "a arte abstrata, bem como o surrealismo e o expressionismo, questionam muitos valores insuficientemente estudados para que seja possível atribuir-lhes, em alguns julgamentos categóricos, seu verdadeiro alcance". Apesar disso, ressaltou que a arte abstrata, "ao contrário do surrealismo e do expressionismo, que são aspectos da sensibilidade literária do tempo, constitui uma forma completa da expressão plástica", e demonstra-o na interpretação que faz da obra de Delaunay:

A obra de Delaunay mostra o modo como, com base na análise das propriedades espaciais da luz, é possível uma representação que exclua toda figuração de objetos no sentido positivo do termo. O objeto não desaparece, é criado arbitrariamente pelo estudo, como a equação na matemática. O maior erro está em acreditar que os fundamentos da arte abstrata estão em uma figuração gratuita de formas ou cores sugeridas a um artista por seu capricho ou de vagas aspirações naturalistas que não puderam expressar-se em valores estabelecidos. Não existe arte do informe, nem do puro ímpeto irrefletido. Em Delaunay há a procura de uma ordem que implica modificações, mas não destruição, das regras imperiosas da lógica das sensações (Ibid, p.220). 
A abstração assim entendida é a representação de uma ordem modificada pela lógica das sensações. Há nesse modo de ver a abstração um ponto de contato com o modo como Gilles Deleuze (2005, p.41), em Francis Bacon: Lógica de la sensación, obra originalmente publicada em 1981, entendeu que é possível ultrapassar a figuração (o ilustrativo ou narrativo) também em direção à figura, observando que foi o que fez Cézanne: "A esta vía de la Figura Cézanne le da un nombre sencillo: la sensación”. De acordo com Deleuze, a lição de Cézanne vai além dos impressionistas, a sensação não está nas impressões visuais, mas no corpo, mesmo que no corpo de uma maçã:

El color está en el cuerpo, la sensación está en el cuerpo, y no en los aires. Lo pintado es la sensación Lo que está pintado en el cuadro es el cuerpo, no en tanto que se representa como objeto, sino en cuanto que es vivido como experimentando tal sensación (eso que Lawrence, hablando de Cézanne, llamaba 'el ser manzanesco de la manzana') (DELEUZE, 2005, p.42).

Francis Bacon é, para Deleuze, um pintor que também consegue ultrapassar a figuração (ou representação como cópia de um modelo) em direção à figura, mas a figura é a forma referida à sensação e não a forma referida a um objeto que ela deveria representar. Daí, observando que a lógica da sensação é a lógica da pintura, ao estudar, por exemplo, os trípticos de Bacon, observa que "el propio ritmo se convierte en sensación, se convierte en Figura, según sus propias direcciones separadas, el activo, el pasivo y el testigo..." (p.78).

Nesse apanhado de idéias sobre a arte moderna, o que parece inegável, porém, é que, enquanto a pintura clássica deseja esconder a imitação, uma vez que o ilusionismo perspectivo, como bem colocou Tassinari (2001, p.57), “imita o espaço e coisas no espaço conforme o ponto de vista de um observador. Imita uma visão, algo de individual e intransferível”, a pintura moderna deseja justamente revelá-la, pois, conforme o conceito de Tassinari,

um espaço em obra imita o fazer da obra [...]. O espaço em obra é o imitante. O fazer da obra é o imitado. Entre o imitante e o imitado haverá semelhanças, ou não se justificaria o emprego da noção de imitação. As semelhanças que articulam 
o imitante com o imitado estão nos sinais expostos pelas obras das operações que a teriam feito (TASSINARI, 2001, p.57).

Em relação à pintura naturalista, Tassinari nos alerta: "pensar que o espaço e as coisas se resumem à visão que se tem deles é uma confusão que, não desfeita, confundirá também imitação e naturalismo”. Diferentemente, em um espaço em obra, "os sinais do fazer se mostram muito mais do que os artifícios empregados pelo naturalismo" que "necessita da ilusão e necessita portanto ocultar suas estratégias". No espaço em obra, "a obra expõe junto com o que comunica também passos para compreendê-la" (p.69). Por sinal do fazer, no que toca a um espaço em obra, o autor esclarece: "implica que ele não seja apenas o sinal de um fazer em geral, mas um sinal do fazer da obra na qual pode ser percebido" (p.72).

A ênfase na imitação por meio da exposição dos "sinais do fazer" reforça a autonomia da pintura e a liberdade do artista. Diante disso, aquele que olha a pintura moderna é convidado a ver mais do que o objeto, a natureza, a representação. E, nesse sentido, Kandinsky (2000, p.112), em Do espiritual na arte, ao discutir aspectos teóricos da arte moderna, reconhecendo a dificuldade para elaborar uma teoria perfeita e acabada, a criação de um "baixo contínuo da pintura”, pois naquele momento estávamos ainda "solidamente ligados à natureza; dela devendo extrair nossas formas (os quadros abstratos são raros)", considerou que toda a questão se resume em saber até onde pode ir a liberdade do artista de modificar a seu bel-prazer as formas e a que cores associálas. Discutindo os efeitos resultantes da cor vermelha a diferentes figuras (o céu, uma flor, uma roupa, um rosto, um cavalo, uma árvore) de um quadro, escreveu: “os elementos construtivos do quadro não devem ser tirados desse exterior, mas solicitados unicamente à Necessidade interna" (p.113-4). O autor critica o olhar habituado demais a ver a representação apontando para um olhar desejoso de sentir a vida interior da obra:

aquele que olha um quadro está, por outro lado, habituado demais a descobrir uma "significação", ou seja, uma relação exterior entre suas diferentes partes. Durante o período materialista, todas as manifestações da vida e, por conseguinte, também da arte, formaram um homem que é incapaz - sobretudo se se trata de um "entendido" - de se colocar simplesmente diante do quadro e que quer encontrar nele toda espécie de coisas (imitação da natureza, a natureza através do temperamento do artista, portanto, esse temperamento, um simples estado de 
alma, "pintura", anatomia, perspectiva, um ambiente, etc). Jamais busca sentir a vida interior do quadro, deixar que ela atue diretamente sobre ele (KANDINSKY, 2000, p.114).

Diante da obra moderna, o observador é convocado a sentir a obra a partir de seus elementos constitutivos, algo semelhante ao que Matisse disse ter feito diante dos afrescos de Giotto, em "Notas de um pintor": "Quando vejo os afrescos de Giotto em Pádua, não me importo em saber que cena da vida de Cristo tenho diante dos olhos, mas percebo instantaneamente o sentimento que ela emana, pois ela está presente nas linhas, na composição e na cor; o título só fará confirmar a minha impressão"16.

Ao falar das fontes da arte moderna, Argan (1987, p.18) considerou que "não há a possibilidade de uma corrente artística moderna que não leve em conta, mesmo que polemicamente, a nova concepção do mundo e do homem no mundo, que os impressionistas propuseram e, desde então, se procura aprofundar, explicar e levar às últimas conseqüências".

A importância da arte impressionista para a arte que veio depois pode ser observada de diferentes pontos de vista. Na crítica de Clemente Greenberg (1996, p. 164-5), por exemplo, quando, ao considerar que "a pintura de cavalete subordina o efeito decorativo ao dramático" e recorta a ilusão de uma cavidade em forma de caixa na parede atrás dela e, dentro desta, como uma unidade, organiza aparências tridimensionais, ressaltou que Monet, Pissaro, Sisley e os impressionistas ortodoxos atacaram esses princípios essenciais desta pintura. Porém, observando as conseqüências do impressionismo ortodoxo, considerou que, "independentemente de quanto a pintura se torne rasa, na medida em que suas formas sejam mantidas suficientemente diferenciadas em termos de luz e sombra, e sejam mantidas em equilíbrio dramático, ela permanecerá uma pintura de cavalete”. Para o crítico, era precisamente nesses pontos que a última prática de Monet ameaçava a convenção desta pintura e se tornava o ponto de partida para uma nova tendência: a pintura all-over.

Um outro exemplo da importância da arte impressionista para a arte moderna posterior pode ser observado na crítica de Argan $(1992,86)$ quando ele considera que o espaço da arte impressionista, como o espaço da arquitetura de ferro, se determina pela relação entre seus elementos constitutivos. Sobre a Torre Eiffel (1887-9), de GustaveAlexandre Eiffel, escreveu: "Não aceitando qualquer imagem espacial preconcebida,

\footnotetext{
${ }^{16}$ Publicado, segundo Chipp (1988, p.126), em “La Grande Revue, Paris, 25 de dezembro de 1908”.
} 
com a qual concordaria a imagem do edifício, Eiffel determina o espaço com os próprios signos da construção - pela primeira vez na arquitetura, cabe falar em signo em vez de forma". Detendo-se na arte moderna posterior, precisamente na "época do funcionalismo", de 1910 até aproximadamente a Segunda Guerra Mundial, observa que, nessa época, "diversas correntes pretendem definir a relação entre o funcionamento interno e a função social da obra de arte", entendendo o desenvolvimento da funcionalidade da arte como uma exigência que se "inclui na tendência geral da sociedade, já totalmente envolvida no ciclo econômico de produção e consumo, em realizar a máxima funcionalidade". Lembrando que Gauguin e os fauves também "consideravam a arte como atividade que se opõe ao trabalho alienante da indústria, mas lhe atribuíam como fundo e ambiente uma sociedade imaginária, primitiva, diferente da real", ressalta a necessidade de inserir o 'modelo' no contexto da função real da sociedade:

assim, procura-se reformar na estrutura o funcionamento interno e portanto o processo genético da operação artística, com o intuito de poder propô-la como modelo de função: não mais se reconhece um valor em si na obra de arte, mas apenas um valor de demonstração de um procedimento operativo exemplar, ou, mais precisamente, de um tipo de procedimento que implica e renova a experiência da realidade. Pode-se dizer, pois, que nesse período se realiza a transformação do sistema ou da estrutura da arte, passando de representativa a funcional (ARGAN, 1992, p.301).

Apresentando duas hipóteses para a arte moderna desse período (“1. a arte, como modelo de operação criativa, contribui para modificar as condições objetivas pelas quais a operação industrial é alienante"; "2. a arte compensa a alienação favorecendo uma recuperação de energias criativas fora da função industrial"), Argan considera que dessas duas hipóteses "partem os movimentos de caráter construtivistas: Cubismo, Blaue Reiter, Suprematismo e Construtivismo russos, De Stijl. Seu desenvolvimento é paralelo ao do funcionalismo ou racionalismo arquitetônico, do desenho industrial". Da tese da irredutibilidade e do individualismo absoluto, ele considera que "partem a Metafísica, o Dadaísmo e o Surrealismo”, mas acrescenta que também para essas correntes, “apesar da solução negativa, o problema central é o da relação indivíduo- 
sociedade, não há uma incompatibilidade ideológica entre os dois grupos, e sim uma possibilidade de relação e intercâmbio" (p.301-2).

Ortega y Gasset (2005, p.27), fazendo-nos pensar na imagem de um jardim visto de uma janela, observa que, se nosso intuito for ver o jardim, acomodaremos nosso olhar para que o raio da visão penetre o vidro sem deter-se e vá fixar-se nas folhas e folhagem. Quanto mais puro o vidro menos o veremos. Do contrário, se fizermos um esforço para ver o vidro, o jardim desaparecerá aos nossos olhos e dele só veremos uma massa de coisa confusa que parece grudada ao vidro. Portanto, "ver o jardim e ver o vidro da janela são duas operações incompatíveis: uma exclui a outra e requerem acomodações oculares diferentes". Esta passagem serve para Ortega observar a necessidade de acomodar nossa atenção na obra de arte em detrimento do jardim.

Usado a imagem do jardim, podemos dizer que a arte moderna da fase de formação, de diferentes modos alude a esse jardim que, pintado, em cada obra, torna-se notação figurada de uma sensação polissensorial, figura, corpo, sensação, ritmo, enfim, signo, dado a ver concomitantemente com o mecanismo que o constituiu. Perceber o signo é perceber o movimento a partir do qual ele se torna visível. 
À PROCURA DE...

\section{Perto do coração selvagem (1943)}

Perto do coração selvagem foi publicado pela editora $A$ Noite, em $1943^{17}$, no Rio de Janeiro, e laureado em 1944 com o prêmio Graça Aranha. A autora, uma jovem de 23 anos de idade, chamada Clarice Lispector, nascera em Tchetchelnik, durante viagem da família que, como outras famílias de judeus russos, dirigiam-se para a América em busca de refúgio. Inicialmente, a família morou em Maceió, depois Recife e, a partir de 1935, no Rio de Janeiro. No ano de 1943, além de publicar seu primeiro romance, Clarice naturalizou-se brasileira (12 de janeiro) e casou-se (23 de janeiro) com Maury Gurgel Valente, seu colega da faculdade de direito, aprovado em 1940 no concurso do Itamaraty e nomeado cônsul de Terceira Classe. Em decorrência do trabalho do marido, no dia 19 de janeiro de 1944, o casal partiu para Belém, de onde a escritora acompanhou, por meio de textos da imprensa jornalística e de correspondências trocadas com amigos e parentes, a recepção crítica de seu primeiro romance. Juntamente com o lançamento da obra iniciou-se em sua vida um período de constantes viagens pelo mundo - Libéria, Lisboa, Berna, Nápoles, Florença, Torquay, Londres, Paris e Washington. Em alguns destes lugares, esteve apenas de passagem, em outros, fixando residência.

A atividade de escrever começou durante a infância. Quando ainda morava no Recife, Clarice Lispector enviou histórias para a sessão infantil do Diário de Pernambuco, mas a publicação de seus textos ocorreu quando morava no Rio de Janeiro. Em uma passagem do depoimento ao Museu da Imagem e do Som (MIS) ${ }^{18}$ do Rio de Janeiro, gravado no dia 20 de outubro de 1976, com a participação dos amigos escritores Affonso Romano de Sant'Anna e Marina Colasanti, e do diretor do Museu, João Salgado, perguntada sobre quanto tempo trabalhou na revista Senhor, a escritora falou também sobre os contos da infância:

\footnotetext{
${ }^{17}$ De acordo com Inventário do Arquivo Clarice Lispector, organizado por Eliane Vasconcellos na Fundação Casa de Rui Barbosa, a primeira edição de Perto do Coração Selvagem aconteceu em 1944, porém, na biografia da autora realizada por Nádia Battella Gotlib (1995, p.173) lê-se: "os mil exemplares que apareceram em fins de 1943 esgotaram-se logo". No Instituto de Estudos Brasileiros - IEB, da USP, há um exemplar desta primeira edição, com capa de Santa Rosa, que pertenceu ao escritor Mário de Andrade. Nele é possível ler a dedicatória de 18 de dezembro de 1943 para o escritor e, no final da obra, a indicação do local e período de elaboração da mesma: "Rio, março-novembro de 1942".

${ }^{18} \mathrm{O}$ referido depoimento foi reproduzido nas obras: LISPECTOR, Clarice. A paixão segundo G.H. (Edição crítica). 2 ed. São Paulo: Edusp, 1996 e LISPECTOR, Clarice. Outros escritos: Clarice Lispector. Rio de Janeiro: Rocco, 2005.
} 
Enquanto durou a revista Senhor. Todo mês publicava alguma coisa minha... Muito antes, quando eu tinha quatorze para quinze anos, escrevi um conto e levei para uma revista que se chamava Vamos ler!, do Raimundo Magalhães Júnior. Então, fique lá, em pé. Eu era o que sou mesmo, uma tímida arrojada. Eu sou tímida, mas me lanço. Dei o conto para ele ler e disse: "É para o senhor ver se publica". Ele leu, olhou e disse: "Você copiou isso de alguém? Você traduziu isso de alguém?" Eu respondi que não e ele publicou. Depois houve um jornal chamado Dom Casmurro, para onde eu levei também algumas coisas, também sem nenhum conhecimento... Aí, eu cheguei lá e eles ficaram encantados, me acharam linda, que eu tinha a voz mais bonita do mundo e publicaram. Não pagaram nada, é claro (OE, p.142).

O volume Outros escritos - Clarice Lispector, organizado por Teresa Montero e Lícia Manzo, reúne textos inéditos, o depoimento concedido por Clarice Lispector ao MIS e os quatro primeiros contos da autora publicados: "O triunfo" ( 25 de maio de 1940, Pan); "Eu e Jimmy" (10 de outubro de 1940, Vamos ler!), "Trecho" (9 de janeiro de 1941, Vamos ler!) e "Cartas a Hermengardo" (30 de agosto de 1941, Dom Casmurro). Na introdução do primeiro capítulo, as organizadoras da obra informam:

Clarice Lispector estreou oficialmente na literatura aos 23 anos, com a publicação de Perto do coração selvagem, em 1943. Mas sua produção literária na verdade havia começado há mais tempo, com dezesseis contos publicados em jornais e revistas, e mesmo com alguns escritos nunca editados (MONTERO \& MANZO, 2005, p.9).

Sobre o contexto que antecede os anos 1940 na literatura brasileira, em Literatura e Sociedade, Antonio Candido (1985, p.126), ao abordar o modernismo brasileiro, destacou a existência de um novo momento da dialética entre o local e o universal em nossa cultura. A respeito do romance de 1930, observou que o romance intimista de Cornélio Pena e Lúcio Cardoso, bem como o social de Plínio Salgado e o dramático de Octávio de Faria exprimiam, "seja um inconformismo com o neo-realismo dos modernos, seja com a interpretação geralmente radical da sociedade".

Alfredo Bosi (1994, p.386), em sua História concisa da literatura brasileira, a respeito de nossa produção literária entre 1930 e 1945/50, escreveu que, "grosso modo, 
o panorama literário apresentava, em primeiro plano, a ficção regionalista, o ensaísmo social e o aprofundamento da lírica moderna [...] afinando-se lenta, mas seguramente, vinha o romance introspectivo, raro em nossas letras desde Machado e Raul Pompéia".

Registrar a presença do romance introspectivo no contexto dos anos 1930 é importante para que se entenda melhor a objeção de Luís Bueno (2001, p.251) àqueles que teimaram em ver, a partir da obra de Clarice Lispector, um momento inaugural em nossas letras, pois, para Bueno, uma visão mais abrangente sobre o romance de trinta mostra que a obra da autora "pôde se legitimar porque cabia num sistema que, embora não representasse propriamente o mainstream da nossa literatura de ficção, era um sistema atuante e não marginalizado como se tende a ver hoje".

Em relação à crítica literária brasileira, Wilson Martins (2002, p.31) observou que os anos 1940 marcavam o momento em que se iniciava "entre nós, em plano verdadeiramente universitário, os estudos sistemáticos de Literatura Brasileira", com a ocorrência de alguns concursos acadêmicos célebres, como o de Alceu Amoroso Lima, na Faculdade de Filosofia do Rio, em 1945, resultando na publicação das obras $O$ crítico literário e Estética literária.

Randal Johnson (1985, p.176), com base nos conceitos de Pierre Bourdieu, discutiu a dinâmica do campo literário brasileiro dentre 1930 e 1945 a partir da análise das relações entre os intelectuais modernistas e o Estado, da expansão da indústria editorial, da luta pela definição legítima do trabalho literário e da automatização do campo literário no Brasil. Para Johnson, a "autonomização do campo literário brasileiro, pelo menos dentro daquelas linhas delineadas por Bourdieu para o território francês, começou, quando muito, por volta de 1940". O modernismo brasileiro "institucionalizou-se durante e dentro do Estado Novo, na medida em que a maioria dos modernistas foi incorporada ao aparato do Estado" (p.172). Entre os diferentes exemplos citados pelo crítico para demonstrar que, nesse período, a cultura e a política tornaram-se inseparáveis, encontram-se as organizações que respaldavam diversas formas de produção cultural como o Serviço Nacional de Teatro (SNT), o Instituto Nacional de Cinema Educativo (Ince) e o Instituto Nacional do Livro (INL), criados em 1937. Abundam, ainda, os exemplos da presença dos intelectuais no aparato do Estado, exercendo cargos de direção em setores como o Departamento Estadual de Imprensa e Propaganda (Deip), o Serviço do Patrimônio Histórico, os jornais governistas $A$ manhã e $A$ noite, ou em outros cargos ligados ao governo. Ele interpreta que 
a contribuição dos intelectuais para o projeto cultural do Estado, não importa se direta ou indiretamente, serviu para reforçar e reproduzir a posição do campo literário/intelectual dentro do campo mais amplo de poder e para reforçar o papel do Estado como agente de legitimação intelectual (JOHNSON, 1985, p.172).

Confirmando as palavras de Johnson sobre a participação dos intelectuais brasileiros no aparato do Estado, vale observar que em 1941, antes da publicação de seu primeiro romance, Clarice Lispector trabalhou na Agência Nacional, pertencente ao Departamento de Imprensa e Propaganda (DIP), ao lado de nomes como o de José Conde, Antônio Callado e Lúcio Cardoso. Posteriormente, a partir de fevereiro de 1942, trabalhou no jornal $A$ Noite, nas palavras de Teresa Cristina Montero Ferreira (1999, p. 85), "um dos mais tradicionais do Rio de Janeiro, fundado em 1911” e encampado, na década de 1940, pelo governo federal, transformando-se "num órgão de elogio obrigatório ao governo".

Entre os fatores mais importantes destacados por Randal Johnson para a autonomização do campo literário brasileiro naqueles anos encontram-se a criação das universidades na década de 1930 "e a conseqüente formação de um grupo de críticos profissionais que começou, nos anos 1940, a rejeitar o impressionismo e a se tornar mais especializado em sua abordagem da literatura". Nesse sentido, o autor concorda com Wilson Martins quanto ao início dos estudos sistemáticos de literatura brasileira no país, observando que, naquele período, se consolidou entre nós uma sociedade urbanoindustrial, concomitante ao surgimento da "diversificação das formas culturais e do público através do crescimento e da modernização da indústria cultural” (p.179), em especial o cinema, o rádio, as revistas e a indústria editorial, acrescentando a tudo isso a derrota do nazi-fascismo, na Europa, e o fim do Estado Novo, no Brasil.

Sobre a definição legítima da prática literária, Johnson observou que antes dos anos 1940 a crítica era dominada "pelo rodapé impressionista", definida como a crítica jornalística exercida por um crítico que ocupava espaço fixo no jornal. Os críticos citados são Tristão de Ataíde, nos anos 1920, e Álvaro Lins, nos anos 1940. A respeito do poder desses críticos, destacou: "um poder que funcionava também como uma forma de censura não-intencional talvez, já que críticos menores se intimidavam e, por conseguinte, relutavam em emitir suas opiniões" (p.174-5). Para Johnson, o campo literário ou crítico reproduzia os debates ideológicos da sociedade como um todo, exercendo um princípio de legitimação "inteiramente externo à própria obra”. Questões 
de forma literária "emergem apenas de vez em quando e mais raramente ainda entre aqueles envolvidos com a paixão no debate". Citando palavras de Lúcio Cardoso, Marques Rebelo e Jorge Amado sobre a forma do romance, ressalta: "o que está em jogo aqui (e os exemplos poderiam se multiplicar de forma indefinida) é a definição legítima da obra de arte ou, neste caso, do romance” (p.175). E esta é uma das questões importantes que o primeiro romance de Clarice Lispector, contemporâneo do processo de autonomização do campo literário brasileiro, no sentido discutido por Johnson, porá em pauta nas discussões sobre a sua narrativa.

O primeiro romance da escritora, como informou a biógrafa Ferreira (1999, p.95), foi apresentado a Álvaro Lins, diretor da coleção Joaquim Nabuco da editora Amerique Edite, pelo jornalista Chico Barbosa. Lins "ficou impressionado pelo livro", mas, indeciso quanto ao valor, consultou Otto Maria Carpeaux, que "não gostou do que leu". A editora José Olympio recusou-o, e o livro acabou sendo publicado pela editora $A$ Noite, filiada ao jornal onde Clarice trabalhava, com um acordo no qual a editora arcava com as despesas da publicação a ser realizada no final de 1943, mas a autora abria mão dos direitos autorais.

Ao ser publicado, Perto do coração selvagem não passou despercebido pelos críticos, muito pelo contrário. As críticas de Sérgio Milliet, Álvaro Lins e Antonio Candido, entre outras, publicadas no calor da hora, são, com freqüência, recuperadas por quem estuda a obra da escritora, e já nos dão mostra de uma crítica que não se restringe à impressão que a obra causa no leitor. A ressalva disso recai sobre a crítica de Álvaro Lins, mais impressionista e tendendo para a crítica de influência, porém, contendo observações importantes sobre a narrativa clariciana, prejudicadas por um ponto de vista apegado ao paradigma do romance realista tradicional.

Ao investigar as possibilidades de objetivar o horizonte de expectativas do público brasileiro em 1944, Olga de Sá (1979, p.293), primeira estudiosa a reunir uma fortuna crítica sobre a obra de Clarice Lispector, ressaltou: "não temos dados precisos para saber o que o livro representou para o público, em geral”. Um dos indícios disponíveis, para Olga de Sá, encontra-se na nota explicativa presente na segunda edição da obra, lançada apenas em 1963 pela editora Francisco Alves:

Trata-se de uma reedição oportuna e necessária, já que lançado há cerca de vinte anos, em tiragem pequena, este Perto do Coração Selvagem, tido por muitos 
como a obra-prima de Clarice Lispector, é completamente desconhecido dos leitores de hoje (Apud SÁ, 1979, p. 293).

A respeito da recepção da obra de Clarice Lispector, o crítico Benedito Nunes (1989, p.63) observou duas fases distintas. A primeira, em 1944, com a publicação de Perto do coração selvagem, "conhecida apenas entre críticos e escritores"; e a segunda, “a partir de 1959, com o aparecimento do livro de contos Laços de família, que conquistou o público universitário e despertou o interesse pelos outros romances da autora [...]". O prestígio dessa segunda fase, à qual pertencem as obras A legião estrangeira (1964) e Felicidade clandestina (1971), secundado, de acordo com Nunes, pela presença de suas crônicas no Jornal do Brasil, "alimentou-se da impressão desconcertante que produziria A paixão segundo G.H. (romance), também em 1964, e da mágica atração que se desprendia da figura humana da ficcionista [...]”. Com a morte da escritora, Nunes sugere que se pode pensar em uma terceira fase, "condicionada às peculiaridades de dois livros", A hora da estrela (1977) e Um sopro de vida (1978), observando que o primeiro não mais exibe o rótulo de romance e o segundo traz $o$ subtítulo de Pulsações.

$\mathrm{O}$ crítico Antonio Candido, durante uma comunicação intitulada "O papel do Brasil na nova narrativa", de 1979, reportando-se ao romance Perto do coração selvagem, ressaltou algo que sintetiza muito bem a importância da obra de Clarice Lispector para a história da literatura brasileira:

Clarice mostrava que a realidade social ou pessoal (que fornece o tema), e o instrumento verbal (que institui a linguagem) se justificam antes de mais nada pelo fato de produzirem uma realidade própria, com a sua inteligibilidade específica. Não se trata mais de ver o texto como algo que se esgota ao conduzir a este ou àquele aspecto do mundo e do ser; mas de lhe pedir que crie para nós o mundo, ou um mundo que existe e atua na medida em que é discurso literário. Este fato é requisito em qualquer obra, obviamente; mas se o autor assume maior consciência dele, mudam as maneiras de escrever e a crítica sente necessidade de reconsiderar os seus pontos de vista, inclusive a atitude disjuntiva (tema $a$ ou tema $b$; direita ou esquerda; psicológico ou social). Isto porque, assim como os próprios escritores, a crítica verá que a força própria da ficção provém, antes de tudo, da 
convenção que permite elaborar os "mundos imaginários" (CANDIDO, 2003, p. 206).

O Diário Crítico de Sérgio Milliet (1981, p. 28), que contém artigos do autor publicados na imprensa durante o ano de 1944, apresenta nos escritos do dia 15 de janeiro a declaração da satisfação que sentiu ao fazer a nova descoberta que Perto do selvagem the proporcionou. Sua crítica é uma leitura atenta às personagens, principalmente à protagonista. No começo, ao citar uma passagem da obra, observa no "estilo nu" a "riqueza psicológica". Mas é pela personagem Joana que Milliet mais se encanta, destacando nela 'as observações 'cristalinas e duras', a capacidade introspectiva, a coragem simples com que compreende e expõe a trágica e rica aventura da solidão humana". Considera Joana "de uma sensibilidade complexa e um poder expressivo inato que frisa a magia incantatória”. Em uma palavra, considera Joana poeta, e justifica-se:

porque para essa heroína de olhos fixos nos menores, nos mais tênues movimentos da vida, não há uma realidade, mas várias; e todo o seu drama nasce mesmo da contradição, do antagonismo de seu mundo próprio, cheio de significados específicos, com os mundos alheios, ou mais vulgares ou impenetráveis (MILLIET, 1981, p.28-9).

No romance, "a desimportância relativa dos demais personagens", "apenas esboçados", segundo Milliet, se justifica pela observação de que a Joana não é dada "a possibilidade de diluição, de comunhão integral" (p.29). O livro é tido como um "diálogo interior" que "começa no isolamento da menina sozinha no mundo irreal dos adultos". Os principais acontecimentos da narrativa são resumidos do seguinte modo pelo crítico: "Numa técnica simultânea de capítulos ajustados desordenadamente, vemos Joana crescer com uma tia incompreensiva, casar, ter uma rival, enganar o marido por vingança, sumir afinal na espectativa [sic] de uma vida refeita" (p.30). Para Milliet, a linguagem, "fácil, poética", não cai "no hermetismo nem nos modismos modernistas". É uma linguagem "pessoal, de boa carnação e musculatura, de adjetivação segura e aguda, que acompanha a originalidade e a fortaleza do pensamento, que os veste adequadamente". Não se trata, porém, de pensamento de "fácil vestir", "pois se apresenta sempre de uma qualidade muito pura, e qualquer imagem em falso, demasiado brilhante, 
qualquer exibicionismo, mesmo poético, o deturpariam" (p.30). Houve "harmonia preciosa e precisa entre a expressão e o fundo", que a "autora alcançou magistralmente", e só observadas "até agora em certos escritores franceses e ingleses, num Gide, num Morgan [...]" (p.30).

Após uma breve síntese das idéias discutidas nas primeiras linhas de seu texto, ressaltando um pouco mais que Joana "se preserva da diluição nos outros com temor assustado de perder a sua própria vida", Milliet observa que o amadurecimento sexual dificultará a evasão, pois:

ligar-se a um homem já constitui mais do que uma solução exterior. A prisão da carne fecha-se por dentro da gente, não por fora; e a partir de um certo momento o ato de possuir se enleia inextricavelmente ao ato de ser possuído. Ocorre uma simbiose que passa a moldar a vida normal da maioria, mas que para os indivíduos como Joana não vai sem luta, sem resistência, sem afirmações de independência, sem revoltas, é dolorosa (Ibid, p.30-1).

A solução apontada por Milliet para essa luta no romance "está na preservação do espírito" que há na imaginação apreendendo o futuro do presente, mas, por outro lado, há o perigo "do afastamento gradativo da vida sensual, na construção lenta mas segura de um mundo próprio, de um mundo dentro do qual o presente perde pouco a pouco sua forma, do qual o presente se ausenta, ou se confunde com o passado e o futuro", comparável "à filosofia do personagem de Lenormand para o qual presente, passado e futuro coexistiam" (p.31). Para Joana, "entregar-se é renunciar, é morrer. Joana, animalmente viva, se recusa a morrer", vindo a sentir que vida e morte "são uma só e única coisa" ao partir para a viagem. Quanto às demais personagens do romance, destaca o marido, como um intelectual "preocupado por demais consigo mesmo", e o amante, como aquele que dá um sentido ao destino de Joana e "lhe abre uma nesga de horizonte. É a ele de resto que ela conta mais detalhadamente seu prazer inventivo" (p.32). Na conclusão, elogia o "romance introspectivo" da autora:

A obra de Clarice Lispector surge no nosso mundo literário como a mais séria tentativa de romance introspectivo. Pela primeira vez um autor nacional vai além, nesse campo quase virgem de nossa literatura, da simples aproximação; pela primeira vez um autor penetra até o fundo a complexidade psicológica da alma 
moderna, alcança em cheio o problema intelectual, vira no avesso, sem piedade nem concessões, uma vida de recalques (Ibid, p.32).

Álvaro Lins (1963, p.186-7), no artigo “A experiência incompleta: Clarisse (sic) Lispector", de fevereiro de 1944, estabelece uma relação "genética", ao enfatizar a presença de traços da personalidade da autora na obra, e recorre à crítica de influência, ao apontar para a técnica de James Joyce e Virgínia Woolf. Destacando a diferença entre uma literatura de autoria masculina e outra feminina, a segunda considerada como possuidora de maior "pessoalismo" porque "as mulheres dispõem quase sempre de um potencial de lirismo que precisa dos livros pessoais de confissões, das obras capazes de as situar como centro do mundo", elogia o impessoalismo aparente de Flaubert e da escola realista, considerando que "a escola realista e a escola naturalista não foram muito propícias às mulheres escritoras, salvo um ou outro caso de inteligência andrógena". Ressalta que o fenômeno do narcisismo é feminino em seu caráter essencial, mas não deixa de notar que não é lícito "insistir demais nessa circunstância extraliterária”. Porém, após ater-se, ainda, no caráter do lirismo feminino, observa que “o lirismo, a visão poética do mundo, não exclui o realismo", mesmo porque, como sugere, falar de romance moderno é falar de lirismo. Cita, então, a obra de Proust como "a descoberta de um novo mundo psicológico", e a de Virginia Woolf como um exemplo do "entrelaçamento do lirismo com o realismo", ressaltando que "não há contradição entre o lirismo e a visão aguda do mundo" (p.187).

O romance de Clarice Lispector é tido como a primeira experiência que se fez no Brasil "do moderno romance lírico", que Lins denominou também de romance "de realismo mágico", conceituando-o:

Define-se pela apresentação da realidade num caráter de sonho, de superrealidade. A realidade não fica escondida ou sufocada, porém é elevada para os seus planos mais profundos, mais originais, nas fronteiras entre o que existiu de fato e o que existiu na imaginação [...]. Eliminam-se as fronteiras e a fusão e a confusão dos dois mundos gera uma estranha realidade ficcionista (LINS, 1963, p. 188).

Porém, mesmo considerando este "realismo mágico", ainda é no paradigma de romance realista tradicional que irá se apoiar para criticar a estrutura da narrativa 
clariciana ao destacar que, na narrativa de Clarice Lispector, "o gesto, tantas vezes repetido, de apelar para os recursos da poesia" está ligado à falta dos "recursos da estruturação ficcionista". O elogio maior é dedicado à primeira parte da obra, “construída em termo de fícção". Da segunda parte destaca:

É certo que aí estão os melhores capítulos do livro - 'A Pequena família' e 'O Encontro com Otávio', sem que nenhum dos dois, no entanto, supere o ' $\mathrm{O}$ Banho', que é, a meu ver, o seu momento culminante - conquanto o espírito do romance comece a desgastar-se de modo irremediável (LINS, 1963, p.190).

Considera que Clarice Lispector, não tendo conseguido resolver os problemas em termos de ficção, não soube "como acabar o livro", que "ficou inacabado e incompleto como romance" (p. 190). No seu entender, a principal dificuldade da escritora foi quanto à solução do problema de tempo e espaço, "o centro da forma do romance", pois, sobre o tempo, mesmo elogiando o "efeito admirável na arte de inserir o passado no presente", de modo negativo, ressalta: "o livro causa mais impressão por certas situações isoladas do que pelo conjunto"; e sobre o espaço, voltando-se para a representação da realidade exterior na narrativa, aponta que falta a esta, como romance, "tanto a criação de um ambiente mais definido e estruturado quanto a existência de personagens como seres vivos", destacando que apenas Joana "tem uma existência real". Ao final, sobre o monólogo interior, "a reconstituição do pensamento em vocábulos", conclui: nessas ocasiões a "luta com as palavras" se torna "ainda mais dramática", e aí a escritora "se sente mais tentada para o verbalismo" (p.191).

Em Vários escritos, de Antonio Candido (1970), encontra-se o artigo "No raiar de Clarice Lispector", que corresponde a dois textos publicados pelo crítico na Folha da Manhã em 1944: "Língua, pensamento, literatura", de 25 de junho, e "Perto do coração selvagem", de 16 de julho. Como sugere o título do texto publicado a 25 de junho, o crítico inicia discutindo a questão do aprofundamento da expressão literária em nossas letras. Antes de abordar o romance de Clarice Lispector, apresenta uma síntese do que é necessário para que a nossa literatura possa ser encarada do "ângulo das produções feitas para permanecer":

Para que a literatura brasileira se torne grande, é preciso que o pensamento afine a linguagem e a língua sugira o pensamento por ela afinado. Uma corrente dupla, de 
que saem as obras-primas e sem a qual dificilmente se chega a uma visão profunda e vasta da vida dentro da literatura (CANDIDO, 1970, p.126).

Antonio Candido discute o que entende por "a grande literatura" e começa por destacar que inexiste nos romances que se publicam todos os dias entre nós "a verdadeira exploração vocabular e a verdadeira aventura da expressão", ressaltando que "raramente é dado encontrar um escritor que, como o Oswald de Andrade de João Miramar, ou o Mário de Andrade de Macunaíma, procura estender o domínio da palavra sobre regiões mais complexas e mais inexprimíveis, ou fazer da ficção uma forma de conhecimento do mundo e das idéias" ${ }^{\prime 19}$. Seu texto, sendo conciso, traz na introdução importantes aspectos sobre sua compreensão do fenômeno literário, necessários para que mais à frente seu leitor compreenda a surpresa que teve "ao ler o romance diferente que é Perto do coração selvagem”. Nesse sentido, ao deter-se no romance de Clarice Lispector, observará aspectos apresentados na introdução:

a autora (ao que parece uma jovem estreante) colocou seriamente o problema do estilo e da expressão. Sobretudo desta. Sentiu que existe uma certa densidade afetiva e intelectual que não é possível exprimir se não procurarmos quebrar os quadros da rotina e criar imagens novas, novos torneios, associações diferentes das comuns e mais fundamente sentidas [...]. Para ela, como para outros, a meta é, evidentemente, buscar o sentido da vida, penetrar no mistério que cerca o homem. Como os outros, ela nada consegue, a não ser esse timbre que revela as obras de exceção e que é a melhor marca do espírito sobre a resistência das coisas (Ibid., p. 128).

Atendo-se à questão do gênero romanesco, observa que hoje "os romances são mais universalistas", não cabendo, portanto, as delimitações que os classificam, mas sugere o termo "romance de aproximação", pois o campo desta narrativa ainda é a alma, são as paixões, mas há "uma tentativa de esclarecimento através da identificação do escritor com o problema, mais do que uma relação bilateral de sujeito-objeto". Quanto ao

\footnotetext{
${ }^{19}$ Observa-se que há no início do texto de Antonio Candido uma aproximação entre Lispector e os autores Mário e Oswald de Andrade. O mesmo correu no artigo "Tema e técnica", de Sérgio Buarque de Holanda (1989), publicado pela primeira vez em 1950 no Diário Carioca. Para Holanda, a narrativa de Clarice Lispector, filiada à prosa de vanguarda modernista, ultrapassa o experimentalismo da vanguarda, pois as verdadeiras possibilidades de renovação da arte do romance ainda se acham nos rumos que seus romances apontaram.
} 
ritmo, é "um ritmo de procura que permite uma tensão psicológica poucas vezes alcançada em nossa literatura contemporânea". Quanto à linguagem, "os vocábulos são obrigados a perder o seu sentido corrente para se amoldarem às necessidades de uma expressão sutil e tensa, de tal modo que a língua adquire o mesmo caráter dramático do entrecho". Quanto à organização dos acontecimentos narrados, observa que a narrativa se desenvolve em dois planos, alternando o passado com o presente da protagonista, e que todos estes processos são conscientes e escolhidos, correspondendo à atmosfera do romance que "parece dar menos importância às condições de tempo e espaço do que a certos problemas intemporais, encarnados pelos personagens". Ao deter-se na análise da protagonista, destaca importantes aspectos do romance, pois percebe na existência presente de Joana "uma atualidade bastante estranha", que o impede de "saber se a narrativa se refere a algo já passado ou em vias de acontecer” (128-9). Sua análise privilegia o capítulo “...O Banho...”, sugerindo que nele talvez se possa compreender Joana como a personagem central do romance, aproximando-a do poeta:

Este romance é uma variação sobre o suplício de Tântalo. Joana passeia pela vida e sofre, sempre obsecada [sic] por algo que não atinge. Move-se perenemente entre aquelas "formas vãs e as aparências", de que o poeta julgou se ter libertado; e, como ele, apenas entrevê a zona mágica onde tudo se transmuda e a convenção dos sentidos cede lugar à visão essencial da vida. "Eu posso tudo". A pobre Joana nada pode, como nós. Mas possui uma virtude que nem a todos é dada: recusar violentamente a lição das aparências e lutar por um estado inefável, onde a suprema felicidade é o supremo poder, porque no coração selvagem da vida podese tudo o que se quer, quando se sabe querer (Ibid., p.129-30).

Mas, Candido também considera que, diferente de Tântalo, para quem tocar o alvo fugidio era desespero, para Joana "nisso residia a própria razão de ser da vida e, portanto, a sua glória, a sua esplêndida unicidade". Para o crítico, Joana não está completamente isolada, ela vive em contato com outras pessoas, principalmente com o seu marido, e, "como a vida, o romance de Clarice Lispector é um romance de relação". A narrativa, por outro lado, a partir de certo ponto, passa a "entrar por outros destinos a dentro" (p. 130). Sua leitura de Perto do coração selvagem busca entender a construção formal e, ao final, conclui que o romance de Clarice Lispector, sendo a primeira experiência da escritora, já é uma nobre realização. 
Interessante notar que Clarice Lispector parece ter lido e concordado com Antonio Candido sobre a importância do pensamento afinar a linguagem e a língua sugerir o pensamento por ela afinado, pois no texto "Literatura de vanguarda no Brasil", de 1963, sobre língua, pensamento e literatura, a autora escreveu:

Nossa língua ainda não foi profundamente trabalhada pelo pensamento. 'Pensar' a língua portuguesa do Brasil significa pensar sociologicamente, psicologicamente, filosoficamente, linguisticamente sobre nós mesmos. Os resultados são e serão o que se chama de linguagem literária, isto é, linguagem que reflete e diz, com palavras que instantaneamente aludem a coisas que vivemos; numa linguagem real, numa linguagem que é fundo-forma, a palavra é na verdade um ideograma (OE, p. 106).

A autora ressaltava o sentido imanente da linguagem literária ao considerar que esta "diz com palavras que aludem", "numa linguagem real", "fundo-forma", "um ideograma".

Pode-se dizer que desde a recepção crítica de seu primeiro romance, um dos problemas apontados na obra da escritora relaciona-se às expectativas dos leitores quanto aos paradigmas do romance convencional. Para o leitor cujo romance de Clarice Lispector frustrava as expectativas modeladas pelas convenções antigas, sua obra apresentava defeitos; para aquele interessado em buscar sentidos para a configuração temporal que apresentava, sua obra trazia implicações mais profundas para a arte de narrar. A esse respeito, é importante retomar as palavras de Paul Ricoeur (1995) sobre a configuração do tempo na narrativa, ao ressaltar que

uma coisa é a rejeição da cronologia; outra, a recusa de qualquer princípio substitutivo de configuração: não é pensável que a narrativa possa dispensar qualquer configuração. O tempo do romance pode romper com o tempo real: é a própria lei da entrada na ficção. Mas ele não pode deixar de configurá-lo segundo novas normas de organização temporal que sejam ainda percebidas pelo leitor como temporais, graças às novas expectativas relativas ao tempo da ficção [...] (RICOEUR, 1995, p.41). 
O romance Perto do coração selvagem está dividido em duas partes. Cada capítulo recebe um título. O ritmo temporal entrecortado da narrativa, como observou Benedito Nunes (1989, p.22), “alterna ou no mesmo episódio ou em episódios distintos, como sucede na primeira parte do romance, o passado com o presente" da personagem Joana. A temporalidade do romance,

que acompanha, nessa parte, a ordem associativa e evocativa das vivências, substitui a unidade biográfica externa pela unidade múltipla da duração que o dinamismo da consciência articula. Os estados subjetivos, com as qualidades próprias, distribuem-se em cadeias autônomas, que fixam instantâneos de presente ou passado e correspondem a episódios completos (NUNES, 1989, p.22).

Os episódios da primeira parte podem ser lidos como episódios completos, como observou Benedito Nunes, mas estão relacionados com outros instantes desta narrativa que tem no movimento circular e ondulatório um aspecto constitutivo importante da forma. Marca deste aspecto é a presença de reticências em alguns títulos da primeira parte: “O Pai...”, “...Um Dia...”, “...A Tia...”, “...O Banho...”.

No segundo capítulo da obra, "O dia de Joana", Joana é uma mulher adulta, casada com Otávio, e da qual a narradora nos diz que ao sentir que o marido saíra de casa transformava-se: "Concentrava-se em si mesma e, como se apenas tivesse sido interrompida por ele, continuava lentamente a viver o fio da infância, esquecia-o e movia-se pelos aposentos profundamente só" (PCS, p.25). Esta passagem nos aponta o primeiro capítulo, “O Pai...”, que traz a protagonista Joana ainda criança, como fruto da imaginação de Joana agora adulta. $\mathrm{O}$ sujeito que narra, às vezes, confunde-se com a personagem Joana adulta, que vive momentos presentes e imagina momentos passados, ocorrendo aquilo que Rosenfeld (1996) percebeu em relação à radicalização do monólogo interior: o narrador submergindo na própria corrente psíquica da personagem. Em alguns instantes, a narradora, muito próxima da consciência da personagem adulta, relevando que a narrativa é produto do pensamento desta, expõe reflexões sobre o narrar, como ocorre no segundo capítulo: "Sim, ela sentia dentro de si um animal perfeito. Repugnava-lhe deixar um dia esse animal solto. Por medo talvez de falta de estética. Ou receio de alguma revelação... Não, não, - repetia-se ela - e preciso não ter medo de criar (PCS, p.25-6, Grifo nosso). 
Benedito Nunes (1989, p.29), no capítulo em que analisa os romances Perto do coração selvagem e $O$ lustre, intitulado "A narrativa monocêntrica", conceito utilizado para tratar da "narrativa desenvolvida em torno de um centro privilegiado que o próprio narrador ocupa", resume: "Em suma, a posição do narrador se confunde ou tende a confundir-se, nessa forma, com a posição da personagem”. Mais à frente, no capítulo intitulado "O movimento da escritura", esclarece mais um pouco o conceito: "o $\mathrm{eu}$ narrador subsidia a reflexão das personagens, mas delas se retrai a todo custo, evitando consumar a identificação latente ao aspecto monologal da narrativa" (p.151).

A passagem abaixo corresponde ao início da narrativa:

A MÁQUINA DO PAPAI batia tic-tac... tac-tac-tac... O relógio acordou em tindlen sem poeira. O silêncio arrastou-se ZZZZZZ. O guarda-roupa dizia o quê? roupa-roupa-roupa. Não, não. Entre o relógio, a máquina e o silêncio havia uma orelha à escuta, grande, cor-de-rosa e morta. Os três sons estavam ligados pela luz do dia e pelo ranger das folhinhas da árvore que se esfregavam umas nas outras radiantes.

$[\ldots]$

Houve um momento grande, parado, sem nada dentro. Dilatou os olhos, esperou. Nada veio. Branco. Mas de repente num estremecimento deram corda no dia e tudo recomeçou a funcionar [...]. Só faltava o tin-dlen do relógio que enfeitava tanto. Fechou os olhos, fingiu escutá-lo e ao som da música inexistente e ritmada ergueu-se na ponta dos pés. Deu três passos de dança bem leves, alados (PCS, p. 19-20, Grifo nosso).

Nas palavras que abrem o seu primeiro romance, a autora introduz os sons do mundo moderno na narrativa, fazendo-nos pensar no barulho do mundo como música, aproximando-se das observações de José Miguel Wisnik, em O som e o sentido (2002, p.47), a respeito do "recalque e retorno do ruído", em um capítulo que tem esta expressão como subtítulo e no qual o autor escreveu que "o alastramento do mundo mecânico e artificial cria paisagens sonoras das quais o ruído se torna elemento integrante incontornável, impregnando as texturas musicais". A "orelha à escuta" permanece em toda a narrativa, atenta ao som da chuva, das coisas, das vozes das pessoas, da natureza, dos instrumentos musicais, de tudo, aludindo às sensações 
auditivas da personagem e, ao mesmo tempo, fazendo-nos pensar no ambiente descrito, nas pessoas e mesmo nos acontecimentos da narrativa como fruto do pensamento de Joana, fundamente enraizado no corpo, como o percebeu Regina Pontieri. Joana parece querer captar as coisas como foram sentidos por seu corpo. A narrativa, tratando do espaço ambiente apenas no instante mesmo em que ele é percebido pela personagem, assume uma forma que, por isso mesmo, alude às próprias sensações. $\mathrm{O}$ som já no início do texto põe em questão a percepção do muno pela personagem e, junto com isso, o "mecanismo" da escritura clariciana, que não se detém na reprodução dos fatos como o elemento principal, posto que, no segundo capítulo, a narradora, em terceira pessoa, mas observando os acontecimentos do interior da personagem, arrola os principais acontecimentos da vida de Joana, expondo a consciência de que os fatos são dependentes do olhar que os constituem:

Joana poderia reviver toda a infância... O curto tempo de vida junto ao pai, a mudança para a casa da tia, o professor ensinando-lhe a viver, a puberdade elevando-se misteriosa, o internato... o casamento com Otávio... Mas tudo isso era muito curto, um simples olhar surpreso esgotaria todos esses fatos (PCS, p.31).

O romance começa com Joana-criança percebendo o mundo, criando poesia, brincando:

- Papai, inventei uma poesia.

- Como é o nome?

- Eu e o sol. - Sem esperar muito recitou: - "As galinhas que estão no quintal já comeram duas minhocas mas eu não vi” (PCS, p.20).

Se pensarmos em uma passagem dos diários do pintor Paul Klee (1990, p.452) na qual ele escreveu que "na arte, mais importante do que ver é tornar visível", perceberemos que a poesia de Joana-criança alude ao processo de criação da narrativa que está apenas começando, pois, já neste começo, de modo inocente, ela está ressaltando no visível da poesia o invisível que é matéria da narrativa.

Em outra passagem, Joana-criança se refere ao intervalo que há entre ela e as coisas que deseja tocar: 
Deu um corrupio e parou, espiando sem curiosidade as paredes e o teto que rodavam e se desmanchavam. Andou na ponta dos pés só pisando as tábuas escuras. Fechou os olhos e caminhou, as mãos estendidas, até encontrar um móvel. Entre ela e os objetos havia alguma coisa, mas quando agarrava essa coisa na mão, como a uma mosca, e depois espiava - mesmo tomando cuidado para que nada escapasse - só encontrava a própria mão, rósea e desapontada. Sim, eu sei, o ar! Mas não adiantava, não explicava. Esse era um de seus segredos. Nunca se permitiria contar, mesmo a papai, que não conseguia pegar 'a coisa'. Tudo o que mais valia exatamente ela não podia contar (PCS, p.22).

Gilles Deleuze (2005, p.48), observando que a pintura de Francis Bacon torna o movimento muito intenso e violento, considerou que não é exatamente o movimento que interessa ao pintor, mas a ação de forças invisíveis. Para o crítico, as deformações do corpo na pintura de Bacon resultam dessa causa mais profunda. Uma outra hipótese mais "fenomenológica", porém, está em observar que

Los niveles de sensación verdaderamente serían los dominios sensibles que remitieran a los diferentes órganos de los sentidos; pero, precisamente, cada nivel y cada dominio tendrían una manera de remitir a los otros, independientemente del objeto común representado. Entre un color, un sabor, un tacto, un olor, un ruido, un peso, habría una comunicación existencial que constituiría el momento 'páthico' (no representativo) de la sensación (DELEUZE, 2005, p.48).

Citando exemplos da pintura de Bacon, Deleuze considera que caberia ao pintor "fazer ver" uma espécie de unidade original dos sentidos e fazer aparecer visualmente uma "Figura multisensible". Na pintura, isso será possível se a sensação desse ou daquele domínio for diretamente capturada por uma potência visual que transborde todos os domínios e os atravesse - o ritmo, nas palavras do crítico, "más profundo que la visión, la audición, etc" (p.49).

Sobre o ritmo em Perto do coração selvagem, Regina Pontieri considerou que, na primeira parte do romance, a alternância precisa de duas temporalidades distintas “compõe um movimento ondulatório de alternância regular". Na segunda parte, esse movimento se espaça: 
ao lado de discretas ressurreições da vida anterior ao casamento, há somente o grande refluxo final - viagem, morte, eterno recomeço - marcado pela recorrência dos indícios da infância: o pai, o relógio batendo, galinhas arranhado a terra. Circular e ondulatório, o fim busca o início, Joana 'antes da morte ligar-se-á à infância...' (p192), renascendo através do 'mesmo impulso da maré e da gênese' (p.196) (PONTIERI, 2001, p.88-9).

Percebemos que, na narrativa, os diferentes momentos de vida da personagem não estão organizados em uma seqüência linear com começo, meio e fim. O ritmo circular e ondulatório permite que os diferentes momentos de sua vida sejam apresentados conforme a percepção que tem deles: "círculos de vida" que não valem como experiência, o conhecimento que trazem é "um conhecimento direto, mais como sensação do que percepção" (PCS, p.116). Um desses círculos de vida, o capítulo “...A Tia...", narra a passagem de Joana, após a morte do pai, para a casa da tia, mas a ênfase do capítulo se encontra no instante em que Joana compreende a morte de seu pai, sozinha, entre o céu e a terra, pois, ao sair correndo da casa da tia rumo à praia, a narradora informa que, pela porta aberta, "a tia viu por alguns momentos as pernas magras e descobertas da sobrinha correrem, correrem entre o céu e a terra, até desaparecerem rumo à praia" (PCS, p.47). Para chegar à praia, Joana teve de fazer o movimento de descida:

Lá embaixo o mar brilhava em onda de estanho, deitava-se profundo, grosso, sereno. Vinha denso e revoltado, enroscando-se ao redor de si mesmo. Depois, sobre a areia silenciosa, estirava-se... estirava-se como um corpo vivo. Além das pequenas ondas tinha o mar. O mar - disse baixo, a voz rouca (PCS, p.47).

O mar é descrito como um corpo vivo, ao mesmo tempo sereno e revoltado. E, de fato, há toda uma simbologia do mar relacionando-o à imagem da vida e da morte.

Na praia, Joana, “de cócoras, as pernas trêmulas, bebeu um pouco de mar”. Nesse instante, o mar também a olha: "O mar, além das ondas, olhava de longe, calado, sem chorar, sem seios. Grande, grande. Grande, sorriu ela”. Uma primeira sensação é percebida em seu corpo: 
E, de repente, assim, sem esperar, sentiu uma coisa forte dentro de si mesma, uma coisa engraçada que fazia com que ela tremesse um pouco. Mas não era frio, nem estava triste, era uma coisa grande que vinha do mar, que vinha do gosto de sal na boca, e dela, dela própria. Cada vez que reparava no mar e no brilho quieto do mar, sentia aquele aperto e depois afrouxamento no corpo, na cintura, no peito (PCS, p.48).

O sentimento da personagem não é desvelado, ela mesma não sabia o que sentia: "não sabia mesmo se havia de rir porque nada era propriamente engraçado. Pelo contrário, oh pelo contrário, atrás daquilo estava o que acontecera ontem". A compreensão da morte é um ato perceptivo que se inicia a partir do contato com o mar:

Mas agora era uma alegria séria, sem vontade de rir. Era uma alegria quase de chorar, meu Deus. Devagar veio vindo o pensamento. Sem medo, não cinzento e choroso como viera até agora, mas nu e calado embaixo do sol como a areia branca. Papai morreu. Papai morreu. Respirou vagarosamente. Papai morreu. Agora sabia mesmo que o pai morrera. Agora, junto ao mar onde o brilho era uma chuva de peixe de água. O pai morrera como o mar era fundo! Compreendeu de repente. O pai morrera como não se vê o fundo do mar, sentiu (PCS, p.49).

Saber sobre a morte do pai é um sentimento que brota primeiro como sensação difusa no corpo da personagem e, devagar, transformam-se em pensamento: "Agora sabia mesmo que o pai morrera". Mas ela não o descreve, alude a este sentimento a partir do que sabe do mar: "O pai morrera como o mar era fundo".

Georges Didi-Huberman (1998, p.32), no primeiro capítulo de O que vemos, o que nos olha, observando que "a inelutável modalidade do visível” em Ulisses, de James Joyce, adquire para Stephen Dedalus "a forma de uma coerção ontológica, medusante, em que tudo o que se apresenta a ver é olhado pela perda de sua mãe”, compreende que

cada coisa a ver, por mais exposta, por mais neutra de aparência que seja, torna-se inelutável quando uma perda a suporta - ainda que pelo viés de uma simples associação de idéias, mas constrangedora, ou de um jogo de linguagem -, e desse ponto nos olha, nos concerne, nos persegue (DIDI-HUBERMAN, 1998, p.33). 
Ressaltando que o mar, para Dedalus, torna-se "uma superfície que só é plana para dissimular e ao mesmo tempo indicar a profundeza que a habita, que a move", semelhante ao ventre materno "oferecido à sua imaginação como um 'broquel de velino esticado', carregado de todas as gravidezes e de todas as mortes por vir", DidiHuberman considera que o que indica no mar visível, familiar, exposto à nossa frente esse poder inquietante do fundo é "o jogo rítmico 'que traz a onda' e a 'maré que sobe"”.

$\mathrm{Na}$ narrativa de Clarice Lispector, as sensações são aludidas pelo ritmo da linguagem literária que parece captar o ritmo do movimento do mar para nos fazer ver a espécie de unidade original dos sentidos responsável pela figura multissensível que Deleuze identificou na pintura de Bacon. Relacionada à percepção que Joana tem dos seus círculos de vida, a narrativa nos dá a ver "um conhecimento direto, mais como sensação do que percepção".

Ao final do primeiro capítulo, Joana, quase adormecida, é carregada nos braços do pai: "Era o abraço do pai. O pai medita um instante. Mas ninguém pode fazer alguma coisa pelos outros, ajuda-se. Anda tão solta a criança, tão magrelinha e precoce... Respira apressado, balança a cabeça. Um ovinho, é isso, um ovinho vivo. O que vai ser de Joana?” (PCS, p.24).

No segundo capítulo, a narradora resumiu toda a primeira parte do romance, considerada por Álvaro Lins como a parte "construída em termo de ficção", possivelmente porque, oscilando entre os momentos de Joana-criança e os de Joanaadulta, é possível perceber com mais clareza a separação entre personagem e narradora e, além disso, alguns capítulos que narram momentos de Joana-criança têm estruturação mais episódica. Um bom exemplo disso encontra-se no capítulo “...Um Dia”, que narra dois episódios: a visita de um amigo do pai de Joana e uma cena da menina na escola. Logo no começo do capítulo, a narradora informa que, "na hora do jantar, Joana viu estupefata e contrita uma galinha nua e amarela sobre a mesa”. Em seguida, o pai lhe diz: “- Comprei na esquina” (PCS, p.33). Nenhuma palavra foi trocada entre ambos, no entanto, o pai soube o que Joana pensou ao olhar para a galinha morta sobre a mesa. Galinhas, minhocas, sol e nuvem povoam os poemas desta menina, que, após a morte do pai, vai morar com a tia e escolhe o galinheiro para ser sua casa: "O galinheiro tinha grades e tudo, seria a casa dela" (PCS, p.51). Sobre a conversa mantida pelo pai e o amigo Alfredo, a narradora informa que "falava-se sobre coisas que certamente tinha 
acontecido antes dela nascer. Às vezes mesmo não eram o tipo de coisas que acontecem, só palavras - mas também de antes de ela nascer" e que "Joana preferia mil vezes que estivesse chovendo porque seria muito mais fácil dormir sem medo do escuro" (PCS, p. 34). Ela pede ao pai que fique mais um pouco antes de sair com o amigo, a narradora informa: "pelo menos até que ela tivesse bastante sono para não se deitar sem ouvir chuva, sem ouvir gente, pensando no resto da casa negra, vazia e calada". Atendendo ao pedido, o pai e o amigo permanecem em casa conversando até que a menina durma. Durante a conversa, a imagem que o pai descreve da ex-mulher para o amigo não é fiel a uma imagem verídica, mas sua visão insistia em permanecer:

- Eu tinha má memória, nem me lembrava por que a chamara de bruta. Mas não tão má que a esquecesse. Via-a ainda caminhado sobre um areal, os passos duros, o rosto fechado e longínquo. O mais curioso, Alfredo, é que não poderia ter existido nenhum areal. No entanto a visão era teimosa e resistia às explicações (PCS, p.35).

Joana-criança não dormiu, ouviu a conversa entre o pai e o amigo, e teve medo de Elza, a mãe. Seu último pensamento neste episódio é: “amanhã, amanhã bem cedo ver as galinhas vivas" (PCS, p.37).

$\mathrm{Na}$ primeira parte do romance, as passagens episódicas dizem respeito a cenas presenciadas por Joana no passado e agora narradas em terceira pessoa, mas com um eu narrador subsidiando as reflexões da personagem. Joana-criança sente o barulho da chuva, da casa, das pessoas, como presença, Joana-adulta também. Os sons captados pela grande orelha à escuta preenchem a narrativa nas duas partes da obra.

O capítulo "Alegrias de Joana", ainda da primeira parte, inicia destacando a liberdade de pensamento de Joana: "A liberdade que às vezes sentia não vinha de reflexões nítidas, mas de um estado como feito de percepções por demais orgânicas para serem formuladas em pensamento". O capítulo é preenchido com esses pensamentos confusos dos quais a narradora não sabe nem mesmo se coisas foram pensadas por Joana-criança ou por Joana-adulta, mas a confusão, além de trazer certa graça, para esta narradora, traz a realidade mesma:

As descobertas vinham confusas. Mas daí também nascia certa graça. 
Outras confusões ainda. Assim lembrava-se de Joana-menina diante do mar: a paz vinha dos olhos do boi, a paz que vinha do corpo deitado do mar, do ventre profundo do mar, do gato endurecido sobre a calçada. Tudo é um, tudo é um..., entoara. A confusão estava no entrelaçamento do mar, do gato, do boi com ela mesma. A confusão vinha também de que não sabia se entrara 'tudo é um' ainda pequena, diante do mar, ou depois, relembrando. No entanto a confusão não trazia apenas graça, mas a realidade mesma. Parecia-lhe que se ordenasse e explicasse claramente o que sentira, teria destruído a essência 'tudo é um'. Na confusão, ela era a própria verdade inconscientemente, o que talvez desse mais poder-de-vida do que conhecê-la. A essa verdade que, mesmo revelada, Joana não poderia usar porque não formava o seu caule, mas a raiz, prendendo seu corpo a tudo o que não era mais seu, imponderável, impalpável (PCS, p.55).

Como outros capítulos que tratam dos momentos de sua vida adulta, em "Alegrias de Joana" a simultaneidade de tempo é maior:

Então Joana compreendia subitamente que na sucessão encontrava-se o máximo de beleza, que o movimento explicava a forma - era tão alto e puro gritar: o movimento explica a forma! - e na sucessão também se encontra a dor porque o corpo era mais lento que o movimento de continuidade ininterrupta. A imaginação apreendia e possuía o futuro do presente, enquanto o corpo restava no começo do caminho, vivendo em outro ritmo, cego à experiência do espírito... Através dessas percepções - por meio delas Joana fazia existir alguma coisa - ela se comunicava a uma alegria suficiente em si mesma (PCS, p.53).

Para Regina Pontieri (2001), trata-se do descompasso entre corpo e espírito. Este descompasso se relaciona à configuração do tempo na narrativa. Se entendermos "experiência do espírito" por Joana-adulta criando na imaginação momentos de sua vida; "corpo no começo do caminho" por Joana-criança vivendo o presente que hoje é passado; e "futuro do presente" como uma referência ao que Joana está construindo em pensamento - a narrativa -, podemos pensar no próprio movimento do texto e entender porque o movimento explica a forma. É observando o movimento que se pode ver o presente de Joana-criança vivendo com o corpo as sensações que estão sendo captadas por Joana-adulta em pensamento, mas esta, ao invés de ter-lhe imputado uma ordem que 
atendesse a uma lógica de causa e efeito, permitiu-lhe que atuasse como paisagens sonoras impregnando as texturas musicais que constituem a narrativa.

Em um outro exemplo extraído do mesmo capítulo em questão, pelo mergulho no pensamento da protagonista, a narrativa apresenta diferentes possibilidades do tempo experimentadas simultaneamente:

E Joana também podia pensar e sentir em vários caminhos diversos, simultaneamente. Assim, enquanto Otávio falara, apesar de ouvi-lo, observara pela janela uma velhinha ao sol, encardida, leve e rápida - um galho trêmulo à brisa. Um galho seco onde havia tanta feminilidade, pensara Joana, que a pobre poderia ter um filho se a vida não tivesse secado no seu corpo. Depois, mesmo quando Joana respondia a Otávio, lembrava-se do verso que o pai fizera especialmente para brincar, num dos que-é-que-eu-faço:

Margarida a Violeta conhecia,

Uma era cega, uma bem louca vivia,

A cega sabia o que a doida dizia

E terminou vendo o que ninguém mais via...

como uma roda rodando, rodando, agitando o ar e criando brisa.

Mesmo sofrer era bom porque o mais baixo sofrimento se desenrolava também se existia - como um rio aparte.

E também se podia esperar o instante que vinha... que vinha... e de súbito se precipitava em presente e de repente se dissolvia... e outro que vinha... que vinha... (PCS, p.57-8).

As diversas possibilidades do instante estão presentes não apenas na ênfase da expressão "podia pensar e sentir em vários caminhos diversos, simultaneamente", mas na própria estrutura que o texto assume, pois a narradora passa a identificar-se com a personagem, como observou Nunes (1989), subsidiando a reflexão da mesma. Contribui para entendermos o sentido desta maior simultaneidade de tempo e espaço nas passagens em que a protagonista é adulta, por sinal, maior parte da obra, a observação de que, como escreveu Regina Pontieri (2001, p.90), "o peso maior da obra é o trabalho da personagem enquanto subjetividade rememorante, imaginante, criadora". A forma da narrativa alude às sensações vividas em pensamento, livremente, na imaginação da protagonista. 
Em relação ao tempo na narrativa, observa-se aquilo que Mário Praz denominou de "deslocação da seqüência temporal", destacando-a como equivalente, na ficção, às intersecções de tempo e espaço na pintura moderna. Em relação ao espaço ambiente, podemos dizer que a narrativa registra sensações experimentadas no plano da consciência pela personagem, tal como Francastel observou em relação ao que os pintores modernos realizam em seus quadros. $\mathrm{O}$ espaço onde se insere a personagem não é um espaço dado a priori, sem interferência do corpo que o percebe. Um exemplo pode ser observado na descrição da sala da casa do professor, só percebida pela menina no momento que está fazendo outras descobertas de si mesma:

O que acontecia? Tudo recuava... E de súbito o ambiente destacou-se na sua consciência com um grito, avultou com todos os detalhes submergindo as pessoas numa grande vaga... Seus próprios pés flutuavam. A sala onde já estivera durante tantas tardes refulgia no crescendo de uma orquestra, mudamente, numa vingança pela sua distração. De um momento para o outro Joana descobriu a insuspeita potência daquele aposento quieto (PCS, p.71).

O romance apresenta muitas referências ao trabalho com as palavras, à poesia e à ficção: o pai está escrevendo à máquina; Joana-criança faz poesia; o pai conta ao amigo que ela lhe "disse que quando crescer vai ser herói" (PCS, p.34); Joana fala de si mesma como personagem no diálogo imaginado com a tia:

Veja se compreende a minha heroína, titia, escute. Ela é vaga e audaciosa. Ela não ama, ela não é amada. Você terminaria notando-o como Lídia, outra mulher - uma jovem mulher cheia do próprio destino - observou-o. No entanto o que há dentro de Joana é alguma coisa mais forte que o amor que se dá e o que há dentro dela exige mais do que o amor que se recebe. Compreende, titia? Eu não a chamaria de herói como eu mesma prometera a papai. Pois nela há um medo enorme. Um medo anterior a qualquer julgamento e compreensão (PCS, p192-3).

Outras referências se encontram nas passagens em que Otávio está escrevendo, ele faz menção ao plano para o livro de direito civil, e, ao mostrar a citação de Spinoza para Joana, encontra "uma folha de caderno que intercalava suas páginas. Olhou-a e descobriu a letra incerta de Joana" (PCS, p.140). Além disso, a professora pede aos 
alunos que escrevam o resumo de uma história em que "ele e toda a família dele foram felizes". O professor pergunta a Joana se não vai levar o livro. Joana rouba um livro.

Há passagens em que a narradora, muito próxima à consciência de Joana, reflete sobre a narrativa e, de repente, informa que a personagem, em pensamento, inventava:

Estava alegre nesse dia, bonita também. Um pouco de febre também. Por que esse romantismo: um pouco de febre? Mas a verdade é que tenho mesmo: olhos brilhantes, essa força e essa fraqueza, batidas desordenadas no coração. Quando a brisa leve, a brisa de verão, batia no seu corpo, todo ele estremecia de frio e calor. E então ela pensava muito rapidamente, sem poder parar de inventar (PCS, p. 27-8. Grifo nosso).

Alberto Tassinari (2001, p.69), ressaltando que "no espaço em obra sinais do fazer se mostram muito mais do que os artifícios empregados pelo naturalismo", propondo uma comparação com a língua, observou que "o espectador de um espaço em obra corresponde menos a um falante já familiarizado com a linguagem e mais a um que a aprende", a obra expõe junto com o que comunica passos para compreendê-la. Suas palavras nos reportam à observação de Michel Butor (1974, p.13) de que "o romance tende naturalmente, e deve tender, para sua própria elucidação", embora, como destacou, algumas obras só subsistam pela ilusão mantida acerca de si próprias.

A narrativa de Clarice Lispector ensina-nos a olhá-la em diversos momentos em que dar a ver os sinais do fazer ou alude à forma da narrativa. Quanto aos sinais do fazer, o segundo capítulo é um bom exemplo, pois expõe os pensamentos da personagem como matéria de seu texto: "Pior é que ela poderia riscar tudo o que pensava. Seus pensamentos eram, depois de erguidos, estátuas no jardim e ela passava pelo jardim olhando e seguindo seu caminho [...]. E então ela pensava muito rapidamente, sem poder parar de inventar" (PCS, p.27. Grifo nosso). A alusão à forma se dá em passagens como: "O movimento explica a forma" ou na passagem abaixo, extraída do capítulo "Alegrias de Joana":

Como podia esclarecer a si própria, por exemplo, que linhas agudas e compridas tinham claramente a marca? Eram finas e magras. Em dado momento paravam tão linhas, tão no mesmo estado como no começo. Interrompidas, sempre interrompidas não porque terminasse, mas porque ninguém podia levá-las a um 
fim. Os círculos eram mais perfeitos, menos trágicos, e não a tocavam bastante. Círculo era trabalho de homem, acabado antes da morte, e nem Deus completá-loia melhor. Enquanto linhas retas, finas, soltas - eram como pensamentos (PCS, p. $55)$.

Linhas interrompidas e círculos perfeitos aludem à forma do romance que não é linear. Algumas passagens são como linhas interrompidas que encontram relações com passagens posteriores, outras são como círculos que encerram uma fase da vida da personagem. Como a pintura moderna de superfície indiferenciada, que não subordina o efeito decorativo ao dramático, os acontecimentos narrados no romance não concorrem para um clímax e, nesse sentido, não há hierarquia entre os momentos de vida da personagem.

Para que possamos perceber que o texto nos ensina a olhá-lo, no entanto, devemos observar o que escreveu Merleau-Ponty (2001) sobre deixarmos as palavras e todos os meios de expressão do livro se envolverem em sua disposição singular. Ao fazermos isso, Perto do coração selvagem quase assume a irradiação muda da música, no sentido em que esta arte, como escreveu José Miguel Wisnik,

é capaz de ritmar a repetição e a diferença, o mesmo e o diverso, o contínuo e o descontínuo. Desiguais e pulsantes os sons nos remetem no seu vai-e-vem ao tempo sucessivo e linear mas também a um outro tempo ausente, virtual, espiral, circular ou informe, e em todo caso não cronológico, que sugere um contraponto entre o tempo da consciência e o não-tempo do inconsciente. Mexendo nessas dimensões, a música não refere nem nomeia coisas visíveis, como a linguagem verbal faz, mas aponta com uma força toda sua para o não-verbalizável; atravessa certas redes defensivas que a consciência e a linguagem cristalizada opõem à sua ação e toca em pontos de ligação efetivos do mental e do corporal, do intelectual e do afetivo. Por isso mesmo é capaz de provocar as mais apaixonadas adesões e as mais violentas recusas (WISNIK, 1989, p.28).

O capítulo “...O Banho...”, considerado por Álvaro Lins o momento culminante, embora com a ressalva de que nele a narrativa começa "a desgastar-se de modo irreversível", e por Antonio Candido como o capítulo em que talvez se possa compreender Joana como a personagem central do romance, inicia com a personagem 
roubando um livro. Roubar é um evento que desencadeia a ida de Joana para o internato, mas, antes disso, a narrativa se detém no seu encontro com o professor, quando se revelará que ela não é mais uma menina.

Uma questão que aparece na obra algumas vezes, embora com variações, é "O que vai ser de Joana?". Até o encontro com o professor, esta pergunta foi formulada por terceiros. No final do primeiro capítulo, como uma pergunta meditada pelo pai. No terceiro, feita pelo amigo do pai, e em seguida pela professora na escola. No início do capítulo “...O Banho...”, pela tia, depois que Joana rouba o livro, e, no mesmo capítulo, durante o encontro com o professor, pela própria Joana: “O que vai acontecer comigo?". O professor responde: "Não sei”. Esta resposta, Joana, ao voltar para casa, acredita que seus tios não diriam. A importância da pergunta é ressaltada na narrativa do seguinte modo: “A resposta, sentiu, não importava tanto. O que valia era que a indagação fora aceita, podia existir" (PCS, p.73). Na casa dos tios, a narradora informa que "a doçura da infância desaparecera nos seus últimos traços” (PCS, p.74). Depois, já no internato, durante o banho de banheira, a narradora refere-se à Joana como "a moça". Nesta passagem, o mergulho no interior da personagem é mais demorado. Trata-se de um instante mais lírico, que descreve o modo como Joana se sente na sua puberdade: "Sinto-me espalhada no ar, pensando dentro da criatura, vivendo nas coisas além de mim mesma. Quando me surpreendo ao espelho não me assusto porque me ache feia ou bonita. É que me descubro de outra qualidade" (PCS, p.80). Questionando-se sobre o que deve fazer alguém que não sabe o que fazer de si, Joana conclui: "Nada posso dizer ainda dentro da forma. Tudo o que possuo está muito fundo dentro de mim. Um dia depois de falar enfim, ainda terei do que viver? Ou tudo o que eu falasse estaria aquém e além da vida?". A narrativa ressalta a atualidade do corpo. Joana descobre-se como moça, aproximando-se da Joana-adulta. Difícil saber se é a Joana-adolescente ou a Joana-mulher quem pensa algumas passagens, por exemplo: "Tudo o que foi distanciase de mim, mergulhando surdamente nas minhas águas longínquas. Ouço-a, a queda. Alegre e plana espero por mim mesma, espero que lentamente me eleve e surja verdadeiramente diante de meus olhos" (PCS, p.81). A esse respeito, Antonio Candido tinha notado na existência presente de Joana "uma atualidade bastante estranha", que o impedia de "saber se a narrativa se refere a algo já passado ou em vias de acontecer". Em um momento, Joana-adolescente relembra um pensamento que teve no dia anterior: "Quando ontem, na aula, repentinamente pensei, quase sem antecedentes, quase sem ligação com as coisas: o movimento explica a forma. A clara noção do perfeito, a 
liberdade súbita que senti” (PCS, p.82). A oração "o movimento explica a forma" já tinha aparecido na narrativa como algo pensado por Joana adulta, agora ficamos sabendo quando este lhe ocorreu pela primeira vez: na adolescência, como uma sensação de liberdade súbita. Adulta, recuperou-o acompanhado de um sentimento de súbita compreensão. A essa forma de apresentação do pensamento corresponde a percepção de que nem sempre a sensação (o que o corpo sente) vem acompanhada de uma compreensão (o que o pensamento capta). Desse modo, a narrativa nos permite perceber o descompasso entre corpo e o espírito a partir do instante em que a personagem o experimenta.

Antonio Candido percebeu que, para Clarice Lispector, "a meta é, evidentemente, buscar o sentido da vida, penetrar no mistério que cerca o homem", consciente de que "existe uma certa densidade afetiva e intelectual que não é possível exprimir se não procurarmos quebrar os quadros da rotina e criar imagens novas, novos torneios, associações diferentes das comuns e mais fundamente sentidas". O capítulo “...O Banho..." termina com Joana sentada na Catedral, quando, subitamente "o órgão invisível desabrochou em sons cheios, trêmulos e puros [...]. E era tão perfeito o momento que eu nada temia nem agradecia e não caía na idéia de Deus" (PSC, p.83-4).

No capítulo “A Tia”, destacado por Regina Pontieri (2001, p.107) pela “presença abundante de imagens visuais", Joana, após ter compreendido a morte do pai, permaneceu na praia deitada, de olhos fechados, pensando:

Eu sou uma pessoa. E muitas coisas iam se seguir. $\mathrm{O}$ quê? O que acontecesse contaria a si própria. Mesmo ninguém entenderia: ela pensava uma coisa e depois não sabia contar igual. Sobretudo nisso de pensar tudo era possível. Por exemplo, às vezes tinha uma idéia e surpreendida refletia: por que não pensei isto antes? Não era a mesma coisa que ver subitamente um cortezinho na mesa e dizer: ora, eu não tinha visto! Não era... Uma coisa que se pensava não existia antes de se pensar. Por exemplo, assim: a marca dos dedos de Gustavo. O que se pensava passava a ser pensado. Mais ainda: nem todas as coisas que se pensam passam a existir daí em diante... Porque se eu digo: titia almoça com titio, eu não faço nada viver. Ou mesmo se eu resolvo: vou passear; é bom, passeio... e nada existe. Mas se eu digo, por exemplo: flores em cima do túmulo, pronto eis uma coisa que não existia antes de eu pensar flores em cima do túmulo. A música também. Por que não tocava sozinha todas as músicas que existiam? - Ela olhava o piano aberto - 
as músicas lá estavam contidas... Seus olhos se alargavam, escurecidos, misteriosos. 'Tudo, tudo'. Foi então que começou a mentir (PCS, p.49-50).

A citação exemplifica quando, para Joana, o pensamento dá existência às coisas, quando o pensamento é um ato criativo comparável à música.

A referência à música é recorrente no texto e tem importância para a narrativa, pois está, em diferentes momentos, associada ao pensamento da protagonista que teme pôr em palavras os sentimentos, explicando-se: "porque no momento em que tento falar não só não exprimo o que sinto como o que sinto se transforma lentamente no que eu digo" (PCS, p.29). Joana teme que as palavras aprisionem aquilo que sente confusamente. Mas é no capítulo "Alegrias de Joana”, que se segue ao capítulo "...A Tia...", que entendemos o modo como, para ela, "a música é da categoria do pensamento, ambos vibram no mesmo movimento e espécie. Da mesma qualidade do pensamento tão íntima que ao ouvi-la, este se revela" (PCS, p.54). A aproximação entre música e pensamento, para Joana, está relacionada a sua experiência com a música:

Deixava até de sentir a harmonia quando esta se popularizava - então não era mais sua. Ou mesmo quando a escutava várias vezes, o que destruía a semelhança: porque seu pensamento jamais se repetia, enquanto a música podia se renovar igual a si própria - o pensamento só era igual a música se criando (PCS, p.54).

Ao determo-nos na passagem acima, pensamos na linguagem em sua operação de origem, observada por Merleau-Ponty em relação à linguagem literária, e propomos que há relação entre pensamento, música e literatura no romance clariciano.

Roland de Candé (1994, p.10), após ressaltar que dificilmente a música é definida de forma conveniente, destacou a definição de Abraham Moles como uma das melhores definições propostas em nosso tempo: "uma reunião de sons que deve ser percebida como não sendo o resultado do acaso". Candé considera que a fraqueza desta definição “está em admitir que toda reunião de sons programados e percebidos como tais pode ser qualificada de música... o que talvez seja excessivo (repetição ou permutação automática de alguns sons escolhidos arbitrariamente... linguagem falada...)". Para a protagonista Joana, porém, não é excessivo que o pensamento seja como música escutada pela primeira vez, daí também a ênfase maior ao tempo em detrimento do espaço neste romance, posto que, comparando a música com a arquitetura, Candé nos 
esclareça: "como a arquitetura, a música é um sistema de comunicação não referencial: uma organiza relações temporais, a outra, relações espaciais" (p.15).

Gilles Deleuze (2005, p.64), reportando-se às palavras de Paul Klee sobre a arte não representar o visível, mas tornar visível, observa que a questão da separação das artes perde toda a importância, ao considerar que em arte não se trata de reproduzir ou inventar formas, mas de captar forças, e vê nas figuras de Francis Bacon "una de las respuestas más maravillosas a la pregunta: ¿cómo hacer visibles fuerzas invisibles. Es incluso la función primordial de las Figuras". Ao final do capítulo "Pintar as forças", após apontar as forças invisíveis que Bacon detecta e capta, ressalta: "Hacer el Tiempo sensible en si mismo, tarea común al pintor, al músico, a veces al escritor. Es una tarea fuera de toda medida o cadencia" (p.70).

A narradora, após explicar em que sentido a música era uma categoria do pensamento, dirige-se à visão, observando:

Havia muitas coisas a ver também. Certos instantes de ver valiam como 'flores sobre o túmulo': o que se via passava a existir. No entanto não esperava a visão num milagre nem anunciada pelo anjo Gabriel. Surpreendia-a mesmo no que já enxergara, mas subitamente vendo pela primeira vez, subitamente compreendendo que aquilo vivia sempre. Assim, um cão latindo, recortado contra o céu. Isso era isolado, não precisava de mais nada para se explicar... Uma porta aberta a balançar para lá, para cá, rangendo no silêncio de uma tarde... E de repente, sim, ali estava a coisa verdadeira [...]. Para se ter uma visão, a coisa não precisava ser triste ou alegre ou se manifestar. Bastava existir, de preferência parada e silenciosa, para nela se sentir a marca. Por Deus, a marca da existência... Mas isso não deveria ser buscado uma vez que tudo o que existia forçosamente existia... É que a visão consistia em surpreender o símbolo das coisas nas próprias coisas (PCS, p.54-5).

Nesta passagem, Joana, ao considerar que certos instantes de ver valem como "flores sobre o túmulo", relaciona certos instantes de ver ao pensamento criativo, pois, como foi destacado antes, a frase "flores em cima do túmulo" é um exemplo de uma coisa que não existia antes da personagem pensá-la. Ver e pensar, na poética clariciana, são correlatos do ato criador. Entre os exemplos citados, o de "uma porta aberta a 
balançar para lá, para cá, rangendo no silêncio de uma tarde..." é algo que ela acabou de inventar e do qual ela percebe que "de repente, sim, ali estava a coisa verdadeira".

Regina Pontieri (2001, p.90), observando o imaginário criador de Joana e enfatizando a experiência da oralidade no capítulo “...A Tia...”, considera que o trabalho de imaginação "está fundamente enraizado num corpo com o qual o imaginário se mantém em descompasso. Assim, pode ficar enviesada a trajetória da experiência ao descarnar o vivido, espiritualizando-o". Para Pontieri, do ponto de vista da expressão, o resultado "é algumas vezes um estilo eivado de enigmas e obscuridade". Para nós, Joana, como o pintor de quem Merleau-Ponty diz que oferece seu corpo ao mundo e o transforma em pintura, participa com seu corpo móvel da visão. O vidente, para Merleau-Ponty (2004, p.16), imerso no visível por seu corpo, ele próprio visível, não se apropria do que vê, "apenas se aproxima dele pelo olhar, se abre ao mundo", mas o mundo, por seu turno, não é "em si ou matéria". O movimento do vidente "não é uma decisão do espírito, um fazer absoluto, que decretaria, do fundo do retiro subjetivo, uma mudança de lugar milagrosamente executada na extensão. Ele é a seqüência natural e o amadurecimento de uma visão". Joana não espera a visão anunciada "num milagre nem pelo anjo Gabriel", ela se surpreende mesmo no que já enxergara, subitamente, vendo-o pela primeira, e a narrativa torna visível o momento em que se dá esse instante, criação de um figurativo menos visível a olho nu, daí a necessidade de nós leitores também vermos com nosso corpo o movimento do texto, surpreendendo seus símbolos na linguagem em sua operação de origem.

Pontieri considerou também que, no conjunto do livro,

o tema predominante é o modo como o corpo, como fonte de sensações, serve de matéria ao trabalho de linguagem que caracteriza a aprendizagem de Joana artista. Ou seja, a ênfase vai para o corpo enquanto objeto de assimilação oral, fundamentando a experiência de criação verbal como criação carnal (PONTIERI, 2001, p.107).

Podemos acrescentar que o corpo enquanto objeto de assimilação visual e auditivo também serve de matéria para esta narradora que reconhece a distância que separa os sentimentos das palavras. Nesse sentido, Benedito Nunes (1989, p.123) observou a fascinação contínua que as coisas exercem sobre as personagens de Clarice Lispector, "insinuado-se à experiência interna em momentos de pausa contemplativa, que 
proporcionam independentemente do entendimento verbal, um saber imediato arraigado à percepção em estado bruto".

No final do capítulo “...O Banho...”, há um importante momento de audição em que Joana, sentada na Catedral, ao ouvir o som de um órgão, é invadida pelos sons e sente que "não pensava pensamentos, porém música":

E, subitamente, antes que eu pudesse compreender o que se passava, como um cataclisma, o órgão invisível desabrochou em sons cheios trêmulos e puros. Sem melodia, quase sem música, quase apenas vibração. As paredes compridas e as altas abóbadas da igreja recebiam as notas e devolviam-nas sonoras, nuas e intensas. Elas transpassavam-me, entrecruzavam-se dentro de mim, enchiam meus nervos de estremecimento, meu cérebro de sons. Eu não pensava pensamentos, porém música (PCS, p.83-4).

Dois instrumentos musicais são citados no texto, o piano e o órgão, este último, instrumento preferido do compositor Johann Sebastian Bach, a quem Joana se refere em algumas vezes, especialmente em uma folha de caderno encontrada por Otávio, onde se lê: “A beleza das palavras: natureza abstrata de Deus. É como ouvir Bach” (p.140). Esta frase aproxima palavra e música a partir da admiração da personagem por Bach, compositor cuja importância para a história da música clássica pode ser observada, por exemplo, no estudo de José Miguel Wisnik sobre a música tonal. Wisnik (1989, p.131), ao abordar aspectos importantes do longo processo que engendrou o tonalismos, escreveu:

A síntese desse caminho está na música de Bach: situada barrocamente entre os dois mundos - a polifonia que nela se consuma e finda, e a homofonia, que apontará para os desenvolvimentos futuros do discurso tonal -, a música bachiana parece conter em si a música toda, a condensação do passado e do futuro. A linha progressiva da tonalidade será levada adiante por seus filhos músicos, que, passando ao rococó e ao clássico, consideravam-no, por uma dessas ironias históricas, a 'velha peruca', o cultor de uma linguagem obsoleta. Mas em Bach estão os desenvolvimentos extremos das defasagens polifônicas ao mesmo tempo que os percursos da melodia emancipada, e uma coisa de tal modo entranhada na outra que o pensamento harmônico se realiza plenamente em sua polifonia, assim 
como em peças aparentemente simples e unidimensionais pode se descobrir um cerrado pensamento polifônico (é o caso do primeiro prelúdio do Cravo bem temperado, onde a face tão conhecida esconde em filigrana um surpreendente jogo de defasagens a três vozes) (WISNIK, 1989, p.119).

Sobre Bach, Roland Candé (1994, p.526) ressaltou que enquanto os seus contemporâneos encontravam o sucesso "no lirismo individual, na glorificação do solista", Bach, "o mais ilustre dos grandes músicos", não renunciou ao primado do contraponto, privilegiou a fuga e o coral e entregou "aos coros a parte do leão...". Para Candé, o contraponto e a fuga, que "irão tornar-se entediantes exercícios escolares, cujo rigor criou infelizmente um preconceito desfavorável em relação às formas que o reivindicam”, em Bach "não são coerções", pelo contrário, são "a tal ponto naturais, que lhe acontece acrescentar a posteriori a uma composição partes não previstas (as duas flautas no Esurientes do Magnificat por exemplo") (p.533-4). Considerando que embora o compositor tenha dado "provas de seu gênio melódico, sua fé cristã e sua fidelidade à tradição prenderam-no aos belos cânticos luteranos", mas, sobre as cantadas e Paixões do compositor (Bach produziu três, uma perdida, a Paixão segundo São Marcos) ressaltou: "Traços de união entre a terra e o céu, as melodias populares são a alma das cantatas e das Paixões, e inspiraram as mais belas obras para órgão. É ao coral e à fuga (por vezes unidos) que a obra de Bach deve sua universalidade... e sua serenidade" (p. 538).

Solange Ribeiro de Oliveira (2002, p.127), no capítulo “A melopoética estrutural: contraponto, fuga e rapsódia no texto literário", observando que William Freedman leu o romance Tristram Shandy, de Laurence Sterne, como "uma forma de contraponto literário que antecipa, em quase dois séculos, a 'musicalização da ficção' espetacularmente tentada por Aldous Huxley no 'romance musical' Point Counter Point, de 1928, e reiterada em Themes and Variations, de 1950", escreveu que

Freendam concentra-se em um aspecto da 'musicalidade prismática' do romance: a textura contrapontística, a qual resulta nos efeitos de simultaneidade e de intensa emoção, próprios da arte musical. Sterne simula a simultaneidade dando a impressão de fundir dois pontos de vista, o do narrador adulto e o de sua própria pessoa na qualidade de personagem da história. Mesmo contando episódios de sua infância, o narrador deixa transparecer seu modo de ser maduro em traços 
idiossincráticos da errática narrativa. Nesse sentido, o livro aproxima-se muito da música de J. S. Bach, sempre implicitamente contrapontística, com vozes distintas em uma única linha (OLIVEIRA, 2002, p.127).

Algo semelhante pode ser dito a respeito de Perto do coração selvagem, mas preferimos observar as palavras de Lúcio Cardoso sobre o romance, publicadas no artigo "Perto do coração selvagem”, do dia 12 de março de 1944, no Diário Carioca:

Nesta estranha narrativa, onde o romance se esfuma para se converter muitas vezes numa rica cavalgada de sensações, a poesia brota como uma fonte nova e pura. Não são raros os momentos em que temos a impressão de que a história de Joana vai se deter para transformar num canto, num hino, tal a magia irresistível que envolve o cenário, os sentimentos e as sensações ${ }^{20}$.

No depoimento de Clarice Lispector para o MIS, Marina Colasanti perguntou-lhe se para Perto do coração selvagem ela partiu de uma estrutura de romance já visualizada. A resposta da escritora foi:

Eu tive que descobrir meu método sozinha. Não tinha conhecidos escritores, não tinha nada. Por exemplo, de tarde no trabalho ou na faculdade, me ocorriam idéias e eu dizia: 'Tá bem, amanhã de manhã escrevo'. Sem perceber ainda que, em mim fundo e forma é uma coisa só. Já vem a frase feita. E assim, enquanto eu deixava “para amanhã”, continuava o desespero toda manhã diante do papel em branco. E a idéia? Não tinha mais. Então, eu resolvi tomar nota de tudo o que me ocorria. E contei ao Lúcio Cardoso, que então eu conheci, que eu estava com um montão de notas assim, separadas, para um romance. Ele disse: 'Depois faz sentido, uma está ligada a outra'. Aí eu fiz. Estas folhas "soltas" deram Perto do coração selvagem (OE, p.143).

Benedito Nunes (1996), na "Nota filológica" para a edição crítica de A paixão segundo G.H., reportando à descrição do método da escritora revelado no depoimento para o MIS, considera que seu método, assim descrito, assemelha-se "ao de certas

\footnotetext{
${ }^{20}$ Recorte de jornal sem data, presente no Arquivo Clarice Lispector da Fundação Casa de Rui Barbosa, catalogado como CL16j.
} 
criações musicais que desabrocham em torno de um ou muitos temas, conduzindo a linhas diferentes de variações numa só tonalidade".

Na leitura de Perto do coração selvagem, Nunes (1989, p.21) observou que a inquietude "leva Joana a um constante esforço de expressão artística, a um afã de conhecimento e de criação sempre renovável e deficitário". Entendemos que a analogia com a música, estabelecida pela própria personagem, atende a seu esforço de não aprisionar com as palavras o pensamento. Para entendê-la, devemos observar aquilo que Nunes (1989, p.169) denominou o jogo de identidade da ficcionista consigo mesma e com os seus personagens, ao analisar as obras $A$ paixão segundo G.H., A hora da estrela e Água viva. Para estas narrativas, o crítico considerou que cabe falar em improviso porque, como o impromptu musical, "a escritura se desenrola ao léu de múltiplos temas e motivos recorrentes (autoconhecimento, expressão, existência, liberdade, contemplação, ação, inquietação, morte, desejo de ser, identidade pessoal, Deus, o olhar, o grotesco e/ou escatológico)", mas ressaltou que o improviso é "sobretudo, a improvisação da identidade do narrador fundando-se em confronto com a identidade fictícia de seu personagem". Em Perto do coração selvagem, a identidade da narradora funda-se em confronto com a identidade de Joana, que, por sua vez, enquanto personagem que escreve, confronta-se com a identidade de Otávio e Lídia. A esse respeito, Regina Pontieri (2001, p.105) observou que se pode, em um sentido mais amplo, "ver Joana como uma "arquipersonagem”, já que suas características e sobretudo seu destino condicionam a existência das demais personagens". A isso se pode chamar de tonalidade única do texto.

Já observamos no início da leitura do romance que a poesia de Joana alude ao processo de construção da própria narrativa. $\mathrm{O}$ mesmo pode ser dito em relação às suas brincadeiras. No primeiro capítulo da obra, em uma passagem que narra suas brincadeiras com bonecas, a existência de Joana também condiciona a das demais personagens de sua imaginação:

Já vestira a boneca, já a despira, imaginara-a indo a uma festa onde brilhava entre todas as outras filhas. Um carro azul atravessava o corpo de Arlete, matava-a. Depois vinha a fada e a filha vivia de novo. A filha, a fada, o carro azul não eram senão Joana, do contrário seria pau a brincadeira. Sempre arranjava um jeito de se colocar no papel principal exatamente quando os acontecimentos iluminavam uma ou outra figura. Trabalhava sério, calada, os braços ao longo do corpo. Não 
precisava aproximar-se de Arlete para brincar com ela. De longe mesmo possuía as coisas (PCS, p.21).

No capítulo "A mulher da voz e Joana", a narradora conta que Joana estranhou sua própria voz de recém-casada: "Aquele timbre de recém-casada tinha uma história, uma história frágil que passava despercebida da dona da voz, mas não desta" (PCS, p.85-6). Aqui a narradora destaca que, recém-casada, Joana não percebia o timbre peculiar de sua voz, mas, agora, a narradora, sim. Em seguida, acrescenta: "Desde aquele dia, Joana sentia as vozes, compreendia-as ou não compreendia. Provavelmente no fim da vida, a cada timbre ouvido uma onda de lembranças próprias subiria até sua memória, ela diria: quantas vozes eu tive...” (PCS, p.86). O capítulo narra o encontro de Joana com uma corretora de imóvel e uma história para a vida desta mulher, inventada por Joana a partir de alguns dados e da percepção de sua "voz de terra". Ao final do capítulo, a narradora informa que Joana invejara a mulher da voz e, mais uma vez, a narrativa refere-se à escritura:

Teve um rápido movimento de cabeça, impaciente. Pegou num lápis, num papel, rabiscou em letra intecionalmente firme: 'A personagem que ignora a si mesma realiza-se mais completamente'. Verdade ou mentira? Mas de certo modo vingara-se jogando sobre aquela mulher intumescida de vida seu pensamento frio e inteligente (PCS, p.91).

Um exemplo da coincidência entre pensamento e "música se criando" na imaginação de Joana está no capítulo “Otávio", último da primeira parte. O capítulo começa com "De profundis", espécie de oração, pois a narradora informa que Joana "fechou os olhos, vagarosamente foi descansando. Quando os abriu recebeu um pequeno choque. E durante longos e profundos segundos soube que aquele trecho de vida era uma mistura do que vivera com o que ainda viveria, tudo fundido e eterno" (PCS, p.92). Em seguida observa que "começou a pensar que na verdade rezara. Ela não. Alguma coisa mais do que ela, de que já não tinha consciência rezara”. Imersa em seus pensamentos, a personagem ouvirá o som de um piano: “O piano foi atacado deliberadamente em escalas fortes e uniformes. Exercícios, pensou. Exercícios. Sim, descobriu divertida... Por que não? Por que não tentar amar? Por que não tentar viver?” (PCS, p.96). A partir deste instante a narrativa, que já tinha sido preenchida pela 
história da mulher da voz apenas imaginada por Joana, passa "a entrar por outros destinos", como percebeu Antonio Candido. Supomos que amar e viver, para Joana, relacionam-se ao modo como vai apresentar as personagens Otávio e Lídia, dando-lhes voz, ou seja, como sujeitos e não como objetos de análise da narradora.

A narrativa flui próxima à consciência de Otávio, que sonha música: "Música pura desenvolvendo-se numa terra sem homens, sonhava Otávio" (PCS, p.96). Entra em cena a prima Isabel, que toca piano, depois Otávio se aproxima de Lídia, sua prima e noiva, que está no quarto, e a narrativa passa, agora, a fluir próxima à consciência desta, deixando ver o que ela sente a respeito dele: "Se não o quisesse tanto, como seria difícil suportar toda aquela incompreensão da parte dele. Só se entendiam quando se beijavam, quando Otávio encostava a cabeça assim no seu seio" (PCS, p.101). Durante o diálogo entre os noivos, a narradora mergulha também nos pensamentos de Otávio, permitindonos conhecer o que ele sente por Lídia: "Tinha pena de Lídia, sabia que, mesmo sem motivo, mesmo sem conhecer outra mulher, embora ela fosse a única, ele a abandonaria alguma vez" (PCS, p.103). No final do diálogo entre os dois, há um corte e a narrativa introduz uma nova cena, desta vez, a do primeiro encontro entre Joana e Otávio:

Ela falara do velho, falara da gravidez da cadela mal ele a conhecera e de repente, assustado, ele se sentira como depois de uma confissão, como se tivesse dito àquela estranha toda a sua vida. Que vida? A que se debatia dentro dele e que não era nada, repetiu-se com medo de surgir aos próprios olhos como grandioso e cheio de responsabilidade (PCS, p.109).

Nesta passagem tomamos conhecimento de que Otávio teria contado sua vida para Joana, mas a narrativa não deixa que a onisciência da terceira pessoa prevaleça por muito tempo, logo surge a interrogação “Que vida?” e a resposta dada é próxima a consciência de Otávio.

Sobre "as frases interrogativas, que marcam as hesitações do narrador, dubitativo e perplexo quando coloca um novo elo hipotético, conjetural, na cadeia de suposições que vai formando", Benedito Nunes, atendo-se ao romance $A$ maçã no escuro, escreveu que

pontuam o comentário reflexivo que interioriza a matéria narrativa do texto, valorizando, inclusive, o apelo silencioso das coisas e os momentos inenarráveis. Mas pelo comentário que interpreta a experiência narrada, o sujeito-narrador, 
continuamente presente, também a si mesmo interpreta. A serviço do personagem, a sua voz, que fala dele e por ele, alça-se do espaço comum da narrativa, convertido num espaço agônico, onde se representa o drama da linguagem e da expressão, e que ambos ocupam (NUNES, 1989, p.54).

$\mathrm{Na}$ nova cena, pelo mergulho na consciência de Otávio, conhecemos seus sentimentos em relação à Joana: "Ele a queria não para fazer sua vida com ela, mas para que ela lhe permitisse viver. Viver sobre si mesmo, sobre seu passado, sobre as pequenas vilezas que cometera e a que covardemente continuava unido. Otávio pensava que ao lado de Joana poderia continuar a pecar" (PCS, p.111). A introspecção na consciência das personagens atende ao propósito do capítulo que se intitula "Otávio", mas não trata deste personagem apenas, e sim de aspectos de sua vida que mantêm relação com a vida de Joana. Variando dos pensamentos de Otávio para os pensamentos de Joana, por meio da introspecção, a narrativa nos permite conhecer também os sentimentos dela em relação a ele. Joana parece apaixonada, mas o assunto é tratado, para usarmos termos de Antonio Candido, com "associações diferentes das comuns e mais fundamente sentidas". Como informa a narradora, depois do beijo que recebeu de Otávio, Joana teve dias de "procurar-se muito no espelho, procurando-se sem vaidade". Depois cessou esta felicidade, e então:

a plenitude tornou-se dolorosa e pesada e Joana era uma nuvem prestes a chover. Respirava mal como se dentro dela não houvesse lugar para o ar. Caminhou de um lado para outro, perplexa com a mudança. Como? Perguntava-se e sentia que estava sendo ingênua, aquilo tinha dois lados? Sofrer pelo mesmo motivo que a tornara terrivelmente feliz? (PCS, p.112).

A narradora encerra esta fase da vida de Joana com um simples parágrafo que se resume a "Casou-se". A ênfase maior foi dada aos sentimentos e sensações, e não aos acontecimentos, daí o porquê de a narrativa encerrar passagens tão líricas, que não são meros recursos da poesia aplicados à prosa. A escolha da técnica do monólogo interior, responsável pela apresentação dos personagens como sujeitos, evitou que eles fossem vistos como objetos de análise, pois Joana, quando quis, procurou analisar a vida dos tios, "sabendo que assim os destruiria" (p.74). Os tios são personagens vistos apenas de fora. 
A descrição de como Joana se sente após o casamento segue o lirismo da passagem anterior: "Todo o seu corpo e sua alma perdiam os limites, misturavam-se, fundiam-se num só caos, suave e amorfo, lento e de movimentos vagos como matéria simplesmente viva. Era a renovação perfeita, a criação" (PCS, p.114). Um tempo depois, porém, uma nova sensação: Joana sente que se acomodara numa "confortável felicidade. Não sofria, mas onde estava?” (PCS, p.115). O capítulo, último da primeira parte, encerra mais um círculo na vida desta personagem que está sempre à procura. Há uma longa reflexão sobre sua busca. Os próximos capítulos recuperarão momentos do casamento, do encontro de Joana com a amante do marido, de sua relação com um amante, mas, já aqui, a narradora, a partir de Joana, informa:

Não terei pois uma diretriz. Pensava meses depois de casada. Resvalo de uma verdade a outra, sempre esquecida da primeira, sempre insatisfeita. Sua vida era formada de pequenas vidas completas, de círculos inteiros, fechados, que se isolavam um dos outros. Só que no fim de cada um deles, em vez de Joana morrer e principiar a vida noutro plano, inorgânico ou orgânico inferior, recomeçava-a mesmo no plano humano. Apenas diversas as notas fundamentais. Ou apenas diversas as suplementares, e as básicas eternamente iguais? [...] Era sempre inútil ter sido feliz ou infeliz. E mesmo ter amado. Nenhuma felicidade ou infelicidade tinha sido tão forte que tivesse transformado os elementos de sua matéria, dandolhe um caminho único. Continuo sempre me inaugurando, abrindo e fechando círculos de vida, jogando-os de lado, murchos, cheios de passado [...]. Momentos tão intensos, vermelhos, condensados neles mesmos que não precisavam de passado nem de futuro para existir. Traziam um conhecimento que não servia como experiência - um conhecimento direto mais como sensação do que percepção. A verdade então descoberta era tão verdade que não podia subsistir senão no recipiente, no próprio fato que a provara. Tão verdadeira, tão fatal, que vive apenas em função de sua matriz. Uma vez terminado o momento de vida a verdade correspondente se esgota. Não posso moldá-la, fazê-la inspirar outros instantes iguais. Nada pois me compromete (PCS, p.116. Grifo nosso).

Quando enuncia que "apenas diversas as notas fundamentais. Ou apenas diversas as suplementares, e as básicas eternamente iguais?”, mais uma vez, Joana recorre a uma analogia com a música, se atentarmos para a observação de José Miguel Wisnik (1989, 
p.61), de que "os harmônicos, enquanto formantes de um som, correspondem àquelas vibrações mais rápidas que se incluem, como múltiplos, no mesmo pulso do som fundamental".

Benedito Nunes (1989, p.22) observou que a "dispersão no tempo, através da experiência interior, de uma vida que contém outras, como 'círculos inteiros fechados', é homóloga ao ritmo temporal entrecortado da narrativa". A narrativa alude à sensação da personagem e expõe os sinais do fazer, que neste caso dizem respeito à estrutura da obra.

O final da segunda parte parece um balanço da personagem sobre seus círculos de vida, parece também uma resposta à pergunta "o que acontece depois que se é feliz? O que vem depois?", feita por Joana-criança à professora quando esta pediu aos alunos que escrevessem o resumo de uma história que acabava em final feliz. Em resposta, a professora sugeriu a Joana que guardasse sua própria pergunta e um dia, quem sabe, poderia respondê-la. Para surpresa da professora, a menina não estranhou o pedido. Parece, por fim, relacionar-se à sensação que Joana tivera em outra passagem de que "tudo é um", "apenas diversas as notas fundamentais".

Toda a segunda parte da obra aborda situações entre Joana e outras personagens: Otávio, Lídia e o amante. O amante, talvez um dos personagens mais enigmáticos dos que se relacionam com Joana, é tão estranho para nós leitores quanto o é para Joana.

A insatisfação que aparece depois de um tempo de casada, Joana sente em si mesma, mas pressente em Otávio, odiando-o por isso. A relação entre o casal é aprofundada na segunda parte. Algumas passagens iluminam outras da primeira. No capítulo "O passeio de Joana", da primeira parte, por exemplo, ela interrogou-se: "Como ligar-se a um homem se não permitindo que ele a aprisione? Como impedir que ele desenvolva sobre seu corpo e sua alma suas quatro paredes? E havia um meio de ter as coisas sem que as coisas a possuíssem?” (PCS, p.40). Mais à frente mencionou que Otávio se livrava de sua pergunta com uma frase "fria como cinza, cinza para cobrir o intervalo: está chovendo, estou com fome, o dia está belo" (PCS, p.43). Mas é no capítulo "O casamento", primeiro da segunda parte, que Joana pensa em deixá-lo e se queixa dele não percebê-la: "Esperava que Otávio visse sua atitude, adivinhasse sua atitude de não se mover da cadeira. Ele, no entanto, como sempre, nada adivinhava e justamente nos momentos em que deveria olhar, distraía-se com qualquer coisa" (PCS, p.125. Grifo nosso). 
O próximo capítulo da segunda parte, intitulado "O abrigo no professor", narra um episódio na vida de Joana antes do casamento: a visita que fez ao professor. Ela o encontra abandonado pela esposa e, ao lembrar-se desta, percebe o quanto se identifica com ela: "Joana descobrira surpresa que não só então, mas talvez sempre, se sentira unida a ela, como se ambas tivessem algo secreto e mau em comum” (PCS, p.129). No capítulo "...O Banho...", que narra a visita de Joana durante a puberdade ao professor, na despedida, ela pensou: "A mulher - ou era engano? - a mulher olhou-a bem nos olhos, entendendo, entendendo". Se pensarmos no triângulo professor, esposa e Joana, a ligação entre ambas se dá em função do sentimento pelo professor, mas se pensarmos também no triangulo Otávio, Joana e Lídia, Joana, esposa, ocupa agora a mesma posição da mulher do professor que o abandonou. Não é o sentimento que une Joana à ex-mulher do professor, mas "algo secreto e mau", pois o sentimento de Lídia por Otávio não faz Joana sentir-se unida a esta mulher, pelo contrário, no capítulo "Lídia", Joana se dá conta de sua diferença em relação à amante de seu marido: "De tarde pôde enfim observar Lídia e soube que estava tão longe dela como da mulher da voz" (PCS, p.158). Lídia, a amante, se entrega inteiramente aos sentimentos por Otávio, desejando, no fundo de tudo, a "pequena família", expressão que dá título a um outro capítulo. Joana, diferentemente, incomoda-se por se sentir presa ao sentimento por Otávio:

Antes dele, estava sempre de mãos estendidas e quanto oh quanto não recebia de surpresa! De violenta surpresa, como um raio de doce surpresa, como uma chuva de pequenas luzes... Agora tinha todo o seu tempo entregue a ele e os minutos que eram seus ela os sentia concedidos, partidos em pequenos cubos de gelo que devia engolir rapidamente, antes que derretessem. E fustigando-se para andar a galope: olhe, que esse tempo é liberdade! olhe, pense depressa, olhe, encontre-se depressa, olhe... acabou! Agora - só mais tarde, de novo a bandeja de cubinhos de gelo e você diante dela fascinada, vendo os pingos d'água já escorrerem (PCS, p.123).

A imagem dos cubos de gelo derretendo enquanto a personagem não decide engoli-los alude aos minutos que são dela, mas ela os sente passar com o pensamento fixo em Otávio. A narradora informa que quando ele vinha, "ela repousava enfim, com um suspiro, pesadamente. Mas não queria repousar! - $\mathrm{O}$ sangue corria-lhe mais vagarosamente, o ritmo domesticado, como um bicho que adestrou suas passadas para 
caber dentro da jaula". Por esta imagem, a sensação de estar presa parece ainda mais forte.

No capítulo "Lídia", Joana vai ao encontro da amante do marido, após receber o bilhete convidando-a. É quando pode observá-la e descrevê-la: “Que mulher bela. Os lábios cheios mas pacíficos, sem estremecimentos, como de alguém que não tem receio do prazer, que o recebe sem remorsos" (PCS, p.158). Esta passagem nos remete ao diálogo que Joana, na puberdade, manteve com o professor. Ele lhe ensinara que na busca de prazer

está resumida a vida animal. A vida humana é mais complexa: resume-se na busca do prazer, no seu temor, e sobretudo na insatisfação dos intervalos. É um pouco simplista o que estou falando, mas não importa por enquanto. Compreende? Toda ânsia é busca de prazer. Todo remorso, piedade, bondade, é o seu temor. Todo o desespero e as buscas de outros caminhos são a insatisfação. Eis aí um resumo, se você quiser. Compreende? (p.62-3).

Joana respondeu que "sim". A complexidade da vida humana assim resumida está presente na busca de prazer, nos medos e insatisfações das personagens do romance, condicionadas pela existência de Joana.

Na passagem da infância para a adolescência, o professor perguntara a Joana: “Qual é a coisa que você mais gosta?". A reposta foi: “É como uma vontade de respirar muito, mas também o medo... Não sei... Não sei, quase dói. É tudo... é tudo" (p.64). Joana-adulta, pensando sobre seus desejos, reconhece: "Desejava ainda mais: renascer sempre, cortar tudo o que aprendera, o que vira, e inaugurar-se num terreno novo onde todo pequeno ato tivesse significado, onde o ar fosse respirado como da primeira vez" (p.94). Podemos falar em um desejo de inocência, mais tarde, explicitamente, relacionado à atividade do artista no texto da escritora intitulado "O artista perfeito", publicado em 1969, no Jornal do Brasil, ao ressaltar que "arte, imagino, não é inocência, é tornar-se inocente".

Benedito Nunes (1989, p.24) considera como um dos aspectos fundamentais deste romance o caráter inacabado da narrativa. Sobre o último capítulo da obra observa que renasce "a inquietação da liberdade e a promessa de uma vida plena". Para o crítico, "continua, pois, nessa viagem, que deixa a narrativa suspensa à possibilidade de uma 
busca que recomeça, a errância da personagem. $\mathrm{O}$ inacabamento da narrativa reduplica a existência inacabada da protagonista".

Joana é uma protagonista que tem olhos e ouvidos atentos, é alguém para quem cada momento feliz e infeliz da vida tem importância, desde que nele se sinta que se vive, mas não serve como experiência. Perto do selvagem coração parece ser esse estado, a busca dele, a luta para alcançá-lo constantemente, afinal, dissera Joana ao professor no capítulo “...O Banho...”: “ - Mau é não viver”, e sem deixar que ele se confundisse ao indagá-la se isso significava morrer, respondeu: “- Mau é não viver, só isso. Morrer já é outra coisa. Morrer é diferente do bom e do mau" (PCS, p.63-4). Mas há um esforço de Joana que é ainda maior: o de contar, pensar, imaginar essa procura, torná-la visível, sem que as palavras aprisionem os sentimentos.

A narrativa termina com Joana apontando para um novo começo: "De qualquer luta ou descanso me levantarei forte e bela como um cavalo novo". Se pensarmos, junto com Pontieri, que a aprendizagem de Joana é a aprendizagem do artista, vale observar que esta aprendizagem é algo que não termina, começa a cada novo trabalho.

O título da obra, Perto do coração selvagem, foi extraído da seguinte passagem de Portrait of the artist, de James Joyce: "Ele estava só. Estava abandonado, feliz, perto do coração selvagem da vida”. Na carta de 21 de março, de 1944, para Lúcio Cardoso ${ }^{21}$, Clarice Lispector recorda que o título foi uma sugestão do amigo: "Você se lembra que eu dei o livro datilografado (já pela terceira vez) para você e disse que estava lendo o Portrait of the artist e que encontrara uma frase bonita? Foi você quem me sugeriu o título". A passagem citada de Portrait of the artist compõe a epígrafe do romance clariciano. $\mathrm{O}$ título alude a um estado que não é representativo, a narrativa, no entanto, por meio do ritmo de procura, permite-nos percebê-lo em diferentes momentos de vida da protagonista.

Paul Klee (1990, p265), em outra passagem dos Diários, escreveu que "uma obra de arte consegue transcender o naturalismo quando a linha - como ocorre nos desenhos e quadros de Van Gogh e na arte gráfica de Ensor - aparece como elemento pictórico autônomo". É o que ele faz em própria pintura, e o que Clarice Lispector fez por meio da palavra em seu romance. Quem for direto à procura da representação em Perto do

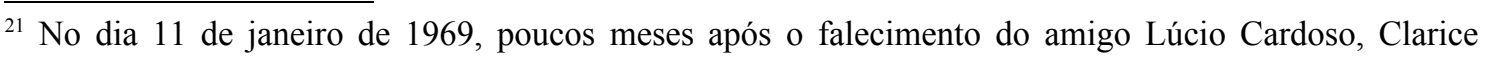
Lispector publicou, no Jornal do Brasil, um texto homônimo do nome do escritor, no qual declara seu apreço pelo amigo, que não podia ouvir nem mesmo se ela "gritasse que ele fora a pessoa mais importante" de sua vida durante a sua adolescênia: "Naquela época ele me ensinava como se conhecem as pessoas atrás das máscaras, ensinava o melhor modo de olhar a lua. Foi Lúcio que me transformou em 'mineira': ganhei diploma e conheço os maneirismos que amo nos mineiros" (DM, p.167).
} 
coração selvagem não terá lido a obra, não terá visto e ouvido a figura multissensível que é o texto.

\section{Laços de família (1960)}

Vivendo em Nápoles desde 1944, mas com mudança prevista para Berna, Clarice Lispector voltou ao Brasil em 1946 para o lançamento do seu segundo romance, $O$ Lustre $^{22}$, pela editora Agir. Posteriormente, em Berna, escreveu o romance $A$ cidade sitiada, que foi publicado no Brasil em 1949 pela editora $A$ Noite, a mesma que publicou Perto do coração selvagem.

Entre as transformações ocorridas no Brasil no início dos anos 1950, Teresa Montero Ferreira (1999) destacou: a televisão brasileira inaugurada em São Paulo, o retorno de Getúlio Vargas à presidência, a era das grandes reportagens e a I Bienal de São Paulo. Nesta Bienal, Max Bill, importante artista concreto suíço, como informou Ferreira Gullar (1999, p.215), levou "o grande prêmio de escultura com sua Unidade tripartida. A partir de então, no Rio e em São Paulo, os artistas jovens entregaram-se de maneira mais decidida às experiências no campo da linguagem geométrica".

Otília Arantes (2004, p.15), escrevendo sobre o itinerário crítico de Mário Pedrosa, observou que, em 1945, “embora tivéssemos passado por uma revolução modernista e produzido grande pintura", a arte brasileira "continuava muito presa à figuração dos anos 1920, às lições do cubismo e do expressionismo e a uma temática de forte cunho nacionalista". Nos anos 1950, "os museus de arte moderna de São Paulo e Rio, juntamente com as bienais, começavam a habituar o gosto do público às tendências internacionais mais recentes", mas a questão da arte abstrata ainda permanecia tabu. A passagem abaixo é um exemplo de como este tabu era tratado:

Assim, em 1952, em pleno auditório do Ministério da Educação, num debate sobre o dilema, para muitos cívico-nacional - 'arte abstrata ou arte com temática social' -, Mário Pedrosa pôs em pé de guerra a platéia ao defender, junto com Flávio de Aquino, e polemizando com Mário Barata e Campofiorito, a causa da abstração, ou da arte concreta, como a chamava desde os artigos sobre Calder. Inutilmente procurou mostrar aos presentes que a nova arte estava elaborando

\footnotetext{
${ }^{22}$ Em uma das correspondências de Clarice Lispector para Lúcio Cardoso, sem data, a escritora informa que o romance $O$ Lustre está terminado, mas que tinha a impressão de que o mesmo já estava terminado antes de sair do Brasil.
} 
símbolos de uma linguagem plástica inédita, destinada a nos arrancar da atonia perceptiva cotidiana, na esperança de encurtar a distância que nos separa dos 'horizontes longínquos da utopia' (ARANTES, 2004, p.17).

Um ano depois, como informa Arantes, ocorria no hotel Quintandinha a primeira Exposição Nacional de Arte Abstrata, "que logo será a tendência dominante no Brasil" (p.18).

Ao voltar ao país em 1951, antes de mudar-se para Washington, Clarice Lispector recebeu o convite para colaborar no jornal $O$ comício, fundado por Joel Silveira, Rubem Braga e Rafael Correa de Oliveira. De acordo com a biográfa Teresa Cristina, também foram convidados Fernando Sabino, Otto Lara Resende, Millôr Fernandes, Paulo Mendes Campos, Sérgio Porto, Carlos Castello Branco, Antônio Maria, Lúcio Rangel, Tiago de Mello e Hélio Pellegrino. Adotando o pseudônimo de Teresa Quadros, Clarice escrevia uma página feminina, destinada, em sua maioria, a leitoras que, como analisa Ferreira,

ainda estavam presas aos limites impostos pela moral dos anos 40: casar, sobretudo, virgem. E jamais incluir em seu vocabulário a palavra divórcio; mulher desquitada era mal vista. Mas, diante das mudanças, ainda que lentas, nos padrões de comportamento da mulher, Clarice mostrava-se atenta e revelava uma compreensão da questão da emancipação feminina condizente com o pensamento em voga, principalmente depois da publicação na França, em 1949, de $O$ segundo sexo, de Simone de Beauvoir (FERREIRA, 1999, p.175).

Em 1952, ano em que colaborava para $O$ comício, publicou seu primeiro volume de contos e passou a residir em Washington. Este primeiro volume de contos, intitulado Alguns contos, foi publicado pelo Ministério da Educação e Saúde. De acordo com Teresa Montero Ferreira, a primeira impressão do volume de contos da escritora intitulava-se Mistério em São Cristóvão, mas trazia o nome Clarice grafado com "ss". Foi recolhida e "finalmente saiu a definitiva, intitulada Alguns contos" (p.177). Pertencem a esta reunião os contos "Amor", "Começos de uma fortuna", "Uma galinha", "Mistério em São Cristóvão", "O jantar" e "Os laços de família”.

Em 1954, Clarice visitou o Brasil de férias e Simeão Leal encomendou-lhe mais alguns contos sob pagamento antecipado. Teresa Montero Ferreira informa que "por 
isso, ela interrompeu o romance que estava escrevendo todas as manhãs com muito prazer e dedicou-se totalmente à feitura dos contos" (p.186). O romance era $A$ maçã no escuro.

Com relação ao momento da elaboração dos contos, Nádia Battella Gotlib (1995, p.300), após leitura das correspondências trocadas entre Clarice Lispector e Fernando Sabino, de 1954 até 1955, observou que "fica patente que, já na década de 50, muitos contos que serão publicados nos anos 60 e 70 já existiam". No depoimento de Clarice Lispector na sede do MIS, a escritora, informando que "já tinha escrito contos antes" de Perto do coração selvagem, ressaltou: Laços de família e $A$ maçã no escuro foram escritos ao mesmo tempo. Eu ia para um conto, escrevia e voltava para $A$ maçã no escuro" (OE, p.150).

Nas cartas trocadas entre Clarice Lispector e Fernando Sabino ${ }^{23}$ é possível acompanhar uma parte da história da publicação dos contos de Laços de família. Na carta de 30 de março de 1955, remetida à escritora, Fernando Sabino comenta que a irmã de Clarice, Tânia, incumbiu-lhe de entregar os contos a Simeão Leal, mas, a ênfase maior de suas palavras está no entusiasmo pelos contos que lhe agradaram muito. Oito títulos são citados: "A imitação da rosa", "A mensagem”, “A criança e o professor", "Os devaneios da galeguinha", "Feliz aniversário", "O crime do professor de matemática", "A menina ruiva" e "Os obedientes". Ao final da carta, Sabino sugere a reunião destes contos aos anteriores para compor um só livro:

E no mais, só sinto que você não tenha pensado em reuni-los todos, os outros alguns também, para fazer um livro só - que seria exata, sincera, indiscutível e humildemente o melhor livro de contos já publicado no Brasil. É o que Simeão pretende fazer - ele me disse. Mas um livro mesmo - e não nos Cadernos de Cultura (SABINO, Apud JACINTHO, 1997, p.479).

Porém, em correspondência de janeiro de 1957, Sabino sugere à Clarice que publique os contos separadamente. Ele os apanharia com o Simeão e mandaria cópia para o Décio de Almeida Prado, que incluiu o nome da escritora entre os colaboradores do Suplemento Literário d'O Estado de São Paulo.

\footnotetext{
${ }^{23}$ Consultamos a dissertação de Valéria Franco Jacintho, Cartas a Clarice Lispector - correspondência passiva da escritora, depositada na Fundação Casa de Rui Barbosa, e os volumes Cartas perto do coração - Fernando Sabino e Clarice Lispector e Correspondências - Clarice Lispector.
} 
Quase quatro anos depois, na correspondência de 16 de fevereiro de 1959, Sabino comenta que as provas dos contos devem ter sido enviadas à escritora por Simeão Leal.

Em 10 de março de 1959, Clarice endereça de Washington uma carta a Simeão Leal reiterando a proposta de desfazer o acordo, propondo a devolução do adiantamento recebido, a fim de publicar os contos em jornais e revistas. Comentado a impossibilidade de publicá-los separadamente na atual circunstância, declara: "Só uma vez resolvi - diante da coisa cada vez mais vaga que se tornara a publicação do livro assumir compromisso. Aceitei uma proposta de $O$ Estado de São Paulo. Acontece que eles só chegaram a publicar um conto". ${ }^{24}$

Teresa Montero Ferreira (1999, p.202) escreveu que, nesse período, Clarice negociava com a revista Senhor, aguardava a resposta de Simeão para dispor de seus contos e "fazia um contato com a editora Agir na esperança de que eles se interessassem em publicar seu livro de contos Laços de família. Dos 15 contos entregues a Simeão Leal (com 176 páginas nas provas), ela acrescentou mais três". O acordo com a editora Agir não deu certo.

De acordo com Nádia Gotlib (1995), em março de 1959, Clarice publicou no número 1 da revista Senhor o conto "A menor mulher do mundo"; em junho, "O crime do professor de matemática", em outubro, "Feliz aniversário", e em dezembro, "Uma galinha”. Neste mesmo ano, voltou a morar definitivamente no Rio de Janeiro, após a separação conjugal. No Brasil, ainda colaborando para a revista Senhor, com o pseudônimo de Helen Palmer ${ }^{25}$, passou a escrever a seção feminina do jornal o Correio da manhã. Posteriormente, trabalhou no Diário da noite, de abril de 1960 a março de 1961, assinando, como Ilka Soares, a coluna intitulada "Só para mulheres".

Quanto à publicação do segundo volume de contos, Teresa Montero Ferreira observou que, após anos de espera, a escritora

conseguiu assinar um contrato com a Francisco Alves, no dia 5 de julho de 1960, para publicar Laços de família. Com uma tiragem de dois mil exemplares, foram publicados 13 contos, dos quais seis já haviam sido incluídos no volume Alguns contos, de 1952, publicado pelo serviço de Documentação do Ministério de Educação e Saúde. Os restantes, com exceção de Devaneio e embriaguez duma

\footnotetext{
${ }^{24}$ Conforme esclarece Jacintho (1997, p.357), o conto em questão é "Preciosidade", também publicado no volume Laços de Família (1960).

${ }^{25}$ De acordo com Gotlib (1995, p.330), a coluna Correio feminino - Feira de utilidades era editada às quartas e sextas, no segundo caderno do jornal, de agosto de 1959 a fevereiro de 1961.
} 
rapariga e Preciosidade, tinham sido publicados na revista Senhor: A imitação da rosa, Feliz Aniversário, A menor mulher do mundo, O crime do professor de matemática e $O$ búfalo. A Senhor foi a grande responsável pela repercussão desses contos, a ponto de despertar o interesse das editoras para publicar Clarice Lispector no Brasil oito anos após o lançamento de Alguns contos. No dia 27 de julho, Laços de família foi lançado na sede da editora Francisco Alves, em São Paulo, na rua Líbero Badaró, 292 (FERREIRA, 1999, p. 211).

Os jornais que noticiaram o lançamento do livro informavam também sobre a realização da exposição de Cyro del Nero, autor da capa e das ilustrações da obra, ocorrida simultaneamente. Por exemplo, o Primeiro Caderno do jornal Folha de São Paulo, no dia 28 de julho de 1960, trazia a seguinte notícia:

Num coquetel na Livraria Francisco Alves, na tarde de ontem, foi lançado o livro "Laços de família" da escritora Clarisse [sic] Lispector. Na mesma ocasião foi inaugurada uma exposição de trabalhos de Cyro del Nero, autor da capa e ilustrações do livro. O coquetel de lançamento foi promovido pela editora Laços de família [sic] e pela revista Senhor. Na foto a escritora Clarisse Lispector autografa exemplares de seu livro.

O Diário de São Paulo do dia 31 de julho de 1960, ao noticiar o lançamento de Laços de família, elogiava o trabalho de "capa e ilustração magníficas assinadas por Cyro del Nero" 26.

A primeira edição de Laços de família, publicado pela editora Francisco Alves, logo após a primeira página de cada conto, apresentava uma ilustração de Cyro del Nero $^{27}$. No dia 13 de abril de 2007, encontramo-nos para uma conversa a respeito dessas ilustrações. Este momento, além de agradável, foi sobretudo esclarecedor sobre o processo de criação empregado para as ilustrações de Laços de família (apreciadas e discutidas pela escritora e pelo ilustrador antes da publicação do livro) e sobre o modo como Cyro del Nero entende o trabalho de ilustração na obra literária. Posteriormente,

\footnotetext{
${ }^{26}$ Ver os recortes de jornais pertencentes ao Arquivo Clarice Lispector da Fundação Casa de Rui Barbosa. Anexos 1 e 2.

${ }^{27} \mathrm{Na}$ época, Cyro del Nero era um jovem em início de carreira. Hoje, é doutor em Artes Cênicas pela Universidade de São Paulo e professor titular da mesma, com atividades artísticas nas áreas de cenografia, teatro, artes gráficas, ópera e televisão.
} 
atendendo a um pedido nosso, recebemos do artista o texto abaixo que, em poucas palavras, retoma o que nos disse pessoalmente:

Creio que todos os que se aproximaram fisicamente de Clarice Lispector puderam ter a experiência de um encontro marcante. Isto não pela exigência intelectual da mesma, mas pelo pathos individual que a cercava.

Meu contato foi ao redor do que deveriam ser as ilustrações para seu Laços de Família e A Maçã no Escuro.

Recebi o convite de Clarice para ir ao Rio de Janeiro (seu apartamento no Leme) e lá discutimos as ilustrações de Laços de Família e a solicitação que ela me fez foi a de não estar com a idéia das imagens tão rentes ao texto, que elas não interviessem no segredo dos mesmos.

Foi uma longa discussão a respeito do que deveria ser uma ilustração.

Como conseqüência do nosso encontro, duas ou três ilustrações foram alteradas.

O processo que usei nas ilustrações que criei na época foi o de encontrar um relevo pictórico e não gráfico. E o fiz quase em três dimensões usando para isso tinta branca grossa e depois uma pátina preta. A idéia era inscrever um realce vigoroso em prosa tão vigorosa, tão segura de si era a autora.

Hoje revejo as ilustrações dessas primeiras edições e sinto que o tempo passou como um vento nas atuais ilustrações de obras literárias e em lugar de deixar uma contribuição, esvaziam-nas.

Meu intuito original era gravar para sempre, criar o primeiro gesto do homem que era imprimir um relevo na pedra com a mancha da própria mão.

Consulto sempre as ilustrações atuais das reedições dos muitos livros que ilustrei e sinto que a perspectiva dos seus desenhistas se tornou muito mais decorativa e menos uma visão pessoal e íntima das obras.

Clarice Lispector foi a leitura e a forte comoção a qual emprestei uma opinião. Uma visão comovida ${ }^{28}$.

\footnotetext{
${ }^{28}$ Correspondência pessoal. Entre os livros ilustrados por Cyro del Nero, tivemos acesso aos seguintes: SEFÉRIS, Giorgos, Poemas. Seleção, introdução e tradução de José Paulo Paes. São Paulo: Nova Alexandria, 1995 (Capa de Cyro del Nero); SIQUEIRA, José Rubens. Viver de teatro. Uma biografia de Flávio Rangel. São Paulo: Nova Alexandria, 1995. (Capa e projeto gráfico de Cyro del Nero); REGO, José Lins do. Água-Mãe, Fogo morto. Rio de Janeiro: José Olympio, 1961. Coleção romances reunidos e ilustrados de José Lins do Rego (Capa de Cyro del Nero); JESUS, Carolina Maria de. Quarto de despejo. Diário de uma favelada. Rio de Janeiro: Francisco Alves, 1960 (Capa de Cyro del Nero).
} 
A única edição de Laços de Família ilustrada, de nosso conhecimento, foi a primeira, editada pela Francisco Alves.

O intervalo entre o último romance publicado e Laços de família é de quase dez anos. Esta obra, de certo modo, marcava o retorno de Clarice Lispector ao ambiente literário brasileiro, prova disso é o fato de que foi bem recebida pelos críticos e bem noticiada em diversos jornais de grande circulação. Além disso, em 1976, durante depoimento ao MIS, a escritora informou que já se encontrava na sétima edição.

Em 1961, Clarice Lispector publicou, também pela editora Francisco Alves e com capa de Cyro del Nero, o romance $A$ maçã no escuro, que recebeu o prêmio Carmem Dolores Barbosa de melhor livro do ano.

\section{"O jantar"}

Em 1946, como informa Nádia Gotlib (1995), Clarice Lispector esteve no Brasil e sua visita ao país foi noticiada no jornal $A$ manhã, do Rio de Janeiro, de 13 de fevereiro. No mês de outubro do mesmo ano, o jornal A manhã publicou o conto "O jantar", de Clarice Lispector, com a ilustração de Santa Rosa conforme reprodução abaixo:

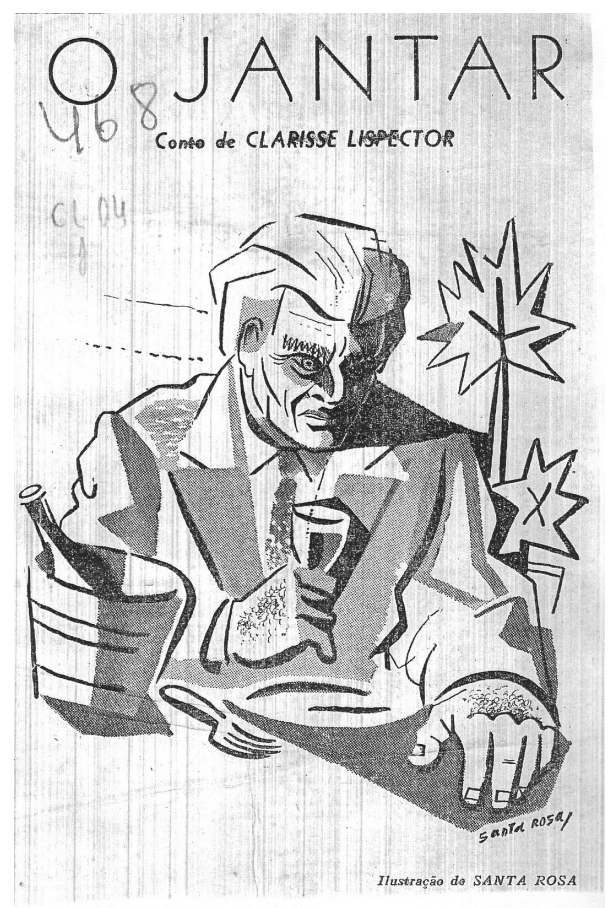


No final do conto publicado no jornal, encontrava-se a seguinte indicação: "Berne (Suíça), setembro de 1946"29.

Um narrador de primeira pessoa, bem posicionado em relação ao ambiente que o cerca, dedica-se a olhar um homem recém-chegado. É a partir daí que a narrativa se inicia: "Ele entrou tarde no restaurante. Certamente ocupara-se até agora em grandes negócios. Poderia ter uns sessenta anos, era alto, corpulento, de cabelos brancos, sobrancelhas espessas e mãos potentes. Num dedo o anel de sua força. Sentou-se amplo e sólido" (LF, 91). O narrador parece fotografá-lo. O conto termina quando o "velho" (é assim que o narrador se refere à personagem) deixa o restaurante.

Affonso Romano de Sant'Anna (1974, p.189) observou que o conto, embora narrado em primeira pessoa, "assume tom idêntico da narração em terceira do singular desde que o personagem-narrador elege o 'outro' como objeto de sua narração". Observamos que o narrador adota a primeira pessoa para falar do outro ao alcance de sua visão, mas não toca no passado nem do futuro da personagem, nem realiza o mergulho no interior da mesma. Ao informar que o homem "poderia ter uns sessenta anos", parece não conhecê-lo. O conto não é a narrativa sobre o velho homem, mas a narrativa do movimento deste narrador que está olhando e tornando visível um outro que, de algum modo, interessa-lhe.

Para Fábio Lucas (1983, p.142), o ponto extremo da náusea pode ser buscado neste conto, "narrado em primeira pessoa masculina, em que o narrador observa, repugnado e com angústia, a refeição de um velho num restaurante". No plano do enunciado é isso o que acontece, mas no plano da enunciação há muito mais coisa do que a narrativa do nojo pelo modo como um homem velho come à mesa de um restaurante.

Buscando uma classificação para este conto, poderíamos repetir as palavras de Fábio Lucas e dizer que estamos diante de um "conto de atmosfera", pois este é

mais adequado ao "herói de consciência" do que à personagem de ação. A situação dramática requer, quase sempre, ambientes íntimos, espaços circunscritos - uma alcova, um terraço, um restaurante, um vagão de trem, por exemplo dentro dos quais se pode penetrar na intimidade psicológica da personagem (LUCAS, 1983, p.111).

\footnotetext{
${ }^{29}$ Ver no Arquivo Clarice Lispector da Fundação Casa de Rui Barbosa a pasta referente a recortes de autoria de CL: CL/j 04.
} 
No entanto, o tom confidencial que o narrador parece assumir apenas simula construir uma narrativa semelhante à do conto de atmosfera descrito acima. $\mathrm{O}$ narrador não cria uma intimidade psicológica para a personagem. $\mathrm{O}$ uso constante de advérbios de dúvida pelo narrador evidencia que suas observações nem sempre são seguras, algumas são suposições sobre o outro. A descrição do velho alimentando-se à mesa é repugnante, e é capaz de fazer o leitor não ver além desta situação, deixando de notar que o narrador participa ativamente da narrativa e, embora tente manter a objetividade da terceira pessoa, em alguns instantes, sucumbe à subjetividade da primeira. Por exemplo, no momento em que descreve a voz do velho: "A voz que esperava dele: voz sem réplicas possíveis pela qual eu via que jamais se poderia fazer alguma coisa por ele" (LF, p.92). Nota-se que o verbo "ver" usado em relação à voz do outro homem indica apenas que o narrador "intuía".

O tempo verbal é variado. Ora observa-se o pretérito perfeito do indicativo, encerrando uma ação concluída ("Ele entrou tarde do restaurante"); ora o pretérito mais-que-perfeito, como tentativa de sugerir um fazer para o velho homem antes de chegar ao restaurante (“Certamente ocupara-se até agora em grandes negócios”); ora o presente do indicativo, assegurando que narrador e velho homem partilham o mesmo instante ("mastiga devagar o resto de comida ainda na boca"); ora o futuro do presente pelo uso do presente com valor de futuro, antecipando o que o velho homem fará logo em seguida ("Daqui a um segundo, porém, está refeito"). Mas o tempo que prevalece é o presente imediato, o instante de agora. $\mathrm{O}$ narrador não se fixa no antes nem do depois do momento em que a personagem chega ao restaurante. Ele se fixa no agora.

$\mathrm{Na}$ pintura de Francis Bacon, Gilles Deleuze observou que os diferentes procedimentos usados pelo pintor para delimitar o lugar onde está a figura (a personagem) - pô-la em uma pista, em um cubo, num trilho, etc - são procedimentos que

deben hacer sensible una especie de marcha, de exploración de la Figura por el lugar, o de si misma. Es um campo operatorio. La relación de la Figura con su lugar aislante define un hecho: el hecho es... eso que tiene lugar... Y la Figura de este modo aislada se convierte en una Image, en un Icono (DELEUZE, 2005, p. 14). 
Perguntando-se sobre o porquê disso, Deleuze responde com palavras do próprio pintor: "para conjurar el carácter figurativo, ilustrativo, narrativo, que la Figura tendría necesariamente se no estuviera aislada". Trata-se de escapar do figurativo em direção a um puro figural, por extração ou isolamento. Ao observar que o figurativo (a representação) implica a relação entre uma imagem e o objeto que ela deve ilustrar, mas também a relação de uma imagem com outras imagens em um conjunto composto que dá a cada uma o seu objeto, Deleuze ressalta que a narrativa é o correlato da ilustração, posto que "entre dos figuras, para animar el conjunto ilustrado, siempre se desliza, o tiende a deslizarse, una historia" e sintetiza: “aislar es el médio más sencillo, necesario aunque no suficiente, para romper con la representación, cascar la narración, impedir la ilustracón, liberar la Figura, atenerse al hecho" (p.14).

Um equivalente deste procedimento, que, para Deleuze, é o modo mais simples de romper com a representação, pode ser encontrado neste conto, ao percebermos que o narrador, centrado no presente imediato da personagem e evitando o mergulho interior, não narra uma história. $\mathrm{O}$ conto é a narrativa de um narrador-personagem que torna visível algo que ele visualiza a partir do outro. $\mathrm{O}$ narrador age como um artista plástico que usa, no lugar do pincel, a palavra para construir a visibilidade de algo visualizado em segredo, pois é algo que ele vê a partir do outro, mas não descreve.

Não há uma relação de sujeito e objeto entre o narrador e o que ele vê. O visível que ele quer dar a ver, em alguns momentos, escapa-lhe: "O que eu quero olhar diretamente, pela força extraordinária do ancião, não existe neste instante. Ele não quer” (LF, p.94).

Marilena Chauí (1994, p.468-9), ao discutir sobre a filosofia e a arte nos textos de Merleau-Ponty, considerou que o laço que amarra num tecido único experiência, criação, origem e Ser é o laço que prende o Espírito Selvagem e o Ser Bruto. Para falar do entrelaçamento entre o Espírito Selvagem e o Ser Bruto, primeiro os definiu. Entre outras palavras usadas por Chauí para defini-los, destacamos: Espírito Selvagem "é o espírito de práxis que quer e pode alguma coisa, o sujeito que não diz 'eu penso', e sim 'eu quero', 'eu posso', mas que não saberia como concretizar isso que quer e pode senão querendo e podendo, isto é agindo"; o Ser Bruto "é ser de indivisão, desconhecendo a separação entre sujeito e objeto, alma e corpo, consciência e mundo. Indiviso, no entanto, é pura diferença interna e não positividade idêntica a si mesma".

Ser Bruto e Espírito Selvagem, abraçados e enlaçados, "são a polpa carnal do mundo, carne de nosso corpo e carne das coisas". Esmiuçando um pouco mais: 
Carne: habitadas por significações, as coisas do mundo possuem interior, são fulgurações de sentido, como as estrelas de Van Gogh; como elas, nosso corpo também possui interior, é e faz sentido. Se elas e nós nos comunicamos não é porque elas agiram sobre nossos órgãos do sentido e sobre nossos órgãos do sistema nervoso, nem porque nosso entendimento as transformaram em idéias e conceitos, mas porque elas e nós participamos da mesma carne. A Carne do mundo é o que é visível por si mesmo, dizível por si mesmo, pensável por si mesmo, sem, contudo, ser um pleno maciço, mas, paradoxalmente, um pleno poroso, habitado por um oco pelo qual um positivo contém nele mesmo o negativo que aspira por ser, uma falta do próprio Ser, fissura que se preenche ao cavar-se e que se cava ao preencher-se. Não é pois uma presença plena, mas uma presença habitada por uma ausência que não cessa de aspirar pelo preenchimento e que, a cada plenitude, remete a um vazio sem o qual não poderia vir a ser. É o quiasma do visível e do invisível, do dizível e do indizível, do pensável e do impensável, cuja reversibilidade e diferenciação se fazem por si mesmo (CHAUÍ, 1994, p.469-70).

O narrador vê e comunica-se com um corpo (o velho homem) que, para ele, é e faz sentido, mas porque o conto está estruturado de modo a permitir que aquele que vê e narra também se mostre como corpo que é e faz sentido, o texto, como as estrelas de Van Gogh, é também "quiasma do visível e do invisível, do dizível e do indizível, do pensável e do impensável”.

Comparando mais uma vez com os procedimentos da pintura de Francis Bacon, podemos observar as palavras de David Sylvester sobre o modo como o pintor capta a qualidade das nossas sensações das coisas corpóreas:

À frente dos fundos soturnos, claustrofóbicos e encobertos de seus quadros assomam diante de nós seres cuja presença é tão perturbadora, tão inesperada, tão fugidia, tão exigente quanto as de tantas pessoas que na vida nos confrontam e atormentam com sua portentosa ambigüidade (SYLVESTER, 2006, p.69).

As marcas do fazer neste texto se mostram na própria exposição do narrador olhando insistentemente o outro e tomando nota: "Meus olhos ardem e a claridade é 
alta, persistente"/ "Eu anotava tudo, já em discriminar: a garrafa era outra, o criado de casaca, a luz aureolava a cabeça robusta de Plutão que se movia agora com curiosidade, guloso e atento".

Como o espaço em obra do qual Alberto Tassinari (2001, p.61) considera que "imita o fazer da obra", no espaço da folha onde está exposta a enunciação do narrador, o texto não imita uma história de um homem velho, mas o fazer do narrador que narra o visível.

Carlos Mendes de Sousa (2000, p.328), divisando nas personagens da escritora Clarice Lispector um mesmo fascínio pelo ato criador, considerou-se conduzido a um impulso hemenêutico que o "leva a entrever as personagens claricianas manifestando-se (lendo o mundo) como se escrevessem textos". Este impulso, no nosso entender, cabe bem a um leitor deste conto, pois o narrador-personagem age como se estivesse vendo e ao mesmo tempo escrevendo o que vislumbra a partir do visto.

$\mathrm{Na}$ literatura brasileira, desde a publicação de Memórias sentimentais de João Miramar, fala-se em linguagem cinematográfica para se reportar ao texto literário. $\mathrm{Na}$ narrativa de "O jantar", o olhar do narrador funciona como uma câmera filmadora que ora fixa o homem velho com uma certa distância ("Quando fitei-o de novo ele estava em plena glória do jantar”); ora aproxima-se o máximo que pode (“Com a mão pesada e cabeluda, onde na palma as linhas eram cravadas com tal fatalidade, faz um gesto de pensamento"); e ora, ainda, gira em torno do restaurante ("O restaurante parecia irradiar-se com dupla força sob o tilintar dos vidros e talheres"). Podemos observar, então, que o modo como o narrador descreve o que ele vê faz os seus olhos se assemelharem a um tipo de olho-câmera funcionando em zoom: em alguns instantes aproximando-se, conseguindo, neste movimento, registrar as linhas cravadas das mãos do outro, as pupilas doces e cansadas, o azeite que lhe umedece os lábios, a lágrima que desce dos seus olhos, os dentes postiços, e, em outros, afasta-se, girando em torno do restaurante e sobre ele mesmo, indicando que se encontra sentado, comendo, olhando, anotando.

Roberto Corrêa dos Santos (1986, p.47), ao analisar "O jantar", observou, de imediato, que "o conto não se conclui", mas logo em seguida riscou esta observação, acrescentando que "mantê-la implicaria ter um critério para dizer da falha ou da inteireza de algo que é o que ali está, e não outro que poderia ser, possível e desejado". Ele divide sua leitura em três tópicos: "Dos recursos", "Do sujeito observado" e "Do sujeito observador". Quanto aos recursos, para o crítico, é “como que por um processo 
cinematográfico" que a narrativa se desenvolve, porém, ressalta que as coincidências entre o processo literário e o cinematográfico

são, em verdade, muito mais de intenção (ambos os discursos pretendem mostrar) que de recursos, já que cinema e literatura trabalham com diferentes modos de linguagem. Apesar da menor aparição em cena do condutor, este conto de Clarice examina não o mostrado, mas o próprio olho que acompanha. A câmera, enfim, é que é falada (SANTOS, 1986, p.47).

Há um jogo freqüente de justaposição das imagens do velho e da carne que está no prato do observador, pois logo após o narrador observar o velho abocanhando a carne, olha para a carne do seu próprio prato: "Em breve levava um pedaço à certa altura do rosto e, como se tivesse que apanhá-lo em vôo, abocanhou-o num arrebatamento de cabeça. Olhei para o meu prato" (LF, 91-2).

Importante notar uma observação de Regina Pontieri (2001, p.21) sobre a narrativa de Clarice Lispector ao destacar que a autora "configura sua poética do olhar como atividade reversível entre visão e paladar, como ato de comer com os olhos e olhar com a boca". Pode-se, então, aplicar a esta poética a observação de Alfredo Bosi (1988, p.66), ao tratar do olhar fenomenológico, quando destaca que "o olho não está isolado, o olhar está enraizado na corporeidade, enquanto sensibilidade e enquanto motricidade", ressaltando que o narrador se nega a "olhar com a boca" a carne crua do seu prato no sentido de negar o mergulho no interior da personagem.

Comer (o alimento) e olhar (o velho homem) são dois movimentos do narrador que quase se confundem, mas o prato que o narrador come com os olhos é o outro:

Inclino-me sobre a carne, perdido. Quando finalmente consigo encará-lo do fundo de meu rosto pálido, vejo que também ele se inclinou com os cotovelos apoiados sobre a mesa, a cabeça entre as mãos. E exatamente ele não suportava mais. As sobrancelhas grossas estavam juntas. A comida devia ter parado pouco abaixo da garganta sob a dureza da emoção, pois quando ele pode continuar fez um gesto terrível de esforço para engolir e passou o guardanapo pela testa. Eu não podia mais, a carne no meu prato era crua, eu é que não podia mais. Porém ele - ele comia (LF, p.93). 
É o próprio narrador quem nos diz que a carne do seu prato é crua. A este respeito, podemos nos reportar às idéias de Antonio Candido (1985), presentes no capítulo "Estímulos da criação literária" de seu livro Literatura e sociedade, sobre a ocorrência do alimento na literatura do primitivo e do civilizado para ressaltar que no conto de Clarice Lispector é o aspecto simbólico do alimento que está em destaque. A "carne crua" do prato do narrador confunde-se com o alimento que o "velho homem" está comendo, mas ultrapassa o sentido puramente denotativo para assumir o sentido conotativo de que a carne que o narrador rejeita é aquilo que ele não descreve, mas nos deixa ver.

Interessante notar que na ilustração de Cyro del Nero para este conto vemos um homem sentado à mesa, de frente para o prato, inclinado, como na descrição do conto: “com os cotovelos apoiados sobre a mesa, a cabeça entre as mãos". A imagem ilustra o instante em que os dois personagens, narrador e velho homem, se assemelham na mesma imobilidade silenciosa:

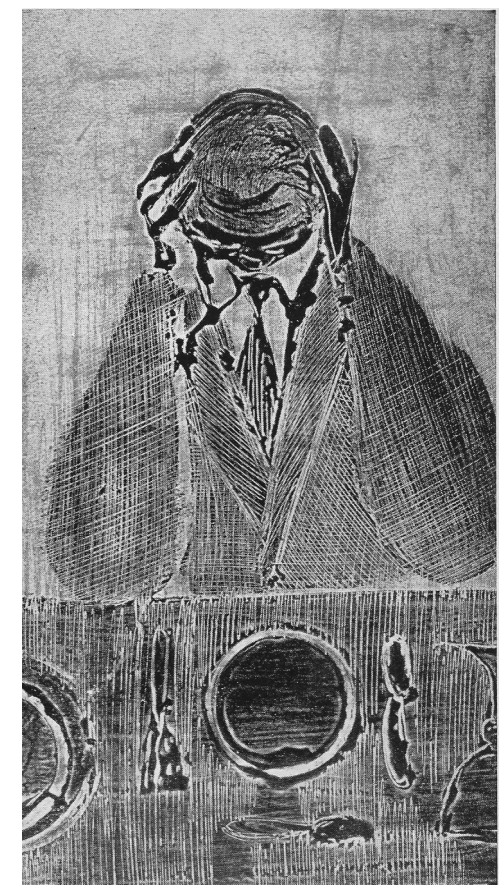


Observando atentamente o velho homem, o narrador detém-se em muitos instantes em que o velho se imobiliza e leva o guardanapo aos olhos:

E exatamente como se não suportasse mais - o que? - pega rápido o guardanapo e comprime as órbitas dos olhos com as mãos cabeludas. Parei em guarda. Seu corpo respirava com dificuldade, crescia. Tira afinal o guardanapo da vista e olha entorpecido de muito longe. Respira abrindo e fechando desmesuradamente as pálpebras, limpa os olhos com cuidado e mastiga devagar o resto da comida ainda na boca (LF, p.92).

Mas, logo o velho volta a comer: "Daqui a um segundo, porém, está refeito e duro, apanha uma garfada de salada com o corpo todo [...]". Constantemente comendo e imobilizando-se: "Interrompe-se um instante, enxuga de novo os olhos, balança brevemente a cabeça - e nova garfada de alface é apanhada no ar" / "Mas eis que o velho se imobiliza de novo como se tivesse o peito contraído e barrado. Sua violenta potência sacode-se presa. Ele espera. Até que a fome parece assaltá-lo e ele recomeça a mastigar com apetite, de sobrancelhas franzidas". / "De repente ei-lo a estremecer todo, levando o guardanapo aos olhos e apertando-os numa brutalidade que me eleva" (LF, p. 92). O narrador fala de um "aperto insuportável na garganta" que ele próprio também sente:

Abandono com certa decisão o garfo no prato, eu próprio com um aperto insuportável na garganta, furioso, quebrado em submissão. Mas o velho demora pouco com o guardanapo nos olhos. Desta vez, quando tira sem pressa, as pupilas estão extremamente doces e cansadas, e antes dele enxugar-se - eu vi. Vi a lágrima (LF, p.93).

Além de flagrar a lágrima nos olhos do velho homem, o narrador também flagra o choro:

O velho comedor de crianças pensa nas suas profundezas. Com palidez vejo-o levar o guardanapo à boca. Imagino ouvir um soluço. Ambos permanecemos em silêncio no centro do salão. Talvez ele tivesse comido depressa demais. Porque, apesar de tudo, não perdeste a fome, hein!, instigava-o eu com ironia, cólera e 
exaustão. Mas ele se desmoronava a olhos vistos. Os traços agora caídos e dementes, ele balançava a cabeça de um lado para o outro, de um lado para o outro sem se conter mais, com a boca aberta, os olhos cerrados, embalando-se - o patriarca estava chorando por dentro. A ira me asfixiava (LF, p.94-5).

O alimento preso na garganta metaforiza o silêncio da narrativa que dá a ver um fato sem narrar sua história.

O narrador utiliza a expressão "cabeça robusta de Plutão" para se referir ao velho. Se observarmos que, para a astrologia analítica, Plutão é "o príncipe das trevas", "o símbolo das profundezas de nossas trevas interiores, ligadas à noite da alma, isto é, às camadas mais arcaicas da Psique" ${ }^{" 30}$, o sentido simbólico da expressão pode nos remeter às profundezas "das trevas interiores" do homem velho, mas também diz respeito às "trevas interiores" do narrador angustiado ("Eu próprio com um aperto insuportável na garganta, furioso, quebrantado em subimissão").

Em oposição à tristeza do velho homem, o narrador focaliza uma mulher bela e sorridente. A primeira vez é logo após a chegada do velho homem, ele conta que ela ria de boca cheia: "Perdi-o de vista e enquanto comia observei de novo a mulher magra de chapéu. Ela ria de boca cheia e rebrilhava os olhos escuros". O narrador informa que a observou "de novo", reportando-se a um momento anterior à narrativa propriamente dita. Depois, na passagem em que destaca pela segunda vez seu sorriso e agora também sua beleza: “... a mulher do chapéu grande sorria de olhos entrefechados, tão magra e bela". E na última vez, quando fala de si mesmo e focaliza a mulher agora séria: "Meus olhos ardem e a claridade é alta, persistente. Estou tomado pelo êxtase arfante da náusea. Tudo me parece grande e perigoso. A mulher magra cada vez mais bela estremece séria entre as luzes" (LF, p.94).

Se observarmos que na obra Laços de família um aspecto comum é o conflito do homem em família, no conto "O jantar" este tema está presente a partir da falta. O narrador é alguém que fala a partir de um patriarca, no momento, em que é visto sofrendo uma perda que não é narrada. Mas, mostrar o outro é mostrar-se: "O que eu quero olhar" / "Eu próprio com um aperto insuportável na garganta"/ "A ira me

\footnotetext{
${ }^{30}$ No Dicionário dos Símbolos, de Jean Chevalier e Alain Gheerbrant (2006, p.725), lemos: "Para a astrologia analítica, Plutão, o príncipe das trevas, é o símbolo das profundezas de nossas trevas interiores, ligadas à noite da alma, isto é, às camadas mais arcaicas da Psique. Quando Jung declara que o homem civilizado ainda arrasta atrás de si a cauda de um sáurio, fixa a imagem infernal dessa região ancestral do indivíduo governada por este planeta".
} 
asfixiava"/ "Eu é que já comia devagar, um pouco nauseado sem saber porque, participando também não sabia de que" / "Ambos permanecemos em silêncio no centro do salão" / "Instigava-o eu com ironia, cólera e exaustão" (LF, p.95).

Ao tratar do tópico "Do observado" em sua leitura do conto, Roberto Corrêa dos Santos (1986, p.54) estabelece, a partir da organização dos enunciados textuais, um quadro contendo os pares Fraqueza/Potência, Interrupção/Prosseguimento e Líquidos/Sólidos, sem considerá-los elementos excludentes, e conclui: "a atitude, linguagem, a angústia e a transformação por que passa o narrador, tão 'pouco' mostrado em cena, mas presente o tempo todo no discurso, deve-se ao fato de reconhecer no outro o dilema do homem, a permanente batalha entre viver e morrer". Na análise do terceiro tópico, "Do sujeito observador", o crítico não tem dúvida de que "a tensão vida e morte tem papel decisivo no processo de construção das significações do texto" (p.57).

Em alguns momentos, ressalta-se, na narrativa, a diferença entre o narrador e o velho homem, especialmente, sobre o modo como cada um degusta o alimento, porém, se lembrarmos que a carne no prato do narrador é "crua", esta diferença é relativa. Se o homem velho come com ferocidade a carne de seu prato, e o narrador nos faz perceber com repugnância esse aspecto, como destacou Arnaldo Franco Junior (1999, p.132-3), isso se dá porque a narrativa faz o leitor partilhar "uma mesma perspectiva comum, um núcleo de valores necessariamente situados nos limites do imaginário social da classe média - como kitsch, nota de mau gosto e vulgaridade que, por sua dissonância no ambiente do restaurante, repugna e atrai", mas, igualmente feroz, e às vezes grosseiro, é o narrador ao "comer com os olhos": "Parei em guarda" (LF, p.92)/ "Desta vez foste bem agarrado, velho" (LF, p.94).

O visível deste conto remete ao invisível da perda, nem sempre percebido por leitores que se prendem apenas às muitas descrições do homem velho, amedrontador e mal-educado: "Era alto, corpulento, de cabelos brancos, sobrancelhas espessas e mãos potentes. Num dedo o anel de sua força" / "Voz sem réplicas possíveis" / "O grande cavalo apóia a cabeça na mão" / "O velho comedor de crianças" / "Embora ainda enorme e ainda capaz de apunhalar qualquer um de nós" / "Apalpava o bife com as costas do garfo, quase o cheirava, mexendo a boca de antemão" / "Mastigando de boca aberta, passando a língua pelos dentes".É a partir dessa "potência" que o narrador vê a "ruína". 
Para o narrador, o outro "diz com a mímica o máximo que pode", mas ele não compreende. Ele descreve o velho a partir de sua aparência, das escolhas feitas no restaurante, da entonação de sua voz, das expressões faciais e dos gestos. Parece iniciar uma narrativa intimista, mas acaba por assumir que não consegue: "Abandono com certa decisão o garfo no prato, eu próprio com um aperto insuportável na garganta, furioso, quebrado em submissão" (LF, p.92-3). Nesses instantes em que a narrativa chama atenção para o "eu" que olha, o narrador abandona a posição de "olho-câmera" que tudo capta. Ressalta-se, então, a limitação de sua visão: "Eu mesmo, tão atento estivera a ele, que não o vira tirar o dinheiro para pagar, nem examinar a conta, e não notara a volta do 'garçon' com o troco" (LF, p.95).

Ao final do conto, após descrever a saída do velho homem ("Sem que eu possa fazer nada, põe o chapéu acariciando a gravata ao espelho. Atravessa o aspecto luminoso do salão, desaparece"), o narrador acrescenta:

Mas eu sou um homem ainda.

Quando me traíram ou assassinaram, quando alguém foi embora para sempre, ou perdi o que de melhor me restava, ou quando soube que vou morrer - eu não como. Não sou ainda esta potência, esta construção, esta ruína. Empurro o prato, rejeito a carne e seu sangue (LF, p.51).

Ao final, o narrador fala de traição, assassinato, abandono, solidão e perda como se tudo isso já lhe tivesse acontecido ("quando me traíram ou assassinaram, quando alguém foi embora para sempre, ou perdi o que de melhor me restava") e da morte como perigo imanente ("quando soube que vou morrer"), revelando-se sujeito da perda, mas também da impotência: "eu não como". Ao mesmo tempo semelhante e diferente do velho homem: "Não sou AINDA esta potência, esta construção, esta ruína". Sobre o velho homem o narrador observou que "apesar de tudo não perdeste a fome, hein". Mas ele, pelo contrário, empurra o prato, rejeita a carne e seu sangue. Esta sua impotência faz a sua diferença em relação à "potência" que ele vê no velho homem, corpo ambíguo, ao mesmo tempo "potência" e "ruína" que o narrador nos dar a ver.

Sobre a identificação entre narrador e homem velho, Santos (1986, p.54), ao destacar que "falar de algo é falar de si", observa que o "narrador vê-se no outro, entendido como um duplo", o que, do ponto de vista da psicanálise, "consiste, 
sintomaticamente, tanto no desdobramento de uma existência que se vê espelhada na outra, quanto na imediata relação que tal desdobramento tem com a perda e com a morte".

Podemos falar um pouco mais da reversibilidade nesta narrativa. Há o par comer e olhar. O personagem come a carne (o alimento) e o narrador olha a "carne crua" (o velho homem). E há o par comer e narrar. O narrador "come com os olhos", assume a visão exterior (torna visível), mas não "come com a boca", não assume a visão interior (não diz o visível). Mostra a dor, mas não diz a dor. Dizê-la é falar da própria dor que se sente, e ele próprio tem um aperto insuportável na garganta. Metaforicamente, recusar a carne e seu sangue é recusar a visão interior diante do contexto de dor em que se encontra este narrador ("Quando me traíram ou assassinaram, quando alguém foi embora para sempre, ou perdi o que de melhor me restava, ou quando soube que vou morrer - eu não como").

A cena do jantar é silenciosa, apenas em dois momentos o narrador relata o som: primeiro, quando nos apresenta a voz do velho homem (“ - Não é este o vinho que eu mandei trazer") (LF, p.92); e segundo, quando, desviando a atenção concentrada na imagem do velho homem, olha em torno do restaurante e ouve o som das coisas ao seu redor, como se tivesse acionado o áudio de seu olho-câmera:

Nada mais acontecia. O restaurante parecia irradiar-se com dupla força sob o tilintar dos vidros e talheres; na dura coroa brilhante da sala os murmúrios cresciam e se apaziguavam em vaga doce, a mulher do chapéu grande sorria de olhos entrefechados, tão magra e bela, o "garçon" derramava com lentidão o vinho no copo. Mas eis que ele faz um gesto (LF, p.94).

Não há descrição do espaço do restaurante, há apenas alusão a algumas sensações experimentadas: "Estou tomado pelo êxtase arfante da náusea. Tudo me parece grande e perigoso" (LF, p.94), revelando-nos o modo como ele percebe as coisas no instante atual.

Outro personagem visualizado é o garçon, descrito em diferentes situações de submissão diante do velho ("sussurando palavras amáveis", "abaixando-se para apanhálo", "cortês") e é também referido como "criado": "A um gesto mais vivo do criado" (LF, p.91) / "O criado curvou a cabeça luzente com sujeição ao agradecimento, saiu inclinando-se, e eu respirava com alívio" (LF, p.93.). Essas situações do garçon 
reforçam ainda mais a imagem de poder do velho. Porém, é desse personagem que o narrador mais se aproxima em termo de mergulho na consciência:

Por um instante o 'garçon' cobre minha visão do velho e vejo apenas as asas negras duma casaca: sobrevoando a mesa, vertia vinho vermelho na taça e aguardava de olhos quentes - porque lá estava seguramente um senhor de boas gorjetas, um desses velhos que ainda estão no centro do mundo e da força (LF, p. 93. Grifo nosso).

A marca do travessão no discurso contribui para a observação de que o narrador expõe aqui a intenção do garçon por trás de seus gestos submissos.

Interessante notar que o silêncio deste conto se faz sentir no texto da escritora "A explicação inútil”, a respeito dos contos de Laços de família, publicado na segunda parte de A legião estrangeira. Sobre "O jantar", as palavras de Clarice Lispector são: “De 'O Jantar' nada sei” (LE, p.174).

Se nos voltarmos agora para o momento histórico brasileiro durante o intervalo de escrita e publicação do conto, poderemos, como fez Auerbach (2004, p.407) em relação ao romance Le rouge et le noir, de Stendhal (1830), apontando no enfado que ronda a mansão do Marquês de La Mole "um fenômeno político e sócio-histórico da Restauração", sugerir que há na atmosfera de silêncio do texto algo da atmosfera política do período do Estado Novo no Brasil, já que o conto foi publicado pela primeira vez em 1946, mas, como informa Teresa Montero Ferreira (1999, p.172), “escrito em $1943{ }^{\prime \prime 31}$.

No Brasil, vivia-se os anos de ditadura do Estado Novo, de cuja Carta de 1937, como ressaltou Boris Fausto, o segredo estava nas "disposições finais e transitórias":

O artigo 186 das 'disposições finais e transitórias' declarava em todo o país o estado de emergência, suspendendo assim as liberdades civis garantidas formalmente pela própria carta constitucional. Outro preceito transitório, mais tarde prolongado definitivamente, autorizava o governo a aposentar funcionários

31 Em 1943 Clarice Lispector publicou o romance Perto do coração selvagem. Curiosamente, no segundo capítulo deste romance, uma passagem que narra o modo como, um dia, Joana se sentiu ao ver um homem guloso comento com ferocidade encerra semelhanças com o conto "O jantar". A narradora informa que Joana "sabia que o homem era uma força. Não se sentia capaz de comer como ele, era naturalmente sóbria, mas a demonstração a perturbava" (PCS, p.26-7). 
civis e militares, "no interesse do serviço público ou por conveniência do regime"" (FAUSTO, 2006, p.365).

A tensão entre opacidade e o instante libertador, para Luiz Costa Lima (1970), é a tensão básica da obra clariciana. No conto, a tensão se mostra no movimento de expansão e retidão do velho homem que come com ferocidade a carne de seu prato e várias vezes imobiliza-se chorando. No narrador, a tensão é observada em seu movimento de comer ferozmente com os olhos, mas deter-se para não comer com a boca a carne crua de seu próprio prato.

Paul Ricoeur, ao escrever sobre a compreensão da violência, ressaltou que

a psicologia sumária do empirismo que gravita em torno do prazer e da dor, do bem-estar e da felicidade, omite o irascível, o gosto do obstáculo, a vontade de expansão, de combate e de dominação, os instintos de morte e, sobretudo, essa capacidade de destruição, esse apetite de catástrofe que é a contrapartida de todas as disciplinas que fazem do edifício psíquico do homem um equilíbrio estável e sempre ameaçado (RICOEUR, 1968, p.227).

A narrativa de Clarice Lispector, pelo contrário, mostra-nos a vontade de expansão como momento privilegiado, o narrador do conto deseja com vigor ver a vontade de expansão surgir mesmo nos momentos de imobilidade do velho homem: "De repente ei-lo a estremecer todo, levando o guardanapo aos olhos e apertando-os numa brutalidade que me enleva...” (LF, p.92).

A expressão "velho comedor de crianças" parece não esconder uma referência ao comunismo para se referir ao homem velho, porém, por outro lado, há uma descrição do poder deste homem, captada pelos olhos do garçon, que não condiz com um velho comunista: "lá estava seguramente um senhor de boas gorjetas, um desses velhos que ainda estão no centro do mundo e da força".

Importante observar que no contexto do Estado Novo (1937-1945) o poder centralizador tinha conseguido se realizar plenamente no Brasil. A esse respeito, Boris Fausto escreveu que "o Estado Novo concentrou a maior soma de poderes até aquele momento da história do Brasil independente. A inclinação centralizadora, revelada desde os primeiros meses após a Revolução de 1930, realizou-se plenamente" (p.366). Como exemplo desta centralização, o historiador, ao tratar do tema "Estado e 
Sociedade" no período, observou que o Conselho Federal do Comércio Exterior, (CFCE), criado em 1934, “com o objetivo de centralizar a política de comércio exterior", com o tempo "acabou constituindo-se também em uma das principais vias de acesso ao poder por parte dos grupos privados, especialmente os industriais" (p.367).

Em 1941, Clarice Lispector era estudante de Direito e publicou na revista Época, como informa Teresa Montero Ferreira (1999), organizada pelos alunos da faculdade, o texto "Observações sobre o direito de punir" que começava com uma importante compreensão do poder soberano: "Não há direito de punir. Há apenas poder de punir. O homem é punido pelo seu crime porque o Estado é mais forte que ele, a guerra, grande crime, não é punida porque acima dum homem há os homens acima dos homens nada mais há" (OE, p.45).

Restringindo-nos aos fatos históricos, é importante ao menos destacar que Clarice trabalhou na Agência Nacional, pertencente ao DIP (Departamento de Imprensa e Propaganda), órgão do governo de Getúlio Vargas responsável pela censura; que em 1942 ela trabalhou em $A$ Noite, na ocasião, órgão de elogio ao governo; que o Estado Novo, como informou Boris Fausto (2006, p.376), "perseguiu, prendeu, torturou, forçou ao exílio intelectuais e políticos, sobretudo da esquerda e alguns liberais", mas não fez isso de modo deliberado, "pois seus dirigentes perceberam a importância de atrair setores letrados a seu serviço"; que Clarice se naturalizou brasileira somente no ano de 1943, após escrever ao presidente Getúlio Vargas, a 3 de junho de 1942, solicitando redução do prazo de um ano previsto pela lei $n^{\circ} 1.350$, de 16/6/1939; que eram anos de guerra; que o Brasil entrou na guerra em 1942; que Clarice esteve de 1944 até 1946 (ano em que o conto foi publicado) em Nápoles; que a guerra ...

Morando fora do Brasil, Clarice Lispector não deixou de receber notícias sobre o país. A esse respeito, na introdução de sua dissertação, Valéria Franco Jacintho (1997), ressaltou que a jornalista Bluma Bluma, apesar de também estar morando fora do Brasil, em Paris, mantinha Clarice informada sobre a situação da política brasileira:

Bluma comenta com Clarice a coalizão entre Dutra e U.D.N (União Democrática Nacional), partido conhecido por fazer oposição a Getúlio Vargas: 'Do Brasil, a última notícia que tivemos foi que não há mais café no país e que a U.D.N. terminou entrando em acordo com Dutra, coalizão oficial'. E pinta um triste retrato da violência no Brasil, caminho seguro para a volta à ditadura: "Não sei se os jornais daí publicaram uns telegramas sobre os últimos acontecimentos no 
nosso querido Brasil - tiros, prisões, feridos. A polícia sob controle do exército. Tudo isso nos faz chegar à conclusão de que se já não se impôs a ditadura militar, não demoraremos muito - questão de dias, talvez' (JACINTHO, 1997, p.17).

A primeira citação é de uma carta escrita de Paris no dia 22 de julho de 1946; a segunda, também de Paris, data de 2 de setembro de 1946. Um outro aspecto que podemos observar nas cartas enviadas por Bluma Wainer a Clarice Lispector é seu interesse em manter Clarice informada também sobre os amigos que têm em comum, referindo-se em diversas cartas ao amigo escultor Cheschiatti.

Mas, além de ter vivido no Brasil durante o Estado Novo, de ter vivenciado mais de perto a Segunda Guerra, em Nápolis, inclusive, prestando serviço voluntário na Seção de Serviço Social do Serviço de Saúde da F.E.B., e de ter sido informada sobre a situação política brasileira no ano em que publicou o conto, entre outras atividades de interesse artístico, Clarice Lispector leu A porta estreita, de Andre Gide, as cartas de Katherine Mansfiel, As sombras das rap'rigas eim floire, como traduziram os portugueses, de Marcel Proust; freqüentou concertos e cinemas; conheceu pintores (De Chirico, Zina Aita, que a retrataram, ${ }^{32}$ e Leonor Fini). Visitou Florença, onde viu obras de Michelangelo, Botticelli, Rafael, Cellini, Bruneleschi, Donatelo. Mudou-se para Berna-Suíça.

O narrador de "O jantar" não se exclui como participante de uma dada situação ("Eu é que já comia devagar, um pouco nauseado sem saber porque, participando também não sabia de quê"). A situação política brasileira pode estar na atmosfera do conto, especialmente, no sentido de que este narrador se sabe participante de uma dada situação, mas a narrativa não é alegórica. $O$ texto não funciona como alegoria da repressão. Em seu silêncio gritante, o texto, mais do que expor a dor, alude ao grito preso na garganta.

Deleuze (2005, p.45) observou que Francis Bacon, em sua pintura, elimina o “"sensacional', es decir, la figuración primaria de lo que provoca una sensación violenta. Tal es el sentido de la fórmula: he querido pintar el grito antes que el horror".

Em "O ovo e a galinha", texto que analisamos como uma narrativa na qual a protagonista prepara o ovo doméstico para o café-da-manhã e o ovo texto na

\footnotetext{
${ }^{32}$ Em carta de 07 de fevereiro de 1945, enviada de Nápoles, Clarice Lispector conta a Lúcio Cardoso que vai posar para a artista plástica brasileira Zina Aita, que participou da Semana de Arte Moderna. Em uma outra carta, de 9 de maio do mesmo ano, enviada de Roma às irmãs Elisa e Tânia, conta como foi a última vez que posou para o artista grego De Chirico, enquanto a Segunda Guerra Mundial chegava ao fim.
} 
imaginação, pensando sobre importantes questões que envolvem o fazer artístico, há a seguinte passagem: "O ovo é uma exteriorização [...]. O ovo expõe. - Quem se aprofunda num ovo, quem vê mais do que a superfície do ovo está querendo outra coisa: está com fome" (LE, p.56). Pensando o ovo como realidade empírica e relacionando esta passagem citada com o que observamos no conto "O jantar", consideramos que o narrador, ao rejeitar a "carne e seu sangue", simbolicamente, rejeita aprofundar-se na dor, o que faria uma narrativa que seguisse o parâmetro do realismo tradicional. Eliminando o sensacionalismo, como Deleuze observa na pintura de Bacon, o narrador clariciano privilegiou o grito e não o horror.

Sobre o "El hombre y la nina" (1963), de Bacon, Deleuze observou que Russell disse muito bem ao se perguntar:

Esta niña ¿há sido repudiada por su padre que no la perdonará? ¿Es acaso esta mujer que le hace frente cruzados los brazos la guardiana de ese hombre, aun cuando él se retuerza sobre su silla y mire en otra dirección? ¿Es una anormal, un monstruo humano, de regreso para atormentarlo, o es un personaje puesto sobre un pedestal, un juez listo para dictar su sentencia? (DELEUZE, 2005, p.75).

Observando que Russel, todas as vezes, recusa a hipótese que reintroduziria uma narração no quadro, Deleuze o cita: "No lo sabremos nunca, e incluso no deberíamos desear saberlo" (p.75-6). Para Deleuze, pode-se dizer que o quadro é a possibilidade de todas essas hipóteses ou narrações ao mesmo tempo. "Pero es porque él está fuera de cualquier narración" (p76).

Sobre este conto de Clarice Lispector também podemos fazer muitas perguntas. Há um clima de opressão na narrativa, mas a opressão não foi narrada. A narrativa faz ver, sentir, ouvir o silêncio. Lembramos da "linguagem tácita" de Merleau-Ponty porque o peso da significação deste texto se deixou ver em sua estrutura singular. $\mathrm{O}$ narrador torna visível a partir da carne crua de seu parto - o velho homem - a ambigüidade de se ser ao mesmo tempo "potência" e "ruína", de se ter um grito preso na garganta e resistir. Por não se aprofundar na dor, mas naquilo que ele intui ao ver um velho homem que come e sofre, o narrador revelou-nos o invisível e, nesse sentido, o conto, sendo uma obra literária, "quase assume a irradiação muda da pintura".

\section{"Devaneio e embriaguez duma rapariga"}


Na carta de 30 de março de 1955 de Fernando Sabino para Clarice, dando notícia da leitura dos contos que deveriam ser entregues a Simeão Leal para publicação, lemos: “Li em voz alta, para mim mesmo, o da portuguesinha, que pena Mário de Andrade já ter morrido! E como ele perdeu tempo!”. Ao relembrar esta passagem, pretendemos apenas observar que uma primeira versão do conto "Devaneio e embriaguez duma rapariga”, publicado pela primeira vez na obra Laços de família (1960), já estava pronta em 1955.

O conto inicia-se com a apresentação da personagem no espaço físico, o quarto, penteando-se de frente para uma penteadeira de três espelhos. A narradora compõe uma cena que reúne simultaneamente imagens internas e externas do quarto ("Pelo quarto parecia-lhe estarem a se cruzar os elétricos, a estremecerem-lhe a imagem refletida [...]. Cá fora, duma janela mais alta, caiu à rua uma coisa pesada e fofa"). A descrição da imagem do corpo da protagonista refletida nos três espelhos é descontínua, misturandose aos objetos, compondo um todo fragmentado.

No início, a presença dos espelhos refletindo a mulher sozinha em casa, cena que será desenvolvida em seguida na narrativa, chama-nos atenção para uma consideração de Roger Fry sobre a imagem espelhada, ao destacar que nela

é mais fácil nos abstrairmos por completo e observar a cena como um todo. É então que, de imediato, ela adquire uma qualidade visionária e nos tornamos de fato espectadores, que não selecionam o que vêem, mas vêem tudo de maneira equivalente. Com isso passamos a notar inúmeras aparências, que antes nos teriam escapado, por causa da perpétua economia efetuada pela sensação das impressões assimiláveis, o que na vida real realizamos por meio de processos inconscientes. Portanto, em certa medida, o enquadramento do espelho transforma a cena refletida, fazendo com que uma cena de nossa vida real se aproxime de uma vida imaginada. O enquadramento do espelho faz de sua superfície uma obra de arte muito rudimentar, uma vez que nos ajuda a alcançar a visão artística (FRY, 2002, p.56).

Em outra obra de Clarice Lispector, Um sopro de vida (1978), a personagem Autor também trata da diferença entre captar o que está refletido no espelho e captar a coisa viva: 
AUTOR: Tentar possuir Ângela é como tentar desesperadamente agarrar no espelho o reflexo de uma rosa. No entanto bastava eu ficar de costas para o espelho e teria a rosa de per si. Mas aí entra o frígido medo de ser dono de uma realidade estranha e delicada de uma flor (SV, 43-4).

Para Merleau-Ponty (2004, p.23), essa diferença é a magia especial do espelho para um olhar não cartesiano. Ele define o espelho como "instrumento de uma universal magia que transforma as coisas em espetáculos, os espetáculos em coisas, eu em outrem e outrem em mim". Ao reportar-se ao espelho na pintura, Merleau-Ponty considerou que, "com freqüência, os pintores sonharam sobre os espelhos porque, sob 'esse truque mecânico' como sob a perspectiva, reconheciam a metamorfose do vidente e do visível, que é a definição da nossa carne e da vocação deles".

O conto inicia com essa "magia do espelho" transformando a protagonista: "Os olhos não se despregavam da imagem, o pente trabalhava meditativo, o roupão aberto deixava aparecerem nos espelhos os seios entrecortados de várias raparigas” (LF, p.11).

$\mathrm{Na}$ enunciação da narrativa, a partir da sintaxe e do vocabulário empregados, é possível percebermos uma entonação da língua portuguesa falada em Portugal. Observamos que para este texto podemos repetir aquilo que Michel Butor (1974, p.233) classifica como "ceder à voz" ao considerar que "o escritor cede à voz quando as formas que ele emprega nos levam naturalmente, ao lermos exterior ou interiormente seu texto, a devolver-lhe certas entonações".

No segundo parágrafo do conto, a expressão "Noite!" é o grito do jornaleiro vendendo o jornal na rua Riachuelo, conforme deixa ver a narradora. Esta informação situa-nos no momento inicial da narrativa, contrário ao título do jornal, dia, e no espaço geográfico, um quarto localizado em uma Rua Riachuelo. O parágrafo termina com a personagem entoando uma cantiga em que um pardalzito voa pr'além do Minho, e com a narradora informado o estado emotivo desta personagem, "mas, colérica, fechou-se dura como um leque" (LF, p.11).

Em terceira pessoa, a narradora informa que a rapariga deitou-se, abanando-se impaciente com um jornal. A partir do discurso indireto livre, a enunciação da narradora se confunde com a da personagem em passagens iniciadas pela interjeição "Ai": "Ai, ai, suspirou a rir" (LF, p.11). O diálogo que se segue é fruto da imaginação da personagem ou lembrança de uma cena vivida, pois no instante atual ela está sozinha em seu quarto, e ver-se iniciando um assunto "possível e interessante de palestra" (LF, p.12). Sem que 
a narradora informe detalhes sobre quem é o interlocutor do diálogo imaginado, a protagonista, em um tom de conversa animada, inicia com a saudação "Bons dias, sabes quem veio a me procurar cá à casa?’. Podemos imaginar que a cena se dá entre ela e alguém do seu convívio familiar, mas que não apresenta o mesmo entusiasmo para a conversa visto que a resposta "Pois não sei, quem?" vem acompanhada da seguinte observação da narradora: "Perguntaram-lhe com um sorriso galanteador, uns olhos tristes dessas caras pálidas que a uma pessoa fazem tanto mal” (LF, p.12). A protagonista, irritada, retruca: “A Maria Quitéria, homem!” (Grifo nosso), e a narradora, detalhando os gestos da personagem, complementa, "garrida, de mão à ilharga". Parece que a cena imaginada se passa entre a protagonista e seu duplo. Importante notarmos que, na história do Brasil, houve uma mulher chamada Maria Quitéria que, disfarçada de homem, alistou-se como soldado para lutar no recôncavo baiano contra os portugueses que se recusavam a reconhecer a independência do Brasil. O diálogo ainda prossegue, e como seu interlocutor não conhece Maria Quitéria, pergunta-lhe: “E se m'o permite, quem é esta rapariga?". A narradora em terceira pessoa complementa: "Insistiram ainda galante, mas já agora sem fisionomia". A resposta lacônica e ríspida que encerra a conversa é “Tu!". Ao final, narradora e personagem se confundem: "Cortou ela com leve rancor a palestra, que chatura (LF, p.12. Grifo nosso).

Nas passagens em que a enunciação da narradora confunde-se com a enunciação da personagem temos a impressão de que o texto funciona como um monólogo, técnica narrativa em que, como observou Amariles Gumarães Hill (1976, p.141), “é possível ao narrador exercer-se na linguagem como sujeito enquanto é objeto, falar e falar-se". Além disso, aproximam-se do texto para teatro, e este, como destacou Anatol Rosenfeld (1993, p.22), “apresenta apenas um sistema de coordenadas que deve ser preenchido pela música dos movimentos, pelas inflexões de voz, pelas nuanças indefiníveis da mímica e do gesto". Neste conto, as inflexões de voz podem ser observadas na recorrência da interjeição "Ai”, como em "Ai que quarto suculento! Ela se abanava no Brasil. O sol preso pelas persianas tremia na parede como uma guitarra" (LF, p.12), ou, ainda, no português falado em Portugal, presente tanto na enunciação da narradora quanto da personagem, permitindo a nós leitores brasileiros nos colocarmos como espectadores que assistem à performance improvisada da jovem dona-de-casa. Uma narrativa cuja enunciação oscila entre o distanciamento da terceira pessoa e a aproximação da primeira, fazendo confundir narradora e personagem, pois há momentos em que a narradora marca as falas da personagem com aspas, como por 
exemplo: “QQuem encontrou, buscou', disse-se em forma de rifão rimado, o que sempre terminava por parecer alguma verdade" (LF, p.12), e momentos em que a enunciação da narradora deixa à mostra o improviso, a identidade da narradora fundando-se em confronto com a identidade da personagem: "Na cama a pensar, a pensar, quase a rir como a uma bisbilhotice. A pensar, a pensar. O que? ora, lá ela sabia. Assim deixou-se a ficar" (LF, p.13).

A passagem do tempo na narrativa é rápida e registrada a partir de referências à saída e chegada do marido ao quarto em que se encontra a personagem: "Só acordou com o marido a voltar do trabalho e a entrar pelo quarto adentro. Não quis jantar... dormiu de novo" (LF, p. 12) / "E já que os filhos estavam na quinta das titias em Jacarepaguá, ela aproveitou para amanhecer esquisita... O marido apareceu-lhe já trajado" (LF, p.12)/ "Nessa noite, até dormir, fantasticou, fantasticou: por quantos minutos? Até que tombou: adormecidona a ressonar com o marido" (LF, p.14) (Grifo nosso). Se calcularmos, teremos dois dias inteiros em que a personagem se encontra deitada no quarto, "só se levantando para ir à casa de banhos..." (LF, p.13). Na segunda noite, antes de dormir, a narradora nos informa que a personagem "fantasticou, fantasticou: por quantos minutos? Até que tombou: adormecidona a ressonar com o marido.” (LF, p.14). Vemos aqui a interrogação que causa dissonância na objetividade da narrativa em terceira pessoa. A próxima referência ao tempo não cita o marido, a narradora em terceira pessoa informa: "Acordou com o dia atrazado (sic), as batatas por descascar..." (LF, p.14). Nesta passagem, como em muitas outras, a narrativa oscila entre a narradora de terceira e discurso indireto livre. Entre as tarefas domésticas por fazer, a personagem pensa: “Ai que até me faltei ao respeito! dia de lavar roupa e serzir as peúgas , ai que vagabunda que me saíste!” E a narradora complementa,: “Censurouse curiosa e satisfeita, ir às compras, não esquecer o peixe, o dia atrazado [sic], a manhã pressurosa de sol". As tarefas não serão desenvolvidas no texto, pois o próximo parágrafo dá um salto e, pela primeira vez informando o dia da semana, sábado, passa a narrar no pretérito a saída da esposa com o marido e um negociante rico a uma tasca. Porém, não ocorre a demarcação exata do tempo do acontecimento em relação ao tempo da enunciação. À dissolução do espaço, presente, por exemplo, no quadro La desserte (1908) de Matisse, corresponde aqui o esfacelamento da ação exterior, diante da ênfase no acontecimento recuperado pela consciência da personagem, livre de uma lógica causal. Talvez o sábado já tenha acontecido quando a narrativa iniciou, por isso a protagonista se encontra na cama, sofrendo o efeito do dia seguinte à embriaguez, o que 
explicaria seu mal-estar e todas as sensações descritas: a de corpo crescido, o ouvido sensível aos sons, a sensação do espaço como algo maleável. Situar o tempo do acontecimento em relação ao aqui e agora da enunciação é menos importante do que perceber o modo como ele é apresentado por meio da imaginação da personagem, pois encerra relações com sua competência para as "coisas d'arte", ou, se quisermos usar uma expressão de Roger Fry, para "a vida imaginativa", desvinculada das necessidades obrigatórias de nossa existência efetiva e por isso mesmo distinta da vida real que exige ação reativa e responsabilidade moral.

No primeiro romance da escritora, a personagem Joana se perguntara: "Por que uma casa encerada e limpa deixava-a perdida como num mosteiro, desolada, vagando pelos corredores?” (PCS, p.41). Na relação entre o espaço (exterior) e o pensamento (interior) podemos encontrar uma resposta para esta pergunta: observando que a confusão do pensamento, para Joana, além de trazer certa graça, traz a realidade mesma, pensamos que a casa em desordem é mais fiel à percepção da personagem clariciana de que o pensamento não obedece a uma ordem pré-estabelecida.

Como Joana de Perto do coração selvagem, que "mal sentia que o marido saíra de casa, se transformava, concentrava-se em si mesma", a protagonista de "Devaneio e embriaguez duma rapariga" passa as horas entregues ao próprio pensamento. De si mesma, ela pensa: "Ninguém lhe tiraria cá das idéias que nascera mesmo para outras cousas. Ela sempre fora pelas obras d'arte" (LF, p.16). A preocupação com a casa é esquecida, e a desordem espacial está presente na própria estrutura do conto em relação à dissolução da seqüência temporal.

Contribui para percebermos esse aspecto, observarmos que em outro conto da obra Laços de família, "Amor”, sobre a protagonista Ana, a narradora informa:

Todo o seu desejo vagamente artístico encaminhara-se há muito no sentido de tornar os dias mais realizados e belos; com o tempo seu gosto pelo decorativo se desenvolvera e suplantara a íntima desordem. Parecia ter descoberto que tudo era passível de aperfeiçoamento, a cada coisa se emprestaria uma aparência harmoniosa; a vida podia ser feita pela mão do homem" (LF, p.24. Grifo nosso).

Arrumar é suplantar a íntima desordem e Ana dedica-se às tarefas domésticas dispensando excessivo cuidado à hora "perigosa da tarde, quando a casa estava vazia sem precisar mais dela, o sol alto, cada membro da família distribuído em suas funções" 
(LF, p.24). A protagonista de "Devaneio e embriaguez duma rapariga" ao contrário de encaminhar seu desejo artístico no sentido de tornar os dias mais belos, entrega-se à íntima desordem, sem medo de estar sozinha consigo mesma.

Com relação aos tempos verbais, observamos que antes de narrar a saída de sábado à noite, prevalece, principalmente, o pretérito perfeito do indicativo, que indica ação começada e terminada no passado, concluída antes de se falar dela. Na narrativa da saída de sábado, verificamos a incidência do pretérito imperfeito do indicativo, que indica uma ação contínua no passado, ou ação simultânea, como podemos observar neste exemplo: "Palestrava, e ouvia com curiosidade o que ela mesma estava a responder..." (LF, p.15). Há uma atmosfera de sonho decorrente da situação em que a personagem se encontra no instante da enunciação: com mal-estar e rememorando um sábado à noite diferente de sua vida diária.

O estado físico inicial da personagem, sugerido pelo marido como uma possível doença, não é explicado na narrativa. Seu calor, sua tontura, revelando um mal-estar físico ("Mas nas fraquezas do primeiro instante parecia doída e delicada no quarto que rodava, que rodava até ela conseguir às apalpadelas deitar-se de novo à cama...”) (LF, p. 13), não contrastam com a sensação que vem a ter de vida sonora e aumentada, depois da narrativa da saída de sábado à noite ("Foi nesse instante que ficou surda: faltou-lhe um sentido. Enviou à orelha uma tapona de mão espalmada, o que só fez entornar mais o caldo: pois encheu-lhe o ouvido de um rumor de elevador, a vida de repente sonora e aumentada nos menores movimento") (LF, p.19). Observamos, portanto, o mal-estar físico da protagonista do início ao final do texto.

Em relação às personagens do conto, a rapariga assume o centro da narrativa e as demais personagens parecem gravitar ao redor dela: o marido, o negociante rico, a mulher de chapéu, os filhos. Destes todos, os filhos, que não se encontram no raio de alcance da visão da rapariga, são referidos três vezes no texto: na primeira, a narradora informa que "Já que os filhos estavam na quinta das titias em Jacarepaguá, ela aproveitou para amanhecer esquisita..." (LF, p.12); a próxima, ocorre no segundo dia em que a personagem permanece na cama, após observação do marido de que ela pode estar doente: "Ela aceitou surpreendida, lisonjeada. Durante o dia inteiro ficou-se na cama, a ouvir a casa tão silenciosa sem o bulício dos miúdos...” (LF, p.13); e a última vez, no final da narrativa, quando arrola elementos da sua vida familiar como o ruído do elevador, o ronco do marido e os filhos no quarto ao lado: "Havia certas cousas boas porque eram quase nauseantes: o ruído como de elevador no sangue, enquanto o marido 
roncava ao lado, os filhos gorditos empilhados no quarto a dormirem, os desgraçadinhos" (LF, p.19).

A maior parte da narrativa se concentra na saída de sábado à noite. A narradora mergulha na consciência da personagem e narra as sensações e pensamentos que ela teve enquanto se embriagava. Narra a dificuldade para alcançar o paliteiro e a sensação de corpo crescido. As mesmas inflexões de voz reaparecem em passagens como "Ai que esquisita que estava. No sábado à noite a alma diária perdida, e que bom perdêla ..." (LF, p.15).

No texto "A explicação inútil", a respeito do conto "Devaneio e embriaguez duma rapariga", Clarice Lispector escreveu:

De "Devaneio e embriaguez duma rapariga" sei que me diverti tanto que foi mesmo um prazer escrever. Enquanto durou o trabalho, estive sempre de bom humor diferente do diário e, apesar de os outros não chegarem a notar, eu falava à moda portuguesa, fazendo, ao que me parece, experiência de linguagem. Foi ótimo escrever sobre a portuguesa (LE, p.173-4).

Estas palavras da autora apontam para uma identidade entre o seu estado de espírito enquanto escrevia o conto e o estado de espírito da personagem portuguesa. A escritora com um "humor diferente do diário" e a personagem "com a alma diária perdida". Mais uma vez insistimos na diferença entre a protagonista de "Devaneio e embriaguez duma rapariga" e Ana, protagonista do conto "Amor", no sentido de que esta se concentra nos afazeres domésticos como um trabalhador braçal. A narradora do conto "Amor" informa que: "o vento batendo nas cortinas que ela mesma cortara lembrava-lhe que se quisesse podia parar e enxugar a testa, olhando o horizonte. Como um lavrador" (LF, p.23). Permanece a distância entre narradora e personagem, e nisso também "Amor" se difere do conto "Devaneio e embriaguez duma rapariga", em que a identidade entre narradora e personagem, como já dissemos, é freqüente.

Em "Devaneio e embriaguez duma rapariga", a atmosfera do conto é a do devaneio, num livre vôo do pensamento, como o vôo de um pardalzito que passasse pela janela e fosse para o Minho. Nessa improvisação, a rapariga deixa transparecer o seu talento para as coisas d'arte em face de sua realidade de dona-de-casa, esposa e mãe, porém, não sem antes a narrativa apontar para a auto-referência da linguagem quase como um aviso ao leitor: "quem encontrou buscou". A frase nos faz pensar na 
famosa opinião de Picasso de que, na pintura, é mais importante encontrar do que pesquisar: "Em minha opinião, a pesquisa nada significa em pintura. Encontrar, eis a questão" $"$ 33.

Roland Barthes (2003, p.337) escreve nas suas anotações de aulas e seminários no Collége de France, 1977 - 1978, publicadas com o título O neutro, sobre a abolição do tempo no sonho que "uma coisa conhecida do sonho é que ele contrai o tempo". O crítico nos chama a atenção para a observação de que o sonho, podendo ter a duração de um relâmpago, não impede que toda uma cena se complete, um panorama do tempo pode se passar na mente de quem sonha.

A saída de sábado à noite apresenta-se inserida em uma atmosfera onírica que pode ser verificada nas passagens destacadas abaixo, pois encerram referências ao sono da personagem e a uma espécie de sonho no qual a personagem observa a si mesma:

E esta gargalhada? Essa gargalhada que lhe estava a sair misteriosamente duma garganta cheia e branca, em resposta à finura do negociante, gargalhada vinda da profundeza daquele sono, e da profundeza daquela segurança de quem tem um corpo. Sua carne alva estava doce como uma lagosta, as pernas duma lagosta viva a se mexer devagar no ar. E aquela vontade de se sentir mal para aprofundar a doçura bem ruim. E aquela maldadezita de quem tem um corpo.

$[\ldots]$

Palestrava, e ouvia com curiosidade o que ela mesma estava a responder ao negociante abastado que, em boa hora, os convidara e pagava-lhes o pasto. Ouvia intrigada e deslumbrada o que ela mesma estava a responder: o que dissesse nesse estado valeria para o futuro em augúrio - já agora ela não era lagosta, era um signo duro: escorpião. Pois nascera em novembro.

$[\ldots]$

Um holofote enquanto se dorme que percorre a madrugada - tal era sua embriaguez errando lenta pelas alturas (LF, p.15-6.Grifo nosso).

O sono profundo, a personagem se vendo na cena, as imagens do corpo em transformação e o holofote que percorre a madrugada enquanto se dorme (invertido para "um holofote enquanto se dorme que percorre a madrugada") configuram uma narrativa

\footnotetext{
${ }^{33}$ (PICASSO Apud CHIPP, 1988, p.266).
} 
marcada pela atmosfera de sonho e vigília, sem realçar a certeza do acontecimento (a saída de sábado à noite) inusitado na vida da jovem dona-de-casa.

Sobre a figuração do espaço moderno, Francastel (1990, p.231), como vimos, escreveu que "deixa de ser uma descrição pitoresca e decorativa para se tornar um registro de gestos ou de ações elementares e de sensações experimentadas no plano da consciência, em função do acordo entre os diferentes sentidos". Nesse sentido, a narrativa clariciana expõe o acontecimento - a saída de sábado à noite - mas de um modo tal que a enunciação, ao lado do registro das sensações, passa a ser tão ou mais importante que o acontecimento. Narrar de um ponto de vista de quem se localiza acima da cena, observando-a, e embaralhando a sintaxe da frase, desvia a atenção do enunciado para a enunciação. E a enunciação segue uma estrutura que não é estranha ao devaneio.

O limite entre realidade e sonho é estreitado no texto. Um paralelo entre o modo de narrar e o modo de pintar da pintura moderna pode ser discutido a partir das seguintes observações de De Micheli sobre o objetivo da pintura surrealista:

Subverter as relações das coisas, contribuindo, dessa maneira, na medida do possível, para precipitar aquela crise de consciência geral que é o objetivo primeiro do surrealismo. Mas, ao lado disso, a pintura surrealista tende também a um outro resultado: à criação de um mundo em que o homem encontre $\mathrm{o}$ maravilhoso, um reino do espírito onde ele se liberte de toda a gravidade e inibição, de todo complexo, atingindo uma liberdade inigualável, incondicionada. O novo e o desconhecido que Baudelaire, fugindo do tédio de uma realidade alienada e desgastada, buscava em seu Voyage, reaparece portanto no maravilhoso surrealista convalidados por uma consagração definitiva. Nesse maravilhoso nos é concedida uma antecipação daquela liberdade total que se coloca na perspectiva da fusão do sonho com a realidade ou da realidade com o sonho, fusão que devolverá aos homens, afinal, a sua integridade (DE MICHELI, 2002, p. 159-60).

O termo maravilhoso não tem o sentido de fantástico, pois se trata, como De Micheli colocou, de um reino do espírito onde prevalece a liberdade, para nós, semelhante ao conceito de iluminação profana de Walter Benjamin. No conto, esta liberdade permite à personagem ver-se de um modo que não se viu antes, estranhar-se, 
posto que se sente experimentando uma nova percepção de si e do mundo. Seu devaneio é uma embriaguez da alma. A personagem é uma "iluminada mais profana", no sentido que Walter Benjamin empregou esta expressão ao observar que

o homem que lê, que pensa, que espera, que se dedica à flânerie, pertence, do mesmo modo que o fumador de ópio, o sonhador e o ébrio, à galeria dos iluminados. E são iluminados mais profanos. Para não falar da mais terrível de todas as drogas - nós mesmos - que tomamos quando estamos sós (BENJAMIN, 1994, p.33).

Não é à toa que esta personagem, ao fim da narrativa, se volta para a lua, alta no céu, o que nos faz pensar em uma iluminação e ao mesmo tempo na expressão popular usada para designar aquilo que fazem os que sonham alto, "andar no mundo da lua" pois, na narrativa, "A lua alta e amarela a deslisar ( a deslisar...Alta, alta. A lua.” (LF, p.20) parece aludir à própria personagem, sozinha, voando em pensamento.

Um outro modo de falar dessa percepção do "eu" pode ser encontrado na concepção do "olhar visionário”, proposta por José Miguel Wisnik (1988, p.284): "uma experiência que resulta do apagamento da visão habitual (o excesso que acompanha a falta de visão comum), que fala por enigmas".

$\mathrm{Na}$ narrativa do que se passou no restaurante sábado à noite não há diálogos, os personagens são descritos com poucos traços e do ponto de vista da protagonista. Podemos propor um esquema de caracterização das personagens no qual teremos: marido versus negociante; protagonista versus mulher de chapéu. $\mathrm{O}$ marido é descrito como um bobo, pois não fala, não bebe, em oposição ao negociante rico, que "cantava de galo" e é associado à figura do diabo (“o mafarrico"); a protagonista, esposa, mãe, sem chapéu, com brio e gorda opõe-se à que ela imagina mulher solteira, sem filhos, e que ela vê com um rico chapéu e magra, "a santarrona". A imagem do negociante rico face ao marido humilha este aos olhos da esposa tornando-o "uma tal piada"; e a imagem da mulher de rico chapéu, face à protagonista, humilha esta, que reage colérica se sobrepondo à humilhação apegando-se aos valores da instituição familiar - o casamento e a maternidade: "...loira como um escudo falso, toda santarrona e fina! - vai ver que nem casada era, e a ostentar aquele ar de santa"/ "E a santarrona toda vaidosa de 
seu chapéu, toda modesta de sua cintura fina, vai ver que não era capaz de parir-lhe, ao seu homem, um filho" (LF, p.17).

Algumas vezes, a narradora menciona a cólera da personagem: logo no início ("Mas colérica fechou-se dura como um leque") (LF, p.11); após o marido tentar um carinho mais eficaz na despedida e sugerir que ela estava doente ("Sua cólera era tênue, ardente") (LF, p. 13); após se sentir humilhada por estar sem chapéu face à outra mulher de rico chapéu ("Na sua sagrada cólera, estendeu com dificuldade a mão e tomou um palito") (LF, p. 17); no final, ao ameaçar fazer faxina na casa (“a casa havia de ver! Ameaçou ela colérica") (LF, p.20).

Em O neutro, Roland Barthes (2003, p.150) observa que para falarmos da cólera “a palavra mais interessante, se lhe restituirmos o modo de ser grego (e não o francês) é to páthos = aquilo que se sente, em oposição ao que se faz; e também por oposição a he páthe: estado passivo" (2003, p.150). O autor esclarece: "he páthos: no neutro: ao mesmo tempo ativo e afetado: afastado do querer-agir mas não da "paixão". A cólera, para Barthes, é um exemplo de estado forte de páthos marcado do qual ele conhece três versões:

1. Como fuga: remetendo-se à teoria das emoções de Sartre, observa este estado como "uma espécie de desfalecimento, uma perda de consciência, portanto, de responsabilidade, no excesso" (2003, p.151). Neste estado, o autor ressalta "a cólera como patema (to páthema: aqueles acontecimentos que nos afetam)" (p.152).

2. Como higiene: observa "o excesso de raiva como uma sangria que faz bem" e cita os Ensaios Morais de Bacon, onde se lê: "Querer abafar em si a semente da cólera não passa de fanfarronada de estóico". Barthes expõe a idéia da cólera útil: “controlar a aparência do descontrole, teatralizar a cólera como elemento de prova de força e, sobretudo, saber dar-lhe fim: sabedoria editada pela escrita (citada por Bacon): 'Encolerizar-se, mas sem pecar, que o sol não se punha sobre vossa cólera'” (p.152).

3. Como fogo: remete-nos à concepção mística e cosmogônica de Boehme, observando que "Boehme, a respeito do mundo e de Deus (como pai colérico), emprega freqüentemente as palavras gru, guim-mig" (2003, p.153). Estas palavras, lemos em nota de rodapé do livro de Barthes, são adjetivos que em alemão significam "ruim, mau, penoso" e "furioso, terrível, horrível". Este estado da cólera é apresentado como um desejo, um ardor irritado e inquieto, algo próximo do furor e da ira: "donde a ira de Deus como fogo que cai sobre os homens" (p.153). 
$\mathrm{Na}$ narrativa, a cólera é teatralizada como prova de força sobre aquilo que incomoda a personagem, conseguindo dar-lhe fim.

O conto ironiza o casamento como status social útil para firmar uma posição privilegiada para a mulher. Notamos que narradora e protagonista recorrem ao casamento como argumento que depõe a favor do caráter da mulher casada em face do que lhe perturba: a sedução de um homem que não é o seu marido e a liberdade da mulher solteira. $\mathrm{O}$ casamento parece se resumir a um laço que tem essa utilidade. Não se trata de um laço sentimental entre esposa e marido. No diálogo entre o casal, ressaltase a falta de comunicação entre marido e esposa, pois ele a beija, ela se esquiva, ele insiste, ela se irrita, a cena termina com o marido atribuindo este comportamento a algum problema de saúde da mulher. O amor é sonhado fora desta relação, pois em uma das fantasias da personagem, a narradora nos informa: "Ela ainda à cama, tranqüila, improvisada. Ela amava ... Estava previamente a amar o homem que um dia ela ia amar. Quem sabe lá, isso às vezes acontecia, e sem culpas nem danos para nenhum dos dois..." (LF, p.13. Grifo nosso). A tranqüilidade com que a mulher casada pensa no surgimento de um novo amor, no entanto, aponta para as transformações sociais pelas quais passou e tem passado a instituição familiar na sociedade moderna.

Para descrevermos o distanciamento entre o casal, poderíamos usar as palavras de Auerbach (2004, p.438) para o casal Charles e Emma Bovary ${ }^{34}$ do romance de Flaubert, ao destacar que "cada um deles está de tal modo encasulado no seu próprio mundo, ela no desespero e nos vagos sonhos desejosos, ele na sua tola satisfação provinciana, que os dois estão totalmente solitários".

Embora possamos identificar no conto de Clarice Lispector e no romance de Flaubert o tema do distanciamento entre os cônjuges, o modo de tratá-lo é muito diferente entre os dois autores.

Em uma passagem do romance de Flaubert, Charles Bovary está humilhado por ter fracassado na operação da perna do jovem Hippolyte e Emma Bovary encontra-se arrependida de ter acreditado que o marido pudesse "valoir quelque chose". Na cena reproduzida abaixo, o marido tenta beijar a esposa, mas ela se esquiva; diz que a ama, mas ela o deixa sozinho. Ele entende, então, que ela talvez esteja doente:

\footnotetext{
${ }^{34}$ Em carta de 06 de fevereiro de 1944 enviada de Belém para Lúcio Cardoso, Clarice Lispector comenta que releu Madame Bovary, tendo aproveitado a cena da morte para "chorar todas as dores que eu tive e as que eu não tive".
} 
Alors, par tendresse subite et découragement, Charles se tourna vers sa femme en lui disant:

- Embrasse-moi donc, ma bonne!

- Laisse-moi! fit-elle, toute rouge de colère.

- Qu'as-tu? qu'as-tu? répétait-il stupéfait. Calme-toi, reprends-toi! Tu sais bien que je t'aime!... viens!

- Assez! s'écria-t-elle d'un air terrible.

Et, s'échappant de la salle, Emma ferma la porte si fort, que le baromètre bondit de la muraille et s'écrasa par terre.

Charles s'affaissa dans son fauteuil, bouleversé, cherchant ce qu'elle pouvait avoir, imaginant une maladie nerveuse, pleurant, et sentant vaguement circuler autour de lui quelque chose de funeste et d'incompréhensible (FLAUBERT, 1936, p.495).

Em Clarice e Flaubert, os sentimentos das personagens femininas em relação aos respectivos maridos se assemelham. Porém, o modo como o sentimento é apresentado por cada autor faz toda a diferença entre suas obras. Como observou Auerbach, no romance de Flaubert, a personagem Emma depende do narrador. Em uma cena de jantar entre o casal Bovary, Auerbach destacou que a narrativa apresenta Emma Bovary em primeiro lugar e, através dela, a situação, sem que se trate da simples reprodução da consciência da personagem, como nas narrativas de primeira pessoa, daí, "embora seja dela que se irradie o quadro, ela própria não deixa de ser uma parte do quadro, situandose em seu centro". Para este estudioso da literatura, a personagem Emma certamente tem a sensação descrita na narrativa, neste caso, a insatisfação com a vida enfadonha, mas não é capaz de exprimi-la, e "se quisesse exprimi-la, não o faria desta forma; para chegar a esta formulação faltam-lhe a agudeza e a fria honestidade que resultam de uma prestação de contas consigo mesma". Não sendo a existência do autor que se apresenta nas palavras, e sim a de Emma Bovary, Auerbach ressalta:

Flaubert não faz senão tornar lingüisticamente maduro o material que ela oferece, em sua plena subjetividade. Se Emma pudesse fazê-lo sozinha, não mais seria o que é, ter-se-ia emancipado de si mesma e, com isso, estaria salva. Assim, ela não vê simplesmente, mas é ela própria vista como alguém que vê e, através disto, 
pela mera designação nítida da sua existência subjetiva, a partir das suas próprias sensações, é julgada (AUERBACH, 2004, p.434).

Na narrativa clariciana não há aquilo que Auerbach destaca em Flaubert como "a mão ordenadora do escritor, que compendia de forma fechada a confusão do conteúdo interno e o dirige no sentido em que ele próprio avança: na direção 'repugnância diante de Charles Bovary"” (p.434). Em Clarice Lispector, a desordem das sensações e dos sentimentos é significativa para a própria estruturação da narrativa, não temos, como em Flaubert, o autor cujo "papel limita-se a escolher os acontecimentos e a traduzi-los em linguagem", com a

convicção de que qualquer acontecimento, se for possível exprimi-lo limpa e integralmente, interpretaria inteiramente a si próprio e os seres humanos que dele participassem; muito melhor e mais inteiramente do que o poderia fazer qualquer opinião ou juízo que lhe fosse apresentado. Sobre esta convicção, isto é, sobre a profunda confiança na verdade da linguagem empregada com responsabilidade, honestidade e esmero, repousa a arte de Flaubert (Ibid., p.435).

O conto de Clarice Lispector recupera o acontecimento, não a partir da precisão da linguagem que o reconstitui, mas da sensação que ele teve para a personagem, daí a narrativa se estruturar como uma espécie de devaneio. A personagem, por isso mesmo, não é julgada pela narradora, podendo amar "sem culpas nem danos para nenhum dos dois".

Flaubert publica seu romance em 1856, Clarice publica seu conto em 1960. Muito tempo os separa, mas as mudanças com relação à emancipação da mulher na sociedade tardaram a chegar. Em relação à cidadania no Brasil, apenas na constituição de 1946 foi conferido à mulher o direito e a obrigação de votar; e em relação à família, na mesma constituição, como informa Boris Fausto (2006, p.401), após longos e acalorados debates entre partidários e adversários do divórcio, "prevaleceu afinal a pressão da Igreja Católica e a opinião dos demais conservadores. Ficou definido que a família se constituía pelo casamento de vínculo indissolúvel”. A legalização do divórcio no Brasil só ocorreu em 1977, porém, em Portugal, como destaca Cecília Barreira (2004), além do divórcio, o Código Civil de 1910, aprovado sob o governo republicano de Afonso 
Costa, permitia que a mulher administrasse os seus próprios bens e publicasse sem autorização do marido as obras de sua autoria.

Pensando que, na narrativa, é pela imaginação que a protagonista liberta-se da cólera, observamos que as situações narradas se resumem em: estabelecer uma conversa interessante com seu duplo; imaginar-se amando alguém que ela ainda não ama; lembrar-se da noite de sábado, quando teve assunto para falar com outro homem, beber, sorrir, perceber a beleza de um quadro e, até mesmo, observar o marido como "uma tal piada".

Mesmo encontrando explicação para a postura humilde do marido diante do negociante riso, é com riso e desprezo que o observa durante o sábado à noite:

E se o marido não estava borracho é que não queria faltar ao respeito ao negociante, e, cheio d'empenho e d'humildade, deixava-lhe, ao outro, o cantar de galo. O que assentava bem para a ocasião fina, mas lhe punha, a ela, uma dessas vontade de rir!, um desses desprezos! Olhava o marido metido no fato novo e achava-lhe uma tal piada! Borrachona a mais não poder mas sem perder o brio de rapariga. E o vinho verde a esvaziar-se-lhe do copo (LF, p.14. Grifo nosso).

O retorno ao quarto da rapariga, espaço do início da narrativa, ocorre como um salto que exclui o deslocamento do restaurante à sua casa, como ocorreu quando saltou da casa ao restaurante:

Na sua sagrada cólera, estendeu com dificuldade a mão e tomou um palito.

Mas finalmente a dificuldade de chegar em casa desapareceu: remexia-se agora dentro da realidade familiar de seu quarto, agora sentada no bordo da cama com a chinela a se balançar no pé (LF, p.17).

Esta passagem contribui para reforçar nossa observação de que a saída de sábado é um acontecimento recuperado em devaneio pela personagem, que, sentada "no bordo de sua cama com a chinela a balançar o pé", encontra-se "conformada e cética":

E, como entrefechara os olhos toldados, tudo ficou de carne, o pé da cama de carne, a janela de carne, na cadeira o fato de carne que o marido jogara, e tudo quase doía. E ela cada vez maior, vacilante, túmida, gigantesca. Se conseguisse 
chegar mais perto de si mesma, ver-se-ia ainda maior. Cada braço seu poderia ser percorrido por uma pessoa, na ignorância de que se tratava de um braço, e em cada olho podia-se-lhe mergulhar dentro e nadar sem saber que era um olho. E ao redor tudo a doer um pouco. As coisas feitas de carne com nevralgia. Fora o friozito que tomara ao sair da casa de pasto.

Estava sentada à cama, conformada, cética (LF, p. 18).

Gaston Bachelard (1996, p.144), ao abordar a diferença entre sonho e devaneio considera, principalmente, a presença do cogito no segundo, pois "o devaneio é uma atividade onírica na qual subsiste uma clareza de consciência”. Interessa-nos sua observação de que o sonhador está imerso no devaneio, sem que o espaço de imersão seja um mediador plástico, pois, como escreveu,

parece que no mundo intermediário, onde se confundem devaneio e realidade, ele realiza para si uma plasticidade do homem e do mundo sem que nunca se tenha necessidade de saber onde está o princípio dessa dupla maleabilidade. Esse caráter do devaneio é tão verdadeiro que se pode dizer, inversamente: onde existe maleabilidade existe devaneio (BACHELARD, 1996, p.161-2).

Consideramos esta passagem do estudo de Bachelard importante para frisarmos o caráter de devaneio que acompanha toda a narrativa, pois temos a presença do cogito do sonhador, e a maleabilidade, principalmente, logo após a personagem abrir os olhos e reconhecer o espaço familiar do quarto, ressaltando que "tudo no fundo estava igual":

Então, já que isso terminaria mesmo por acontecer, tanto se me faz abrir agora mesmo os olhos, o que fez, e tudo ficou menor e mais nítido, embora sem nenhuma dor. Tudo, no fundo, estava igual, só que menor e familiar. Estava sentada bem tesa na sua cama, o estômago tão cheio, absorta, resignada, com a delicadez de quem espera sentado que outro acorde. 'Empanturras-te e eu que pague o pato', disse-se melancólica, a olhar os deditos brancos do pé. Olhava ao redor, paciente, obediente. Ai, palavras, palavras, objetos do quarto alinhados em ordem de palavras, a formarem aquelas frases turvas e maçantes que quem souber ler, lerá. Aborrecimento, aborrecimento, ai que chatura. Que maçada. Enfim, ai de 
mim, seja lá o que Deus quiser. Que é que se havia de fazer. Ai, é uma tal cousa que se me dá que nem bem sei dizer (LF, p.18).

Esta passagem aponta para as palavras como objetos do quarto a serem lidos por quem souber ler, o que soa como uma confissão de que a narradora-personagem está a improvisar com palavras a narrativa.

$\mathrm{Na}$ ilustração de Cyro del Nero para o conto observa-se o desenho de móveis do quarto em diferentes pontos de vistas simultaneamente: enquanto a cama e o tapete são desenhados como se fossem visto de cima, duas cadeiras estão desenhadas como se vistas de lado. A ilustração comunica-se com a desordem da narrativa, no sentido de que o texto não segue uma seqüência causal, embaralhando a localização do acontecimento de sábado à noite em relação ao momento inicial do conto em que a personagem, em seu quarto, encontra-se sozinha em casa.

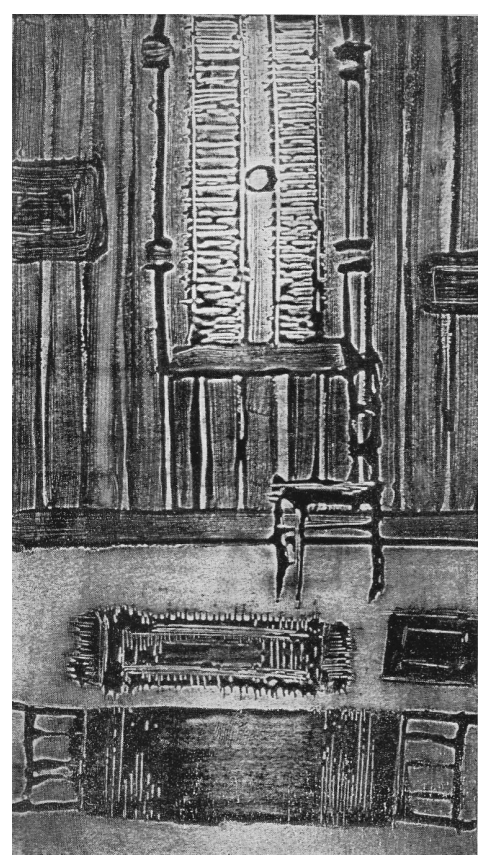

Do ponto de vista da carnavalização, estudada por Mikhail Bakhtin (2002, p.8), a embriaguez de sábado à noite se compara ao "triunfo de uma espécie de libertação temporária da verdade dominante e do regime vigente de abolição provisória de todas as relações hierárquicas, privilégios, regras, tabus". Observando que se trata de um momento em que a personagem encontrava-se com "a alma diária perdida", propomos que, semelhantemente ao carnaval, a narrativa desse instante soa como um triunfo para a personagem que está em seu quarto devaneando em torno do experimentado no 
sábado à noite, colocando-se como a protagonista de si mesma em uma história na qual ela, ao lado do marido, teve a liberdade de falar, beber e rir com outro homem e pensar grosserias, triunfante no mundo em que pôde expressar-se, e agora rememora em devaneio, vendo-se dentro da cena e permitindo-nos vê-la também de fora dela como narradora. Neste instante, nos damos conta do desdobramento do sujeito em dois, e do quanto o sujeito, estranhando, deslumbra-se com o outro que é ele mesmo.

$\mathrm{Na}$ narrativa, prevalece o repouso, que se estende até o final quando a personagem, já de olhos abertos, parece comprometer-se a recuperar a alma diária perdida: “Amanhã não, porque não estaria lá muito bem das pernas. Mas depois de amanhã aquela sua casa havia de ver: dar-lhe-ia um esfregaço com água e sabão que lhe arrancariam as sujidades todas! A casa havia de ver" (FL, p.20). Observamos, portanto, o adiamento do retorno às tarefas do lar, ao cotidiano, protelado para depois de amanhã, e, se observarmos um pouco mais, não apenas protelado, mas tornado hipotético, pois os verbos "dar-lhe-ia" e "arrancariam" estão no futuro do pretérito, tempo que indica a ocorrência de um fato futuro, mas em relação a um fato passado, como pudemos notar em relação à narrativa do acontecimento de sábado à noite - um futuro rememorado.

Para que possamos discutir em que sentido esta personagem dona-de-casa, mãe e esposa, é também uma mulher dotada para as coisas d'arte, devemos observar que, enquanto estava no restaurante, a rapariga, ao visualizar um quadro que nos lembra uma natureza-morta, refere-se à sua "sensibilidade artística" do seguinte modo:

Mas que sensibilidade! Mas que sensibilidade! Quando olhava o quadro tão bem pintado do restaurante ficava logo com sensibilidade artística. Ninguém lhe tiraria cá das idéias que nascera mesmo para outras cousas. Ela fora pelas obras d'arte. Mas que sensibilidade! Agora não apenas por causa do quadro de uvas e pêras e peixe morto brilhando nas escamas (LF, p.16).

Mayer Schapiro (1996, p.59-61), autor de um importante ensaio sobre o significado da natureza-morta na pintura de Cézanne, considerou que os objetos escolhidos para esse tipo de pintura pertencem a campos de valores específicos: "o privado, o doméstico, o gustatório, o convival, o artístico, a vocação e o hobby, o decorativo e suntuoso e, menos freqüentemente, num clima negativo, objetos oferecidos à meditação como símbolo da vaidade, lembrança do efêmero e da morte”, e que 
muitas vezes associados a um estilo que explora paciente e minuciosamente a aparência de coisas corriqueiras - suas texturas, luzes, reflexos e sombras -, os objetos da natureza-morta trazem à consciência a complexidade do fenomenal e da sutil inter-relação da percepção com o artifício da representação (SCHAPIRO, 1996, p.61).

Pelo aspecto kitsch da descrição que a personagem faz da natureza-morta, a portuguesa se mostra visivelmente desejosa de se passar por uma pessoa sensível para as coisas d'arte. A natureza-morta, no entanto, nos faz pensar, mais uma vez, no trocadilho presente no texto: "quem encontrou, buscou", agora acrescido de outra: "quem souber ler, lerá", pois consideramos que uma leitura atenta às imagens elaboradas pela narradora-personagem deste conto pode nos levar a perceber como a sensibilidade artística da personagem aparece no escritura do texto, não no sentido de uma sensibilidade vulgar, mas sim de uma sensibilidade que encontra seu paralelo na obra dos pintores modernos.

No primeiro parágrafo, a referência às imagens fragmentadas de partes do corpo da personagem, olhos, seios, braços, nos fazem pensar em um quadro de Pablo Picasso chamado "Nu arrumando o cabelo" 35 .

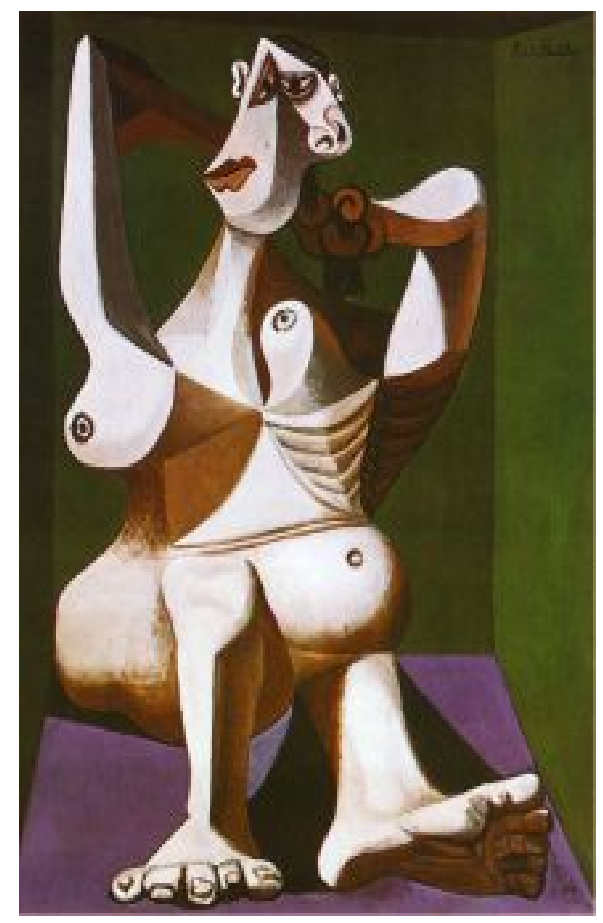

\footnotetext{
35 Pablo Picasso, Woman Dressing Her Hair (1940), Museum of Modern Art, New York.
} 
A comparação que propomos entre a passagem inicial do conto - a que apresenta a personagem penteando-se de frente para o espelho - e este quadro não pretende dizer que a narradora-personagem repetiu com palavras a pintura de Picasso, mas que ela nos deixa ver uma imagem que se assemelha à mulher da pintura de Picasso. Esta imagem se constitui a partir do nosso trabalho de leitor, pois não há uma descrição do corpo, as imagens são referidas de modo descontínuo, deixando a nós leitores o trabalho de tentar obter um todo a partir dos fragmentos:

Estava a pentear-se vagarosamente diante da penteadeira de três espelhos, os braços brancos e fortes arrepiavam-se à frescurazita da tarde. Os olhos não se abandonavam, os espelhos vibravam ora escuros ora luminosos. Cá fora, duma janela mais alta, caiu à rua uma coisa pesada e fofa. Se os miúdos e o marido estivessem à casa, já lhe viria à idéia que seria descuido deles. Os olhos não se despregavam da imagem, o pente trabalhava meditativo, o roupão aberto deixava aparecerem nos espelhos os seios entrecortados de várias raparigas (LF, p.11 Grifo nosso).

Em Je suis lê cahier - Os cadernos de Picasso, coordenado por Arnold e Marc Glimcher (1986, p.141), há uma passagem escrita por Sam Hunter para o caderno de desenho de número 110, 1946, onde lemos que no mês de março, em Paris, Picasso “enchera um caderno com desenhos para seu quadro grande de 1949, Mulher arrumando os cabelos (que Zervos publicou em 1948, sob o título Carnet de dessins de Picasso). Em seguida, o autor acrescenta:

Três meses depois, enquanto as tropas alemães entravam em Paris e Pétain se preparava para assinar um armistício, Picasso estava trabalhando em Royan para concluir um quadro vigoroso e um tanto sombrio, que renovava as invenções fantásticas de seu período de monumentos e banhistas de Dinard, mas no contexto de uma fisionomia concreta, caracterizada de forma um tanto brusca, de Dora Maar, sobre um tronco nu brutalmente esquartejado. $\mathrm{O}$ nu rígido é apresentado num espaço raso, repartido, parecendo uma caixa, pintado em lúgubres tons de cinza e púrpura profundos, um espaço de proscênio estranhamente reminiscente 
das últimas jaulas pungentes e vazia de Francis Bacon, aprisionando massas ainda mais fantásticas e alucinatórias de carne humana lívida. A imagem rígida mais compulsiva de Picasso em Mulher arrumando o cabelo é uma estranha mistura híbrida de ânimos de solene compostura e imensa dignidade (a pose um tanto formal de estudo de vida) com o monstruoso (as cruéis distorções e a anatomia desorganizada) (HUNTER, 1986, p.141-2).

A citação, embora longa, ajuda-nos a entender por que Hunter considerou que, no quadro de Picasso, há "uma aproximação da vida e da morte, de impulsos civilizados e destrutivos", relacionados à guerra e à presença alemã. Há também "uma comédia nãointencional, mas mesmo assim endossada, no tema da vaidade da toalete feminina, tão grosseiramente caracterizada numa protagonista tão sombria” (p.144).

O segundo parágrafo do conto, introduzido pelo grito do jornaleiro, termina com a seguinte frase: "mas, colérica, fechou-se dura como um legue". Mais uma vez, lembramo-nos de quadro de Pablo Picasso: "Mulher com leque"36.

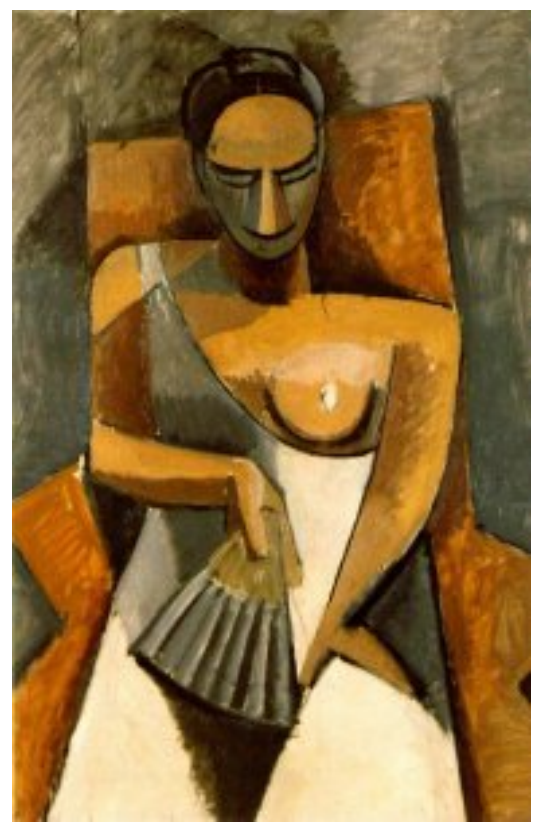

No conto, a narradora compara o movimento da personagem ao do leque. Processo semelhante podemos verificar na pintura de Picasso com relação ao desenho da figura feminina rígida, com a cabeça verticalmente inclinada para baixo, permitindonos ter uma visão do traçado do nariz, sobrancelhas, olhos, decote do vestido, queixo e

\footnotetext{
${ }^{36}$ Pablo Picasso, Woman with a fan ( 1908), Hermitage Museum, St. Petersburg, Russia.
} 
seio assemelhando-se à linha curva do leque aberto segurado em posição vertical pela mão da mulher sentada.

Na segunda parte de A Legião estrangeira (1964), o pequeno texto "Verão na sala" retoma esta cena da mulher com leque:

\footnotetext{
"Verão na sala"

Com o leque ela pensa alguma coisa. Ela pensa o leque e com o leque se abana. E com o leque fecha de súbito o pensamento num estalido, vazia, sorridente, rígida, ausente. O leque distraído e aberto no peito. "A vida é mesmo engraçada", concorda ela como visita que é recebida na sala de visitas. Mas num alvoroço controlado, eis que se abana de súbito com mil asas de pardal (LF, p.161).
}

O texto é uma cena breve que, como o quadro de Picasso e a passagem do conto que estamos analisando, apresenta a figura de uma só personagem feminina com um leque na mão. Neste pequeno texto reencontramos o pardal que no conto aparece na cantiga entoada pela personagem um pouco antes de fechar-se colérica: "quem viu o pardalzito ... passou pela janela ... voou pr'além do Minho! - mas, colérica, fechou-se dura como um leque" (LF, p.11). A intertextualidade explícita pode ser observada na recorrência da personagem com o objeto que segura, o leque, porém, considerando também a intertextualidade implícita, observamos nas três situações o tema da mulher sozinha e o leque como objeto que encerra analogia com o movimento de seu corpo. No conto, essa comparação é explicitada na frase "fechou-se dura como um leque"; no quadro, a figura central feminina, sentada, tomando quase todo o espaço da pintura, mantém um movimento de inclinação vertical que indica uma atitude reflexiva e, ao mesmo tempo, de isolamento, a analogia com o leque se dá, por exemplo, pelos traços do desenho do corpo feminino comparado à curva do leque mantido aberto e imóvel; no texto "Verão na sala", a personagem feminina, referida apenas pelo pronome pessoal de terceira pessoa "ela", confunde-se com o leque na passagem em que fechar o leque coincide com fechar o pensamento: "E com o leque fecha de súbito o pensamento num estalido, vazia, sorridente, rígida, ausente". Nas três situações, o figurativo faz pensar por meio do movimento, do gesto.

Mayer Schapiro (1996, p.175), no capítulo "Mulher com leque de Picasso: sobre transformação e autotransformação", texto que aborda as mudanças realizadas pelo pintor ao passar do desenho original para a pintura de "Mulher com leque" (1905), um 
outro quadro de Picasso que apresenta uma mulher com um leque, mas desta vez a figura feminina estando de perfil, destaca que "em obras posteriores, variações da postura da Mulher com leque reaparecem em outros contextos e sugerem a duradoura importância desse conceito como imagem-raiz do artista”. O crítico está interessado em analisar as variações das posturas rígidas em quadros do pintor.

Em Clarice Lispector, as variações da imagem da mulher com leque na mão são significativas. No conto, inicialmente, a jovem mulher casada fecha-se, colérica, dura como um leque. Posteriormente, irá abanar-se com "um jornal a farfalhar no quarto" e a narrativa, pelo mergulho no interior da personagem nos dará o registro de seus pensamentos e sensações. No texto "Verão na sala", a mulher com leque, vista do exterior apenas, é objeto visível carregado de subjetividade a cargo da imaginação do leitor.

No texto "O casamento e a família", a professora portuguesa Cecília Barreira (2004, p.19), ao descrever como se processava o namoro e o casamento no século XIX, destaca os diferentes "códigos" de conduta usados pelos jovens na comunicação não verbal. O leque era um dos objetos usados na linguagem dos amantes, permitindo-se falar, como para as flores, em uma linguagem dos leques:

O leque na sua ambigüidade - apesar dos tratados que ministravam judiciosamente o seu manuseamento - era o lugar da imaginação, da emoção, símbolo absoluto do corpo ausente e dissimulado. A voz não se tornava necessária porque era o gesto do símbolo que se comunicava (BARREIRA, 2004, p.19).

Citando Bernardo de Alcobaça, "autor de uma curiosa Enciclopédia do amor", a autora destaca que até o movimento que se lhe imprime pode denunciar o estado social:

Nas mãos de uma viúva o precioso objeto move-se lenta e compassadamente, como convém 'àquela que chora'. Nas mãos das solteironas o leque agita-se com uma rapidez violenta fruto da ansiedade com que cobiçam um casamento. Nas mãos das mulheres casadas deve ondular com serenidade, num suave contentamento. As raparigas casadoiras agitam-no febrilmente, excitadas, sinal por excelência de conquista (Idem.). 
O pequeno texto "Verão na sala" foi publicado em 04 de março de 1972, no Jornal do Brasil, com o título "Verão no baile". Na nova versão, no lugar do pronome "ela", encontra-se: "a gorda matrona"; no lugar de "rígida": "rígida pela cintura apertada"; e no lugar de "a vida é mesmo engraçada": "Também sei, elas arranjarão casamento". No novo texto, a personagem, uma gorda matrona, diferente da personagem anterior, revela seu pensamento.

Em outra passagem do conto, a narradora-personagem "desenha" na parede a imagem trêmula de uma guitarra a partir da analogia de uma parte deste instrumento, as cordas, com as linhas formadas pelas frestas do sol com a sombra das lâminas de uma persiana. Esta construção imaginosa nos reporta a duas observações: a primeira, sobre a pintura moderna, presente no Dicionário da pintura moderna (1981) no qual lemos que entre a escolha significativa e muito restrita dos temas da pintura de vários cubistas estão os instrumentos musicais; e a segunda, sobre a explicitação da relação entre narrativa e pintura em Água viva (1976, p.13-4), obra onde se lê: “Aprofundo as palavras como se pintasse, mais do que um objeto, a sua sombra". A analogia com a pintura não está, portanto, em uma espécie de ekphrasis, mas na observação de que a narradora de Água viva, como muitos pintores modernos, deseja antes a alusão do que a representação. A narradora de "Devaneio e embriaguez duma rapariga" também "pintou" a sombra do acontecimento de sábado à noite.

Outras imagens referidas na narrativa, como a da metamorfose da lagosta em escorpião, ambas relacionadas ao corpo da personagem, nos fazem pensar em algumas palavras que André Breton escreveu em seu "Manifesto do Surrealismo" (1924) a respeito da imagem surrealista. No nosso entender, são palavras que encerram idéias que se assemelham às de outras vanguardas européias no que tange à construção de imagens na arte moderna do início do século XX. Vejamos:

Os inumeráveis tipos de imagens surrealistas lembrariam uma classificação que, por hoje, não me proponho tentar. Agrupá-las de acordo com suas afinidades especiais levar-me-ia longe demais; quero levar em conta essencialmente sua virtude comum. Para mim, a mais forte é a que apresenta o grau de arbitrariedade mais elevado, não o escondo; a que se leva mais tempo a traduzir em linguagem prática, seja porque ela encerra uma dose enorme de contradição aparente, seja porque um de seus termos é dela curiosamente privado, seja porque, anunciandose sensacional, ela tem o aspecto de se desprender tenuemente (porque ela fecha 
bruscamente o ângulo de seu compasso), seja porque ela tira de si mesma uma justificação formal irrisória, seja porque ela seja de ordem alucinatória, seja porque ela se presta muito naturalmente ao abstrato, mascara-o de concreto, ou inversamente, seja porque ela implica na negação de alguma propriedade física elementar, seja porque desencadeia o riso (Apud Teles, 1987, p. 201-2).

No conto, a arbitrariedade em compor analogias entre o corpo da protagonista e algumas imagens pode ser verificada, de modo explícito, na seguinte passagem: “já agora não era uma lagosta, era um duro signo: escorpião. Pois que nascera em novembro". Em uma passagem do seu manifesto André Breton escreve: "Eis 'os elefantes com cabeça de mulher e leões alados', eis o 'peixe solúvel', que ainda me assusta. PEIXE SOLÚVEL, não sou eu o peixe solúvel, nasci sob o signo de Peixes e o homem é solúvel em seu pensamento! A fauna e a flora do surrealismo são inestimáveis" (Ibid., p.203).

A palavra "rapariga" em língua portuguesa tem como significado o sentido de mulher jovem, mas, no Brasil, em especial no nordeste e algumas outras regiões, significa, de acordo com o Dicionário Houaiss da língua portuguesa (2001), "mulher que vive com um homem"; “mulher que vive da prostituição", "meretriz”. Em Portugal, a palavra pode ter o sentido de "moça do campo, roceira".

O conto opera com diferentes sentidos da palavra "rapariga", sem fixá-los. Ao final, quando lemos: "Então a grosseria explodiu-se em súbito amor: cadela, disse a rir". A palavra "cadela", de acordo com o referido dicionário, em sentido figurado, significa "mulher pouco digna, de baixa condição social ou de comportamento ou hábitos reprováveis". É uma grosseria, para Mikhail Bakhtin, um gênero verbal particular da linguagem familiar, mas, uma vez que a narradora diz para si mesma sorrindo, o seu riso, diferente do riso carnavalizado, é uma espécie de sarcasmo, pois, como observa Regina Pontieri (2001, p.151), “sem dúvida, Clarice figura situações de vida pequenoburguesas tratadas de modo irônico, do qual o riso franco passa longe. Sua visão se enraíza numa subjetividade que, mesmo aspirando fortemente à fusão com o mundo, é também consciência individual". A palavra cadela assemelha-se à palavra galinha e esta, como destacou Ligia Chiappini (1998), é usada para significar mulher da rua, mulher fácil, mulher de muitos homens. É nesse sentido que Chiappini considera o conto "Uma galinha" uma "espécie de fábula irônica" em que a fuga da galinha assemelha-se aos momentos em que as mulheres dos contos claricianos saem à rua e 
"quase viram um galo prestes a anunciar um novo mundo possível e uma nova possibilidade de ser dentro dele" ${ }^{37}$. Na narrativa de "Devaneio e embriaguez duma rapariga" a sensibilidade artística da protagonista permite-lhe uma das melhores fugas: a da alma diária perdida. Como ela mesma declara: "Que bom perdê-la".

\section{A legião estrangeira (1964)}

Em 1964, ano do golpe militar no Brasil, duas importantes obras de Clarice Lispector foram publicadas, A legião estrangeira e A paixão segundo G.H., pela Editora do Autor, fundada por Fernando Sabino, Rubem Braga e Walter Costa. Arnaldo Franco Junior (1999, p.150), comentando a respeito de A legião estrangeira, destacou que a própria autora, em depoimento ao MIS, declarou que esta obra "ficou no depósito porque ninguém prestou atenção nela, foi inteiramente abafada pela Paixão". Quando ocorreu o depoimento ao MIS, ainda não tinha sido lançada uma segunda edição desta obra, Clarice Lispector informou: "Agora nessa segunda edição, a Ática quer publicar só os contos e depois as anotações...." (OE, p.148).

De acordo com Nádia Gotlib (1995, p.315), a partir de 1962, após alterações na revista Senhor, Clarice passou a assinar a coluna "Children's corner”, da seção "Sr. \& Cia.”, “em que publica tanto contos mais curtos, como 'A quinta história', contos mais longos, como 'Os desastres de Sofia', quanto crônicas, como 'Mineirinho' e 'Brasília: cinco dias', além de fragmentos variados". Todos esses textos fazem parte da primeira edição de $A$ legião estrangeira, com capa de Maria Roberto, contendo duas partes, uma composta de treze contos e a outra, sob o título "Fundo de gaveta", composta de textos de gêneros diversos (crônicas, contos, depoimentos) e introduzida pela seguinte nota da autora:

Esta segunda parte se chamará, como uma vez me sugeriu o nunca assaz citado Otto Lara Resende, de "Fundo de Gaveta". Mas por que livrar-se do que se amontoa, como em todas as casas, no fundo das gavetas? Vide Manuel Bandeira: para que ela me encontre com "a casa limpa, a mesa posta, com cada coisa em seu lugar". Por que tirar do fundo da gaveta, por exemplo, "a pecadora queimada", escrita apenas por diversão enquanto eu esperava o nascimento de meu primeiro filho? Porque o que presta também não presta. Além do mais, o que obviamente

\footnotetext{
${ }^{37}$ CHIAPPINI, Ligia. "Mulheres, galinhas e mendigos: Clarice Lispector, contos em confronto". Revista Mulheres e Literatura. Ano 2, Vol.2, 1998. Site:

http://www.letras.ufrj.br/litcult/revista_mulheres/index.php.
} 
não presta sempre me interessou muito. Gosto de um modo carinhoso do inacabado, do malfeito, daquilo que desajeitadamente tenta um pequeno vôo e cai sem graça no chão (LE, p.127).

As palavras usadas pela autora para apresentar o "Fundo de gaveta" sugerem que esta segunda parte reúne textos inacabados, o que está correto, desde que "inacabado" perca qualquer sentido pejorativo, pois, como já foi discutido em relação ao texto "Escrever, humildade, técnica", que também faz parte desta segunda parte da obra que estamos tratando, inacabada é a própria percepção que temos do mundo, e se o artista é consciente deste fato, sua expressão fiel a esta percepção pertence ao mundo dos possíveis da arte moderna. Inacabado e malfeito, nesta nota, estão relacionados carinhosamente à figura de algo vivo, um pinto, aprendendo a voar.

Sobre esta segunda parte da obra, Gotlib (1995), observando que, para Clarice Lispector, os fragmentos do "Fundo de gaveta" são simples 'anotações', ressaltou:

dentro dessa categoria, tão aberta, quase tudo é permitido: contos, crônicas, provérbios, máximas, aforismos, reportagens, ficção científica, crítica de pintura, de escultura, de dança, de música, crítica de seus próprios textos, lendas, retratos de personagens, descrição de lugares - reais ou fictícios? - e fragmentos que traduzem sobretudo uma poética - da escrita e da leitura (GOTLIB, 1995, p.354).

Muitos textos do "Fundo de gaveta" abordam reflexões sobre as artes, merecendo, por isso, ser lidos à luz da produção artística brasileira e das teorias e críticas sobre a arte moderna, pois assim, quem sabe, poderemos aprofundar o conhecimento do modo como a autora compreendeu as artes plásticas de seu tempo e aproximarmo-nos com maior intimidade das possíveis relações entre literatura e outras artes em sua poética.

Sobre a produção artística da década de 1960, Paulo Reis (2006, p.12), após observar que os mais diversos autores (Hans Magnus Enzensberger, Hal Foster, Marília Andrés Ribeiro, Augusto de Campos e Otília Arantes) “definiram também como vanguarda as manifestações artísticas ocorridas a partir de final dos anos 50 e início dos 60", considerou que as manifestações do concretismo na poesia e nas artes visuais, o tachismo, a poesia 'beat' ou o expressionismo abstrato, sendo distintas das vanguardas históricas, possuíam em comum uma de suas idéias fundamentais: a de serem uma renovação da linguagem artística. No Brasil, de forma explícita, o conceito e o termo 
vanguarda eram largamente utilizados pelos artistas e críticos "em clara reiteração da particularidade da produção daquele momento". Como exemplo, Reis cita títulos de artigos de Hélio Oiticica, Frederico Morais, Mário Barata, Roberto Schwarz e Ferreira Gullar.

Como informam Teresa Montero e Lícia Manzo (2005, p.93), “em 1963, Clarice Lispector foi convidada a proferir uma palestra sobre a vanguarda na literatura brasileira, no XI Congresso Bienal do Instituto Internacional de Literatura IberoAmericana, realizado de 29 a 31 de agosto, na Universidade do Texas". O texto, intitulado "Literatura de vanguarda no Brasil", posteriormente, lido pela autora em outros lugares, Vitória, Belo Horizonte, Campos, Belém do Pará e Brasília, em 1974, encontra-se no volume Outros escritos e nos chama atenção de imediato o fato de logo no início a autora ressaltar que nem sempre o ficcionista está à altura de falar até sobre ficção ou "sabe estabelecer suas relações com as outras artes, a fim de poder dar uma idéia de um todo orgânico, cujas raízes são diversas e nem sempre imediatamente visíveis" (OE, p.95).

Uma definição de vanguarda é dada pela autora depois de explicar o modo como entende o fundo-forma, a coisa propriamente dita, uma união entre o que foi vislumbrado e o que foi produzido por meio da linguagem: "seria, pois, um novo ponto de vista - mesmo que às vezes levasse apenas a mais um milímetro de visão. O novo modo de ver leva fatalmente a uma mudança formal - e agora estou, para melhor clarificação, usando a dicotomia de fundo e forma" (OE, p.105). Ver, porém, não é uma ação passiva para a autora. Reportando-se à literatura de Guimarães Rosa como vanguarda, ela observa: "Somos, por enquanto, falsos cosmopolitas, e o interior do Brasil revelado por Guimarães Rosa está em cada um de nós, e tão bem revelado que atinge a altura de uma invenção. Descobrir é inventar, ver é inventar” (OE, p.107).

Quase no final de sua palestra, a autora, informando que "talvez de agora em diante não mais escreva", fala de sua pintura: “O que me 'descontrai', por incrível que pareça é pintar, e não ser pintura de forma alguma, e sem aprender nenhuma técnica. Pinto mal que dá gosto e não mostro meus, entre aspas, 'quadros' a ninguém [...]". Sabemos que a autora começou a pintar nos anos 1970, esta passagem possivelmente foi acrescentada à palestra inicial.

Nas duas obras publicadas em 1964, A legião estrangeira e A paixão segundo G.H., percebe-se forte presença das artes plásticas. Na segunda parte de A legião estrangeira, no "Fundo de gaveta" há textos sobre arte e literatura; e em A paixão 
segundo G.H., a protagonista, uma escultora, expõe suas preocupações com a forma e reflete sobre a influência da escultura em seu modo de lidar com a linguagem:

Quanto à minha chamada vida íntima, talvez também tenha sido a escultura esporádica o que lhe deu um leve tom de pré-climax - talvez por causa do uso de um certo tipo de atenção a que mesmo a arte diletante obriga. Ou por ter passado pela experiência de desgastar pacientemente a matéria até gradativamente encontrar sua escultura imanente; ou por ter tido, através ainda da escultura, a objetividade forçada de lidar com aquilo que já não era eu" (PSGH, p.30).

No referido depoimento ao MIS, após o comentário de Clarice Lispector de que na segunda edição de A legião estrangeira os contos seriam separado das "anotações", recebendo o título Para não esquecer, Affonso Romano de Sant'Anna perguntou-lhe se iria anexar outros textos aos do "Fundo de gaveta", acrescentando:

Porque quem quiser compreender melhor a possível teoria que você estivesse fazendo sobre a sua própria arte de escrever encontraria nesses textos uma série se elementos. Eles comentam a sua maneira de ver o mundo e a sua maneira de escrever. Um volume desse, assim, separado, seria muito útil para estudantes e para a crítica em geral (OE, p.149).

A editora Ática publicou sob o título A legião estrangeira (1977) apenas os treze contos da primeira parte e sob, o título Para não esquecer (1978), outros textos que pertenciam ao "Fundo de gaveta".

\section{"Fundo de gaveta"}

Há uma passagem na Teoria da literatura de Wellek e Warren (1955) na qual lemos que as teorias próprias dos poetas sobre a pintura e suas preferências quanto a certos pintores são aspectos que podem ser estudados e relacionados com suas teorias e gostos literários. De acordo com os autores, estudos dessa natureza são um largo campo de investigação apenas parcialmente percorrido nas últimas décadas.

Sabemos que a primeira edição da Teoria da literatura é de 1948 e que atualmente muitos estudos adotando o viés comparativo proposto por Wellek e Warren já foram realizados, especialmente sobre obras de escritores franceses como Stéphane 
Mallarmé e Marcel Proust, porém, o mesmo não pode ser dito da obra de Clarice Lispector e, por isso, consideramos que falta, em sua fortuna crítica, um estudo detido sobre os textos do "Fundo de gaveta" que abordam questões sobre as artes. Não podemos deixar, por outro lado, de observar que esses textos da escritora não são textos teóricos, mas, literatura, pois, como escreveu Roland Barthes (1996, p.19), ao abordar a primeira das três forças da literatura (Mathesis, Mimesis, Semiosis), seus textos “encenam a linguagem, em vez de, simplesmente, utilizá-la"; "engendram o saber no rolamento da reflexividade infinita"; e, neles, "o saber reflete incessantemente sobre o saber, segundo um discurso que não é mais epistemológico mas dramático".

\section{"Gastão Manoel Henrique"}

O primeiro texto do "Fundo de Gaveta" tem como título o nome do artista plástico Gastão Manoel Henrique, nascido em Amparo-SP, em 1933. De acordo com Celso Favaretto (1997, p.134), o artista freqüentou "por três anos o curso de pintura da Escola Nacional de Belas-Artes, viajando em seguida para a Europa, onde permaneceu até 1963”. Trabalhou na oficina que executava silkscreens para Arp, Vasarelli e Herban e, de volta ao Brasil, fixou-se no Rio de Janeiro e, posteriormente, em Brasília, de 1968 a 1972, quando retornou a São Paulo. Lecionou no Instituto de Artes e Arquitetura da UNB, na Escola de Artes Visuais do Parque Lage, no Museu de Arte Moderna do Rio de Janeiro e no Instituto de Artes da Universidade de Campinas.

$\mathrm{O}$ artista esteve presente nas principais exposições de arte ocorridas no Brasil entre os anos 1960 e $1970^{38}$, marcados pela proliferação das galerias de arte em nosso país. Entre os prêmios recebidos, Walmir Ayala (1986, 389), em seu Dicionário de pintores brasileiros, cita: "1963 - Isenção de Júri, Salão de Arte Moderna, Rio de Janeiro; 1966 - $1^{\circ}$ prêmio de escultura; 1967 - Prêmio V Resumo de Arte, Jornal do Brasil, Rio de Janeiro (RJ); $1^{\circ}$ prêmio de Concurso Caixas, Petite Galerie, Rio de Janeiro (RJ)".

Em Arte no Brasil, no capítulo dedicado aos artistas contemporâneos, assinado por José Roberto Teixeira Leite, Pedro Manuel e Carlos Eduardo Silveira Matos, os autores observam que, nos anos 1950, surgiu no cenário das artes plásticas brasileiras a terceira geração de artistas modernos, “cujas características se consolidaram no final

\footnotetext{
${ }^{38}$ A lista das exposições individuais e coletivas de Gastão Manoel Henrique nesse intervalo de tempo pode ser observada, por exemplo, no Dicionário de pintores brasileiros, de Walmir Ayala.
} 
dessa década e princípios da seguinte". Sobre a época dessa geração preparada pela atuação das gerações de 1930 e 1940, escreveram:

Distingue-se pela participação ativa do público e pelo intenso intercâmbio internacional. As correntes européias são amplamente veiculadas e discutidas, contando com as principais tendências - às vezes rebatizadas ou alteradas - com representantes entre nós. Obras do mundo inteiro chegam ao Brasil, sobretudo graças à Bienal de São Paulo, e criações dos nossos artistas comparecem, com maior freqüência, aos grandes centros internacionais. Surgem galerias que expõem e comerciam no sistema de consignação. Os maiores jornais do país dedicam espaço a uma seção sobre artes plásticas (LEITE et al, 1979, p.903).

A escrever sobre Gastão Manoel Henrique, os autores ressaltaram: "partiu de um aprendizado acadêmico, mas bem cedo se preocupou com o suporte da pintura, que desde 1963 era tão importante quanto as cores” (p.913).

Paulo Sérgio Duarte (1998, p.24), observando que foi a partir da I Bienal de São Paulo que se acelerou "o processo de intercâmbio de artistas e do público brasileiro com a produção internacional", considerou que o ambiente que antecede a arte nos anos 1960 é marcado pelo "sucesso das correntes abstratas informais, e particularmente do construtivismo". Como ressaltou, "é nesta época que se inscrevem, a partir do Rio de Janeiro e de São Paulo, as primeiras experiências francamente construtivas da arte brasileira".

No Dicionário das artes plásticas no Brasil, Roberto Pontual (1969), ao abordar o trabalho de Gastão Manoel Henrique, recorre às palavras de Clarice Lispector:

A seu respeito disse Clarice Lispector, em 1964: "Pois é pintura tocável: as mãos também a olham. Gastão Manoel Henrique cria o material antes de pintá-lo, e a madeira torna-se tão imprescindível para a sua pintura como o seria para um escultor de madeira. E o material criado é religioso: tem o peso de vigas de convento. É compacto fechado como uma porta fechada. Mas nele foram esfoladas aberturas, rasgadas quase com unhas. E é através dessas brechas que se vê o que está dentro de uma síntese. Cor coagulada, violência, martírio são as vigas que sustentam o silêncio de uma simetria religiosa" (PONTUAL, 1969, p. 263). 
Clarice ressaltava a importância da madeira e da cor, enfatizando do aspecto construtivo da pintura. A citação é uma passagem do texto "Gastão Manoel Henrique", possivelmente, escrito para o catálogo da exposição do artista realizada em 1963, pois, no livro Arte/Brasil/Hoje: 50 anos depois, Roberto Pontual (1973, p.167) voltou a escrever sobre Gastão Manoel Henrique e arrolou na bibliografia a seguinte referência: "LISPECTOR, Clarice. Apresentação no catálogo da individual na Galeria Seta, $1963^{\prime \prime 39}$.

Sobre a obra de Gastão Manoel, Pontual, neste seu livro de 1973, observou que a pesquisa matérica determinou o trabalho do artista, "a ponto de situar sua pintura dos primeiros tempos não como resultante da imposição exclusiva de tintas sobre suportes planos passivos, mas como diálogo necessário e evidenciado entre estas e o próprio suporte, assim transferido da condição de matéria-prima para a de significante" (p.167). Realizando um balanço do que Gastão tinha produzido nos últimos dez anos, ressaltou:

O fato é que, ao longo de quase dez anos, toda a obra de Gastão vem se estruturando com e através da madeira, numa linguagem que parece nunca ter desejado a figuração explícita, para colocar-se mais ao nível da criação de signos, às vezes destinados a referir, obliquamente, o real exterior a cada pintura, montagem ou objeto por ele produzidos. Em paralelo, há que observar, no desenvolvimento dessa obra, a substituição progressiva das superfícies bidimensionais (sempre, na origem, voltado para o espaço explícito das texturas) pelas formas escultóricas estáticas ou móveis, puramente arquitetônicas ou analogicamente paisagísticas (PONTUAL, 1973, p.167).

Sobre a obra de Gastão Manoel, Walmir Ayala (1986), enfatizando a importância do suporte e da cor, também ressalta a materialidade do que foi realizado pelo artista:

a primeira qualidade a ser vista nos trabalhos de Gastão é a da aparência da própria matéria, a qual não está a serviço mecânico de suporte, assim como a tela para as tintas, mas participando do jogo e da composição cromática, emprestando,

\footnotetext{
${ }^{39}$ No catálogo da exposição individual do artista realizada na Galeria Seta, São Paulo, em agosto de 1963, há, na lista de exposições realizadas por Gastão até 1975, referência a esta exposição. Ver: HENRIQUE, Gastão Manoel. Gastão Manoel Henrique. São Paulo: Galeria Arte Global, 1975 (Cópia do Instituto de Estudos Brasileiros - IEB, da USP).
} 
ao mesmo tempo, textura, forma e cor. O artista não usa a madeira crua, desprovida de tratamento; tinge-a, encera-a, às vezes queima-a e ocasionalmente utiliza tintas espessas, opacas; consegue resultado exuberante nos tons verdes, transparentes, associa áreas de densas terras e negras de fumo; abre territórios claros, amarelos e quase brancos e, dramaticamente, dentro de um escavado, faz cintilar um segmento em vermelho lacre. O jogo cromático de Gastão Manuel [sic] Henrique não funciona numa superfície de pintura convencional. Vê-se que suas áreas de cores nascem e morrem com as formas propostas. Em relação à temática, não julgamos proveitoso extrair traduções e identificações de coisas empíricas para os seus inventos (AYALA, 1986, p.388).

A leitura de Clarice Lispector, não sendo tradução, nem propriamente crítica, é uma criação feita a partir da obra de um artista que anos depois passará a produzir supondo justamente a participação ativa do espectador, pois, como destacou Roberto Pontual, citado por Favaretto (1997, p.110), a respeito da série de Objetos Conversíveis: “criados entre 1967 e 1969, em madeira pintada de branco ou enriquecida de cores vivas, supôs inclusive a necessidade de participação direta do espectador no manuseio e reconstrução permanente da obra, segundo um jogo de possibilidades infinitas".

No vídeo "Gastão Manoel Henrique" ${ }^{40}$, direção de Ângela Galrão, o artista fala de seu trabalho para Marco do Valle, comenta sobre a aproximação que manteve com outros artistas plásticos, como Guido Guinard, Lygia Clark e Hélio Oiticica, e sobre a exposição em que quatro trabalhos exatamente iguais, peças grandes em madeira oca, pintadas de branco, que foram dadas a outros artistas para que cada um pintasse a seu modo. Cada um interpretou a forma de sua maneira. Os trabalhos foram expostos na Petit Galerie, Rio de Janeiro.

Para Walter Zanini (1983), autor de História geral da arte no Brasil, entre 1963-64, ocorreram "as primeiras aproximações dos artistas às novas figurações” (p. 734). Rio e São Paulo “assemelhavam-se a outros centros urbanos mundiais e à sociedade de consumo neles gerada, havendo condições para o surgimento, aqui, de uma iconografia oriunda da comunicação de massa". Observando que "as articulações fizeram-se através da estimulação de formas figurativas européias e norte-americanas", ressaltou a importância de “destacar também a presença do ideário construtivo no Brasil

\footnotetext{
${ }^{40}$ GALRÃO, Angel. (dir) Gastão Manoel Henrique. VHS, $25 \mathrm{~min}$. Campinas: TV Universitária Unicamp.
} 
dos anos 50 como um agente de influência na pop local". Detendo-se no "ideário construtivo", observou que "artistas mais jovens persistiram no cultivo de linguagens geometrizantes e construtivas (ligadas ao contexto internacional)". Entre esses artistas, citou Gastão Manoel Henrique:

$\mathrm{Na}$ produção de outros artistas despontaram diferenciadas buscas geométricas emocionais ou as que conservam sensações da realidade objetiva, a exemplo de Gastão Manoel Henrique, paulista fixado no Rio, interessado numa de suas fases a de objetos "conversíveis" - na participação ativa do espectador (ZANINI, 1983, p.763).

Paulo Reis (2006, p.43-4), observando que "o contexto social político nacional do início dos anos 60 viu surgir uma produção artística ligada conceitualmente aos anos 50, ao mesmo tempo em que carregada da ansiedade própria do momento em que se vivia", considerou que a propalada volta à figuração foi menos um contraponto à abstração "e mais uma tentativa de absorver criticamente a Arte Pop e afirmar um partido frente à realidade nacional. Os artistas protagonizaram um rico episódio de embate com a realidade imediata através da tradição construtiva, da Arte Pop e do novo realismo". Um excelente documento para perceber esse aspecto da arte brasileira dos anos 1960 é o texto de Hélio Oiticica, "Esquema geral da nova objetividade", originalmente publicado no catálogo da mostra "Nova objetividade brasileira", realizada no Museu de Arte Moderna do Rio de Janeiro, em 1967.

No texto de Clarice Lispector, observa-se um enunciador que se defronta com algo construído pelo artista. Sem descrever o que vê, cita elementos que nos fazem pensar em uma estrutura visível: formas e cores. O enunciador elogia a simetria do artista: "Em Gastão Manuel Henrique a surpresa de ver que ele começa por não receiar [sic] inclusive a simetria [..] A simetria de Gastão Manuel Henrique é concentrada, conseguida, mas não dogmática" (LE, p.128). Um dos elementos valorizados pela arte clássica, a simetria, não é descrita, apenas percebida pelo enunciador. A linguagem não dá certezas do que está vendo: "não é propriamente tranqüilidade o que está ali”. Em alguns instantes, parece que o enunciador estabelece uma conversa consigo mesmo: "São altares? Pelo menos o silêncio de altar. O silêncio de portais". Suas palavras apenas sugerem os elementos figurativos (simetria, cruz, altar, portais, igreja, muros, portas, esverdeamento, intensidade de crepúsculo, bronze velho nas cores quietas, cor 
coagulada). É como se este observador dividisse conosco o modo como vê o que Gastão Manoel Henrique construiu, percebendo silêncio de coisa sagrada e, ao mesmo tempo, uma violência latente:

E o material criado é religioso como uma porta fechada. Mas nele foram esfoladas aberturas, rasgadas quase por unhas. E é através dessa brechas [sic] que se vê o que está dentro de uma síntese. Cor coagulada, violência, martírio são as vigas que sustentam o silêncio de uma simetria religiosa (LE, p.129).

A linguagem do enunciador não parece querer reproduzir o objeto, mas aludir ao percebido. É pela observação da cor que associa a pintura a algo intermediário entre vida e morte: "o esverdeamento toma um tom do que estivesse entre vida e morte, uma intensidade de crepúsculo". Quando enuncia que "em nenhum quadro está dito: igreja”, refletimos que também o texto não é demonstrativo da pintura de Gastão Manoel Henrique. O texto, igualmente, não traduz o visível da pintura. $\mathrm{O}$ aspecto religioso parece ser apenas sentido pelo enunciador.

Diferente do homem criticado por Kandinsky, habituado a ver na pintura imitação da natureza, a natureza através do temperamento do artista, um simples estado de alma, anatomia, perspectiva, um ambiente, o enunciador clariciano destaca na materialidade da pintura as sensações que cores e formas lhe sugerem, pois para ele "tudo é tocável, finalmente tocável para quem chega de longe. Pois é pintura tocável: as mãos também a olham". Seu texto parece querer justamente expressar o modo como sente a obra.

O texto "Gastão Manoel Henrique" aparece em uma passagem da obra Água viva (1973), com alterações importantes. O início dos dois textos pode ser comparado abaixo:

Em Gastão Manoel Henrique a surpresa de ver que ele começa por não receiar inclusive a simetria. É preciso experiência ou coragem para revalorizá-la, quando facilmente se pode imitar o "falso assimétrico", uma das originalidades mais comuns (LE, p.128).

Foi assim que vi o portal da igreja que pintei. Você discutiu o excesso de simetria. Deixa eu te explicar: a simetria foi a coisa mais conseguida que fiz. Perdi o medo da simetria, depois da desordem da inspiração. É preciso experiência ou coragem 
para revalorizar a simetria, quando facilmente se pode imitar o falso assimétrico, uma das originalidades mais comuns (AV, p.69).

No novo texto, Gastão Manoel Henrique é suprimido, e em seu lugar está a narradora-pintora assumindo-se como artista, declarando que viu o portal da igreja que pintou.

Na passagem abaixo, extraída do texto "Gastão Manoel Henrique", observamos que o corroído que é percebido na pintura de Gastão assemelha-se ao inacabado de que a escritora se referiu na apresentação do "Fundo de gaveta":

Há uma luta de coisa que apesar de corroída se mantém de pé, e nas cores mais densas, há uma lividez daquilo que mesmo torto está de pé (LE, p.128)

Esta passagem encontra-se modificada da seguinte forma na obra Água viva:

Há uma dura luta pela coisa que apesar de corroída se mantém de pé. E nas cores mais densas há uma lividez daquilo que mesmo torto está de pé (AV, p.69-70. Grifo nosso).

Na nova versão de Água viva, a palavra "luta" é alterada de dois modos: primeiro, qualificando-a por meio do acréscimo do adjetivo ("dura"); segundo, substituindo a locução adjetiva que tem função de adjunto adnominal (“de coisa”) e é restritivo por um complemento nominal ("pela coisa"), que completa o sentido do substantivo "luta". No primeiro texto, a ênfase recaía sobre a "coisa", a obra, compreensível, pois era Clarice Lispector escrevendo sobre a pintura de Gastão Manoel Henrique. No segundo, a ênfase está na luta, parte ativa da sentença. Ressalta-se, portanto, o trabalho para se conseguir realizar a "coisa que apesar de corroída está de pé", a obra que a narradora-pintora está construindo com palavras.

Além de outras alterações, em Água viva, a passagem "E é através dessas brechas que se vê o que está dentro de uma síntese" sofre o seguinte acréscimo: "E é através dessas brechas que se vê o que está dentro de uma síntese, dentro de uma simetria utópica" (Grifo nosso). Trata-se de um acréscimo importante, visto que o texto começa e termina ressaltando a simetria sentida na obra: concentrada, conseguida, nãodogmática, hesitante, religiosa. 
Em artigo originalmente publicado em Les Temps Modernes, em 1963, Pierre Francastel (1993) realizou uma análise dos aspectos sociais da simetria do século XV ao XX e destacou que na medida em que a simetria exprime um estado estável do universo,

era fatal que uma arte fundada sobre a simetria correspondesse aliás ao período da história na qual o homem fez o inventário de um universo considerado como objetivo, ou melhor, como estável e positivamente estruturado independentemente das regras do espírito (FRANCASTEL, 1993, p.195).

No contexto do final do século XIX e início do século XX, para o autor, "refletindo uma sociedade que não se considera mais como colocada diante de um universo imutável, criada por um demiurgo e que se trata de explorar, mas diante de um mundo em devir que é preciso arrumar", os artistas "empenharam-se em fixar elementos móveis do contínuo que foge da percepção para integrá-los em sistemas abertos e não mais rigorosamente simétricos, isto é, estabilizados, eles se esforçam por aprofundar a experiência do ritmo". O objetivo principal do artista "será a mobilidade em vez do equilíbrio gerador de inércia", o artista se esforçará "por fixar as coisas numa forma que não seja absolutamente livre, pois é determinada, mas permaneça em movimento, aberta sobre a ambigüidade do devir" (p.197-8).

Entre os dois exemplos estudados, Mondrian e Delaunay, Francastel escreveu: "foi Robert Delaunay o primeiro a ter consciência da necessidade não só de exprimir com os meios antigos sensações modernas, mas de elaborar a nova linguagem plástica adaptada às apreensões visuais de seu tempo" (p.199). Explicando-se, observou que

partindo, após os Impressionistas e sobretudo Seurat, da observação do círculo das Cores, Delaunay criou uma representação direta do espaço em movimento. Tendo compreendido o que significava - para além do Simultaneísmo - o caráter vibratório da Cor, apreendeu que ela não constitui um atributo complementar da linha e dos volumes, mas o suporte da percepção ótica sobre a qual se baseia, em última análise, toda arte figurativa [...] (Ibid, p. 1999).

Reportando-se aos textos do pintor, Francastel ressaltou que o próprio Delaunay tornou preciso em "páginas que constituem um dos textos-chave dessa época, o papel da cor como meio de apreensão imediata e total do universo e necessariamente como meio 
de comunicação, apto a exprimir aliás tanto a simetria como a lateralidade" (p.199). Francastel foi organizador da obra Du cubisme à l'art abstrait, Les cahiers inédits de Robert Delaunay, de 1958. Em uma carta do pintor a August Macke, reproduzida nesta obra, Delaunay escreveu: "Muitos dos meus trabalhos são feitos a partir da natureza, 'diante do motivo', como se costuma dizer. Mas o que me parece mais importante é a observação do movimentos das cores". ${ }^{41}$

No capítulo sobre o espaço moderno, vimos que, para Francastel, a pintura abstrata de Delaunay é resultado de uma ordem modificada pela lógica das sensações. A sensação, por sua vez, como disse Francis Bacon, citado por Deleuze: "é o que passa de uma 'ordem' a outra, de um 'nível' a outro, de um ‘domínio' a outro”.

Clarice Lispector, em seu texto, parece aludir às suas sensações ao escrever sobre a pintura moderna de Gastão Manoel. A autora, atenta ao suporte e às cores e suas articulações, constrói um texto que tem em sua estrutura o próprio aspecto fugidio da percepção. Seu texto começou destacando que a simetria praticada pelo artista é de uma nova ordem, mas não a esclarece, e, uma vez que o texto foi, inicialmente, destinado ao catálogo de uma exposição do pintor, deixava ao leitor que pudesse contar com os dois trabalhos (o de Gastão e o de Clarice) a aventura de buscar uma nova síntese no sentido que o texto propunha em relação à obra de Gastão Manoel Henrique, ao ressaltar que a simetria conseguida "é também hesitante, como a dos que passaram pela esperança de que duas assimetrias encontrar-se-ão na simetria. Esta como solução terceira: a síntese”.

\section{"Paul Klee"}

Como no texto anterior, o título deste texto de Clarice Lispector também é o nome de um artista plástico, o pintor suíço Paul Klee, nascido em 1879, em Münchenbuchsee, perto de Berna, e falecido em 1940, em Berna.

Já vimos na introdução deste trabalho que, no catálogo da Exposição de Artistas Brasileiros, realizada no Museu de Arte Moderna do Rio em 1952, Mário Pedrosa identificou entre os nossos artistas mais atuais "a grande filiação dos que provém de Klee, o grande artista que conciliou a poesia e a abstração, o lirismo e a forma, o superrealismo com a transcendência plástica". Pouco tempo depois, em um texto sobre o pintor, intitulado "Klee, o ponto de partida", publicado na Tribuna da imprensa em 1953, Pedrosa ressaltou a importância do pintor para a arte moderna do século XX:

\footnotetext{
${ }^{41}$ CHIPP (1988, p.230).
} 
A arte moderna, depois que destruiu numa geração e meia toda a estética naturalista e impressionista, chegava no início do século a um ponto de partida radical. Klee fez o despojamento metodológico do passado conceitual, a fim de poder pintar, colocar-se sábio, nu e inocente como uma criança, diante do objeto, da coisa sensível, para que ela fale com sua linguagem própria, por si, sem palavras (PEDROSA, 2000, 192).

Günther Regel, no prefácio de uma edição da obra Sobre a arte moderna e outros ensaios, de Paul Klee, ao escrever sobre o artista, dando especial atenção às anotações que ele deixou em seus diários, ressaltou:

Klee era um artista plástico inteiramente dedicado, e não só entendia de outras artes - coisa que raramente acontecia com seus colegas pintores -, como também era um poeta bastante produtivo e, sobretudo, um músico muito ativo. Deixou uma quantidade relativamente grande de epigramas e poemas que, como suas pinturas, giram em torno do tema central da criação. Eles demonstram a 'natureza filosófica' do seu autor, e também que ele dominava com mestria a linguagem expressa em palavras (REGEL, 2001, p.15-5).

Clarice e Maury Gurgel viveram em Berna de 1946 a 1949. Lá está localizado o Centro Paul Klee ${ }^{42}$, inaugurado em 20 de junho de 2005. Neste espaço está reunido o acervo pertencente à Fundação Paul Klee (até então exposto no Museu de Arte de Berna), a coleção particular da família (pertencente a Felix Klee, filho do pintor) e obras de coleções particulares.

Nos depoimentos publicados por Olga Borelli (1981, p.42) sob o título "Clarice Lispector: esboço para um possível retrato", lemos que nos "períodos de grande dinamismo" Clarice planejava viagens e imaginava-se caminhando "delicadamente pelos floridos jardins de Rosegarten, na Suíça, a caminho do museu com obras de Paul Klee...".

O título do texto de Clarice poderia nos indicar que se trata do pintor. Observa-se a referência ao quadro Paysage aux oiseaux jaunes (1923), mas também não é

${ }^{42}$ Ver http://www.paulkleezentrum.ch/ww/de/pub/web_root/zpk.cfm - Site do Centro Paul Klee, disponível nas seguintes línguas: Alemão, Inglês e Francês.

Ver também http://www.swissinfo.org/flash/special/klee_2005/eng/pk.html - Site que permite fazer uma visita interativa ao Centro Paul Klee. 
especificamente do quadro que o texto trata, mas da reflexão que o quadro provoca no enunciador, encerrando a própria linguagem do texto, como em "Gastão Manoel Henrique", uma relação com a pintura destacada.

Carlos Mendes de Sousa (2000, p.288), ao analisar o texto de Clarice Lispector, considerou que "curiosamente o diálogo estabelecido nesse fragmento não vem de uma qualquer aproximação aos aspectos pictóricos da obra de Klee, mas apresenta, a partir de um quadro do pintor, uma reflexão sobre um dado tema decisivo, aliás, na afirmação da poética clariciana: a liberdade".

Em "Paul Klee" a forma encena algo sobre a coragem (de criar formas livres) e a covardia (de aderir às normas da tradição), as frases vacilam no texto, como as figuras no quadro Paysage aux aiseaux jaunes ${ }^{43}$, que não encerram cópias de um real. O título do quadro parece descrevê-lo, no entanto, um olhar para a pintura revela que esta, sem negar o título, escapa da descrição realista que um leitor "agarrado às grades da prisão", para usarmos uma expressão do texto "Paul Klee", esperaria encontrar.

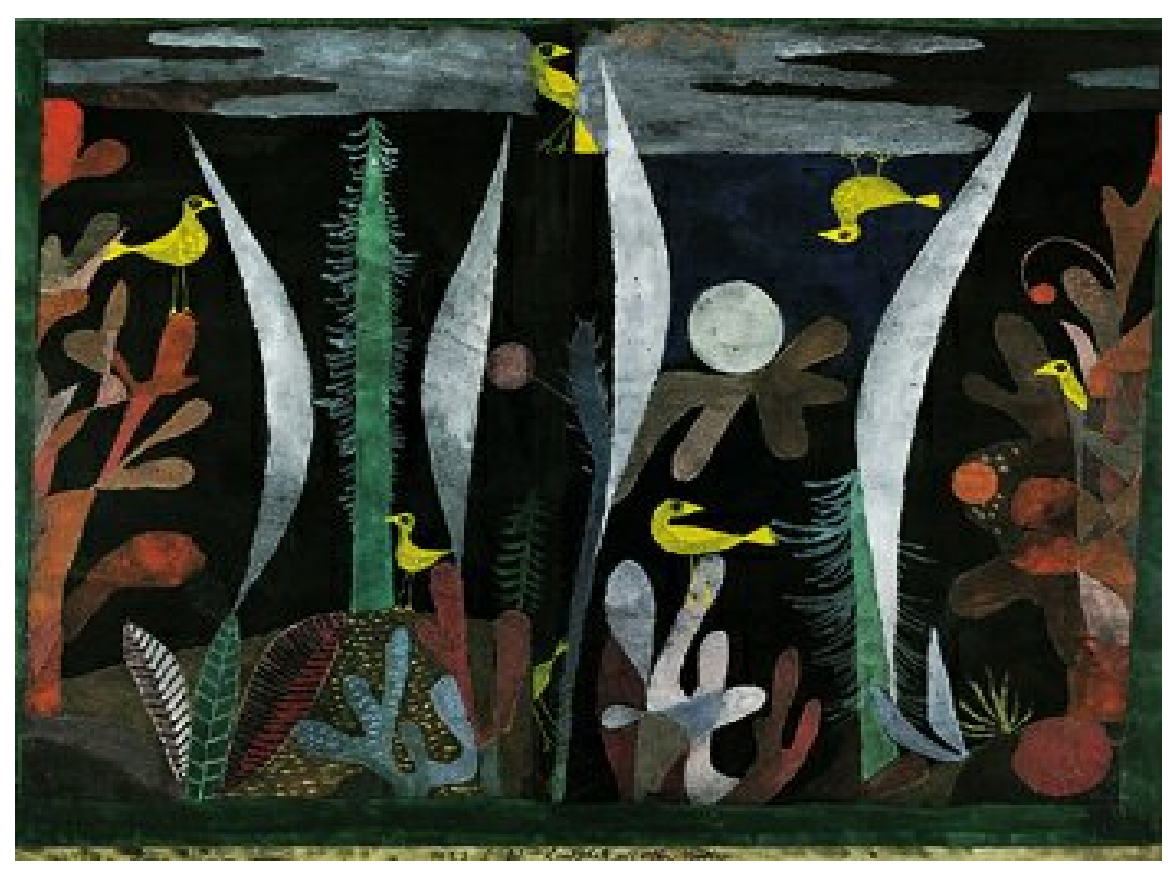

Sobre os quadro de Klee, Günther Regel (2001, p.9) escreveu que "são, no sentido mais autêntico do termo, simplesmente o milagre do processo da criação que se torna visível, e que portanto passa a ser experimentado também pelos outros: a magia do devir das coisas". Sobre os títulos, após ressaltar a capacidade de Klee para "expressar o

\footnotetext{
${ }^{43}$ Paul Klee, Paysage aux aiseaux jaunes (1923). Reproduzido na obra: BOSI, Alfredo. Reflexões sobre a arte. São Paulo: Ática, 2004.
} 
indizível, por meio de recursos oferecidos pela poesia”, considera que esta capacidade se mostra em muitos dos títulos de seus quadros. Inicialmente, ao lermos esta última observação, pensamos nos títulos de Klee como uma tradução do indizível dos quadros. Posteriormente, alertados por João Adolfo Hansen de que a pintura de Klee produz "uma forma que não é redutível ao dizível; assim, o indizível não é fundo que se expressa, mas um efeito relacional, produzido como indizível, da forma" ${ }^{44}$, percebemos que o título mantém com a pintura a "magia do devir das coisas" que a arte moderna de que estamos tratando mantém com o mundo.

Há uma passagem na Filosofia da arte moderna de Herbert Read em que o autor cita palavras de Karl Nierendorf ${ }^{45}$ sobre a visita de Paul Klee à Itália:

Uma experiência inesquecível e profundamente dinâmica foi a visita ao famoso Aquário de Nápoles... Por trás das paredes de vidro numa sala com pouca luz surge todo esse mundo misterioso do oceano, suficientemente perto para as pessoas sentirem a respiração e a vida dessa fauna monstruosa e dessa flora demoníaca e sobrenatural. É fascinante ver uma flor transformar-se em animal e descobrir que uma rocha é uma tartaruga ou um peixe velho coberto de musgo (NIERENDORF, Apud READ, s/d, p.189).

Segundo Nierendorf, citado por Read, quando o pintor regressou da Itália, deixou-se "absorver completamente pela poesia e pela literatura, 'consagrando-se a um estudo intenso de Poe, Baudelaire, Gogol, Dostoievski, E. T. A. Hoffmann, Byron, Voltaire, Aritófanes e o poeta do absurdo e do sinistro, Christian Morgenstern'". Para Read, escritores que

têm algumas características comuns: são simultaneamente profundos e claros, filósofos e trocistas, comicamente macabros. Ao mesmo tempo está presente na maior parte deles um elemento lírico - essa qualidade nem ao autor do Cândido a recusaria. E estas são precisamente as qualidades que Klee viria a expressar em sua pintura (READ, s/d, p.191).

\footnotetext{
${ }^{44}$ Observação do professor Hansen durante o exame de qualificação desta tese.

45 "Notas sobre Klee". In: Paul Klee: paintings. Watercolourd, 1913-1939. Edição de Karl Nierendorf. Oxford University Press. Nova Iorque, 1941.
} 
Em seus Diários, Klee deixou muitas passagens líricas e anotações sobre as leituras que fez, as artes, os lugares que visitou, sua arte, os amigos, alguns acontecimentos vividos, a música

Há uma passagem de Argan (1992, p.323) sobre a obra de Klee que é muito esclarecedora:

Tomada em seu conjunto (um conjunto que é antes um contínuo, de milhares de pequenos quadros a óleo, aquarela, têmpera, e uma infinidade de desenhos, esboços, gravuras), a obra de Klee é uma espécie de diário de sua própria vida interior ou profunda, de tudo o que permaneceu no estágio de impulso ou motivo, e não se traduziu como causa de determinados efeitos, não constituiu história. Nesse sentido, Klee pode ser considerado, na pintura, um paralelo de Joyce; assim como em Joyce as palavras e as frases, em Klee as imagens também se decompõem, se recompõem e se misturam segundo nexos alógicos e assintáticos, mas vitais e sensíveis como ligamentos nervosos (ARGAN, 1992, p.323).

Diante do quadro de Klee, o que nos toca em primeiro lugar é a beleza de um mundo misterioso. A sensação de fundo do mar e, ao mesmo tempo, a sensação de que estamos livres para olhar sem a pressa de encontrar referentes pois eles não existem fora desta pintura figurativa, mas, não narrativa ou ilustrativa. Sem entendermos propriamente o que vemos, ficamos com o mistério que a pintura nos dá a ver. É preciso esquecer alguma lógica rígida que separe de um lado a flora e de outro a fauna. Tem-se a impressão de aquário, um pedaço do mundo marinho reunido ao mundo terrestre, onde os peixes são pássaros entre plantas submersos harmoniosamente. Um mundo perfeitamente possível na imaginação das crianças, que são seres mais libertos do utilitarismo.

Clarice Lispector publicou no Jornal do Brasil, em 1969, o texto "O artista perfeito" ${ }^{46}$ :

Não me lembro bem se é em Les donnés immediates de la conscience que Bergson fala do grande artista que seria aquele que tivesse, não só um, mas todos os sentidos libertos do utilitarismo. O pintor tem mais ou menos liberto o sentido da visão, o músico o sentido da audição (DM, p.228).

\footnotetext{
${ }^{46}$ O mesmo texto foi publicado no Jornal do Brasil em 1973 com novo título "Um ser livre".
} 
Mais à frente, supondo que fosse possível "educar, ou não educar, uma criança, tomando como base a determinação de conservar-lhe os sentidos alertas e puros", pergunta-se: “Seria ela artista pelo simples fato dessa educação?” Para a autora, não:

Essa criança seria artista do momento em que descobrisse que há um símbolo utilitário na coisa pura que nos é dada. Ela faria, no entanto, arte se seguisse o caminho inverso ao dos artistas que não passam por essa impossível educação. Ela unificaria as coisas do mundo não pelo seu lado de maravilhosa gratuidade mas pelo seu lado de utilidade maravilhosa. Ela se libertaria. Se pintasse, é provável que chegasse à seguinte fórmula explicativa da natureza: pintaria um homem comendo o céu. Nós, os utilitários, ainda conseguimos manter o céu fora de nosso alcance. Apesar de Chagall (Idem, p.229).

Imaginando ainda que essa criança, tornada adulta, não fosse artista, "não sentisse necessidade de transformar as coisas para lhes dar uma realidade maior - não sentisse enfim necessidade de arte", seria um inocente. Então, ressalta: "E arte, imagino, não é inocência, é tornar-se inocente". Ao final, supunha: "As exposições de desenhos de crianças, por mais belas, não são propriamente exposições de arte. E é por isso que se as crianças pintam como Picasso, talvez seja mais justo louvar Picasso que as crianças. A criança é inocente. Picasso tornou-se inocente" (DM, p.229).

A confusão entre a arte moderna e os rabiscos infantis ou a pintura dos mentalmente enfermos entra em pauta sempre que o público não consegue discernir o que é fundamental no fenômeno artístico. A esse respeito, em 1947, o crítico Mário Pedrosa (1949, p.143), durante o encerramento da exposição de pintura organizada pelo Centro Psiquiátrico Nacional, sob os auspícios da Associação dos Artistas Brasileiros, em sua conferência "Arte, necessidade vital" ${ }^{47}$, observou que a arte moderna nem sempre foi compreendida pelo público, que não raro identificou os artistas modernos "aos selvagens, aos criminosos, aos loucos, ou apontados simplesmente como mistificadores" (p.148). Para Pedrosa, diante de obras que falam por si mesmas, o público não entende que há um novo conceito de arte, "o qual não era mais do que a redescoberta do sentimento artístico na sua pureza, tão translúcida na obra dos anônimos primitivos". Trata-se, para o crítico, de uma evolução ou revolução de valores

\footnotetext{
${ }^{47}$ Publicada também no Suplemento do Correio da Manhã, em abril de 1947.
} 
"bem expressa por André Lhote ao marcar a diferenciação de atitude do artista moderno em face do impressionista, do renascentista e do primitivo" (p.149).

Observando que a atividade artística não depende de "leis estratificadas, frutos da experiência de apenas uma época na história da evolução da arte", que é uma atividade que se estende a todo ser humano, pois "a vontade de arte se manifesta em qualquer homem de nossa terra" (p.151), Pedrosa reconhecia uma coincidência feliz no modo mais amplo como psicólogos e artistas modernos estavam considerando o fenômeno artístico "em face dessas suas manifestações primárias", mas observava que falta às amostras embrionárias expostas pelo Centro Psiquiátrico Nacional, "matéria bruta emotiva da criação formal”,

aquela terrível vontade quase inumana que vencia o próprio caos interior de Van Gogh, impondo uma organização plástica e disciplinando suas forças explosivas, subordinando tudo à ordem cósmica final necessária à criação.

Mesmo no mais artista, no sentido técnico, dessas personalidades ora expostas diante de nós, nota-se a ausência dessa resistência formal, alma da composição; é ela, entretanto, o que mais diferencia o desenho ou a pintura de uma personalidade psicopática ou de uma criança dos de um artista ainda consciente. Em todos eles, predomina o aspecto da confidência subjetiva, a explosão do eu afetado, ou o espanto cósmico da criança diante do espetáculo eternamente novo do universo (PEDROSA, 1949, p.158).

Pedrosa observava que as artes visuais são as que mais estão ao alcance da sensibilidade infantil ou dos simples de espírito; há a necessidade da arte; não pode haver barreiras ao mundo encantado das formas; mas não se tratava de confundir arte com as amostras expostas, mesmo reconhecendo sua "evidente natureza artística".

O traçado do desenho no quadro de Klee parece simples, como também parece simples o desenho de uma criança. Porém, o simples aqui não significa que é mais fácil, pois, em seus Diários o pintor escreveu: "Se em meus trabalhos às vezes se produz uma impressão primitiva, essa 'primitividade' é explicada por minha disciplina de reduzir tudo a poucos estágios. Ela nada mais é do que economia, ou seja, o derradeiro conhecimento profissional. O contrário, portanto, da verdadeira primitividade” (p.271).

No quadro de Paul Klee, a paisagem colorida parece translúcida, brinca com o visível e o invisível. A cor é um importante elemento figurativo, mas o que vemos não é 
uma paisagem realista, e sim um efeito de paisagem, compreensível se observarmos o modo como Klee descreve suas experiência nos Diários:

Agora que eu conseguira desbravar meu caminho pelo mundo da forma, podia até voltar a ser ilustrador de idéias. Então, passei a não ver mais a arte como abstrata. Restou apenas a abstração da transitoriedade. O objeto continuava sendo o mundo, ainda que não este mundo visível” (KLEE, 1990, p.415). ${ }^{48}$

Ou, ainda, em outra passagem dirigida à sua esposa: "Até o cair da tarde, eu já tinha pintado cinco aquarelas. A última, pintada à noite, consegui captar plenamente o tom de magia da paisagem à minha volta. Um trabalho ao mesmo tempo totalmente abstrato e totalmente fiel à várzea de Lech" (p.416).

Kandinsky, no primeiro artigo da coletânea O futuro da poesia, intitulado "Arte abstrata", considerou que a condição adequada para o desenvolvimento da arte abstrata é a avaliação interior dos meios exteriores. E Klee, nos ensaios sobre a arte moderna, observou que imagens que podem se chamar construções abstratas, concretamente podem assumir nomes, de acordo com o sentido das associações comparativas que despertam. A comunicação na arte, para ambos, como ressaltou Argan, é intersubjetiva, isto é, não mediada pela referência à natureza, entendida como código comum ao artista que emite a mensagem e o fruidor que a percebe.

Consideramos que o texto de Clarice Lispector não é uma crítica à pintura de Klee, mas permite-nos pôr em questão, na maneira peculiar de apresentar suas idéias, aspectos importantes da arte moderna. Clarice não descreveu o que viu, não o descortinou, e o figurativo de Klee continua apresentando-se, para quem ler o texto da escritora, como uma "realidade mais delicada, menos visível a olho nu". Seu texto nos deixa livres para olharmos a pintura com nossos olhos. O enunciador joga com o par de palavras coragem e covardia, dando-nos a impressão de que ele está olhando de dentro de uma prisão para fora das grades. Estas palavras (prisão e liberdade) estão postas no texto explicitamente. São duas palavras que se opõem, mas, enquanto a primeira recebe uma definição ("A prisão é a segurança”), a segunda não (“a liberdade é só para muito poucos”). Observa-se

\footnotetext{
${ }^{48}$ Regina Pontieri (1999, p.186), ao encerrar o capítulo intitulado "Videntes visíveis", que aborda "o ato de enunciação enquanto visão instituinte da realidade ficcional como mundo visível: descrição e pintura...", cita palavras de Paul Klee que tratam da relação entre o pintor e a natureza, propondo que "à Clarice pintora - sobretudo de ficções, mas também de quadros, seria possível repetir as palavras de Paul Klee, pintor que muito a impressionou".
} 
que quando a palavra liberdade aparece no texto a sintaxe da frase é a mais complicada: "Assusta a visão talvez irremediável e que talvez seja a da liberdade". A linguagem dramatiza em sua materialidade o que foi vislumbrado no quadro de Klee pelo enunciador, pois observamos que, de fato, a coragem (para criar livremente) e a covardia (a obediência às normas), vacilam na escritura, acompanhado a sensação que o quadro despertou no enunciador. As frases do texto são breves, entrecortadas pela pontuação. Às vezes, uma idéia tem continuidade na próxima frase, outras vezes não, embaralhando a coerência textual. A frase "O hábito de olhar através das grades da prisão, o conforto de segurar com as duas mãos as barras, enquanto olho", parece solta, sem o predicado que lhe complemente o sentindo, pois cortada pelo ponto e seguida por outra oração: "A prisão é a segurança, as barras o apoio para as mãos". Porém, estas passagens constituem a imagem figurativa de um "eu" que, agarrado às grades de uma prisão, pensa o que isso lhe possibilita: "Pelo menos calculo o que seria a liberdade, e é isso o que torna intolerável a segurança das grades".

Não se trata de uma reescrita "ekphrástica", uma reconstrução interpretativa de um texto não-verbal, é mais uma autocrítica do enunciador à sua própria condição de artista diante da pintura de Paul Klee. O texto problematiza o olhar do artista (a escritora) para a pintura, revelando o que sente ao perceber a liberdade praticada na obra de Klee, e autoavaliando a sua própria liberdade. Reflete sobre liberdade e conformismo, e considera a incompreensão de alguns diante da liberdade:

Começo então a pensar que entre os loucos há os que não são loucos. É que a possibilidade, que é verdadeiramente realizada, não é para ser entendida. E à medida que a pessoa quiser explicar, ela estará perdendo a coragem, ela já estará pedindo. Paysage aux aiseaux jaune não pede (LE, p.136).

Ao lermos no texto "Paul Klee" a passagem acima, pensamos na incompreensão do público diante da arte moderna, associando as obras aos desenhos dos loucos, mas pensamos também em outros textos da escritora, especialmente em "Desenhando um menino" "49, que também faz parte do "Fundo de gaveta". O enunciador começa informando que não sabe desenhar o menino: "Não sei como desenhar o menino. Sei que é impossível desenhá-lo a carvão, pois até o bico de pena mancha o papel para além da

\footnotetext{
${ }^{49}$ Publicado também em 18 de outubro de 1969, no Jornal do Brasil, com o título "Menino a bico de pena".
} 
finíssima linha de atualidade em que ele vive" (LE, p.206). Seu dilema está em tentar desenhar com palavras um menino ainda nos seus primeiros momentos de vida, quando não domina a linguagem nem sincroniza os próprios movimentos do corpo. Em seguida, acrescenta: "Um dia o domesticaremos em humano e podemos desenhá-lo. Pois assim fizemos conosco e com Deus. O próprio menino ajudará sua domesticação: ele é esforçado e coopera" (LE, p.206-7). A domesticação do menino é a padronização da vida, pois o narrador informa que o menino

continuará progredindo até que pouco a pouco - pela bondade necessária com que nos salvamos - ele passará do tempo atual ao tempo do cotidiano, da meditação à expressão, da existência à vida. Fazendo o grande sacrifício de não ser louco. Eu não sou louco por solidariedade com os milhares de nós que, para construir o possível, sacrificaram a verdade que seria uma loucura (LE, p.207. Grifo nosso).

Ser louco, neste texto, corresponde a fugir dos padrões que nos tornam homens educados.

De uma perspectiva exterior ao menino, o narrador constrói uma cena familiar de uma criança e sua mãe dentro de uma casa, mas, adotando a perspectiva do menino, descreve sua sensação espacial com se a tivesse experimentado no plano da consciência: "o chão move-se incerto, uma cadeira o supera, a parede o delimita. E na parede tem o retrato de O Menino" (LE, p.207). Aqui o narrador parece experimentar não só as sensações do menino no espaço ambiente, mas também a ausência da identidade pessoal, posto que o apresenta como quem não reconhece, no próprio retrato, o "eu".

Um paralelo entre a experiência de Clarice Lispector com a percepção do menino e a experiência de Kandinsky com os rabiscos pode ser admitido se buscarmos a compreensão que Giulio Carlo Argan (1992) tem da Primeira Aquarela Abstrata (1910). Para Argan, esta aquarela "é intencionalmente um rabisco", sabidamente "a primeira fase do desenho infantil". Nesse sentido, observa que Kandinsky "se propôs a realizar experimentalmente o primeiro contato do ser humano com um mundo do qual não se sabe nada, nem mesmo sequer se é habitado", e ressalta que "a criança, sem dúvida, percebe, recebe sensações do mundo exterior, mas a percepção não se define como noção, traduz-se num conjunto de movimentos instintivos com os quais a criança pega o que atrai, afasta o que a atemoriza. Se dispõe dos movimentos necessários, transforma esses gestos em signos”. Porém, não considera que Kandinsky se dispôs a demonstrar 
que é assim que a criança vê o mundo e assim o representa, ao invés disso, se propôs "analisar, no comportamento da criança, a origem, a estrutura primária do material estético", observando que,

com efeito, todos sabem que o comportamento estético cessa quando a criança, ao crescer, aprende a 'raciocinar': a primeira experiência do mundo, isto é, a experiência estética, é esquecida, transferida para o inconsciente. Apenas poucos indivíduos - os artistas - desenvolvem-na, ligam-na a certas técnicas organizadas, delas extraem objetos que a sociedade atribui certo valor (ARGAN, 1992, p.446).

Em Do espiritual na arte, ao discutir a cor, Kandinsky (2000, p.65), observando que "sobre uma sensibilidade mediana, os objetos familiares têm uma ação superficial, ao passo que aqueles que vemos pela primeira vez logo produzem em nós uma impressão profunda", ressaltou: "É assim que a criança, para quem cada objeto é uma novidade, experimenta o mundo". Citando o exemplo da luz, observa que esta atrai a criança, "ela quer apanhá-la e queima os dedos". Com o conhecimento das propriedades da luz via experiência, "pouco a pouco, o mundo deixa de ser um mundo encantado" (p. 66).

Roberto Corrêa dos Santos (1997, p.93), analisando três estratégias discursivas em "Desenhando um menino", objetividade, detalhamento e perspectivação, identifica o texto como um "relatório técnico-científico, um esquema visual, um programa de observação, demonstração e acompanhamento de processos perceptivos, por meio dos quais explicita-se a construtividade do conhecimento". Para o crítico, a reflexão sobre o conhecimento liga-se a sua dependência da socialização e "inexiste a possibilidade de escolha. A loucura, ou a comunidade" (p.97).

Consideramos que ao lado da exposição sobre conhecer o mundo (o que está se passando com o menino) o narrador, enquanto "desenha" o menino, expõe questões sobre como representá-lo em sua atualidade incerta, distante do homem adulto (seu próprio ato). Mesmo ressaltando a impossibilidade da total ruptura com os códigos instituídos para o menino, já que ressalta: lá está o menino iniciando "tudo de novo, mas para a própria proteção futura dele, sem nenhuma chance verdadeira de realmente iniciar" (LE, p.206), o texto é o resultado da experiência estética de um "desenhista" de palavras que vê, na atualidade do menino, a origem, a estrutura primária do material estético, tornando-a visível: 
Da boca entreaberta pelo esforço de vida a baba clara escorre e pinga no chão. Olha o pingo bem de perto, como a uma formiga. O braço ergue-se, avança em árduo mecanismo de etapas. E de súbito, como para prender um inefável, com inesperada violência ele achata a baba com a palma da mão. Pestaneja, espera. Finalmente, passado o tempo necessário que se tem de esperar pelas coisas, ele destampa cuidadosamente a mão e olha no assoalho o fruto da experiência. $\mathrm{O}$ chão está vazio. Em nova brusca etapa, olha a mão: o pingo de baba está, pois, colado na palma. Agora ele sabe disso também. Então, de olhos bem abertos, lambe a baba que pertence ao menino. Ele pensa bem alto: menino (LE, p.208).

José Américo Motta Pessanha (1996), no ensaio “Clarice Lispector: o itinerário da paixão", publicado pouco depois do lançamento de A paixão segundo G.H. (1964), ao analisar este romance a partir da relação que estabelece com obras anteriores, considerou que os arautos da obra clariciana são os pobres de espírito, as crianças, os primitivos e os bichos. Para Pessanha, as crianças povoam a obra da autora

em convite à desintelectualização: caminho de retorno à realidade viva e autêntica do homem. Em convite ao eu profundo. Porque não penetraram na idade da razão, não têm ainda adestrados os instrumentos racionais de defesa. E são muito mais espontaneidade e quase só estesia: olhos espantados a olhar o mundo-aí. Descobrindo, dês-cortinando (PESSANHA, 1996, p.317).

Pessanha observa que as crianças "não treinaram a razão discursiva" e por isso “olham o mundo mais de perto", já que é próprio da razão discursiva distanciar o dado presente. Observamos que há nisso um motivo para o artista moderno desejar aproximar-se do olhar da criança, já que seu interesse, como observou Francastel, não está nas grandes distâncias, mas "na sensação em si mesma, por assim dizer, em estado bruto do órgão da percepção". Ernst Gombrich, perguntando-se sobre o desejo dos artistas modernos, formulou a seguinte resposta:

$\mathrm{O}$ artista moderno quer criar coisas. A ênfase está em criar $e$ em coisas. Ele quer sentir que realizou algo que antes não existia. Não apenas a cópia de um objeto real, por mais habilidosa, não apenas uma peça de decoração, por mais engenhosa, 
mas algo mais importante e duradouro do que ambos, algo que ele sente ser mais real que os objetos vulgares de nossa trivial existência. Se quisermos entender essa disposição de espírito, devemos voltar à nossa própria infância, à uma época em que éramos capazes de fazer coisas de tijolo ou areia, em que transformávamos uma vassoura em veículo mágico e um punhado de pedra em um castelo encantado (GOMBRICH, 1999, p.584-5).

A importância que Paul Klee atribuiu aos desenhos das crianças e dos loucos pode ser observada em uma carta de 1912, onde, referindo-se à recepção do público diante da exposição do "Blaue Reiter" ${ }^{50}$, escreveu que gostaria de tranqüilizar as pessoas que não conseguiram ver nos trabalhos expostos qualquer ligação com a obra de um artista preferido de museu, fosse ele o próprio El Greco, acrescentando:

É que ainda existem primórdios da arte, começos inexplorados, como os que se encontram em coleções etnográficas, ou em casa, no quarto das crianças. Não ria, leitor! As crianças têm essa habilidade, e há muita sabedoria no fato de terem essa habilidade! E quanto mais desamparadas, mais instrutivos são os exemplos que fornecem. É preciso protegê-las desde bem cedo para que não sejam corrompidas. Fenômenos paralelos são os que fornecem os trabalhos de doentes mentais: aqui infantilidade e loucura não são termos pejorativos, conforme geralmente empregados. Tudo isso deve ser tomado com muita seriedade, muito mais do que todas as pinacotecas juntas, se o que se pretende é a reforma da arte de hoje (KLEE, 1990, p.300-1).

É da arte moderna e da experiência estética que o enunciador do texto "Paul Klee" está tratando, mas, como observa em Paysage aux oiseaux jaune, sem se explicar. Ao enunciar que diante do quadro de Klee começa "a pensar que entre os loucos há os que não são loucos", a autora está reconhecendo os artistas, às vezes, confundidos com os loucos por quem está preso às grades da prisão.

Há uma outra versão do texto "Paul Klee", publicada no Jornal do Brasil no dia 31 de maio de 1969, com o título "Medo da libertação". O novo título é uma mudança radical. Surgem adjetivos e orações que não estavam presentes no primeiro texto: as

\footnotetext{
${ }^{50}$ A respeito do "Blaue Reiter", no Dicionário da pintura moderna (1981, p.38 ) lemos que foi o "movimento artístico mais fecundo que viu a luz do dia na Alemanha antes de 1914". Dele participaram, entre outros nomes, Wasilly Kandinsky, Franz Marc, Auguste Macke e Paul Klee.
} 
barras da prisão são agora "barras frias de ferro". Há uma oração que não estava no primeiro texto: "A covardia nos mata". E a oração "Então reconheço que a liberdade é só para muito poucos" é alterada para "Então reconheço que conheço poucos homens livres". No novo texto, o enunciador inclui a condição social para falar da prisão: "A burguesia total cai ao se olhar Paysage aux oiseaux Jaunes". Esta condição social é apontada como um empecilho para a liberdade: "O conforto da prisão burguesa tantas vezes me bate no rosto". Juntamente com outras alterações, contribui para que se fale em um novo texto.

O texto "Paul Klee" foi publicado em 1964. Neste ano, instalou-se no Brasil o regime militar. Roberto Schwarz (1978, p.62-3), em artigo em que assume o erro do seu prognóstico, observa que, no período que vai de 1964 a 1968, "para surpresa de todos, a presença cultural da esquerda não foi liquidada", e isso por causa do hiato que havia entre a produção da esquerda e as massas. "Cortadas naquela ocasião as pontes entre o movimento cultural e as massas, o governo Castelo Branco não impediu a circulação teórica ou artística do ideário esquerdista, que embora em área restrita, floresceu extraordinariamente". Apenas quando, por força da "intelectualidade de esquerda", que seguia "estudando, ensinando, filmando, falando etc", surgiu, no interior da pequena burguesia, uma geração "maciçamente anti-capitalista", "o regime respondeu, em dezembro de 68, como o endurecimento". Portanto,

se em 64 fora possível a direita "preservar" a produção intelectual, pois bastara liquidar o contato com a massa operária e camponesa, em 68, quando o estudante e o público dos melhores filmes, do melhor teatro, da melhor música e dos melhores livros já constitui massa politicamente perigosa, será necessário trocar ou censurar os professores, os encenadores, os escritores, os músicos, os livros, os editores - noutras palavras, será necessário liquidar a própria cultura viva do momento (SCHWARZ, 1978, p.63).

No dia 13 de dezembro de 1968, Costa e Silva baixou o AI-5, fechando o Congresso. A partir deste ato, como escreveu Boris Fausto (2006, p.480), "abriu-se um novo ciclo de cassação, perda de direitos políticos e expurgos do funcionalismo, abrangendo muitos professores universitários, a tortura passou a fazer parte integrante dos métodos do governo". Nesses anos, "o regime seguia cada vez mais o curso de uma ditadura brutal", e "as ações armadas se multiplicaram". Sua eficiência se mostrou tanto 
por ter acabado com um setor "significativo mas minoritário da sociedade, adversário do regime", quanto pelo sucesso da propaganda em função do grande avanço das telecomunicações e da facilidade de crédito, que permitiu a ampliação do número de televisores nas residências, alcançando "a massa da população que vivia um dia-a-dia de alguma esperança nesses anos de prosperidade econômica” (p.484).

No dia 17 de fevereiro de 1968, Clarice Lispector publicou no Jornal do Brasil o texto intitulado "Carta ao Ministro da Educação", reclamando de verba para a educação que possibilitasse a entrada na universidade daqueles classificados como "excedentes" no vestibular. Sobre a condição destes excedentes, escreveu: "Nem poderiam sair à rua para uma passeata de protesto porque sabem que a polícia poderia espancá-los”. Ao final, declara: "Que estas páginas simbolizem uma passeata de protesto de rapazes e moças" (DM, p.77).

No mesmo ano, a repressão ao movimento estudantil culminou na morte do estudante Edson Luís durante a passeata do dia 28 de março. A esse respeito, a biógrafa Teresa Montero Ferreira escreveu:

O Brasil de 1968 vivia num clima de extrema agitação social. O movimento estudantil ganhava força e o governo militar de Costa e Silva reprimia as manifestações 'subversivas'. Quando o estudante Édson Luís de Lima Souto foi morto por soldados da Polícia Militar durante uma passeata, a situação ficou insuportável [...]. Hélio Pellegrino foi escolhido o representante dos cerca de 300 intelectuais e artistas que foram ao palácio, no dia 22 de junho, dentre eles, Carlos Scliar, Glauce Rocha, Oscar Niemeyer, Tônia Carrero, Caetano Veloso e Clarice Lispector. Ela já demonstrara seu apoio aos movimentos estudantis alguns dias após a morte de Édson Luís. Ao fim de uma crônica, no dia 6 de abril de 1968, acrescentou: P.S. - Estou solidária, de corpo e alma, com a tragédia dos estudantes do Brasil. [...] (FERREIRA, 1999, p.241).

De acordo com Ferreira, durante o encontro, Hélio Pellegrino expunha os últimos acontecimentos violentos e o governador Negrão de Lima atenuava a situação, mas quando o deputado Márcio Moreira Alves o agrediu verbalmente, os ânimos se exaltaram. O governador perdeu o controle e a situação agravou-se. Os desdobramentos do encontro resultaram na Passeata dos Cem Mil, no dia 26 de junho, que foi noticiada 
no dia seguinte pelo jornal Última hora. Numa foto que registra a passeata, Clarice Lispector aparece ao lado de outros artistas.

A nova versão do texto "Paul Klee", intitulada "Medo da libertação" foi publicada em 1969 e refere-se mais explicitamente a aspectos relevantes do contexto brasileiro do período da repressão, como perda de liberdade, impotência do homem burguês diante da situação social, mas não rompe com o estilo clariciano, e talvez por isso tenha sobrevivido à censura.

O pintor Paul Klee (2001.p.66) observou que as realidades da arte levam a vida para além do que ela apresenta ser por uma perspectiva mediana "porque as obras de arte não só reproduzem com vivacidade o que é visto, mas também tornam visível o que é vislumbrado em segredo". O texto de Clarice Lispector parece-nos uma realização perfeita deste pensamento.

\section{"Abstrato e Figurativo"}

No pequeno texto intitulado "Abstrato e figurativo", a escritora expõe o modo como entende o abstrato em arte:

Tanto em pintura como em música e literatura, tantas vezes o que chamam de abstrato me parece apenas o figurativo de uma realidade mais delicada e mais difícil, menos visível a olho nu (LE, p.151).

No lugar de oposição entre abstrato e figurativo, observa-se aproximação. Abstrato e figurativo não são termos de sentidos opostos entre si, como algumas vezes verifica-se em contextos que buscam ressaltar, por exemplo, que a arte pode ser independente de toda relação com as imagens da realidade visual, podendo, como Antoni Tàpies (1979, p.15) $)^{51}$ observou, “encontrar-se uma expressividade das cores e formas puras".

À arte abstrata que se opõe à arte figurativa, podemos repetir as palavras de Frances Vicens, observando que a primeira se aplica

a obras inteiramente carentes de figuração (espaço real, objetos, paisagens, figuras de seres animados e inclusive formas geométricas se representadas como objetos reais, com iluminação e perspectiva). Trata-se de uma arte que repele a cópia ou a

\footnotetext{
${ }^{51}$ Antoni Tàpies, entrevistado por Frances Vicens In: Arte abstrata e arte figurativa. Rio de Janeiro: Salvat, 1979.
} 
imitação de todo modelo exterior à consciência do pintor. Partindo deste conceito, não pode haver, num quadro abstrato, referência a algo independente do próprio quadro: figura humana, paisagem, mesa, fruta, etc., que são objetos definidos por palavras (VICENS, 1979, p.24).

Trata-se, porém, de um modo de compreender a arte abstrata, opondo-a ao figurativo. No entanto, definir o abstrato e o figurativo em arte não é simples, mesmo porque as rupturas com o figurativo não se dão apenas abandonando a representação dos "objetos definidos por palavras". Daí a importância de situarmos em qual contexto se está falando em arte abstrata.

De acordo com Dora Vallier (1986, p.10), a abstração, lucidamente concebida, nascida da própria essência da arte, como aconteceu no século $\mathrm{XX}$, nunca existiu antes deste século. "A forma, sempre que se afastou da representação realista, chegou a uma aparência de abstração, mas não pode ser considerada abstração no sentido da arte dos nossos dias". Observando uma evolução da arte abstrata, Dora Vallier destacou que,

por um lado, inicialmente, a abstração tende a ser uma ciência da beleza concebida como uma ordem e uma harmonia: é a chamada 'abstração geométrica'. Em seguida, a partir de 1945, assistimos a uma outra abstração, que já não é a procura da forma, mas que, pelo contrário, é o desejo de exprimir, antes da forma e mesmo fora dela, toda a riqueza e espontaneidade da vida interior, projetando-se o artista inteiramente na sua obra: é a chamada abstração 'lírica' ou 'informal' (VALLIER, 1986, p.16).

Paul Klee, ao destacar a abstração em termos de "abstração da transitoriedade", para nós, também considera o figurativo de uma realidade menos visível a olho nu, na medida em que acrescenta que o objeto continua sendo o mundo, ainda que não este mundo visível. Nos anos 1950, Mário Pedrosa considerou que, entre os artistas mais atuais das correntes abstracionistas entre nós, estava Paul Klee.

$\mathrm{O}$ artista moderno tem uma nova relação com o mundo visível. Para ele, a forma artística, não sendo representativa, não deixa de comunicar. Nesse sentido, Klee (1990, p.121), a respeito dos afrescos de Marées, observados quando, em 1902, esteve em Nápoles, escreveu em seus Diários: "Há meio ano, o tema ainda me teria sido 
totalmente estranho; agora, porém, já chego a compreendê-lo. Mas a forma de representação, esta sim me fala muito ao coração".

Giulio Carlo Argan, ao iniciar um capítulo sobre "A crise da representação", no pequeno volume Arte e crítica de arte, começa por destacar que

o facto que separa nitidamente, com um autêntico salto qualitativo, a arte do nosso século de toda a arte do passado, pelo menos na área ocidental, é a passagem do caráter figurativo ao não figurativo, ou como é corrente dizer-se, à abstração. Esta viragem tem sido interpretada de várias maneiras: como indício mais significativo da crise ou, ao contrário, como instauração de sistemas de signos já não deduzidos do modelo da morfologia natural e como libertação da criatividade humana de qualquer condicionante princípio de autoridade (ARGAN, 1995, p. 105).

Argan, observando que se tem imputado aos sistemas de signos não-naturalistas "a incomunicabilidade da arte contemporânea e a sua demarcação relativamente às experiências e aos interesses da sociedade", considera que, pelo contrário, a demarcação depende do fato de que, "por um preconceito inveterado, muitos continuam a querer servir-se, para decifrar as mensagens artísticas, do código da morfologia natural, a que já ninguém pensa recorrer para outros tipos de comunicação, por exemplo, as da ciência" (p.105). Daí, primeiramente observando o momento da passagem do figurativo ao não-figurativo, em 1910/1911 (quando Kandinsky pinta a primeira aquarela abstrata, escreve Über das Geistige in der Kunst, publicado em 1912, e dá vida em Munique, com Klee, Marc e Macke, ao movimento Blaue Reiter), e depois detendo-se nas questões da representação, considera que a grande novidade de Kandinsky e do Blaue Reiter "não foi a renúncia à figuração, mas a renúncia à representação como processo intelectivo próprio da arte: noutros termos, a substituição da forma pelo signo". Para Argan,

não só Kandinsky recusa o genérico espiritualismo simbolista, como, para evitar qualquer ambigüidade entre signo e símbolo, procura instaurar uma 'ciência' dos signos, partindo da primeira análise dos elementos básicos do ponto, da linha, da superfície: às teorias da forma substitui-se assim uma teoria dos signos (Ibid., p. 108). 
Sendo assim, considera que é possível haver representações não-figurativas, a pintura de Mondrian, por exemplo, e, ao contrário, pintura figurativa que não é representativa - Chagall, “que vagueia numa dimensão fantástica em que as imagens se fazem e desfazem como nuvens no céu, mas não se coloca de modo nenhum o problema da definição formal da experiência da realidade" (p.110).

O pequeno texto de Clarice Lispector, observando que há um figurativo diferente naquilo que se costuma chamar de abstrato, relaciona-se com sua narrativa. A esse respeito, Carlos Mendes de Souza destacou que o texto

como se lê, pretende contestar a rigidez das tabelas classificatórias. A polaridade pode aparecer associada às categorias da narrativa (à acção, às personagens), como acontece, por exemplo em $A$ hora da estrela, quando o narrador afirma, no início, tratar-se de um livro onde se dá a ver uma expressão do figurativo por causa dos fatos. Mais próximo do final, sobre as personagens afirmará serem elas abstratas... (SOUSA, 2000, p.292).

Ao propor este paralelo, Sousa considera que "a escrita de Clarice Lispector se encontra mais próxima de um modelo de pintura não figurativa onde se poderia encontrar uma adequação às descrições de estados interiores, a visões interiores do ser" (p.292). O risco, nesse caso, é definir o não-figurativo de Lispector por "descrição" de estados interiores.

Nas narrativas aqui estudadas, observamos que há um figurativo não representativo, "mais delicado, menos visível a olho nu". Na pintura de Francis Bacon, Deleuze, denominou-o de "Figura multissensível".

Chagall foi um pintor de quem Clarice se aproximou ao entrevistar a artista plástica Flora Morgan Snell. A autora, após perguntar à entrevistada sobre suas afinidades, esclareceu o que quis dizer citando-se como exemplo: “- Estava longe de mim insinuar qualquer plágio ou sequer influência; eu apenas me referia a afinidade. Por exemplo, eu, que não sou pintora, tenho afinidade com Chagall” 52 .

\footnotetext{
${ }^{52}$ A referida entrevista, sem indicação de data, encontra-se na seção Arte de um recorte de revista pertencente ao arquivo da autora na Fundação Casa de Rui Barbosa. Foi, possivelmente, publicada entre os anos 1976 e 1977, quando apareceu uma série de entrevistas feitas pela autora para a Revista Fatos e Fotos: Gente, nas seções Artes, Literatura, Ecologia, Depoimentos e Exclusivo. Ver anexo 3.
} 
Em uma nota de referência sobre as traduções de Clarice Lispector, Sousa (2000, p.287) acrescentou que, a propósito de Marc Chagall, "no arquivo da escritora [Fundação Casa de Rui Barbosa] se encontra um recorte sobre o pintor. Trata-se de um texto em inglês da autoria de Carlton Lake e que data do período em que Clarice viveu nos Estados Unidos".

No artigo “Arte Abstrata”, Kandinsky (1996, p.208) destacou que a diferença entre arte figurativa e arte abstrata é muito menos de natureza e mais de deslocamento do centro de gravidade do material para o espiritual. Para ele, a existência de uma arte abstrata se legitima pela avaliação interior dos elementos da arte, mesmo porque, como escreveu, "se avaliarmos de maneira puramente exterior e fria o elemento formal na arte (e na 'vida') as obras de arte abstratas são obras mortas". O autor observou também que uma das maiores questões que se acham naturalmente em estreita relação com o problema geral da arte abstrata era o problema do conteúdo e da forma.

Merleau-Ponty, em "A linguagem indireta e as vozes do silêncio", considerou que o espectador não deve contar com outro guia além do movimento da linha inventada, do traçado incorpóreo, para reunir-se ao mundo silencioso do pintor, só então, proferido e acessível. Com isso, entendemos que o espectador, se quiser ouvir a voz silenciosa da pintura, precisa perceber não a forma dada de antemão como cópia de um referente, mas a forma criada pelo artista; dito de outro modo, o espectador e o leitor deverão perceber o movimento que, em cada obra, constitui-se em um visível que alude a determinado conteúdo.

Na obra Onde estiveste de noite (1974), de Clarice Lispector, o texto "Seco estudo de cavalos" é composto de diferentes textos que têm em comum a figura do cavalo. "Forma", reproduzido abaixo, é um desses textos e nos diz muito sobre o modo como a autora entendeu a comunicação pela forma:

\section{"Forma"}

A forma do cavalo representa o que há de melhor no ser humano. Tenho um cavalo dentro de mim que raramente se exprime. Mas quando vejo outro cavalo então o meu se expressa. Sua forma fala (OEN, 1999, p.44).

No fragmento acima, a idéia de um "eu” que se exprime a partir da visualização de uma forma externa de um "outro", que dialoga com o que o "eu" tem dentro de si, 
explicita a idéia de uma comunicação intersubjetiva que Argan ressaltou em Klee e Kandisnky.

Em 1969, Clarice Lispector publicou no Jornal do Brasil um texto intitulado "Forma e conteúdo" no qual se lê: "A dificuldade de forma está no próprio constituir-se do conteúdo, no próprio pensar ou sentir, que não saberiam existir sem sua forma adequada e às vezes única”.

Se pensarmos agora esses aspectos da forma em relação ao que Clarice Lispector escreveu em "Gastão Manoel Henrique" e "Paul Klee", perceberemos que seus textos constituem formas que resultam da comunicação com outras formas. Nesse sentido, a autora realizou algo muito difícil, pois seus textos não fogem do visto, mas também não o aprisiona. Ortega y Gasset compreendeu que dificuldade há em construir uma arte que fale por uma forma não representativa, ao ressaltar que

o vulgo crê que é coisa fácil fugir da realidade, quando é o mais difícil do mundo. É fácil dizer ou pintar uma coisa que careça completamente de sentido, que seja ininteligível ou nula: bastará enfileirar palavras sem nexo, ou traçar riscos ao acaso. Porém, conseguir construir algo que não seja cópia do 'natural' e que, não obstante, possua alguma subjetividade, implica o dom mais sublime (ORTEGA y GASSET, 2005, p.43).

No fragmento do texto "Seco estudo de cavalos", o cavalo é o figurativo de um não-figurativo, pois é mais do que "morfologia natural", para usarmos uma expressão de Argan. Há uma ambigüidade na expressão "sua forma fala". Esta expressão tanto pode se referir à forma do cavalo que o enunciador visualiza ("Mas quando vejo outro cavalo"), quanto à forma do cavalo interno que o enunciador possui ("Tenho um cavalo dentro de mim”). No jogo entre o visível e o invisível clariciano quem fala tanto é a forma do outro quanto a forma interna do "eu", ao ter a experiência de perceber o outro.

Em Um sopro de vida (1978), a personagem Ângela Pralini aborda o título de um quadro pintado por Clarice Lispector, "Gruta" (1975), como se ela o tivesse pintado:

Meu ideal seria pintar um quadro de um quadro.

Vivo tão atribulada que não aperfeiçoei mais o que inventei em matéria de pintura. Ou pelo menos nunca ouvi falar desse modo de pintar: consiste em pegar uma tela de madeira - pinho de riga é a melhor - e prestar atenção às suas 
nervuras. De súbito, então vem do subconsciente uma onda de criatividade e a gente se joga nas nervuras acompanhando-as um pouco - mas mantendo a liberdade. Fiz um quadro que saiu assim: um vigoroso cavalo com longa e vasta cabeleira loura no meio de estalactites de uma gruta. É um modo genérico de pintar. E, inclusive, não se precisa saber pintar: qualquer pessoa contanto que não seja inibida demais, pode seguir essa técnica de liberdade. E todos os mortais têm subconsciente (SV, p.49-50).

A descrição do "modo genérico de pintar" faz-nos pensar nas pinturas feitas em cavernas pré-históricas. Fayga Ostrower (1988, p.168) destaca as seguintes observações sobre os desenhos encontrados no teto e paredes dessas cavernas:

São incisões feitas na rocha, com o único instrumento de que o homem dispunha naquela época: uma pedra. Então era pedra contra pedra. Acompanhando a conformação natural da própria rocha, ou seja, aproveitando certas cavidades ou saliências que pudessem sugerir as formas do animal, o artista gravava os sulcos das linhas de contorno, colorindo as áreas com pigmentos naturais: terra, que são os tons de ocre, óxido de ferro para o vermelho, carvão para o preto. Tais pigmentos eram misturados a gorduras animais e esfregados na superfície áspera das rochas (OSTROWER, 1988, p.168).

Ostrower observa nas imagens das cavernas a extraordinária "caracterização da dignidade e majestade dos animais [...]. O animal como que carrega uma série de qualificações, pelas quais o homem talvez o admirasse e com as quais também se identificasse", pois, ressalta, "na pré-história não existe a figura do homem", os homens se identificavam "a tribos dos leões, dos cavalos, etc". E acrescenta: "Além da caracterização de certas qualidades, vemos os animais representados em seu momento de maior vitalidade e tensão, estejam vivendo ou mesmo morrendo. A tensão é muito grande, o corpo maciço expandindo, o olhar fixo", sempre imagens de animais de caça, o que reforça a hipótese de magia como motivação inicial para homens que pensam que através da imagem poderão dominar e possuir os animais. "Muitas vezes vemos a silhueta da mão humana posta literalmente em cima da figura do animal - tomando posse dele, numa ação mágica" (168-7). 
Poderíamos pensar que o quadro de Ângela Pralini repete o processo desse tipo de pintura, porém, o destaque de sua descrição está em ter atingindo a representação sem que para isso partisse da cópia do real.

Para Giulio Argan, Paul Klee compreendeu que o contraste entre representação e não-representação "comprometia a unidade do conceito de arte e acelerava-lhe a crise", pois

em toda a sua obra de pintor e de gráfico, parte do acto inicial e quase involuntário do signo para reconstruir, com a trama subtil dos signos, o tecido já vital da imagem e, depois, remontar até uma estruturação delicada, capilar, da forma que, portanto, nunca é dada como representação completa, mas como processo agregador, formação em acto (Gestaltung) (ARGAN, 1995, p.112).

É nesse sentido que os textos "Gastão Manoel Henrique" e "Paul Klee" estão se aproximando dos objetos artísticos a que aludem e a obra de Clarice Lispector aproximando-se de diversas realidades e umas das outras, mas nunca se dando como representação completa.

\section{"Irmãos"}

O texto encerra um diálogo entre dois irmãos sobre o que é concreto e o que é abstrato. Os dois brincam de apontar coisas - o quadro no qual se pinta os sentimentos, o quadro no qual as linhas deixam ver um mapa, o teto, o fantasma e a mãe - como concretas ou abstratas.

Em um dos artigos publicados no Suplemento Literário do Jornal do Brasil, intitulado "Van Doesburg", entre outros aspectos sobre as idéias artísticas de Doesburg, Ferreira Gullar (1999) destacou sua participação como um dos fundadores do movimento De Stijl e sua concepção de pintura formulada na revista Arte concreta:

Pintura concreta e não abstrata, porque nada é mais concreto, mais real, que uma linha, uma cor, uma superfície. Uma mulher, uma árvore ou uma vaca são, numa tela, elementos concretos? Não - uma mulher, uma árvore, uma vaca são concretos em estado natural, mas em estado de pintura são mais abstratos, mais ilusórios, mais vagos, mais especulativos que um plano ou uma linha (DOESBURG, Apud GULLAR, 1999, p.169). 
Tais idéias de Doesburg, para Ferreira Gullar (1999, p.169),

não traziam nada de novo à problemática da arte abstrata, tal como colocara Mondrian quinze anos antes. Mas a intenção de ver as linhas, formas e as cores como objetos tão concretos como os objetos naturais teria uma influência enorme sobre a arte construtiva e seria responsável por um exacerbamento analítico que conduziria a pintura dessa tendência ao esquecimento de seus propósitos iniciais, mais amplos e fecundos (Ibid).

No texto de Clarice Lispector, a brincadeira de saber se algo é concreto ou abstrato é cômica ao servir para os irmãos se sentirem inteligentes, gênios ou artistas. A autoridade para decidir se algo é concreto ou abstrato pertence àquele que se assumir como autor da obra:

- Mas agora vamos brincar de outra coisa. Quero saber se o senhor é inteligente. Este quadro é concreto ou abstrato?

- Abstrato

- Pois o senhor é burro. É concreto: fui eu que pintei, e pintei nele meus sentimentos e meus sentimentos são concretos (LE, p213).

$\mathrm{Na}$ série de artigos sobre Arte Concreta, Gullar observava que o intuito de Doesburg era "dar o que considerava ser o nome exato a uma arte que se tinha desprendido totalmente da imitação da natureza". Observando que Arp e Kandinsky adotaram em certa altura a denominação, ressaltou que "até aí não havia diferença teórica entre arte concreta e arte abstrata, tratando-se apenas de uma opção terminológica a adoção de uma ou outra terminação". É com a criação da Escola Superior da Forma, em Ulm, após 1951, que, segundo o autor, a arte concreta toma corpo de movimento. Sobre a origem do movimento, recorrendo às palavras de Tomás Maldonado publicadas em 1955, informou:

Não obstante, essa diferença entre arte abstrata e arte concreta, que no começo era apenas nominalista, tende hoje a assumir outro significado. Cada dia acreditamos - torna-se mais evidente que a arte abstrata difere da concreta, que as 
duas expressões designam fatos artísticos essencialmente diversos. Essa transformação, sem nenhuma dúvida, deve-se sobretudo à contribuição criadora do qualificado grupo de artistas concretos suíços - Max Bill, Camille Graeser, Richard P. Lohse, Verena Loewnsberger - que abriram novas perspectivas e uma definição da arte concreta sobre novas bases (MALDONADO, Apud GULLAR, 1999, p.213).

Para Roberto Pontual (1973, p.38), as conferências de Tomás Maldonado - "um dos responsáveis pelo movimento de arte não-figurativa na Argentina e mais tarde professor da Escola Superior da Forma, co-fundada por Bill em Ulm" - no Museu de Arte Moderna do Rio de Janeiro, depois da I Bienal de São Paulo, aprofundam entre nós "a absorção da abstração geométrica no rumo do concretismo". Além da I Bienal de São Paulo, o autor ressalta a ampla mostra da obra de Max Bill no Museu de Arte daquela cidade, em 1952, como impulsos para que alguns artistas brasileiros assumissem o rigor da arte concreta.

Explicando a concepção de Max Bill sobre a arte concreta, Gullar escreveu:

Para maior clareza recordemos que, para Bill, o concreto é 'o que existe na realidade, o que não é apenas conceito. Isto é, a arte concreta acentua o caráter objetivo, verificável, praticamente verificável, da imagem final: 'uma realidade que possa ser controlada e observada [...]. Na verdade, a estética concreta, segundo a formulação de Bill, propõe a criação de uma arte baseada numa concepção matemática (GULLAR, 1999, p.214).

Como sabemos, Ferreira Gullar e outros artistas farão oposição ao rigor da arte concreta, mais precisamente àquilo que consideravam o "caráter radical do conceito puramente visual da forma". O "Manifesto Neoconcreto", de 1959, começava ressaltando justamente a oposição desses artistas a esse caráter: "A expressão neoconcreto é uma tomada de posição em face da arte não-figurativa 'geométrica' (neoplasticismo, construtivismo, suprematismo, Escola de Ulm) e particularmente em face da arte concreta levada a uma perigosa exacerbação racionalista".

Hélio Oiticica (2006, p.87), no artigo “A transição da cor do quadro para o espaço e o sentido da construtividade", publicado originalmente em Habitat 70 (1962), 
comentava sua transição do quadro para o espaço, iniciada em 1959, e, discutindo o construtivismo na arte moderna, considerava "inadiável e necessária uma reconsideração do termo 'construtivismo' ou 'arte construtiva' dentro das novas pesquisas em todo o mundo. Para o autor,

seria pretensioso querer considerar, como o fazem teóricos e críticos puramente formalistas, como construtivo somente as obras que descendem dos Movimentos Construtivistas, Suprematistas e Neoplasticistas, ou seja, a chamada arte 'geométrica', termo horrível e deplorável tal a superficial formulação que o gerou, que indica claramente o seu sentido formalista (OITICICA, 2006, p.87).

Preferindo em lugar do termo "arte geométrica", o termo "arte construtiva", Oiticica considerava que este abrangeria "uma tendência mais ampla na arte contemporânea, indicando não uma relação formal de idéias e soluções, mas uma técnica estrutural dentro desse programa, defendendo que o espírito de construção frutificou em todas as épocas, "mas na nossa esse espírito tem um caráter especial; não a especificidade formalista que considera como 'construtivo' a forma geométrica nas artes, mas o espírito geral que desde o aparecimento do cubismo e da arte abstrata (via Kandinsky) anima os criadores do nosso século". Identificando diferentes tipos de artistas construtores, citou, entre outros nomes: Kandinsky, Mondrian, Klee, Arp, Tauber-Arp, Schwitters, Malevitch, Calder, Kupka, Magnelli, Jacobsen, David Smith, Brancusi, Picasso, Braque, Juan Gris, Gabo, Pevsner, Boccioni, Max Bill, Baumeiter, Dorazio, Pollock, Lygia Clark, Louise Nevelson, Yves Klein, etc.

Em 1977, a escritora Clarice Lispector entrevistou o poeta Ferreira Gullar para a revista Fatos e Fotos. Ao apresentar o entrevistado, escreveu:

Sou fervente admiradora de Ferreira Gullar, desde os tempos de A luta corporal [1954] até esse escandalosamente belíssimo Poema sujo [1976]. Nossos mútuos contatos se fizeram no tempo da primeira revista Senhor, para qual nós dois escrevíamos. Mas eu tinha um pouco de medo dele, parecia-me que, com seu extraordinário poder verbal, eu seria aniquilada. Éramos um pouco distantes um do outro, e eu desconfiava que ele rejeitava a minha 'literatura'. Mas o que fazer? Nada, senão continuar a gostar do que ele escrevia e escreve $[\ldots](E$, p.51). 
À pergunta de Clarice sobre qual sua opinião a respeito da fala de Glauber Rocha de que o Poema sujo (1976) é o ponto culminante do concretismo, Gullar respondeu:

Poema sujo não tem nada a ver com o concretismo. [...] O Poema sujo incorpora toda a minha experiência formal e, no aspecto gráfico, se liga ao neoconcretismo. Conversando posteriormente com Glauber, soube que ele nessa frase, usando a expressão concretismo, incluía a poesia neoconcreta (GULLAR, Apud LISPECTOR, 2007, p.54).

No texto "Dois Irmãos", a aproximação entre o concreto e o abstrato é sugerida pelos laços familiares que unem os dois personagens. Como pode ser observado ao longo do diálogo, o texto opõe-se ao emprego do termo concreto para se referir ao que existe apenas materialmente, pois, na brincadeira de adivinhar o que é concreto e o que é abstrato, as crianças ressaltam, mais do que a diferença entre o que existe materialmente e o que existe em pensamento, a aproximação, já que, de um lado, apontam para a concretude dos sentimentos humanos como o medo e, de outro, não têm certeza se aquilo que existe, visto de um novo modo, ainda pode ser considerado concreto:

- Vou explicar ao senhor o que é concreto é...

- ... está errado

- Por que?

- Porque eu não entendo. Quando eu não entendo, é porque está errado. E agora quero saber: isso é compreto?

- O senhor quer dizer concreto.

- Não, é compreto mesmo. É porque sou um gênio e todo gênio tem pelo menos que inventar uma coisa. Eu inventei a palavra compreto. Música é compreta?

- Acho que é, porque a gente ouve sente pelos ouvidos.

- Ah!, mas o senhor não pode desenhar!

- O senhor acha que o teto é concreto?

$-\dot{E}$

- Mas se eu virasse essa parede e botasse ela na posição do teto, ela ia ficar uma parede-teto, e essa parede teto ia ser concreto?

- Acho que talvez. Fantasma é concreto? 
- Qual? o de lençóis?

- Não, o que existe.

- Bem... Bem, seria supostamente concreto.

- Mãe é concreto ou abstrato?

- Concreto, é claro, que burrice (LE, p.214).

Observando o diálogo, parece que concreto é aquilo que é, aquilo que existe, seja porque se sente, como a música, ou porque se acredita nele, como o fantasma. Mas também é aquilo que passa a existir, como a palavra compreto que, tendo inicialmente causado estranhamento, quando explicada, serviu para decidirem que a música é compreta. Algo concreto como o teto, quando modificado para um teto-parede pode deixar de ser concreto. Os dois personagens vacilam nas decisões: para um deles, o tetoparede talvez seja concreto, e, para outro, o fantasma invisível ("não o de lençóis") seria supostamente concreto. Não há rigidez nas classificações, apenas quanto à mãe não há dúvida de que é concreto. Ao final do texto, aparece o narrador de terceira pessoa ressaltando a concretude da mãe e do sentimento materno: "No quarto ao lado a mãe parou de coser, ficou com as mãos imóveis no colo, inclinando um coração que este batia todo concreto" (LE, p.215).

\section{"Uma porta abstrata"}

Este texto começa com o enunciador distinguindo o abstrato do literário: "Sob certo ponto de vista, considero fazer coisas abstratas como o menos literário" (LE, p. 227).

A falta de conceituação dos dois termos dificulta a compreensão do texto. Porém, observa-se que é por meio dos exemplos dados que o enunciador pretende se fazer entender, pois, logo em seguida, ressalta: "Certas páginas, vazias de acontecimento, me dão a sensação de estar tocando na própria coisa, e é a maior sinceridade. É como se eu esculpisse" (LE, p.227). O exemplo dado é o da narrativa que não narra acontecimentos, no entanto, parece, para o enunciador que a produz, tocável como uma escultura.

Sabemos que desde o primeiro romance da escritora a crítica reclamou, de diferentes modos, da falta de realismo em sua ficção. Álvaro Lins (1963, p.190), ao escrever sobre Perto do coração selvagem, em crítica que a abateu ${ }^{53}$, destacou que faltou à Clarice Lispector "os recursos da estruturação ficcional”. Anos depois, também sobre

${ }_{53}$ Como pode ser verificado na carta de Lispector, datada de 16 de fevereiro de 1944, à sua irmã Tânia Kaufmann. 
seu primeiro romance, Luiz Costa Lima (1970, p.455), ao discutir a "desarticulação com o real" na narrativa, ressaltou que a luta individual da protagonista Joana "cada vez mais se subjetiviza e ingressa na divagação abstrata". Benedito Nunes (1989, p.19), na leitura de Perto do coração selvagem, observou que os episódios da primeira parte, "sem traço de intriga ou enredo, fundem lembranças e percepções momentâneas, idéias gerais abstratas e imagens". Posteriormente, nas muitas edições da História concisa da literatura brasileira, a primeira data de 1970, Alfredo Bosi (1994, p.424) escreveu que "os analistas à caça de estruturas não deixarão tão cedo os textos complexos e abstratos de Clarice Lispector". Há muitos outros exemplos de críticas que consideraram a linguagem narrativa da autora abstrata porque não atendia aos paradigmas da narrativa tradicional.

No texto "Uma porta abstrata", o enunciador enfatiza a forma para ressaltar o aspecto "concreto" da arte. À pergunta elaborada "Qual é a mais verdadeira escultura de um corpo?”. Segue a resposta: “O corpo, a forma do corpo, a expressão da própria forma do corpo".

Para que possamos entender em que sentido o abstrato é menos literário, devemos observar outro exemplo do texto:

Uma Vênus nua, em pé, 'inexpressiva', é muito mais do que a idéia literária de Vênus. Estou chamando 'idéia literária de Vênus', uma Vênus, por exemplo, que tivesse no rosto um sorriso de Vênus, um olhar de Vênus, como um título. A Vênus de Milo - é uma mulher abstrata (LE, p.227).

Nesse sentido, abstrata é a obra que atende a uma forma dada a priori, a uma idéia literária. Pelo contrário, uma obra livre de atender a certa forma dada é "o figurativo de uma realidade mais delicada e mais difícil, menos visível a olho nu".

O último exemplo que aparece no texto é do desenho de uma porta: "(Se eu desenhar num papel, minuciosamente, uma porta, e se eu não lhe acrescentar nada meu, estarei desenhado muito objetivamente uma porta abstrata)".

Em Perto do coração selvagem, Joana compara certos instantes de ver a certos instantes em que o pensamento cria algo, permitindo-nos perceber em que sentido, para ela, ver e pensar são atos criativos. Seu exemplo de "uma porta aberta a balançar para lá, para cá, rangendo no silêncio de uma tarde... E de repente, sim, ali estava a coisa verdadeira [...]. (PCS, p.54) nos permite pensar em uma comparação entre a narrativa 
clariciana e o desenho de uma porta não abstrata porque inventada, livre de acatar uma idéia pronta de porta. Nesse sentido, consideramos que a escritora, consciente de que quando sua narrativa é chamada de abstrata é porque esta não atende ao paradigma de conto ou romance que o leitor pode ter, em "Uma porta abstrata", diz que atender a uma determinada "idéia literária" é ser abstrata e, portanto, menos literária, sem criação.

Benedito Nunes (2002), ao escrever sobre "Arte e conhecimento", em Introdução à filosofia da arte, atendo-se aos escritos de Ernst Cassirer (1874-1945), ressaltou a concreção da arte e a abstração da ciência com as seguintes palavras:

Na ciência, o pensamento se eleva ao grau máximo de abstração e generalidade, de modo a proporcionar-nos o conhecimento adequado da realidade, que condiz com a ordem lógica dos conceitos. Na Arte é a concreção, o inverso da abstração, que prevalece: é o singular, o particular, que se sobrepõe ao geral. Em vez da ordem lógica dos conceitos, deparamos com significações irredutíveis ao pensamento discursivo, e que, no entanto, possui a lógica imanente às formas sensíveis e individuais em que se concretizam. Para Cassirer, essa lógica é a vida dinâmica das formas artísticas - plásticas, musicais e poéticas - que articulam as cores, as linhas, os ritmos, as palavras, em conjuntos significativos, que não apenas 'traduzem' os sentimentos do artista, mas lhe conferem uma existência palpável e objetiva, que não somente exteriorizam a sua percepção das coisas, mas transformam essa percepção num modo autêntico de ver e sentir (NUNES, 2002, p.69-70).

Clarice Lispector utiliza o termo "abstração" com o qual foi criticada para ressaltar o aspecto concreto do que realiza.

Em 1970, o texto "Abstrato e figurativo" foi publicado no Jornal do Brasil com uma alteração sutil no título: "Abstrato é o figurativo". No mesmo ano, outros três textos da autora tratam da crítica de seus romances. O primeiro deles, "Ficção ou não", foi publicado no dia 14 de fevereiro e é uma resposta da escritora à crítica feita ao romance A paixão segundo G.H. O texto começa com a seguinte ressalva da autora:

Estou entrando num campo onde raramente me atrevo a entrar, pois já pertence à crítica. Mas é que me surpreende um pouco a discussão sobre se um romance é ou não é romance. No entanto as mesmas pessoas que não o classificam de romance 
falam de seus personagens, discutem seus motivos, analisam suas soluções como possíveis ou não, aderem ou não aos sentimentos e pensamentos dos personagens (DM, p.270-1).

Em seguida, pergunta “O que é ficção?”, e reponde: “É, em suma, suponho, a criação de seres e acontecimentos que não existiram realmente, mas de tal modo poderiam existir que se tornam vivos. Mas que o livro obedeça a uma determinada forma de romance - sem nenhuma irritação, je m'en fiche". Mais à frente, sua pergunta é reformulada: "Por que não ficção, apenas por não contar uma série de fatos constituindo um enredo?". E esclarece: "Não é autobiográfico nem biográfico, e todos os pensamentos e emoções estão ligados a personagens que no livro em questão pensam e se comovem". Observando que para o romance no qual a "trajetória interior do personagem mal é abordada" se use a designação "romance social ou de aventuras", e para outro tipo de romance "se dê um outro epíteto", considera: "Enfim, problema apenas de classificação". Na conclusão, escreveu: "Mas é claro que A Paixão segundo G. H. é um romance" (DM, p.271).

O segundo texto, "Carta atrasada", foi publicado no dia 21 de fevereiro. Trata-se de uma carta dirigida a um autor, não identificado, de uma crítica à obra $A$ cidade sitiada. A autora destacou seu espanto por saber que a um crítico escapam os motivos maiores de seu livro:

Falam, ou melhor, antigamente falavam, tanto em minhas "palavras", em minhas "frases". Como se elas fossem verbais. No entanto nenhuma, mas nenhuma mesma, das palavras do livro foi - jogo. Cada uma delas quis essencialmente dizer alguma coisa. Continuo a considerar minhas palavras como sendo nuas (DM, p.273).

Sobre a personagem Lucrécia Neves, destacou importantes aspectos de sua construção:

personagem sem armas da inteligência, que aspira, no entanto, a essa espécie de integridade espiritual de um cavalo, que não "reparte" o que vê, que não tem uma “visão vocabular" ou mental das coisas, que não sente a necessidade de completar 
a impressão com a expressão - cavalo em que há o milagre de a impressão ser total - tal real - que nele a impressão já é a expressão (Idem).

O olhar do cavalo assim descrito se parece com o olhar que o narrador clariciano deseja para si. Em Perto do coração selvagem, Joana é alguém que nos diz que sabe quem ela é, mas não o sabe dizer, "porque no momento em que tento falar não só não exprimo o que sinto como o que sinto se transforma lentamente no que eu digo" (PCS, p.29). No final do romance, entre outras coisas sobre seu futuro, ela pensa:

[...] serei leve e vaga como o que se sente e não se entende, me ultrapassarei em ondas, ah, Deus, e que tudo venha e caia sobre mim mesma em certos momentos brancos porque basta me cumprir e então nada impedirá meu caminho até a morte-sem-medo, de qualquer luta ou descanso me levantarei forte e bela como um cavalo novo (PCS, p.224).

Outro aspecto ressaltado no texto "Carta atrasada" sobre o que a escritora pretendia que fosse percebido no romance $A$ cidade sitiada lembra o modo como Joana entende o ato criativo da visão:

Pretendi deixar dito também de como a visão - de como o modo de ver, o ponto de vista - altera a realidade, construindo-a. Uma casa não é construída apenas com pedra, cimento etc. $\mathrm{O}$ modo de olhar de um homem também a constrói. $\mathrm{O}$ modo de olhar dá o aspecto à realidade (DM, 273).

Por fim, sobre o "verbalismo" atribuído a sua linguagem, considerou que, "chamar de 'verbalismo' uma vontade dolorosa de aproximar o mais possível as palavras dos sentimentos - eis o que me espanta” (Ibid, p. 274).

O último texto, “O 'verdadeiro' romance", publicado no mês de agosto, assemelha-se ao texto "Romance", discutido no primeiro capítulo deste trabalho:

Bem sei o que é o chamado verdadeiro romance. No entanto, ao lê-lo, com suas tramas de fatos e descrições, sinto-me apenas aborrecida. E quando escrevo não é o clássico romance. No entanto é romance mesmo. Só que o que me guia ao escrevê-lo é sempre um senso de pesquisa e de descoberta. Não, não de sintaxe 
pela sintaxe em si, mas de sintaxe o mais possível se aproximando e me aproximando do que estou pensando na hora de escrever [...] (Ibid, p.306).

Ao escrever "o que me guia ao escrevê-lo é sempre um senso de pesquisa e de descoberta", a autora parece concordar com as palavras do crítico Antonio Candido sobre Perto do coração selvagem, o que não seria de estranhar, posto que, em carta a Clarice, Bluma Wainer, comentando o II Congresso Brasileiro de Escritores, fez referência a Antonio Candido com as seguintes palavras: "Você me pede para falar no Antonio Candido - já mandei dizer a você que tinha gostado muito dele e foi uma surpresa encontrar um rapaz de 29 anos" ${ }^{24}$.

Por meio dessas crônicas publicadas no Jornal do Brasil é possível percebermos que Clarice Lispector se interessou pelo que foi dito sobre sua obra, contribuindo para considerarmos o texto "Uma porta abstrata", possivelmente, uma resposta da escritora às críticas de que sua narrativa é abstrata. Usando a mesma palavra que a crítica usou, Clarice Lispector subverte o raciocínio, pois começa concordando que considera "fazer coisas abstratas como menos literária", mas, como ressaltou, concorda apenas "sob um certo ponto de vista". O que acaba revelando, por fim, é que, para ela, construir um romance, uma Vênus, uma porta, já tendo uma idéia pronta dessas coisas, é que é abstrato e, portanto, menos literário do que construir a obra obedecendo unicamente à idéia de que a forma só é dependente do conteúdo.

\section{"Os desastres de Sofia"}

Como outros textos que fazem parte da obra $A$ legião estrangeira, este conto também foi publicado originalmente na revista Senhor, em 1962.

A narradora situa-se no futuro em relação aos acontecimentos narrados. A voz narrativa da primeira pessoa, sendo a da mulher adulta que, às vezes, analisa o passado com distanciamento, com freqüência, apresenta o espaço e os fatos fixando-se no modo como foram vistos e sentidos em sua infância. Para Yudith Rosenbaum (1999, p.53), “o mergulho introspectivo se serve de uma estrutura mise-en-abîme, fazendo coexistir vários planos ficcionais para um mesmo sujeito".

O espaço ambiente é o espaço percebido no passado pela personagem criança. Ao reportar-se ao campo de recreio do colégio, a narradora, aproximando sua visão da

\footnotetext{
${ }^{54}$ Carta de Bluma Wainer a Clarice datada de 27 de novembro de 1947.
} 
época de criança da visão do esquilo e do cavalo, animais que têm visão, olfato e audição apurados, informa:

Era tão bonito para mim como seria para um esquilo ou um cavalo. Tinha árvores espalhadas, longas descidas e subidas e estendida relva. Não acabava nunca. Tudo ali era longe e grande, feito para pernas compridas de menina, com lugar para montes de tijolo e madeira de origem ignorada, para moitas de azedas begônias que nós comíamos, para o sol e sombra onde as abelhas faziam o mel. Lá cabia um ar imenso (LE, p.16).

Em Teorias da arte moderna há a seguinte passagem do texto "Como o cavalo vê o mundo?", de Franz Marc:

Existe idéia mais misteriosa para um artista do que imaginar como a natureza se reflete nos olhos de um animal? Como o cavalo vê o mundo? [...] Como é mesquinha, desalmada, a atitude por nós convencionada de dispormos animais em uma paisagem tal como a vemos, ao invés de nos aprofundarmos na alma do animal para tentarmos vislumbrar o modo como ele vê o mundo (MARC, Apud CHIPP, 1988, p.178).

A urgência de viver de Sofia-criança se parece com a de Joana. A narradora do conto comenta que "A verdade é que não sobrava tempo para estudar. As alegrias me ocupavam, ficar atenta me tomava dias e dias; havia os livros de história que eu lia roendo de paixão as unhas até o sabugo [...]” (LE, p.13). No romance, Joana-criança diz ao pai que não quer brincar nem estudar e a narradora, ao contar que Joana "vai para a mesinha dos livros", brincado com eles a distância, informa: "Podia-se ficar tardes inteiras pensado. Por exemplo: quem disse pela primeira vez assim: nunca?” (PCS, p. 23). Em uma passagem, como ocorre com Joana e outras personagens femininas de Clarice Lispector, Sofia é o correlato da galinha: "Fui para o recreio, onde fiquei sozinha com o prêmio inútil de ter sido a primeira, ciscando a terra, esperando impaciente pelos meninos que pouco a pouco começaram a surgir da sala” (LE, p.17. Grifo nosso).

A dimensão polissensorial do espaço, observada por Pierre Francastel ao discutir a nova figuração do espaço na pintura moderna, está presente na notação do espaço 
ambiente do conto. Um exemplo pode ser destacado no momento em que Sofia retorna à sala de aula durante o recreio e encontra-se pela primeira vez sozinha com o professor, que insistentemente ela vinha provocando. Após descrever a sensação de sentir-se olhada pelo professor, "sem o apoio cochichado da sala, sem a admiração que sua afoiteza provocava", ressaltando que "o olhar era uma pata macia e pesada sobre mim. Mas se a pata era suave, tolhia-me toda como a de um gato que sem pressa prende o rabo do rato" (p.18), a narradora, ao voltar-se para o espaço da sala, como já foi observado em relação à Joana-criança durante a conversa na casa do professor, permite percebermos que algo experimentado pela personagem no plano da consciência altera sua percepção do espaço ambiente, que passa a ser visto como se fosse pela primeira vez:

Nunca havia percebido como era comprida a sala de aula; só agora, ao lento passo do medo, eu via o seu tamanho real. Nem a minha falta de tempo me deixara perceber até então como eram austeras e altas as paredes; e duras, eu sentia a parede dura na palma da mão (LF, p.18).

Também aqui o espaço não é uma realidade dada a priori, mas algo percebido no plano da consciência pela personagem.

Diante da nova linguagem plástica, Francastel (1990, p.208) considerou que a figuração do homem é o ponto mais delicado: "Este, como o objeto, também perdeu seus atributos fixos - tão tranqüilizadores". Como observa, "também o homem é abordado pelos pintores como um objeto novo, que se revela sob aspectos imprevistos a partir do momento em que se deixa de considerar que existe uma figura-padrão fornecida pela estatuária clássica e mais ou menos vestida à moda da época" (p.208). Reportando-se à pintura Adão e Eva (1934) de Léger, Francastel observou que "o homem entra como um fragmento, tecido com o mesmo fio que as coisas e suscetível às mesmas desproporções" (p.209).

Com outras palavras, Anatol Rosenfeld (1996, p.85), ao refletir sobre o romance moderno, observou que o "desmascaramento" do espaço, tempo e causalidades é um processo que envolve o ser humano, posto que, "eliminado ou deformado na pintura, também se fragmenta ou decompõe no romance".

No conto, a narradora informa que nessa fase da sua infância "estava permanentemente ocupada em querer e não querer ser o que era, não me decidia por 
qual de mim, toda eu é que não podia; ter nascido era cheio de erros a corrigir”. A narrativa nos dá a ver diferentes Sofias. Quando a narradora informa que "só tinha tempo de crescer", o que "fazia para todos os lados com uma falta de graça que mais parecia o resultado de uma falta de cálculo", é com esta falta de cálculo percebida em seu corpo que a narradora "pinta-nos" sua imagem com palavras: "as pernas não combinavam com os olhos, e a boca era emocionada enquanto as mãos se esgalhavam sujas" (LE, p.13). Ao reportar-se a um retrato dessa época, a descrição é menos confusa: "Uma menina bem plantada, selvagem e suave, com os olhos pensativos embaixo da franja pesada". Adiantando quatro anos em relação ao tempo inicial do conto, refere-se à imagem que passou a ter aos treze anos: "Foi pena o professor não ter chegado a ver aquilo em que quatro anos depois inesperadamente eu me tornara: aos treze anos, de mãos limpas, banho tomado, toda composta e bonitinha, ele me teria visto como um cromo de Natal à varanda de um sobrado" (LE, p.14). Ela se imagina um "desenho" que seria visto pelo professor. Esta passagem da narrativa informa a transformação da menina e adianta-nos a morte do professor, anunciada aos gritos por um ex-amiguinho de Sofia situado embaixo da calçada enquanto ela se encontrava na varanda do sobrado. Sua reação ao saber da notícia encerra uma outra imagem da menina: "E branca, de olhos muito abertos, eu olhara a rua vertiginosa a meus pés. Minha compostura quebrada como a de uma boneca partida" (LE, p.14). Ela se "retrata" fragmentada diante da notícia da morte do professor.

A narrativa concentra-se na época dos seus nove anos, quando provocava o professor, mais especificamente, no dia em que escreveu a composição solicitada por ele e chamou-lhe, finalmente, a atenção. As descrições mais inusitadas de sua imagem são as que se referem ao momento do confronto da menina com o olhar do professor depois que ele leu sua composição. Primeiramente, a narradora descreve como atravessou o recreio em direção à sala de aula: "Toda molhada de suor, vermelha de uma felicidade irrepresável que se fosse em casa me valeria uns tapas - voei em direção à sala de aula" (p.18). Mas, ao perceber o olhar do professor, a sensação que teve do próprio rosto foi a de que ele se reduziu a um sorriso: "Comecei a costear a parede de olhos baixos, prendendo-me toda a meu sorriso, único traço de um rosto que já perdera o contorno" (p.18). Foi nesse instante que ela percebeu a sala de aula como nunca tinha percebido antes. A alusão às sensações que experimentou no corpo durante esse instante de silêncio continua. Ela imagina-se como se estivesse refletida em um espelho: "Foi num arrepio que me adivinhei de repente como num espelho: uma coisa úmida se 
encostando à parede, avançando devagar na ponta dos pés, e com um sorriso cada vez mais intenso". Com a permanência do confronto, também o sorriso se desfaz: "Meu sorriso, tudo o que sobrara de um rosto, também se apagara. Eu era dois pés endurecidos no chão e um coração que de tão vazio parecia morrer de sede" (LE, p. 18-9). O modo como suas imagens são apreendidas no presente pela narradora presentifica as sensações vividas na infância, enfatizando 0 modo como 0 acontecimento foi sentido.

Em relação à pintura moderna, como destacamos anteriormente, Francastel observou que os grandes mistérios da natureza cederam lugar aos detalhes, "e os mais próximos, finalmente, os que dizem respeito não ao objeto da sensação, mas à sensação em si mesma, apreendida, por assim dizer, em estado bruto do órgão da percepção". Na narrativa, esse aspecto culmina na ênfase dada ao instante, o que, para Auerbach, torna visível a pletora de realidade e a profundidade vital de qualquer instante ao qual nos entregamos sem preconceito.

No conto de Clarice Lispector, o ponto culminante é o instante em que a personagem e o professor se encontram sozinhos na sala de aula e algo se torna visível para Sofia-criança, embora ela não saiba especificá-lo com as palavras: "E meu estômago se encheu de uma água de náusea. Não sei contar" (LE, p.22). O conto narra o acontecimento, mas o que importou não foi o acontecimento em si, e sim esse algo vislumbrado em segredo, fazendo-nos perceber a profundidade vital do instante em que nem mesmo a personagem soube com certeza o que viu. O modo de torná-lo visível pela linguagem é recuperando não o visto, mas o modo como foi visto: "O que vi, vi tão de perto que não sei o que vi. Como se meu olho curioso se tivesse colado ao buraco da fechadura e em choque deparasse do outro lado com outro olho colado me olhando. Eu vi dentro de um olho. O que era incompreensível como um olho" (p.22-3). O que viu apontou para ela mesma.

A consciência de que não sabe contar perpassa a obra da escritora Clarice Lispector. Não saber faz parte de sua técnica humilde, referida no texto "Escrever, humildade, técnica". Não saber, porém, é um aspecto positivo para esta escritora consciente de que apenas se aproximando humildemente a coisa não escapa totalmente. Sua narrativa resulta de uma luta para se aproximar do lado sensorial das coisas, como observou Francis Bacon em relação à pintura.

Quando o professor a olha sem seus óculos, a personagem, também olhando-o atentamente, observando que "as inúmeras pestanas pareciam duas baratas doces", 
considera: "E eu não soube como existir na frente de um homem". A personagem encosta-se à parede como se quisesse desaparecer confundindo-se com esta: "Devagar, para ele não perceber, recuei as costas até encontrar atrás delas a parede, e depois a cabeça recuou até não ter mais para onde ir. Daquela parede onde eu me engastara toda, furtivamente, olhei-o" (p.22).

Este instante de silêncio, cheio de sensações, para a personagem, começa a ser quebrado quando o professor dirige-lhe a palavra, mas aí, ela começa a perceber que, diferentemente do que esperava, ele não estava com raiva dela. A reação que sua composição causou fora outra, e alguma coisa é percebida pela personagem, mas ela diz não saber contar. Visualmente, ela viu no rosto do professor algo que se parece com um sorriso, mas a narrativa alude ao que este sorriso diz mudamente e que a personagem percebe, sem destruir a dimensão encantatória do acontecimento vivido.

Para o crítico Benedito Nunes (1989, p.89), este confronto corresponde a um momento privilegiado de descortínio no qual "Sofia compreende a sua vocação de escritora e o destino intranqüilo que o dom da palavra lhe impunha". Sua vocação de escritora, para nós, está relacionada com sua vocação de desenhista com palavras.

A história que o professor contou foi narrada no conto:

Um homem muito pobre sonhara que descobrira um tesouro e ficara rico; acordando, arrumara sua trouxa, saira em busca do tesouro; andara o mundo inteiro e continuava sem achar o tesouro; cansado, voltava para a sua pobre, pobre casinha; e como não tinha o que comer, começara a plantar no seu pobre quintal; tanto plantara, tanto colhera, tanto começara a vender que terminara ficando rico (LE, p.15).

$\mathrm{Na}$ história do professor está implícita a lógica do capitalismo, sistema caracterizado pela propriedade privada dos meios de produção e liberdade de iniciativa do homem. A personagem é o dono de uma pobre casinha e, por iniciativa própria, planta, colhe e vende até ficar rico.

A história que Sofia compôs com suas próprias palavras, a pedido do professor, não é narrada. A narradora informa que já não se lembra, "não consigo imaginar com que palavras de criança teria eu exposto um sentimento simples mas que se torna pensamento complicado". Porém, a narradora reflete sobre o sentido do que deve ter escrito: 
Suponho que, arbitrariamente contrariando o sentido real da história, eu de algum modo já me prometia por escrito que o ócio, mais que o trabalho, me daria as grandes recompensas gratuitas, as únicas que eu aspirava. É possível também que já então meu tema de vida fosse a irrazoável esperança, e que eu já tivesse iniciado a minha grande obstinação: eu daria tudo o que era meu por nada, mas queria que tudo me fosse dado por nada. Ao contrário do trabalhador da história, na composição eu sacudia dos ombros todos os deveres e dela saía livre e pobre, e com um tesouro na mão (LE, p.17).

As palavras de Sofia aludem a outra riqueza. Sua grande obstinação, dar e receber sem esperar recompensas, é liberdade. Seu tesouro é diferente do tesouro da personagem da história do professor: não tem preço e, por isso, como a arte, não deve caber na lógica do mercado. A esse respeito, o crítico Rodrigo Naves (2007, p.508), observando que "a cadeira de Van Gogh não pode ser levada de lá para cá justamente porque estabeleceu vínculos que a fizeram dependente de uma trama de relações infinitamente superior à vontade que a moveria de um canto para outro", considera que “a forma artística reside na construção desse outro complexo de relações que remete ao mundo que conhecemos, ainda que lhe voltemos as costas". Daí, discordando que essa outra estrutura decorra da imaginação ou de fabulações misteriosas, Naves ressalta:

Raramente se requer maior contato com o mundo. A forma artística tira sua força de momentos que experimentamos de maneira falha na realidade e aos quais procuramos restituir sua inteireza. Por isso a arte nos faz sentir melhores do que somos e por isso consideramos a atividade artística uma forma superior de trabalho (NAVES, 2007, p.508).

Os narradores claricianos não eliminam a maneira falha pela qual se apercebem das coisas do mundo e têm consciência da forma superior de trabalho à qual o artista se entrega. A narradora Sofia considera que, na composição que escreveu, sacudiu dos ombros os deveres e saiu livre, pobre e com um tesouro na mão.

Sofia-adulta, narradora, já sabe o que se passou depois que sua composição foi lida pelo professor: "Eu ia receber de volta em pleno rosto a bola de mundo que eu mesma lhe jogara e que nem por isso me era conhecida. Ia receber de volta uma 
realidade que não teria existido se eu não a tivesse temerariamente adivinhado e assim lhe dado vida" (LE, p.20). O conto narra o instante em que Sofia-criança está diante desse desvelar.

Lembrando do conceito de espaço em obra, de Alberto Tassinari, observamos que a narradora deste conto expõe sinais do fazer, permitindo-nos considerar que, no espaço da escritura, a narrativa deixa ver o modo singular de Sofia construir a narrativa. A primeira parte em que isso acontece é na passagem abaixo:

As palavras me antecedem e ultrapassam, elas me tentam e me modificam, e se não tomo cuidado será tarde demais: as coisas serão ditas sem eu as ter dito. $\mathrm{Ou}$ pelo menos, não era apenas isso. Meu enleio vem de que um tapete é feito de tantos fios que não posso me resignar a seguir um fio só; meu enredamento vem de que uma história é feita de muitas histórias. E nem todas posso contar - uma palavra mais verdadeira poderia de eco em eco fazer desabar pelo despenhadeiro as minhas altas geleiras. Assim, pois, não falarei mais no sorvedouro que havia em mim enquanto eu devaneava antes de adormecer. Senão eu mesma terminarei pensando que era apenas essa macia voragem o que me impelia para ele (LE, p. 11. Grifo nosso).

Um dos fios desse tapete que é o texto é o devaneio, a vida imaginada que mantinha com o professor antes de adormecer: "Minha vida com o professor era invisível". Outro fios encontram-se nos livros de história que a personagem leu, como informa "roendo as unhas até o sabugo". A esse respeito, Benedito Nunes (1989, p.90), ao analisar o conto, tratou o título como um dos índices de paródia, observando em nota explicativa que Clarice Lispector adota o título que tomou em português Les malheurs de Sophie, parte da obra edificante da Condessa de Ségur, acrescentando que "às travessuras da irrequieta e inocente Sophie desse livro, no ambiente da alta burguesia fin-de-siècle, não falta uma certa malignidade infantil que o conto de Lispector revela e acentua na sua personagem homônima". Outro índice apontado pelo crítico aparece no final do conto, "o lobo da história de Chapeuzinho Vermelho, assimilado ao lobo do homem".

A "realidade advinhada" é mais um fio. A realidade tornada invenção quando contada, por isso, no espaço da escritura, reportando-se à própria história que está narrando, informa: "Foi talvez por tudo o que contei, misturado e em conjunto, que 
escrevi a composição que o professor mandara, ponto de desenlace dessa história e começo de outras" (LE, p.14. Grifo nosso).

A composição de Sofia é o ponto de desenlace da história porque é por meio dela que a menina consegue chamar a atenção do professor, coisa que vinha tentando fazer em sala de aula sem sucesso, e descobrir seu próprio tesouro. Ao escrever a mesma história que o professor contara, mas optando pela moral oposta, diferentemente do que imaginara, ela não desperta no professor de ombros caídos a cólera, antes, libera algo parecido com a esperança, a alegria, um sorriso que ele não tinha. Ao perceber uma reação inesperada no leitor, descobre o seu tesouro, como observou Nunes: compreende sua vocação de escritora.

Sobre a composição que escreveu para o professor, Sofia diz: "A história que eu transcrevera em minhas próprias palavras era igual à que ele contara”. Mais à frente informa: "mas levianamente concluíra pela moral oposta: alguma coisa sobre o tesouro que se disfarça, que está onde menos se espera, que é só descobrir" (p.16-7). Esta história é mais um fio do tapete, pois o conto é a história desse tesouro disfarçado descoberto pela narradora.

Os momentos de descoberta da menina são narrados como uma corrida dentro de si: "Quando enfim me dei conta de estar bem longe da órbita do professor, sofreei exausta a corrida [...]. Eu ainda tinha muito mais corrida dentro de mim [...]” (LE, p.26). Mais à frente a narradora diz que não sabe o que ela, quando menina, entendeu, e que até hoje não sabe o que viu:

E não sei o que na hora entendi. Mas assim como por um instante no professor eu vira com aterrorizado fascínio o mundo - e mesmo agora ainda não sei o que vi assim eu nos entendi, e nunca saberei o que entendi. Nunca saberei o que eu entendo. $\mathrm{O}$ que quer que eu tenha entendido no parque foi, com um choque de doçura, entendido pela minha ignorância. Ignorância que ali em pé - numa solidão sem dor, não menor que a das árvores - eu recuperava inteira, a ignorância e sua verdade incompreensível (LE, p.28. Grifo nosso).

No presente, a narradora do conto entende ("Nunca saberei o que hoje entendo"), mas continua não sabendo dizer o que viu, embora consiga nos dizer que o que viu no professor, anunciou-lhe algo sobre si mesma. Sua imagem é a de virgem anunciada: 
Como uma virgem anunciada, sim. Por ele me ter permitido que eu o fizesse enfim sorrir, por isso ele me anunciara. Ele acabara de me transformar em mais do que o rei da Criação: fizera de mim a mulher do rei da Criação. Pois logo a mim, tão cheia de garras e sonhos, coubera arrancar de seu coração a flecha farpada. De chofre explicava-se para que eu nascera com a mão dura, e para que eu nascera sem nojo da dor (Idem).

O último parágrafo do conto inicia-se com reticências e tem um primeiro final para a história: "Foi assim que no grande parque do colégio lentamente comecei a aprender a ser amada, suportando o sacrifício de não merecer, apenas para suavizar a dor de quem não ama”. Porém, outro final é dado logo em seguida, permitindo-nos perceber que o conto é também a história de um dos motivos que levou a narradora a se tornar escritora: "Não, esse foi somente um dos motivos. É que os outros fazem outras histórias. Em algumas foi de meu coração que outras garras cheias de duro amor arrancaram a flecha, e sem nojo de meu grito" (LE, p.29).

Se compararmos a história que o professor contou com o que Sofia se recorda sobre sua própria composição, poderemos perceber com que garra cheia de duro amor a Sofia-criança arrancou a flecha do coração do homem.

\section{"O ovo e a galinha"}

$\mathrm{Na}$ comunicação "Literatura e magia", que a escritora preparou para o Primeiro Congresso Mundial de Bruxaria, realizado em Bogotá, em 1975, mas acabou não lendo, reportando-se ao "O ovo e a galinha", escreveu: "Este texto é misterioso até para mim mesma e tem uma simbologia secreta".

O volume Outros escritos, entre textos inéditos da escritora, apresenta duas versões do texto "Literatura e magia", mas, consultado o arquivo da escritora na Fundação Casa de Rui Barbosa, encontramos outra versão da comunicação, reunida ao texto "A inspiração é uma espécie de mágica", com o título "Introdução". Neste texto, Clarice Lispector dirige-se ao público com as seguintes palavras: "Eu peço a vocês para não ouvirem só com o raciocínio porque, se vocês tentarem apenas raciocinar, tudo o que vai ser dito escapará do entendimento. Se uma dúzia de ouvintes sentir o meu texto já me darei por satisfeita. E agora por obséquio ouçam ' $O$ ovo e a galinha'",55.

\footnotetext{
${ }^{55}$ Texto manuscrito, catalogado no Inventário do Arquivo Clarice Lispector da Fundação Casa de Rui Barbosa como Produção Intelectual (CL/pi-46).
} 
Suas palavras convidam o público a uma experiência perceptiva com o texto, solicitando um ouvinte tão capaz quanto o espectador de Kandinsky de "sentir a vida interior do quadro, deixar que ela atue diretamente sobre ele".

Considerando que a compreensão real da arte depende da apreciação da natureza e da utilização do simbolismo, e que o simbolismo, tanto quanto a experiência direta do mundo externo, é uma forma de funcionamento do espírito humano, Herbert Read (s/d) discute a época moderna na arte a partir das aspirações de três artistas: Cézanne, Gauguin e Van Gogh, descrevendo a aspiração de Cézanne como a de representação do real (Realismo); a de Gauguin como de criação da beleza (Simbolismo), e a de Van Gogh, provisoriamente, como a expressão da emoção (Expressionismo). A escolha dos nomes destes três artistas torna-se compreensiva se lembrarmos, por exemplo, que, para Francastel, os artistas contemporâneos partiram das experiências desses três, ou que, para Mário Pedrosa (2000, p148), no ensaio Panorama da pintura moderna, publicado originalmente em 1951, Gauguin, Cézanne e Van Gogh transpuseram os umbrais do século XIX, com mensagem que "pertence já às primeiras gerações do Novecentos".

Herbert Read estabelece uma distinção entre o artista imagista e o artista simbolista a partir de uma passagem do livro Symbolism: its meaning and effect (1928), de Whitehead:

Olhamos, vemos uma forma colorida à nossa frente e dizemos - é uma cadeira. Mas a única coisa que vimos foi a forma colorida. Talvez o artista não devesse precipitar-se para a noção de cadeira, mas ficar antes na contemplação da beleza da forma. Mas os que não são artistas têm tendência, especialmente se estão cansados, para passar da percepção da forma colorida para a apreciação da cadeira, no sentido do uso da emoção ou do pensamento. Podemos explicar facilmente esta passagem se nos referirmos a uma seqüência de inferências lógicas difíceis, através das quais, tomando em consideração as nossas experiências anteriores de várias formas e várias cores, tiramos a conclusão possível de que estamos perante uma cadeira (WHITEHEAD, Apud READ, s/d, p.21).

Para Read, a passagem acima ilustra claramente a diferença entre a experiência perceptiva (a percepção imediata de uma imagem) e o uso de um símbolo (a imagem mais as associações mentais). Com isso, estabelece a diferença entre o artista imagista, capaz "de realizar e de reter a imagem como vivência perceptiva", e o artista simbolista, 
que "abandona-se livremente à atividade simbólica" (p.22). Para ele, são duas vias abertas ao artista. Na primeira, situa Cézanne, e na segunda, Gauguin, observando que na paisagem de Cézanne "não há nada senão o contato directo do olho com a natureza, e a 'composição' é determinada pelo que acontece 'dentro do olho' - a seleção automática de um ponto focal, limitação dos contornos, subordinação dos detalhes e cores à lei do conjunto" (p.31); em Gauguin, "a forma não devia ser encontrada na natureza mas sim na imaginação" (p.32).

A oposição Cézanne - Gauguin, mais radical no ensaio de Read, é atenuada por Giulio Carlo Argan (1992) ao considerar que Cézanne "não aceita a pintura puramente visual de seus amigos impressionistas" (p.110) e, além disso, entender o sentido das viagens de Gauguin para a pintura do seguinte modo:

Para um pintor que percorre o caminho aberto pelo Impressionismo, é muito importante o ambiente concreto em que opera, a fonte de suas 'sensações'. Gauguin não podia trabalhar num terreno já explorado pelas pesquisas opostas de Cézanne e Van Gogh, o Sul da França. Com efeito, em sua primeira evasão dirige-se para Bretanha, na França do Norte. Seu entusiasmo pela natureza e povos de terras distantes não é uma retomada do exotismo romântico: na Martinica ou na Polinésia não procura algo novo ou diferente, mas a realidade profunda do próprio ser. Não explora o mundo em busca de sensações novas, explora a si mesmo para descobrir as origens, os motivos remotos de suas sensações (Ibid, 1992, p.130).

No modo como Argan entende a busca de Gauguin, pode-se dizer que o uso do símbolo não está dissociado da experiência perceptiva, e nesse sentido uma passagem do ensaio "O olho e o espírito", de Merleau-Ponty, nos é bastante elucidativa:

O pintor, qualquer que seja, enquanto pinta, pratica uma teoria mágica da visão. Ele precisa admitir que as coisas entram nele ou que, segundo o dilema sarcástico de Malebranche, o espírito sai pelos olhos para passear pelas coisas, uma vez que não cessa de ajustar sobre elas sua vidência. (Nada muda se ele não pinta a partir do motivo: ele pinta, em todo o caso porque viu, porque o mundo, ao menos uma vez, gravou dentro dele as cifras do visível) (MERLEAU-PONTY, 2004, p.20). 
Pierre Francastel, para quem a figuração espacial moderna é uma "figuração psicofisiológica e não mais óptica no sentido euclidiano do termo", considerou que Gauguin, sem dúvida, abriu amplos caminhos para o imaginário, mas

não é evidente que esse imaginário seja desprovido de qualidades espaciais. Pelo contrário, estou convencido de que Gauguin trouxe, simultaneamente, aos tempos modernos uma intuição das riquezas infinitas do mundo e dos meios práticos para inventariá-las. Eles nos fornecem um método para renovar, para lá da figuração dos episódios, o sistema geral de visualização, na tela plástica móvel, de nossas viagens mais ousadas através dos mundos imensos do entrevisto (FRANCASTEL, 1990, 176).

No conto "O ovo e a galinha", a percepção imediata de uma imagem e as associações mentais não se apresentam como duas vias inconfundíveis, porém, o olhar que reconhece o ovo do café-da-manhã dá lugar ao olhar que inventa o ovo imaginado. A personagem, além de preparar o café-da-manhã, prepara o texto. O conto narra a atividade externa (preparar o ovo) e interna (pensar o ovo).

A narrativa começa situando a ação no tempo e no espaço: "DE MANHÃ na cozinha sobre a mesa vejo o ovo". Ao ver o ovo, o olhar da personagem não exerce apenas a visão prática, que, como escreveu Roger Fry (2002, p.78) "cessa no instante em que cumpriu sua visão biológica", exerce a visão criativa, aquela na qual, como ressaltou o crítico, "os objetos tendem a desaparecer enquanto tais, perdendo as distinções que os individualizam e assumindo, como tantos outros fragmentos, seus lugares no mosaico completo da visão" (p.81).

A primeira consideração da protagonista sobre ver o ovo é quanto à impossibilidade da visão: ver o ovo como um objeto nomeado, é reconhecê-lo ("Ver o ovo nunca se mantém no presente: mal vejo um ovo e já se torna ter visto um ovo há milênio"). Ver o nomeado não descortina nada, por isso ressalta: "Olhar curto e indivisível; se é que há pensamento; não há; há o ovo. - Olhar é o necessário instrumento que, depois de usado, jogarei fora. Ficarei com o ovo. - O ovo não tem um si-mesmo. Individualmente ele não existe" (LE, p.55).

No primeiro romance da escritora, Perto do coração selvagem (1943), Joana, protagonista considerada pelo crítico Sérgio Milliet "de uma sensibilidade complexa e um poder expressivo inato que frisa a magia incantatória”, define o pensamento criativo 
como o ato que dá existência às coisas. Ver compara-se ao instante em que o pensamento dá existência às coisas por surpreender o símbolo das coisas nas próprias coisas.

José Miguel Wisnik (1988, p.287) considerou o conto "O ovo e a galinha" como "verdadeiro tratado poético sobre o olhar", que "não se limita a comentar as vicissitudes do olho e do pensamento diante da coisa, mas cifra na própria escolha do objeto uma espécie de circularidade enigmática do olhar". Após ressaltar a simbologia da palavra ovo, destacou que "mesmo assim, prototípico, alegórico, marca sublimada e apagada de um real que hesita entre a consciência e o inconsciente, o eu e o Outro, o ovo não deixa de ser, no conto de Clarice Lispector, o ovo doméstico, cotidiano". Esta nitidez do ovo doméstico ressaltada nas palavras de Wisnik, e, no conto, pelas muitas vezes em que a protagonista aponta para o olhar dirigido ao ovo sobre a mesa, só contribui para tornar ainda mais admirável o processo de criação elaborado pela imaginação e aludido pela linguagem. O ovo, na literatura de Clarice Lispector, é palavra que escapa do entendimento, se se busca compreendê-la fora da obra. Em outros termos, Benedito Nunes observou que, mesmo tendo nome,

sendo 'ovo', aquilo de que repetidamente se fala, passível de receber outros nomes, será até o fim do conto excedentário aos símbolos destinados a circunscrevê-lo, reaparecendo sempre, objeto visível de significado indizível, através dos elos que compõem a teia lingüística das definições que o transportam (NUNES, 1989, p.92-3).

A circularidade se manifesta no movimento do olhar da protagonista que parte do visto, torna-o impossível pelo pensamento criativo (“O ovo não existe mais. Como a luz da estrela já morta, o ovo propriamente dito não existe mais") e retorna, com freqüência, ao visto ("De repente olho o ovo na cozinha e só vejo nele a comida") até que, sem saber, um novo ovo seja feito. E se manifesta, ainda, na obra da escritora, nas muitas vezes em que ovo e galinha reaparecem em seus textos.

Curiosamente, no conto “Amor”, já referido em outro capítulo deste trabalho, depois que "o embrulho dos ovos foi jogado fora da rede", Ana passou a perceber o mundo como "uma estranha música" que "recomeçava ao redor". A partir do momento em que se deu a quebra dos ovos, o mundo, para Ana, deixou de ser uma forma em equilíbrio: 
Vários anos ruíam, as gemas amarelas escorriam. Expulsa de seus próprios dias, parecia-lhe que as pessoas na rua eram periclitantes, que se mantinham por um mínimo equilíbrio à tona da escuridão - e por um momento a falta de sentido deixava-as tão livres que elas não sabiam para onde ir. Perceber uma ausência de lei foi tão súbito que Ana se agarrou ao banco da frente, como se pudesse cair do bonde, como se as coisas pudessem ser revertidas com a mesma calma com que não o eram (LF, p.27).

Em "O ovo e a galinha", vemos o ovo da cozinha transformar-se em outro ovo: “Olho o ovo na cozinha com atenção superficial para não quebrá-lo. Tomo maior cuidado de não entendê-lo. Sendo impossível entendê-lo, sei que se eu entender é porque estou errando. Entender é a prova do erro" (LE, p.56). Esta passagem aponta para o ovo da cozinha em processo de transformação, permitindo-nos observar a protagonista expondo sua consciência desse instante de criação-transformação que está realizando, por isso sua atenção/cuidado para não quebrar/entender o ovo re-criado.

No texto "Paul Klee", o enunciador aborda o quadro Paysage aux oiseaux jaunes refletindo sobre a realização do seguinte modo: "É que a possibilidade que é verdadeiramente realizada, não é para ser entendida. E à medida que a pessoa quiser explicar, ela estará perdendo a coragem, ela já estará pedindo; Paysage aux oiseaux jaunes não pede”. Clarice Lispector entendeu, como escreveu Argan (1992, p.272), que Paul Klee "não traduz a imagem em conceito, o que equivaleria a destruí-la; limita-se a torná-la visível, pois a percepção já é consciência”.

Kandinsky (2000, p.167), em A gramática da criação, coletânea de escritos que foi reunida ao Do espiritual na arte, ao considerar que "não existe mal maior do que a compreensão da arte", deixou claro que a explicação que recusa é aquela em que "uma palavra (uma etiqueta) toma o lugar de uma obra viva", pois, destaca: "Fica, pois, evidente que a explicação enquanto tal não nos pode aproximar da obra de arte. A obra de arte é o espírito que, através da forma, fala, se manifesta, exerce uma influência fecunda".

O conhecimento de que para Clarice Lispector o pensamento dos artistas modernos sobre a comunicabilidade da forma não era algo estranho, muito pelo contrário, pode ser observado no estudo de Carlos Mendes de Sousa (2000, p.277), ao considerar que "é evidente que um vastíssimo suporte de leituras, feitas sobretudo nos 
anos em que Clarice esteve fora do país, sustenta uma extraordinária base de apoio ao modo como ela se encontrou nas intuições e inspirações". Entre os livros que pertenceram à escritora, Sousa cita a obra Degas, dança e desenho, de Paul Valery, sublinhada na seguinte passagem: "Il nous enseigne à découvrir qu'une forme est féconde em ideés" (Ele nos ensina a descobrir que uma forma é fecunda em idéias. Tradução nossa). Além disso, como vimos, o romance Perto do coração selvagem tem duas passagens em que a protagonista Joana pensa: "o movimento explica a forma". E o texto "Seco estudo de cavalos", da obra Onde estivestes de noite (1974), no fragmento "Forma", traz explícita a frase "sua forma fala". Nesse sentido, Clarice não só entendeu que a forma comunica, como trabalha a linguagem para que a forma fale.

A afinidade com Chagall, declarada pela escritora, pode ser buscada em algumas passagens deste conto, principalmente se observarmos junto com Argan que

Chagall se mantém mais próximo ao plano da experiência sensorial, que para ele é imediatamente contíguo ao plano da psique. Antes não era possível tornar visível a realidade psíquica profunda, porque a tela sensorial estava preventivamente organizada pela razão: via-se de acordo com uma lógica pré-construída. Agora, não mais: o Impressionismo com tudo o que veio a seguir, desmontou essa superestrutura racional. $\mathrm{O}$ ver é um fato físico, mas a realidade física não está separada da realidade psíquica. Chagall não tem qualquer reserva em expor suas imagens fantásticas; pode-se até mesmo dizer que as 'representa' no sentido teatral do termo, fazendo-as mover-se num palco imaginário, como um diretor faria com seus atores (ARGAN, 1992, p.473).

Para o quadro “À la Russie, aux ânes et aux autres” (1911), Argan usou a expressão "fabulação visual”. Para o conto de Clarice, Benedito Nunes (1989, p.92) usou a expressão "fantasia verbal onírica". O pintor criou, como escreveu Argan, "uma espécie de perspectiva arbitrária, um espaço impossível, onde se torna normal o absurdo da vaca no telhado". A escritora criou, a partir de uma cena trivial, ovo na mesa da cozinha, ovo no espaço, totalmente liberto do cotidiano, sem pretender entender suas imagens. Para o quadro de Chagall, Argan observou também que

há, na raiz, uma simbologia das cores; qual é o símbolo não importa saber, ou melhor, não se deve saber, pois do contrário o encanto seria rompido. Ou melhor, 
sabe-se no inconsciente: o símbolo é a linguagem do inconsciente, como a lógica é a da consciência; e o símbolo deve permanecer inconsciente e hermético, justamente porque é ilógico em si, não se podendo admitir logicamente que o mesmo signo signifique duas coisas diferentes (Ibid, p.473).

A contribuição do grande talento de Chagall para a história da pintura moderna, na concepção de Argan, foi "a descoberta de que a fonte da linguagem, inclusive da linguagem visual, é a imaginação, não a lógica, mas que a imaginação, tal como a lógica, possui uma estrutura própria e cumpre uma função 'construtiva'” (p.473).

Como observamos no começo desta leitura, Clarice Lispector escreveu: "este texto é misterioso até para mim mesma e tem uma simbologia secreta”. Porém, não podemos deixar de considerar o caráter simbólico da palavra ovo, tanto isoladamente, posto que, como se pode observar no Dicionário dos Símbolos, de Chevalier e Gheerbrant (2006, p.672), “o ovo, considerado como aquele que contém o germe e a partir do qual se desenvolverá a manifestação, é um símbolo universal e explica-se por si mesmo", quanto em frases como "ao ovo dedico a nação chinesa", pois de acordo com o mesmo Dicionário dos Símbolos, "nas tradições chinesas, antes de qualquer distinção entre o céu e a terra, o próprio caos tinha a aparência de um ovo de galinha” (p.673). Mesmo observando esses sentidos simbólicos do ovo, no texto, o simbolismo do ovo é fugidio. Este ovo, como informa a personagem, "é um esquivo". Ao leitor são dadas alusões e a certeza de que "o ovo é uma exteriorização".

Francastel (1990, p.109), discordando da concepção de que as pesquisas do Quattrocento sejam baseadas na abordagem voluntária de um modo de figuração privilegiada da natureza, não nega que, "ainda hoje, o sistema ilusionista do Renascimento satisfaça a determinados hábitos intelectuais muito cômodos ao espírito". Ou seja, não nega o condicionamento do olhar.

Quando a protagonista ressalta a importância de esquecer o ovo, pensamos que, primeiro, ela viu o ovo, mas a visão criativa só se realiza depois que o esquece ("ovo visto, ovo perdido"). A protagonista do conto tem consciência de que é preciso esquecer aquilo que o olhar convencional deixa ver para que assim o ovo se torne um visívelinvisível no espaço da arte. Em sua conferência sobre vanguarda e literatura, de 1963, Clarice Lispector escreveu: "Ver é inventar".

No "Fundo de gaveta", o texto "Lembrar-se" traz a seguinte definição do que é escrever: "Escrever é tantas vezes lembrar-se do que nunca existiu. Como conseguirei 
saber do que nem ao menos sei? assim: com se me lembrasse. Com um esforço de 'memória', como se eu nunca tivesse nascido. Nunca nasci, nunca vivi: mas eu me lembro, e a lembrança é em carne viva" (LE, p.143-4). Nesse sentido, escrever é inventar, mas implica a lembrança daquilo que se sente e não se sabe.

Herbert Read, após citar a passagem do livro Symbolism: its meaning and effect (1928), de Whitehead, considerou que, partindo da distinção entre uma experiência perceptiva e o uso do símbolo, "poderíamos compreender Van Gogh quando dizia que 'um pintor é um homem demasiado absorvido pelo que vêem os seus olhos para poder ter o domínio do resto de sua vida". No conto de Clarice Lispector, a protagonista não pretende desprender-se totalmente do vivido, pois, como ressalta: "A aura dos meus dedos é que vê o ovo. Não toco nele. - Mas dedicar-me à visão do ovo seria morrer para a vida mundana, e eu preciso da gema e da clara".

A galinha, a que cria o ovo, é definida em função de sua relação com o ovo:

E a galinha? O ovo é o grande sacrifício da galinha. O ovo é a cruz que a galinha carrega na vida. O ovo é o sonho inatingível da galinha. A galinha ama o ovo. Ela não sabe que existe o ovo. Se soubesse que tem em si um ovo, ela se salvaria? Se soubesse que tem em si o ovo, perderia o estado de galinha. Ser uma galinha é a sobrevivência da galinha. Sobreviver é a salvação. Pois parece que viver não existe. Viver leva à morte. Então o que a galinha faz é estar permanentemente sobrevivendo. Sobreviver chama-se manter luta contra a vida que é mortal. Ser uma galinha é isso. A galinha tem o ar constrangido (LE, 1964, p.58. Grifo nosso).

Ser galinha é um "estado" no qual o sujeito não sabe que já tem em si o objeto. Em sua relação com ovo não é possível falar em sujeito e objeto:

É necessário que a galinha não saiba que tem o ovo. Senão ela se salvaria como galinha, o que também não é garantido, mas perderia o ovo. Então ela não sabe. Para que o ovo use a galinha é que a galinha existe. Ela era só para se cumprir, mas gostou. O desarvoramento da galinha vem disso: gostar não fazia parte de nascer. Gostar de estar vivo dói - Quanto a quem veio antes, foi o ovo que achou a galinha. A galinha não foi sequer chamada. A galinha é diretamente uma escolhida (LE, p.58-9). 
Embaralham-se os papéis entre o sujeito e objeto: "foi o ovo que achou a galinha", ela "é diretamente uma escolhida". Continuando, a personagem pensa: "A galinha vive como em sonho. Não tem senso de realidade. Todo susto da galinha é porque estão sempre interrompendo o seu devaneio. A galinha é um grande sono". A galinha, assim descrita, assemelha-se à protagonista que, como informa, "Mergulhada no sonho preparo o café-da-manhã. Sem nenhum senso de realidade".

Enquanto prepara o ovo do café-da-manhã e pensa o ovo, há duas passagens bastante obscuras para nós leitores, que correspondem aos instantes em que a personagem está inteiramente esquecida do ovo, enquanto o texto se faz. No intervalo entre essas duas passagens, lemos:

Os ovos estalam na frigideira, e mergulhada no sonho preparo o café-da-manhã. Sem nenhum senso de realidade, grito pelas crianças que brotam das várias camas, arrastam cadeiras e comem, e o trabalho do dia amanhecido começa, gritado e rido e comido, clara e gema, alegria entre brigas, dia que é nosso sal e nós somos o sal do dia, viver é extremamente tolerável, viver ocupa e distrai, viver faz rir. E me faz rir no meu mistério (LE, p.63).

Vemos aqui o olhar da protagonista surpreendendo o símbolo das coisas nas próprias coisas, pois a linguagem que alude ao modo como o instante é percebido por esta mãe que prepara o café dos filhos tem um tom de magia que transforma o instante em uma cena de celebração. Nesse instante a protagonista também faz referência a seu mistério: "O meu mistério é que eu ser apenas um meio, e não um fim, tem-me dado a mais maliciosa das liberdades: não sou boba e aproveito. Inclusive, faço um mal aos outros que, francamente. O falso emprego que me deram para disfarçar a minha verdadeira função $[\ldots . .$.$] (p.64).$

A galinha "tonta, desocupada e míope", que "com o coração batendo, com o coração batendo tanto" não reconhece o ovo, assemelha-se à protagonista que novamente esquecida do ovo, pensa:

Já me foi dado muito; isto, por exemplo: uma vez ou outra, com o coração batendo pelo privilégio, eu pelo menos sei que não estou reconhecendo! Com o 
coração batendo de emoção, eu pelo menos não compreendo! Com o coração batendo de confiança, eu pelo menos não sei (LF, p.65).

Não saber é a condição necessária à galinha e à personagem, que termina a narrativa com esperança de mais uma vez voltar a ver o ovo deslocando-se no espaço. Não saber é um modo de ter: "O que não sei do ovo me dá o ovo propriamente dito - A Lua é habitada por ovo" (LF, p.56).

É a partir da elaboração do que ocorre na imaginação da protagonista ao olhar para um ovo no momento de preparar o café-da-manhã que, no espaço da escritura, o texto nos permite perceber o ver-imaginar desta personagem. No espaço de sua escritura, a narrativa imita o modo singular com que esta protagonista cria o ovo imaginado. Enquanto prepara o café-da-manhã, mergulhada em seus pensamentos, a personagem se mostra pensando o texto. Ao final do conto, ela encontra-se esperando que o ovo mais uma vez a escolha:

Por devoção ao ovo, eu o esqueci. Meu necessário esquecimento. Meu interesseiro esquecimento. Pois o ovo é um esquivo. Diante de minha adoração possessiva ele poderia retrair-se e nunca mais voltar. Mas se ele for esquecido. Se eu fizer o sacrifício de viver apenas a minha vida e de esquecê-lo. Se o ovo for impossível. Então - livre, delicado, sem mensagem nenhuma para mim - talvez uma vez ele se locomova do espaço até esta janela que desde sempre deixei aberta. E de madrugada baixe no nosso edifício. Sereno até a cozinha. Iluminando-a de minha palidez (LE, p.66).

A aproximação entre a galinha como um estado e a protagonista em seu momento atual se dá por repetição, algumas coisas ditas sobre a galinha são repetidas sobre a protagonista. A galinha "continua sendo redesenhada". Como observou Regina Pontieri (2001, p.220), o ovo e a galinha, enquanto seres de linguagem, "são corpo e significante de significados cambiantes". Esta dona-de-casa possui um falso emprego para disfarçar sua verdadeira função.

Em seu depoimento ao MIS, sobre os bichos, Clarice Lispector informou:

Quando eu era pequena, eu olhava muito para uma galinha, por muito tempo, e sabia imitar o bicar do milho, imitar quando estava com doença e isso sempre me 
impressionou tremendamente. Aliás, eu sou muito ligada a bichos, tremendamente. A vida de uma galinha é oca... uma galinha é oca!(OE, p.162)

Em sua vida, a galinha foi diretamente uma escolhida, na ficção também. Em Perto do coração selvagem, a narrativa começa com Joana-criança ouvindo os sons do mundo e dirigindo o olhar para "o grande mundo das galinhas-que-não-sabiam-queiam-morrer". No final do primeiro capítulo, o pensamento do pai da menina encerra-se em uma pergunta: "Anda tão solta a criança, tão magrinha e precoce... Respira apressado, balança a cabeça. Um ovinho, é isso, um ovinho vivo. O que vai ser de Joana?". Após a morte do pai, a menina passa a viver com sua tia. Na nova moradia, ela imagina: "Depois brincaria no quintal, onde havia paus e garrafas. Mas sobretudo aquele galinheiro velho sem galinhas [...]. O galinheiro tinha grades e tudo, seria a casa dela". Como o cavalo, o figurativo de um inominável, o ovo e a galinha são palavras que, presentes em diferentes contextos, engendram significados sempre dependentes da disposição singular das palavras e frases dos textos. A palavra pode ser pensada como uma nota musical, elemento mínimo do som, usada em infinitas possibilidades. Se concluirmos, com isso, que "tudo é um", não poderemos nos explicar sem voltarmos a cada texto individualmente e seus respectivos arranjos, nos quais essas palavras possuem significados cambiantes porque possuir este caráter é um aspecto constitutivo do estilo da escritora Clarice Lispector.

No conto, o emprego da protagonista está relacionado à feitura do ovo:

o falso emprego que me deram para disfarçar a minha verdadeira função, pois aproveito o falso emprego e dele faço o meu verdadeiro; inclusive o dinheiro que me dão como diária para facilitar minha vida de modo que o ovo se faça [...]. A isso tudo chamo ter a necessária modéstia de viver. E também o tempo que me deram, e que nos dão apenas para que no ócio honrado o ovo se faça, pois tenho usado esse tempo para prazeres ilícitos, inteiramente esquecida do ovo. Esta é a minha simplicidade (Ibid, p.64).

Nos anos 1950, Clarice Lispector vivia fora do Brasil e visitou o país de férias. Simeão Leal, responsável pela publicação do primeiro volume de contos da escritora, encomendou-lhe mais alguns contos com pagamento antecipado. Esta passagem de " $\mathrm{O}$ 
ovo e a galinha" pode ter relação com o trabalho de encomenda que comumente editores fazem aos escritores.

Entre a necessária modéstia de viver, preparando o ovo para o café-da-manhã, e o necessário esquecimento, absorta em seus pensamentos, o olhar da protagonista se volta para as crianças ao redor da mesa da cozinha. A linguagem que alude a este instante de vida doméstica é bela, e nos faz pensar nas seguintes palavras da escritora presentes no texto "Literatura e magia", referido no início deste trabalho: "o que vive e que chamamos de "natural', é em última instância, sobrenatural".

Sobre a realidade e o sonho na arte, Kandinsky (2000, p.243-4), na coletânea de ensaios "O futuro da pintura", escritos entre 1925 e 1943, também presente em Do espiritual na arte, em relação ao pintor, escreveu: “O pintor 'nutre-se' de impressões exteriores (vida exterior), transforma-as em sua alma (vida interior), a realidade e o sonho! Sem o saber. O resultado é uma obra".

Ainda sobre o sonho, o crítico Marcel Raymond (1997, p.41) fez a seguinte consideração: "parece que o espírito humano, no sonho, no devaneio ou mesmo durante a vigília, é dotado de um poder de criação autônomo, que imagina livremente fábulas, figuras, imagens, nas quais se projeta a afetividade profunda do eu". A protagonista do conto conhece a importância do sonho para que o ovo se faça, pois ressalta: "as galinhas prejudiciais ao ovo são aquelas que são um 'eu' sem trégua”.

No início do conto, apenas quando "ver o ovo é impossível”, ou seja, quando esqueceu o ovo como alimento, a protagonista pensa o ovo: "O ovo é supersensível", "O ovo é uma coisa suspensa", "O ovo é uma exteriorização", até que, considera:

Com o tempo, o ovo se tornou um ovo de galinha. Não o é. Mas, adotado, usa-lhe o sobrenome. - Deve-se dizer 'ovo da galinha'. Se se disser apenas 'ovo', esgotase o assunto, e o mundo fica nu. Em relação ao ovo, o perigo é que se descubra o que se poderia chamar de beleza. A veracidade do ovo não é verossímel. Se descobrirem, podem querer obrigá-lo a se tornar retangular. O perigo não é para o ovo, ele não se tornaria retangular. (Nossa garantia é que ele não pode: não pode é a grande força do ovo: sua grandiosidade vem da grandeza de não poder, que se erradia como um não querer.) Mas quem lutasse para torná-lo retangular estaria perdendo a própria vida. O ovo nos põe, portanto, em perigo. Nossa vantagem é que o ovo é invisível. E quanto aos iniciados, os iniciados disfarçam o ovo (LE, p. 58). 
O ovo tem a forma de uma oval vertical. Há uma simbologia desta forma que podemos discutir observando o estudo de Rudolf Arnheim (2001, p.124) sobre a composição nas artes visuais, em $O$ poder do centro. A forma oval, para Arnheim, comparada com o círculo, "compensa a perda de simetria cêntrica com um aumento de tensão". Porém, à medida que a elipse se torna mais longa e achatada, adquire as características do rectângulo", formato que tem capacidade para representar solidamente a existência neste mundo.

Pensamos que a personagem deste conto surpreende o símbolo das coisas nas próprias coisas ao percebermos que ela sabe que nem mesmo o ovo visto é uma forma regular.

Em outra passagem de "O ovo e a galinha" em que a protagonista declara: " - Só quem visse o mundo veria o ovo. Como o mundo, o ovo é óbvio". Ao invés de concordar com Descartes, "Penso, logo existo", considera: "Existo, logo sei". Mais à frente, também informa:

Faço parte da maçonaria dos que viram uma vez o ovo e o renegaram como forma de protegê-lo. Somos os que se abstêm de destruir, e nisso se consomem. Nós, agentes disfarçados e distribuídos pelas funções menos reveladoras, nós às vezes nos reconhecemos. A um certo modo de olhar, a um jeito de dar a mão, nós nos reconhecemos e a isto chamamos de amor (Ibid, p.61).

Em "Escrever, humildade, técnica", a escritora nos fez ver que, na concepção, algo sempre escapa. O ovo com o qual o artista trabalha "é invisível", mas, quando a personagem considera que "o ovo não se tornaria retangular", refletimos que qualquer realidade vista não constitui uma forma dada. O mundo que nos cerca não é uma realidade pronta e acabada, logo, os iniciados disfarçam o ovo porque sabem que, como observou Merleau-Ponty, em "A linguagem indireta", primeira versão do texto "A linguagem indireta e as vozes do silêncio", pertencente à obra inacabada $A$ prosa do mundo:

a permissão de não 'acabar' não é necessariamente preferência dada ao indivíduo sobre o mundo, ao não-significante sobre o significante, ela pode ser também o reconhecimento de uma maneira de comunicar que não passa pela evidência 
objetiva, de uma significação que não visa o objeto dado, mas o constitui e inaugura, e que não é prosaica porque desperta e reconvoca por inteiro nosso poder de exprimir e nosso poder de compreender (MERLEAU-PONTY, 2002, p. $82)$.

No capítulo "Conclusão: forma e conteúdo", do volume de ensaios $O$ vento e o moinho, sobre arte moderna e contemporânea, Rodrigo Naves (2007, p.508) considera que, se a grandeza da arte reside na renúncia à manipulação das coisas, "deve ela ter origem num tipo de percepção que renuncie ao controle e à dominação". Esta grandeza parece um aspecto especialmente caro ao artista moderno. O amor referido pela personagem do conto clariciano é dessa ordem:

Amor é quando é concedido participar um pouco mais. Poucos querem o amor, porque o amor é a grande desilusão de tudo o mais. E poucos suportam perder todas as outras ilusões. Há os que se voluntariam para o amor, pensando que o amor enriquece a vida pessoal. É o contrário: amor é finalmente a pobreza. Amor é não ter. Inclusive amor é a desilusão do que se pensava que era amor. E não é prêmio, por isso não envaidece, amor não é prêmio, é uma condição concedida exclusivamente para aqueles que, sem ele, corromperiam o ovo com a dor pessoal. Isso não faz do amor uma exceção honrosa; ele é exatamente concedido aos maus agentes, àqueles que atrapalhariam tudo se não lhes fosse permitido adivinhar vagamente (LE, p.62).

Ortega y Gasset (2005, p.64), ao destacar que "a tendência natural nos leva a crer que a realidade é o que pensamos dela", considerou que, se pelo contrário, "virarmo-nos de costas para a suposta realidade", tomando as idéias pelo que elas são, ou seja, esquemas subjetivos, "e as fizermos viver como tais", conseguiremos "fazê-las viver em sua irrealidade mesma". Estaremos realizando "o irreal enquanto irreal”. Há mais amor nisso do que na manipulação da idéia como realidade. Os narradores claricianos que freqüentemente revelam-nos não saber contar, evitam aprisionar as coisas com as palavras e são como os artistas modernos que conseguem fazer viver a irrealidade mesma.

Alberto Tassinari (2004, p. 147), realizando um esboço de leitura do texto "A dúvida de Cézanne", de Merleau-Ponty, escreveu que a percepção originária, aquela que 
“olha as coisas como que pela primeira vez", para o filósofo francês, já é expressão, sendo ela que Cézanne busca e pinta, podendo acontecer a qualquer pessoa, mas "se a expresso novamente, haverá duas expressividades em jogo, a expressividade do mundo e a das linguagens expressivas, seja a linguagem da pintura, a da literatura ou de outra arte” (p.148). Clarice Lispector sabe que o artista não é um inocente. Viu o mundo e se esforça para esquecê-lo, tornar-se inocente. Em "O ovo e a galinha", a personagem vê o ovo e o esquece, olhando-o como se fosse pela primeira vez. A linguagem está estruturada de modo a que esta percepção originária possa ser visível novamente por quem lê o texto. 


\section{CONSIDERAÇÕES FINAIS}

Nas narrativas de Clarice Lispector, o espaço ambiente não é uma realidade dada a priori, mas, muitas vezes, sensação experimentada no plano da consciência de suas personagens. A linguagem não tem por fim representar o espaço, mas, como nos alertou João Adolfo Hansen, e como tentamos mostrar ao longo das leituras dos textos, figurar atos da sensação. Permanece a figuração, mas a enunciação tem mais importância do que o enunciado porque a linguagem não é um vidro transparente de onde surge o sentido, ela própria vibra, tem som, ritmo, textura, seu sentido é imanente, e será preciso perceber este aspecto da linguagem para nos darmos conta de que o texto não representa simplesmente, ele faz mais do que isso: ele faz ver, ouvir, sentir algo mais que fica de fora da representação, e que nós leitores sentimos como a "Figura multissensível" de que falou Deleuze a respeito da pintura da Francis Bacon, e que aqui chamamos de "objeto gritante".

Ao observarmos o espaço da escritura clariciana como um espaço em obra espaço do fazer onde o feito se mostra ainda se fazendo - passamos a acompanhar mais de perto o trabalho de seus narradores que escrevem, pensam, narram, contam, imaginam textos, desvelando a narrativa ao expor sinais do fazer que apontam caminhos para a leitura da obra.

Em uma passagem de $A$ maçã no escuro (1961), a personagem Martim, após pensar no quanto somos suscetíveis à imitação, observando, por exemplo, que milhões de homens copiam com enorme esforço a idéia que se faz de homem, ressalta:

Mas tão distantes estamos pela imitação que aquilo que ouvimos nos vem tão sem som como se fosse uma visão que fosse tão invisível como se estivesse nas trevas que estas são tão compactas que mãos são inúteis. Porque mesmo a compreensão, a pessoa imitava. A compreensão que nunca fora feita senão da linguagem alheia e de palavras (ME, p.34).

Compreendemos que a narrativa de Clarice Lispector não representa pessoas, coisas, acontecimentos, simplesmente. No entanto, nossos sentidos, suscetíveis de se deixarem determinar pelos hábitos intelectuais cômodos ao espírito, diante do vidro e do jardim, podem ter ido direto ao jardim, à representação, e deixado de, ainda na figuração, ouvir, ver, sentir, enfim, perceber a imanência da linguagem, ou, ainda, 
deixado de observar a segunda função dos textos claricianos - a exposição - e não ter percebido que seus narradores "falam" da escritura. Esperamos que isso não tenha acontecido com muita freqüência, pois, se assim o fizemos, deixamos de perceber que o texto da escritora, como um quadro de René Magrite, nos convida a ver que, na arte, "une pipe", “Ceci n'est pas une pipe”.

Esperamos ter demonstrado que embora a relação da narrativa clariciana com as outras artes se mostre nos textos dos anos 1940 e 1950 (Clarice Lispector, como outros escritores modernos, produz obras que são o equivalente literário de uma sensibilidade moderna de ver, ouvir, sentir, experimentar o mundo), é inegável que, a partir dos anos 1960, as raízes entre literatura e outras artes se dão a ver mais explicitamente, sobretudo no "Fundo de gaveta" da obra A legião estrangeira que, juntamente com outros textos, constituirá o Objeto gritante, finalmente publicado como Água viva.

Quanto à observação de que Perto do coração selvagem contém, embrionariamente, tudo o que de marcante viria a singularizar a obra da escritora, devemos pensar em termos de "tudo é um": Clarice trabalha com a consciência de que, no percurso entre a idéia e a coisa, há um silêncio impossível de ser rompido por meio da representação, daí, de um lado figurar atos da sensação e, de outro, desvelar a figuração como trabalho do escritor (os narradores). Esses dois aspectos e outros, como a visão consistindo no ato de surpreender o símbolo das coisas nas próprias coisas e a obra inacabada, estavam presentes no primeiro romance e continuam presentes em outras obras. Apesar disso, cada texto de Clarice Lispector, embora iluminado por Perto do coração selvagem, traz novas experiências com a linguagem literária para o leitor. No "tudo é um" da obra clariciana, o primeiro romance pode ser visto como um "ovinho vivo" do qual sairiam outros que iluminaram outros, e assim, sucessivamente, como já dissemos, nunca se dando como representação completa.

Na palestra de 1963, sobre literatura de vanguarda, Clarice Lispector explicitava que o fundo-forma, a coisa propriamente dita, subsistia ao que se pode dizer dela. $\mathrm{O}$ tema "literatura e outras artes" na obra da escritora deve ser pesquisado por outros estudiosos a par de outras metodologias, mas, a obra, como coisa viva, continuará suscitando pensamentos, sons, imagens, silêncios etc. 


\section{REFERÊNCIA BIBLIOGRÁFICA}

\section{Obras da autora consultadas (ordem cronológica da primeira publicação)}

LISPECTOR, Clarice. Perto do coração selvagem. Rio de Janeiro: Rocco, 1997. (1 $1^{\mathrm{a}}$ ed. A Noite, 1943).

. O lustre. Rio de Janeiro: Rocco, 1999. (1ª ed. Agir, 1946).

. A cidade sitiada. Rio de Janeiro: Rocco, 1998. (1 ${ }^{\text {a }}$ ed. A Noite, 1949).

. Alguns contos, Rio de Janeiro: Ministério da Educação e Saúde, 1952.

. Laços de Família. São Paulo: Francisco Alves, 1960.

. A maçã no escuro. Rio de Janeiro: Rocco, 1998. (1 $1^{\mathrm{a}}$ ed. Francisco Alves, 1961).

. A paixão segundo G.H. Rio de Janeiro: Rocco, 1997. (1ª ed. Do Autor, 1964).

. A legião estrangeira. Rio de Janeiro: Editora do Autor, 1964.

. Uma aprendizagem ou o livro dos prazeres. Rio de Janeiro: Rocco, 1998. ( $1^{\mathrm{a}}$ ed.

Sabiá, 1969).

. Água Viva. Rio de Janeiro: Rocco, 1998. (1 ${ }^{\mathrm{a}}$ ed. Artenova, 1973).

. A via crucis do corpo. Rio de Janeiro: Rocco, 1998. (1 $1^{\mathrm{a}}$ ed. Artenova, 1974).

. Onde estivestes de noite? Rio de Janeiro: Rocco, 1999. (1 $1^{\mathrm{a}}$ ed. Artenova, 1974).

- Seleta de Clarice Lispector. Seleção e texto-montagem de Renato Cordeiro

Gomes. Estudo e notas de Amariles Guimarães Hill. Rio de Janeiro: José Olympio, 1976 ( $1^{\circ}$ ed. José Olympio, 1975).

. A hora da estrela. Rio de Janeiro: Record, 1984. (1ª ed. José Olympio, 1977).

. Um sopro de vida (Pulsações). Rio de Janeiro: Nova Fronteira, 1978.

. A paixão segundo G.H. (Edição crítica). 2 ed. São Paulo: Edusp, 1996.

. A bela e a fera. Rio de Janeiro: Rocco, 1999. (1 a ed. Nova Fronteira, 1979).

. De corpo inteiro. Rio de Janeiro: Rocco, 1999. (1ª ed. Artenova, 1975).

. Para não esquecer. Rio de Janeiro: Rocco, 1999. (1ª ed. Ática, 1978).

. A descoberta do mundo. Rio de Janeiro: Rocco, 1999. ( $1^{\mathrm{a}}$ ed. Nova Fronteira, 1984). 
. Outros escritos/Clarice Lispector. [Organizaçõo de Teresa Montero e Lícia Manzo]. Rio de Janeiro: Rocco, 2005.

. Entrevistas/Clarice Lispector. [Organização de Claire Williams; preparação de originais e notas biográficas de Teresa Montero]. Rio de Janeiro: Rocco, 2007.

\section{Obras de outros autores}

FLAUBERT, Gustave. Madame Bovary. In: Oeuvres. Paris: Bibliothèque de la Pléiade, 1936.

\section{Sobre a autora}

BUENO, Luís. "Guimarães, Clarice e antes". Teresa. Revista de Literatura Brasileira. Departamento de Letras Clássicas e Vernáculas. Faculdade de Filosofia Letras e Ciências Humanas. Universidade de São Paulo. São Paulo: Ed. 34, 2001.

CAMPOS, Haroldo de. "Estilística miramarina". In: Metalinguagem e outras metas: ensaios de teoria e crítica literária. São Paulo: Perspectiva, 2004.

CANDIDO, Antonio. "No raiar de Clarice Lispector". Vários escritos. São Paulo: Duas Cidades, 1970.

CHEREM. Lúcia Peixoto. Um olhar estrangeiro sobre a obra de Clarice Lispectorleitura e recepção da autora na França e no Canadá (Quebec). Tese de doutorado apresentada à Faculdade de Filosofia, Letras e Ciências Humanas da Universidade de São Paulo, 2003.

FERREIRA, Teresa Cristina Montero. Eu sou uma pergunta: uma biografia de Clarice Lispector. Rio de Janeiro: Rocco, 1999.

FRANCO JUNIOR, Arnaldo. Mau gosto e kitsch nas obras de Clarice Lispector e Dalton Trevisan. Tese de doutorado apresentada à Faculdade de Filosofia, Letras e Ciências Humanas da Universidade de São Paulo, 1999.

GOTLIB, Nádia Battella. Clarice Lispector: uma vida que se conta. São Paulo: Ática, 1995.

HELENA, Lúcia. "A vocação para o abismo: errância e labilidade em Clarice Lispector". Revista Brasileira de Literatura Comparada. v. 5. Rio de Janeiro, 2000.

HILL, Amariles Guimarães. "A experiência de existir narrando". In: LISPECTOR, Clarice. Seleta. 2 ed. Rio de Janeiro. José Olympio, 1976.

HOLANDA, Sérgio Buarque de. "Tema e técnica". Remate de Males. n. 9. Campinas: Unicamp, 1989.

IANNACE, Ricardo. Retratos em Clarice Lispector: literatura, pintura e fotografia. Tese de doutorado apresentada à Faculdade de Filosofia, Letras e Ciências Humanas da Universidade de São Paulo, 2004. 
JACINTHO, Valéria Franco. Cartas a Clarice Lispector. Correspondência passiva da escritora depositada na Fundação Casa de Rui Barbosa. Dissertação de mestrado apresentada à Faculdade de Filosofia, Letras e Ciências Humanas da Universidade de São Paulo, 1997.

LIMA, Luiz Costa. "Clarice Lispector". In: COUTINHO, Afrânio (dir). A literatura no Brasil. v. 5. 2ed. Rio de Janeiro:Editora Sul Americana, 1970.

LINS, Álvaro. "A experiência incompleta: Clarice Lispector". In: Os mortos de sobrecasaca: obras, autores e problemas da literatura brasileira. (Ensaios e estudos 1940-1969). Rio de Janeiro: Civilização Brasileira, 1963.

LUCAS, Fábio. "O conto no Brasil Moderno". In: PROENÇA FILHO, Domício (Org.). O livro do seminário: ensaios. São Paulo: L. R. Editores, 1983.

MILLIET, Sérgio. Diário crítico (1944). v. 2. São Paulo: Brasiliense, 1945.

MOISÉS, Carlos Felipe. "Clarice Lispector: ficção em crise". Remate de Males. n. 9. Campinas: Unicamp, 1989.

NUNES, Benedito. "Clarice Lispector ou o naufrágio da introspecção". Remate de Males. n. 9. Campinas: Unicamp, 1989.

NUNES, Benedito. O dorso do tigre. São Paulo: Perspectiva, 1969.

NUNES, Benedito. "Nota filológica”. In: LISPECTOR, Clarice. A paixão segundo G.H. (Edição crítica). 2 ed. São Paulo: Edusp, 1996.

NUNES, Benedito. O drama da linguagem: uma leitura de Clarice Lispector. São Paulo: Ática, 1989.

PESSANHA, José Américo Motta. "Clarice Lispector: o itinerário da paixão". In: LISPECTOR, Clarice. A paixão segundo G.H. (Edição crítica). 2 ed. São Paulo: Edusp, 1996.

PONTIERI, Regina. Clarice Lispector: uma poética do olhar. São Paulo: Ateliê Editorial, 2001.

ROSENBAUM, Yudith. Metamorfoses do mal: uma leitura de Clarice Lispector. São Paulo: Edusp, 1999 (Ensaios de cultura 17).

SÁ, Olga de. A escritura de Clarice Lispector. Petrópolis: Vozes; Lorena: Faculdades Integradas Teresa D’Avila, 1979.

SABINO, Fernando. Cartas perto do coração: Fernando Sabino e Clarice Lispector. Rio de Janeiro: Record, 2001. 
SANT'ANNA, Affonso Romano de. "Laços de família e Legião estrangeira". In: Análise estrutural de romances brasileiros. Petrópolis: Vozes, 1974.

SANTOS, Roberto Corrêa dos. "Percepção e sistemas cognitivos construtores de 'Menino a bico de pena'. Revista Tempo Brasileiro. Jan/mar, n. 128. Rio de Janeiro: Tempo Brasileiro, 1997.

SANTOS, Roberto Corrêa dos. Clarice Lispector. São Paulo: Atual, 1986.

SOUSA, Carlos Mendes. Clarice Lispector: figura da escrita. Braga: Universidade do Minho, Centro de Estudos Humanísticos, 2000. (Coleção Poliedro).

TEIXEIRA, César Mota. A poética do instante: uma leitura de Água Viva de Clarice Lispector. Dissertação de mestrado apresentada à Faculdade de Filosofia, Letras e Ciências Humanas da Universidade de São Paulo, 2001

VIANNA, Lúcia Helena. "O figurativo inominável: os quadros de Clarice Lispector (ou restos de ficção)". In: ZILBERMAN, Regina et al. Clarice Lispector: a narração do indizível. Porto Alegre: Artes e Ofício, EDIPUC, Instituto Judaico Marc Chagall, 1998.

\section{Textos teóricos e críticos}

ADORNO, Theodor W. "Posição do narrador no romance contemporâneo". In: Notas de literatura I. Trad. Jorge de Almeida. São Paulo: Editora 34, 2003.

ARANTES, Otília Beatriz Fiori. Mário Pedrosa: itinerário crítico. São Paulo: Cosac Naify, 2004.

ARGAN, Giulio Carlo. "As fontes da arte moderna". Trad. Rodrigo Naves. Novos Estudos. São Paulo: Cebrap. n. 18. Set, 1987.

ARGAN, Giulio Carlo. A arte e a crítica de arte. Trad. Helena Gubernatis. 2 ed. Lisboa: Editorial Estampa, 1995.

ARGAN, Giulio Carlo. Arte moderna: do iluminismo aos movimentos contemporâneos. Trad. Denise Bottmann e Federico Carotti. São Paulo: Companhia das Letras, 1992.

ARNHEIM, Rudolf. $O$ poder do centro: um estudo da composição nas artes visuais. Trad. Maria de Elisa Costa. Lisboa: Edições 70, 2001.

AUERBACH, Erich. Mimesis - a representação da realidade na literatura ocidental. São Paulo: Perspectiva, 1971.

AYALA, Walmir. Dicionário de pintores brasileiros. v. 1. Rio de Janeiro: Spala, 1986.

BACHELARD, Gaston. A poética do devaneio. Trad. Antônio Pádua Danesi. São Paulo: Martins Fontes, 1988.

BAKHTIN, Mikail. A cultura popular na idade média e no renascimento. Trad. Yara 
Frateschi Vieira. 5 ed. São Paulo: Annablume, 2002.

BARBOSA, João Alexandre. "Literatura e sociedade do fim do século". In: Alguma crítica. São Paulo: Ateliê Editorial, 2002.

BARREIRA, Cecília. "O casamento e a família”. Metacrítica n.4. Lisboa: Universidade Lusófona de Humanidades e Tecnologias. mar. 2004.

BARTHES, Roland. Aula. Trad. Leyla Perrone-Moisés. São Paulo: Cultrix, 1996.

BARTHES, Roland. O neutro. Trad. Ivone Castelho Benedetti. São Paulo: Martins Fontes, 2003.

BEHNKE, Kerstin. “A crise da representação". Cadernos do mestrado/literatura. n. 10, Rio de Janeiro: UERJ, 1994.

BENJAMIN, Walter. "O surrealismo. O último instantâneo da inteligência européia”. In: Obras escolhidas. Magia e técnica; arte e política. Trad. Sérgio Paulo Rouanet. São Paulo: Brasiliense, 1994.

BERGSON, Henri. Matéria e memória: ensaios sobre a relação do corpo com o espírito. Trad. Paulo Neves. São Paulo: Martins Fontes, 1999.

BOSI, Alfredo. "Fenomenologia do Olhar". In. NOVAES, Adauto et al. O olhar. São Paulo: Companhia das Letras, 1988.

BOSI, Alfredo. História concisa da literatura brasileira. São Paulo: Cultrix, 1994.

BOSI, Alfredo. Reflexões sobre a arte. São Paulo: Ática, 2004.

BRETON, André. "Do simbolismo". In: A pintura. v. 7. Trad. Magnólia Costa. São Paulo: Editora 34, 2005.

BUTOR, Michel. "Joyce e o romance moderno". In: BUTOR, Michel et al. Joyce e o romance moderno. Trad. T. C. Netto. São Paulo: Documentos, 1969.

BUTOR, Michel. Repertório. Trad. Leyla Perrone-Moisés. São Paulo: Perspectiva, 1974.

CANDÉ, Roland. História universal da música. Trad. Eduardo Brandão. São Paulo: Martins Fontes, 1994.

CANDIDO, Antonio. "A literatura e a formação do homem” In: Textos de intervenção. Seleção apresentação e notas de Vinícius Dantas. São Paulo: Editora 34, 2002.

CANDIDO, Antonio. A educação pela noite e outros ensaios. 3 ed. São Paulo: Ática, 2003.

CANDIDO, Antonio. Literatura e sociedade: estudos de teoria e história literária. 7 ed. São Paulo: Nacional, 1985. 
CHAUI, Marilena. "Merleau-Ponty: obra de arte e filosofia". In: NOVAES, Adauto (Org.). Artepensamento. São Paulo: Companhia das Letras, 1994.

CHEVALIER, Jean, GHEERBRANT, Alain et al. Dicionário de simbolos. Trad. Vera da Costa e Silva et al. 20 ed. Rio de Janeiro: José Olympio, 2006.

CHIPP, Herschel Browning. Teorias da arte moderna. Trad. Waltensir Dutra et al. São Paulo: Martins Fontes, 1988.

CLÜVER, Claus. "Estudos interartes: conceitos, teorias, objetivos". Literatura $e$ sociedade. n. 2. São Paulo: Edusp, 1997.

DE MICHELI, Mário. As vanguardas artísticas. Trad. Píer Luigi Cabra. São Paulo: Martins Fontes, 2002.

DELEUZE, Gilles. Francis Bacon: Lógica de la sensación. Trad. Isidro Herrera. Madrid: Arena Libros, 2005.

DIDI-HUBERMAN, Georges. O que vemos, o que nos olha. Trad. Paulo Neves. São Paulo: Editora 34, 1998.

DOESER, Linda. The life and works of Klee. New York: Shootinh Star Press, 1995.

FAVARETTO, Celso. "Das novas figurações à arte conceitual". In: Tridimensionalidade/[Editor] Instituto Cultural Itaú. Apresentação de Ricardo Ribenboim. São Paulo: Instituto Cultural Itaú, 1997.

FRANCASTEL, Pierre. A realidade figurativa. Trad. Marly Amazonas Leite de Barros. São Paulo: Perspectiva, 1993.

FRANCASTEL, Pierre. Pintura e sociedade. Trad. Elcio Fernandes. São Paulo: Martins Fontes, 1990.

FREITAS, Artur. "Poéticas políticas: as artes plásticas entre o golpe de 64 e o AI-5". História: Questões e debates. n. 40, p.59-90. Curitiba: Editora de UFPR, 2004.

FRY, Roger. Visão e forma. Trad. Cláudio Marcondes. São Paulo: Cosac Naify, 2002.

GOMBRICH, E.H. História da arte. Trad. Álvaro Cabral. Rio de Janeiro: LTC, 1999.

GREENBERG, Clement. "A pintura moderna". In: BATTOCCK, Gregory (Org.) $A$ nova arte. 2 ed. São Paulo: Perspectiva, 1986.

GREENBERG, Clement. Arte e cultura: ensaios críticos. Trad. Otacílio Nunes. São Paulo: Ática, 1996.

GULLAR, Ferreira. Etapas da arte contemporânea: do cubismo à arte neoconcreta. Rio de Janeiro: Revan, 1999. 
HAUSER, Arnold. História social da literatura e da arte. Trad. Álvaro Cabral. São Paulo: Martins Fontes, 2003.

HOUAISS, Antônio, VILLAR, Mauro Salles. Dicionário Houaiss da língua portuguesa. Elaborado no Instituto Antônio Houaiss de Lexicografia e Banco de Dados da Língua Portuguesa. Rio de Janeiro: Objetiva, 2001.

HUNTER, Sam. "Picasso na guerra: Royan, 1940. Caderno de desenhos no 110, 1946". In: GLIMCHER, Arnold, GLIMCHER, MARC. Je suis lê cahier: os cadernos de Picasso. Trad. A. B. Pinheiro de Lemos. Rio de Janeiro: Record, 1986.

JOHNSON, Randal. "A dinâmica do campo literário brasileiro". Trad. Antônio Dimas. Revista USP. n. 26. São Paulo, jun/jul/ago, 1995.

KANDINSKY, Wassily. Do espiritual na arte. Trad. Álvaro Cabral e Antônio de Pádua Danesi. São Paulo: Martins Fontes, 2000.

KELLER, Heins. "Suíça”. Catálogo da I Bienal do Museu de Arte Moderna de São Paulo. 2 ed. São Paulo, 1951.

KLEE, Paul. Diários. Trad. João Azenha Jr. São Paulo: Martins Fontes, 1990.

KLEE, Paul. Sobre a arte moderna e outros ensaios. Trad. Pedro Süssekind. Rio de Janeiro: Jorge Zahar Editor, 2001.

LEITE, José Roberto Teixeira et al. "Os contemporâneos, Desenho industrial, Comunicação visual, Arte popular, Caricatura”. In: Arte no Brasil. v. 2. São Paulo: Abril Cultural, 1979.

LICHTENSTEIN, Jacqueline. "O paralelo das artes". In: A pintura. Vol. 7. Trad. Magnólia Costa. São Paulo: Editora 34, 2005.

LUKÁCS, Georg. Teoria do romance. Trad. José Marcos Mariani de Macedo. São Paulo: Editora 34, 2000.

LYOTARD, Jean-François. Dircurso, figura. Trad. Josep Elias e Cartola Hesse. Barcelona: Gustavo Gili, 1979.

MARTINS, Wilson. A crítica no Brasil. 3 ed. Rio de Janeiro: Francisco Alves, 2002. Vol. 2.

MERLEAU-PONTY, Maurice. "A linguagem indireta". In: A prosa do mundo. Trad. Paulo Neves. São Paulo: Cosac Naify, 2002.

MERLEAU-PONTY, Maurice. O espírito e o olho: seguido de A linguagem indireta e as vozes do silêncio e A dúvida de Cézanne. Trad. Paulo Neves e Maria Ermantina Galvão Gomes. São Paulo: Cosac Naify, 2004.

MOSER, Walter. "Estudos literários". Literatura e sociedade. n. 3. São Paulo: Edusp, 1998. 
NAVES, Rodrigo. A forma dificil: ensaios sobre a arte brasileira. São Paulo: Ática, 1996.

NAVES, Rodrigo. O vento e o moinho: ensaios sobre arte moderna e contemporânea. São Paulo: Companhia das Letras, 2007.

OITICICA, Hélio. "A transição da cor do quadro para o espaço e o sentido de construtividade". In: FERREIRA, Glória \& COTRIM, Cecília. Escritos de artistas: Anos 60/70. Rio de Janeiro: Jorge Zahar, 2006.

OLIVEIRA, Solange Ribeiro de. Literatura e música. São Paulo: Editora Perspectiva. 2002.

ORTEGA y GASSET, José. A desumanização da arte. Trad. Ricardo Araújo. 5 ed. São Paulo: Cortez, 2005.

OSTROWER, Fayga. “A construção do olhar". In: NOVAES, Adauto et al. O olhar. São Paulo: Companhia das Letras, 1988.

PANOFSKY, Erwin. A perspectiva como forma simbólica. Trad. Elisabete Nunes. Lisboa: Edições 70, 1993.

PARINAUD, André. "Por que sou escultor - entrevista de Alberto Giacometti a André Parinaud”. Trad. Célia Euvaldo. Novos Estudos. n. 34. São Paulo: Cebrap, nov. 1992.

PEDROSA, Mário. “Arte, necessidade vital”. In: Arte necessidade vital. Rio de Janeiro: Livraria Editora da Casa do Estudante do Brasil, 1949.

PEDROSA, Mário. Acadêmicos e modernos: textos escolhidos III. Otília Arantes (Org.). São Paulo: Edusp, 2004.

PEDROSA, Mário. Modernidade cá e lá: textos escolhidos IV. Otília Arantes (Org.). São Paulo: Edusp, 2000.

PERRONE-MOISÉS, Leyla. O novo romance francês. São Paulo: Buriti, 1966.

PONTUAL, Roberto. Arte/Brasil/Hoje: 50 anos depois. São Paulo: Collectio, 1973.

PONTUAL, Roberto. Dicionário das artes plásticas no Brasil. Rio de Janeiro: Civilização Brasileira, 1969.

PRAZ, Mário. Literatura e artes visuais. Trad. José Paulo Paes. São Paulo: Cultrix, 1982.

RAYMOND, Marcel. De Baudelaire ao surrealismo. Trad. Fúlvia M. L. Moretto e Guacira Marcondes Machado. São Paulo: Edusp, 1997.

READ, Herbert. A filosofia da arte moderna. Trad. José Maria Miranda. Portugal: Ulisseia, $\mathrm{s} / \mathrm{d}$. 
REGEL, Günther. "O fenômeno Paul Klee". In: KLEE, Paul. Sobre a arte moderna e outros ensaios. Trad. Pedro Süssekind. Rio de Janeiro: Jorge Zahar, 2001.

REIS, Paulo. Arte de vanguarda no Brasil. Rio de Janeiro: Jorge Zahar, 2006.

RICOEUR, Paul. “A questão do poder". In: História e verdade. Trad. F. A. Ribeiro. Rio de Janeiro: Forense, 1968.

RICOEUR, Paul. Tempo e narrativa. Trad. Maria Appenzeller. Campinas: São Paulo: 1995. (Tomo II).

ROSENFELD, Anatol. "Reflexões sobre o romance moderno". In: Texto/contexto I. São Paulo: Perspectiva, 1996.

ROSENFELD, Anatol. Prismas do teatro. São Paulo: Perspectiva, 1993.

SCHAPIRO, Meyer. A arte moderna. Séculos XIX e XX. Trad. Luiz Roberto Mendes Gonçalves. São Paulo: Edusp, 1996.

SCHWARZ, Roberto. “Cultura e política 1964-69”. In: O pai de família e outros ensaios. Rio de Janeiro: Paz e Terra, 1978.

SYLVESTER, David. Sobre arte moderna. Trad. Alexandre Morales. São Paulo: Cosac Naify, 2006.

TASSINARI, Alberto. "Quatro esboços de leitura". In: MERLEAU-PONTY, Maurice. O Olho e o espírito. Trad. Paulo Neves e Maria Ermantina Galvão Gomes. São Paulo: Cosac Naify, 2004.

TASSINARI, Alberto. O espaço moderno. São Paulo: Cosac Naify, 2001.

VALLIER, Dora. A arte abstrata. Trad. De João Marcos Lima. Lisboa: Edições 70, 1986.

WELLEK, René, WARREN, Austin. "Literatura e outras artes". In: Teoria da literatura. Trad. José Palla e Carmo. Lisboa: Europa-América, 1971.

WISNIK, José Miguel Soares. "Iluminações profanas, profetas, drogados". In. NOVAES, Adauto et al. O olhar. São Paulo: Companhia das Letras, 1988.

WISNIK, José Miguel Soares. $O$ som e o sentido: uma outra história das músicas. São Paulo: Companhia das Letras, 2002.

ZANINI, Walter. “Arte contemporânea”. In: História geral da arte no Brasil. v. 2. São Paulo: Instituto Walther Moreira Salles, 1983. 
ANEXO 1

Pag. 8 - 1.0 caderno - FOLHA DE S. PAULO (3.a edição) - 5.a-feira, 28 de julho de 1960 


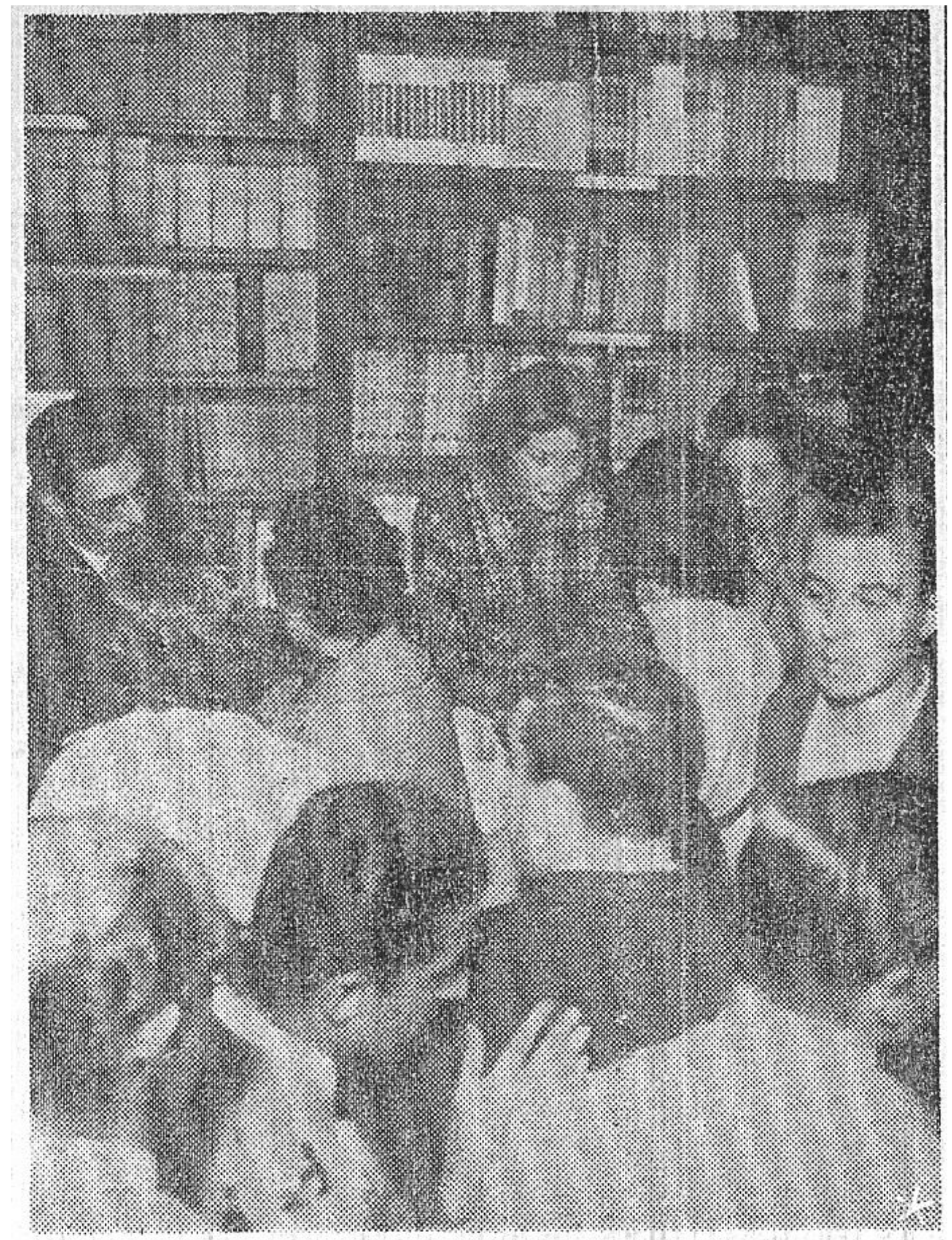

\section{《L.aços Ule Familia》 lançalo}

- Num coquetel na tivraria Francisco Alves, na tarde de ontem, foi lancado o livro de contos "Lacos de Famitia" da escritora Clarisse Lispector. No mesma ocasiäo foi inaugurada uma exposiçĭo die trabalinos de
Ciro Del Nero, autor da capat e das ilustrações do tivro. 0 coquetel de lancamento foi promoviou pela Editora Laços de Tramilia e pela revista" "Senhor". Na foto, a escritora Clarisse tispector quando aum tografave exiemplares the ser zivro.

ANEXO 2 

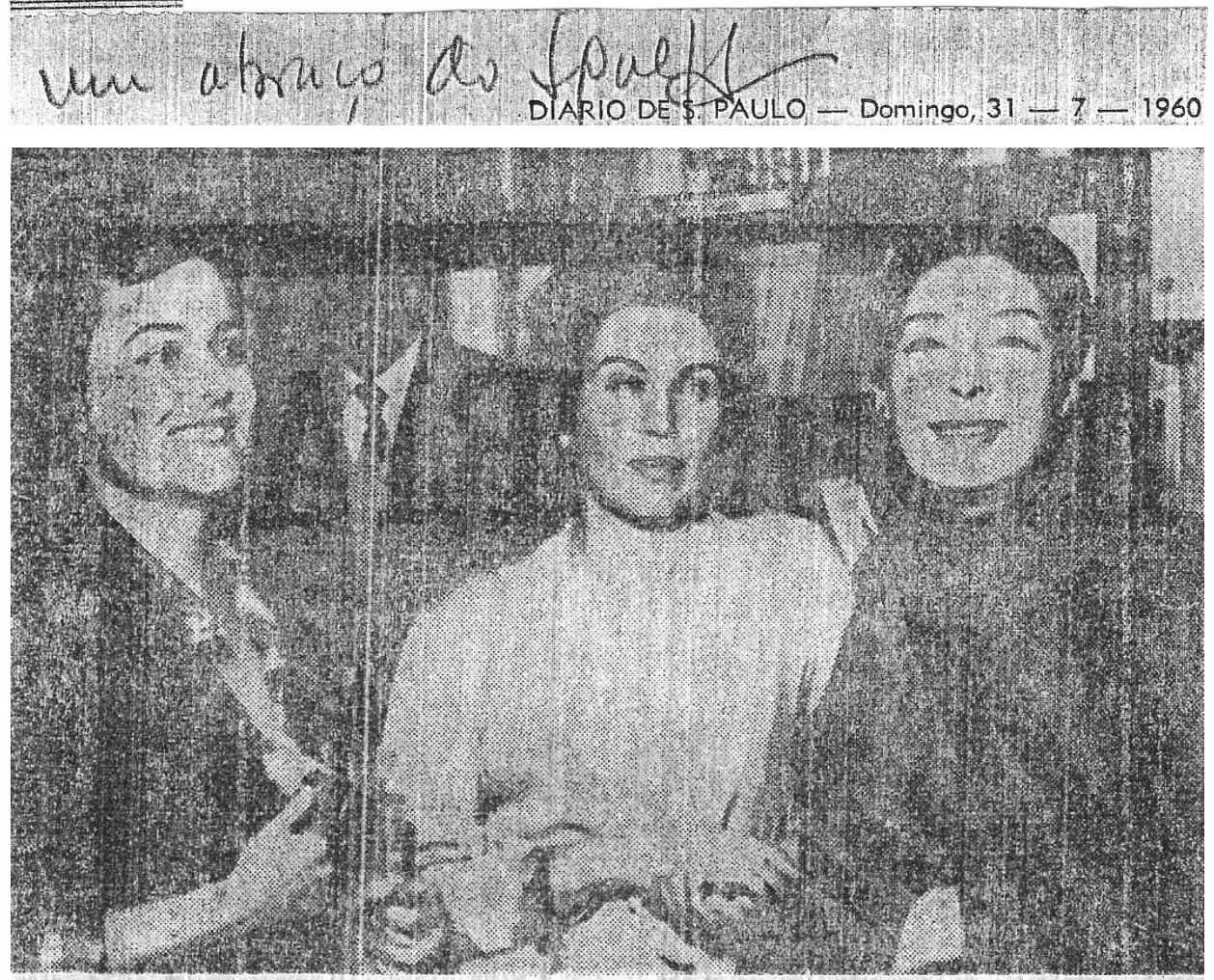

Donas Antunieta Dias de Morais, Lenita Miranda Figueiredo e Maria de Leurdes Teixeira

\section{PRESENCA DE CLARICE LIISPECTOR}

Fanhows sนa personalidade humana e literóxia se projeto refrss-

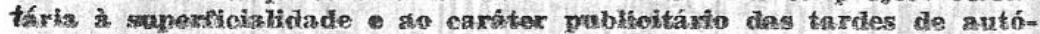
grufos, Clavios Tispector náo teva como evitar comparecer d Livra-

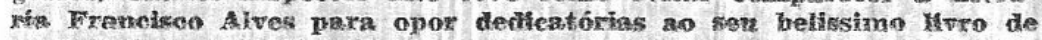
contos "Lacos de Família", com capa - tlustracáo magnifleas assimadiuas por Uyxo Del Nero.

Descie a sua estréia nas letras que uma mistério cercava a a hmirárel escritora. Átém de ocultar-se sob um pseudoninuo, passava a maior parte do tempo nos estrangeiro e quando se achava no Brasil, vivin aे margem cia vida literária, ausente das "igrejinhas", fora da orbita dos ciclos dos elegios mutuos. Fugindo à regra, sempre se fez conheeer unica e exclusivamente atiavés da sua obra. Sempre se impos ao conceito de criticos e leitores tão somente pelas qualidades excepcionais e inconfundiveis de seus romances "Perto do Coracão Selvagem", "O Lustre" e "Cidade Sitiada", e de seus contos publiearlos em revista e suplementos literíxios, muitos dos quais se enenntram reunidos no volume gora laneado pela Editora Francisco Alves.

Lewadas nâo apenas pelo desejo de conhocer pessoalmente ClaFíco Rispector, como também nela raxa oportunidade oủe se lhes oferecir de homenagear aquela que e, reconheoidamente, uma das mais legitimas, dos mais altios valores femininos da literatura brasileira. The vangurda, e de adquirix um exemplax die "Laços de Familia" com a. dedicntoria da autora, algumas clezenas de representantes do publico leitor, de escritores, poetas e artistas acorreram à livraria da Trua Libero Badaró, confraternizaram en torno da grande ficcionistas durante o cocktail oferecido pela editora e pela revista "Sr".

Foi das mais concorridas tardes de antografos dentre as pealizadas ultimamente em São Paulo. Contudo, é de lamentar sinceramente nño tenha sido poupado a Clarice Lispector sse genero de jromoçáo do móxitos tão discutiveis. (Texto de CurRISTINA - Fotos de GAONAl 


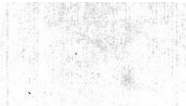

Sr. ${ }^{a}$ Flora Morgan Snell

pintora, figura quase sempre nas colunas sociais dos jornais e revistas, ora por motivo de exposiçóes, ora por motivo de viagem, ora por motivo de recepçỏes. Aliás, ela própria parece uma figura internacional, lembra boneca estrangeira. Era justo entrevistá-la.

O fotógrafo Marcos Vinício (que é também bom poeta) e eu fomos recebidos no ultra-suntuoso apartamento (Vieira Souto) por um mordomo devidamente fardadó.

Não reparei se usava luvas ou não. Ele, muito moço, parece imbuído de suas altas funçōes mas tem um olhar inocente. Lembrei-me de que nos livros policiais, especialmente de Agatha Christie, o assassino é yase sempre o mordomo. 0

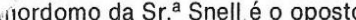
de um assassino: é um leve robot. Depois ouvimos o "boa-tarde" da Sr. ${ }^{a}$ Snell. Pelo que eu havia visto de suas pinturas vigorosas e de traços musculares eu imaginara uma voz de mezzo-soprano. Para a minha surpresa, a voz é de soprano lírica e o modo de se vestir é ultrafeminino. Durante

praticamente toda a entrevista năo parou de sorrir. Estava vestida de gaze desmaiadamente lilás, os lábios lilases, as faces lilases, e a sua cabeleira louríssima é muito muito alta. Ofereceu-nos gentilmente um café. Mas foi lacônica nas respostas.

- Sua pintura - disse-lhe eu lembra-me a pintura que um cultor faria. A senhora esculpiu?

- Minha pintura é considerada pintura de escultor

- Quando é que a senhora começou a pintar?

- Sempre pintei e desenhei.

- Em que países a senhora já fez exposiçöes?

- No mundo inteiro.

- Em que lugar do mundo a

senhora se sente mais compreendida?

- Como tenho colecionadores no. mundo inteiro, não há problemas em nenhum lugar.

- Desculpe a pergunta, que só faço para ter mais certezas: te dinheiro Ihe facilita maiores

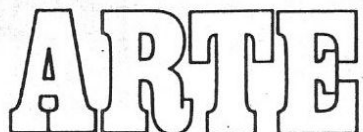

oportunidades de expor no exterior do que a qualquer pintor nosso?

- Ter dinheiro é uma desvantagem para o artista. Dinheiro é uma coisa a que certas pessoas dão importância. A liberdade está na criação.

- Com que pintores a senhora tem maior afinidade?

- Com nenhum. Sou muito individualista e minha pintura não se parece com nentiuma outra: Morgan Snell é Morgan Snell. - Estava longe de mim insinuar qualquer plágio ou seque influência; eu apenas me referia afinidade. Por exemplo, eu, que não sou pintora, tenho afinidade

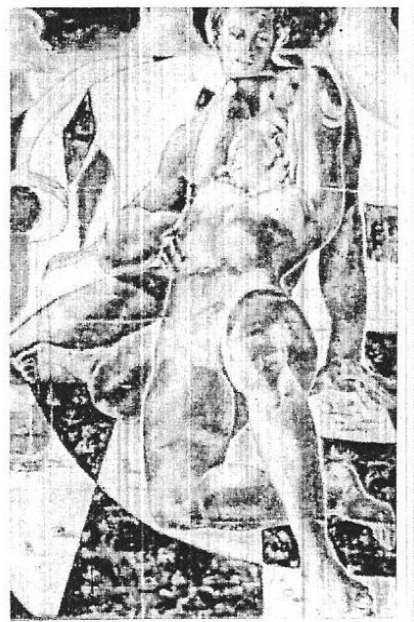

com Chagall. Mas não tem importancia. A senhora estudou pintura ou é uma autodidata?

- Sou inteiramente autodidata.

- Pelo que vejo, quando leio às vezes as colunas sociais, além da senhora ser muito festejada, viaja muito. Qual é o seu

verdadeiro domicílio?

(Gargalhada)

- Meus quadros é que viajam

muito! Eu estou no Rio ou em Paris

- Qual é o tipo de colecionador

que compra os seus quadros?

- Espero que sejam aqueles que amam a minha pintura.

- Quais sáo os críticos brasileiros que se ocuparam de sua obra?
- Nem me lembro mais. E quem se ocupa com minha obra sou eu mesma.

-Com "se ocupam" eu queria apenas dizer que "interpretam", "estudam", "analisam" seus quadros. Houve um mal-entendido, mas não tem importância, eu deveria ter sido mais clara. 0 quie é que a senhora jamais pintou e tem vontade de um dia pintar? - Tenho tanta inspiraçắo que precisaria de mais de mil anos para pintar.

- Qual é a classe social que sua pintura mais atinge?

- Todas.

Deu-se então por encerrada a entrevista, pois as respostas eram

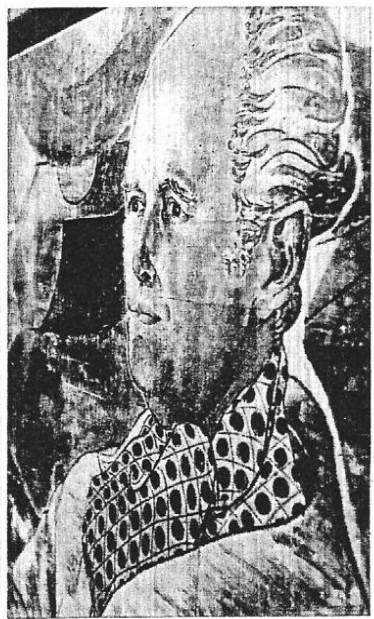

tảo sucintas (talvez por modéstia) que não me davam a chance de estabelecer o que se chama de diálogo caloroso... Eu já conheci muitos artistas - pintores,

escultores, poetas, músicos, romancistas - e posso afirmar que ar a Snell foi a única a me transmitir tal absoluta segurança em si mesma, sem sinal das dúvidas que ocorrem em quem cria arte. Deve ser muito gratificante ter tanta confiança na própria obra.

$\square$

Texto de Clarice Lispector

Fotos de Marcos Vinício
"Meus quadros saà pintura-de pintura-de" diz Morgan diz Morgan Snell. As reproduçōes abaixo confirmam o juízo da crítica. A artista domina plenamente recursos como o claro-escuro, deformaçóes perspectivas $e$ o desenho anatômico.

क?

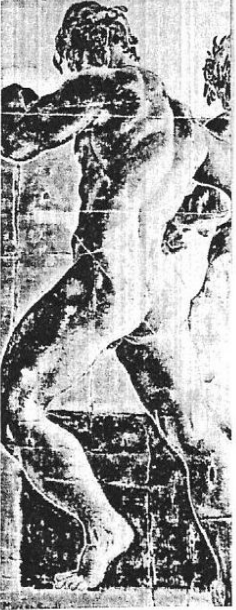

No estranho relacionamento entre autores e respectivas obras, o caso de Snell é dos mais interessantes. Enquanto seus quadros são vigorosos, musculares e enérgicos, ela é gentil, ultrafeminina e extremamente sorridente.

\section{FLORA MORGAN SNELL, A PINTORA BRASILEIRA MAIS CONHECIDA NA EUROPA, E AMAVEL E FEMININA COMO UMA BONECA DE LUXO. MAS OS SEUS QUADROS SÃO VARONIS, ESCULTURAIS E CHEIOS DE UM VIGOR QUE EMPOLGA O PÚBLICO}

